LA--10256-MS

UG-11

DE85 016209

Issued: June 1985

\title{
Radiological Survey and Evaluation of the Fallout Area from the Trinity Test: \\ Chupadera Mesa and White Sands Missile Range, New Mexico
}

Wayne R. Hansen

John C. Rodgers DISCLAIMER
This report was prepared as an account of work sponsored by an agency of the United States
Government. Neither the United States Government nor any agency thereof, nor a nyy of their
employes,s makes any warranty, express or implied, or assumes any legal liability or responsi-
bility for the accuracy, completeness, or usefulness of any information, apparatus, product, or
process disclosed, or represents that its use would not infringe privately owned rights. Refer-
ence herein to any specific commercial product, process, or service by trade name, trademark, DISCLAIMER
This report was prepared as an account of work sponsored by an agency of the United States
Government. Neither the United States Government nor any agency thereof, nor any of their
employes, makes any warranty, express or implied, or assumes any legal liability or responsi-
bility for the accuracy, completeness, or usefulness of any information, apparatus, product, or
process disclosed, or represents that its use would not infringe privately owned rights. Refer-
ence herein to any specific commercial product, process, or service by trade name, trademark, DISCLAIMER
This report was prepared as an account of work sponsored by an agency of the United States
Government. Neither the United States Government nor any agency thereof, nor any of their
employes, makes any warranty, express or implied, or assumes any legal liability or responsi-
bility for the accuracy, completeness, or usefulness of any information, apparatus, product, or
process disclosed, or represents that its use would not infringe privately owned rights. Refer-
ence herein to any specific commercial product, process, or service by trade name, trademark, DISCLAIMER
This report was prepared as an account of work sponsored by an agency of the United States
Government. Neither the United States Government nor any agency thereof, nor any of their
employes, makes any warranty, express or implied, or assumes any legal liability or responsi-
bility for the accuracy, completeness, or usefulness of any information, apparatus, product, or
process disclosed, or represents that its use would not infringe privately owned rights. Refer-
ence herein to any specific commercial product, process, or service by trade name, trademark, DISCLAIMER
This report was prepared as an account of work sponsored by an agency of the United States
Government. Neither the United States Government nor any agency thereof, nor any of their
employes, makes any warranty, express or implied, or assumes any legal liability or responsi-
bility for the accuracy, completeness, or usefulness of any information, apparatus, product, or
process disclosed, or represents that its use would not infringe privately owned rights. Refer-
ence herein to any specific commercial product, process, or service by trade name, trademark, DISCLAIMER
This report was prepared as an account of work sponsored by an agency of the United States
Government. Neither the United States Government nor any agency thereof, nor any of their
employes, makes any warranty, express or implied, or assumes any legal liability or responsi-
bility for the accuracy, completeness, or usefulness of any information, apparatus, product, or
process disclosed, or represents that its use would not infringe privately owned rights. Refer-
ence herein to any specific commercial product, process, or service by trade name, trademark, 


\section{CONTENTS}

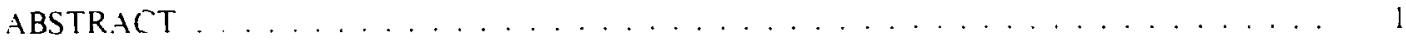

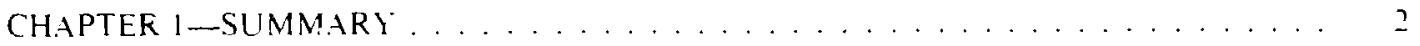

CHAPTER 2-INTRODLCTION AND BACKGIROI IND ........... 5

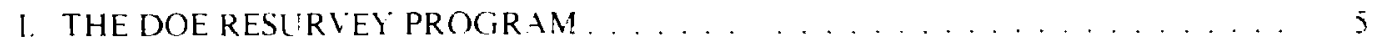

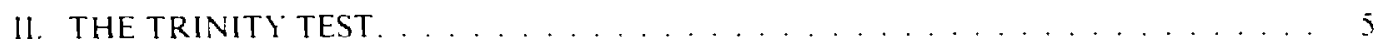

III. THE TRINITY FALLOUT ZONE ................. 5

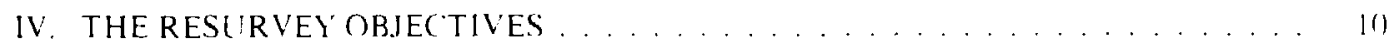

CHAPTER $3-M E T H O D S$ AND $I P P R O A C H \ldots \ldots \ldots \ldots \ldots$

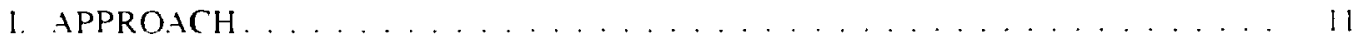

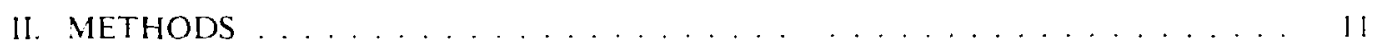

A. In Situ Measurenent. . . . . . . . . . . . . . . . . . . . . . II

B. Sampling and Analysis............................. 12

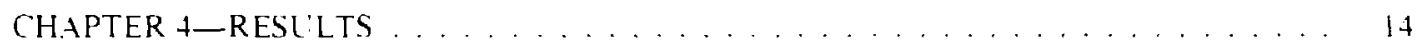

1. TOTAL AREA. . . . . . . . . . . . . . . . . . . . 14

A. Trinity Data tnalysis: "Cs in Soil . . . . . . . . . . . . . . . . . . . 14

B. Trinity Data Analysis: ${ }^{2 w}{ }^{2+1}$ Pu in Sorl . . . . . . . . . . . . . . . 18

C. Other Fission and Activation Pronducts ın Soils . . . . . . . . . . . . . . . . 20

D. Vatural Radioactivity in Soils . . . . . . . . . . . . . . . . . . . . 23

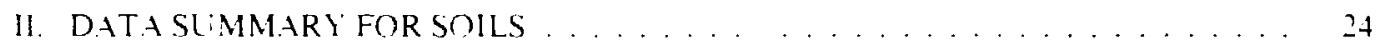

t. Plutonium in Sols . . . . . . . . . . . . . . . . . . . . 24

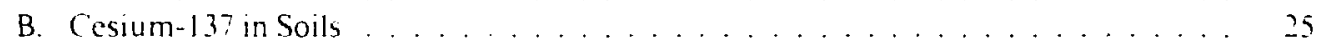

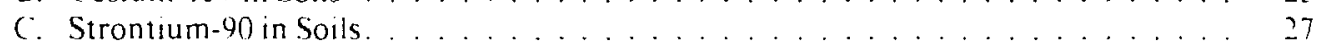

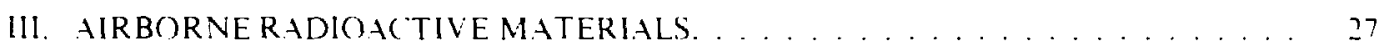

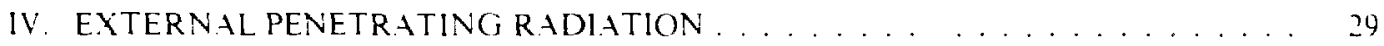

CHAPTER 5-POTENTIAL DOSE EVAILATION AND INTEPPRETATION. . . . . . 40

1. B.ASES OF DOSE ESTIMATES AND (COMPARISONS . . . . . . . . . . . . . 40)

II. POTENTIAL DOSES FROM THE CURRENT CONDITIONS IN THE TRINITY TEST FALLOUT DEPOSITION AREAS . . . . . . . . . . . . . 43

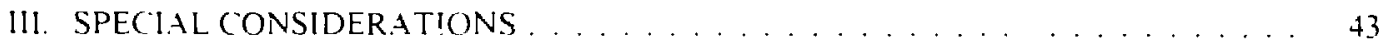




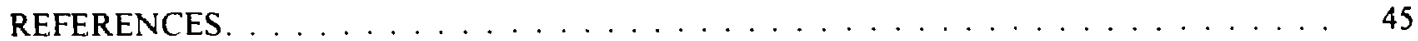

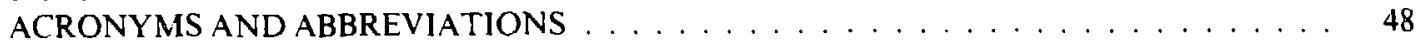

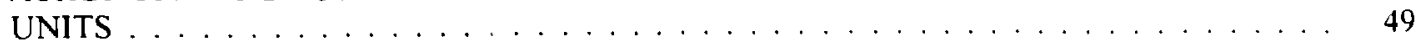

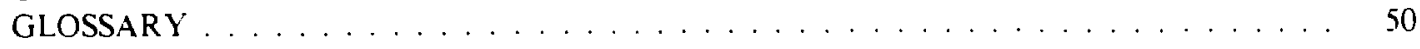

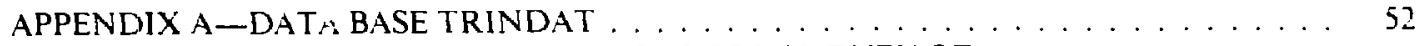

APPENDIX B-LOG OF FIELD OPERATIONS FOR SUR VEY OF

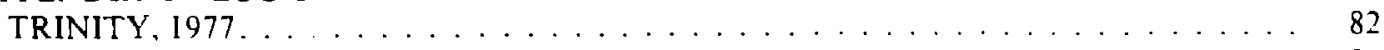

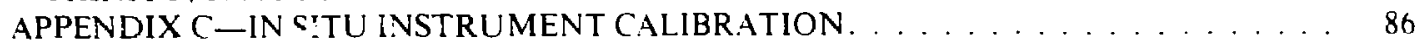

APPENDIX D-INTERPRETATION OF DATA . . . . . . . . . . . . 91

APPENDIX E-SOIIRCES AND EVALUATION OF RADIATION

EXPOSURES.

\section{FIGURES}

1. Central New Mexico. The sitc of the Trinty Test is noted on the left part of the map . . . . . . . . . . . . . . . . . . . . 6

2. Trinity test tower. Oscura Mountains in the background . . . . . . . . . . . . . 7

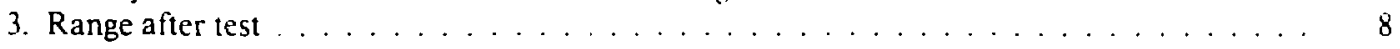

4. Diagram of Trinity $G Z$ fences . . . . . . . . . . . . . . . . . 9

5. The fallout zone from the Trinity test as determined by a 1945 beta-gamma survey. . . . . . . . . . . . . . . . . .

6 Outline map of the contaminated area as determined by 1947 and 1948 survey. A transect was established with numbered laterals . . . . . . . . . . . . . 10

7. General map of the Trinity fallout area and the neasurement locations . . . . . . . . 14

8. Comparison of in sttu and soil sample estimates of total ${ }^{137} \mathrm{Cs}$ inventory . . . . . . . . . 20

9. White Sands Missile Range. Bingham. and Chupadera Mesa sample locations. . . . . . . 25

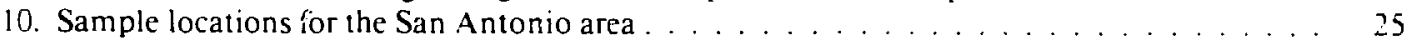

11. External radiation dose rates measured at Trinity Site. June 9. 1983 to June 23.1983 . . . 39

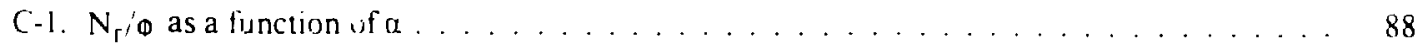

$C-2 . N_{d} / s=N_{f} / \Phi \cdot \Phi / s$ as a function of $\alpha \ldots \ldots \ldots \ldots \ldots$

D-1. Location of June 1983 sampling . . . . . . . . . . . . . . . . . . 93 


\section{TABLES}

1. ESTIMATES OF RISK BASED ON EXPOSURES ATTRIBUTABLE TO RESIDUAL CONT AMINATION IN AREAS OF FALLOUT

FROM THE TRINITY TEST . . . . . . . . . . . . . . . . 3

11. RISK COMPARISON DATA .................... 4

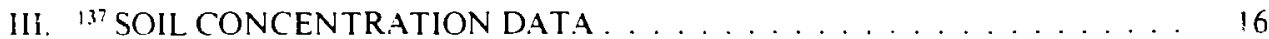

IV. CHUPADERA MESA ${ }^{137}$ Cs PROFILE DATA . . . . . . . . . . . 17

V. GROUND ZERO TO CHUPADERA MESA ${ }^{137} \mathrm{C}$ S PROFILE DATA . . . . . 18

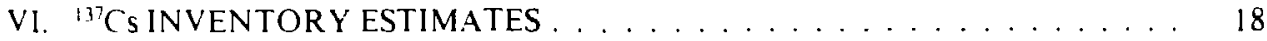

VII. COMPARISON OF IN SITU AND SOIL SAMPLE ESTIMATES OF ${ }^{137} \mathrm{C}$ S TOTAL INVENTORY . . . . . . . . . . . . . . . . 19

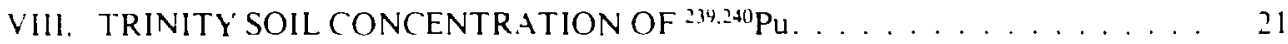

IX. GZENVIRONS AND CHUPADERA MES.A ${ }^{234.241} \mathrm{Pu}$ SOIL CONCENTR.ATION PROFILE ESTIMATES . . . .......... 22

$x$. SURFACE SOIL CONCENTRATION OF ${ }^{238} \mathrm{Pu}$ AND ${ }^{238,2.214} \mathrm{Pu}$ RATIOS . . . . 22

Xi. 1977 ESTIMATES OF I-cm AND TOTAL PLLITONIU M INVENTORI' . . . 23

XII. ACIIVATION AND FISSION PRODUCTS IN BLLK SOIL SAMPLES

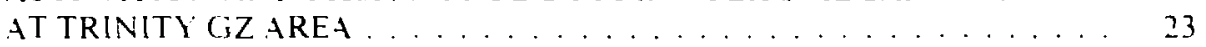

XIII. SOIL CONCENTRATIONS OF NATURALLY OCCURRING

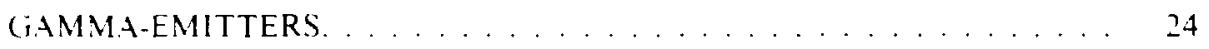

XIV (IROLND ZEROSLRFACE MEASL REMENTS ......... 26

$X V$. WHITE S.ANDS MISSILE R.ANGE FALLOUT ZONE SOIL MEASUREMENTS . . . . . . . . . . . . . . . . . 28

XVI. BINGHAM AREA SOIL MEASLIREMENTS. US HIGHWAY 3?0 CORRIDOR . . . . . . . . . . . . . . . . . . . . 29

XVII. CHUPADERA MESA SURFACE SOIL MEASIJREMENTS . . . . . . . 30

XVIII. FAR FALLOUT ZONE SURFACE SOIL MEASUREMENTS . . . . . . . . . 31

XIX. SAN ANTONIO ARE.A SURFACE SOIL ME.ASUREMENTS . . . . . . . 32

XX. AREAL CONCENTRATIONS OF ${ }^{137} \mathrm{CS} \ldots \ldots \ldots \ldots \ldots \ldots . \ldots \ldots$

XXi. (HUPADERA MIESA IN SITU ${ }^{13}$ CS DATA FOR SOILS BY LAND FORM . . . . . . . . . . . . . . . . . . . 34

XXII. "IISBACKGROLINDINFORMATION .............. 35

XXIII. POTENTIAL CONTRIBUTIONSOF RFSUSPENSION OF $2{ }^{29} \mathrm{Pu}$

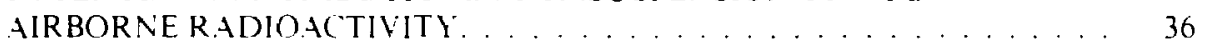

XXIV. EXTERNAL RADIATION EXPOSURE SL;MMARY FOR IN SITU DATA . . . . . . . . . . . . . . . . . . . 37

XXV. EXTERNAL PENETRATING RADIATION MEASUREMENTS AND ESTIMATES OF CONTRIBUITIOR!S FROM TRINITY FALLOUT . . . . . . 38

XXVI. STANDARDS AND GUIDES FOR RADIATION AND R.ADIOACTIVITY ...................... 41

XXVII. INCREMENTAL DOSES. . . . . . . . . . . . . . . . 44

('-I. COUNT R.ATE PER UNIT FLUX AT THE DETECTOR, $N_{\digamma} / \phi$. AS A FUNCTION OF MEASURED $\alpha \ldots \ldots \ldots \ldots \ldots \ldots$

D-1. NORTHERN NEW MEY!' ' BACKGROUND REFERENCE VALUES FOR NATUR.AL OR FALLUUT LEVELS OF RADIOACTIVITY . . . . . . . 92

D-II. 1983 PLUTONIUM DATA FOR SPLIT SPOON CORE SAMPLES FROM GROUND ZERO AREA

D-III. $1983^{19} \mathrm{E}$ U D.ATA FROM SPLIT SPOON CORE SAMPLES IN

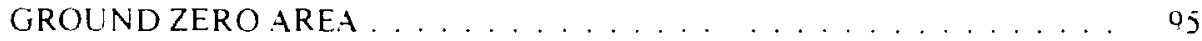

D-IV. JLINE 1983 PLUTONIUM DATA FROM TRINITY GZ AREA . . . . . 96

D-V. PARAMETERS FOR ESTIMATION OF RESUSPENSION OF RADIONUCLIDES USING MASS LOADING 
D-VI. ENRICHMENT FACTORS FOR RESUSPENDABLE PARTICLES . . . . . . 98

D-VII. INHALATION DOSE FACTORS USED . . . . . . . . . . . . . . . . . . . . . . 99

D-VIII. ESTIMATED DOSES FROM INHALATION OF AIRBORNE MATERIALS FROM RESUSPENSION . . . . . . . . . . . . . . . 100

D-IX. INPUT PAP.AMETERS FOR DOSE CALCILATIONS . . . . . . . . . . 101

D-X. INGESTION DOSE FACTORS LISED . . . . . . . . . . . . . . . . . 102

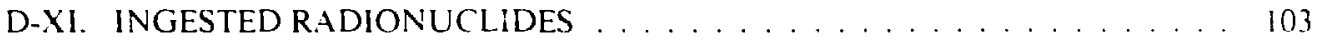

D-XII. ESTIMATED DOSES FROM INGESTION OF FOODS GROWN IN EACH AREA . . . . . . . . . . . . . . . . . . . . . . . . 10.14

D-XIII. ESTIMATED AIR CONCENTRATION FOR SOIL PREPARATION FOR HOME GARDEN . . . . . . . . . . . . . . . . . . . 105

D-XIV. ESTIMATE DOSES FROM SOIL PREPARATION FOR HOME GARDEN . . . . . . . . . . . . . . . . . . 106

E-I. RADIOACTIVE MATERIALSOF PRIMARY INTEREST IN THE RADIOLOGICAL SL'RVEY'

E-II. LINITS OF RADIOACTIV!TY UISED IN THE RADIOLOCICAL SIIRVEY

E-III. STANDARDS AND (ILIDES FOR RADIATION AND RADIOAC'TIVITY' 


\section{Preface}

This series of reports results from a program initiated in 1974 by the Atomic Energy Commission (AEC) for determination of the condition of sites formerly utilized by the Manhattan Engineer District (MED) and the AEC for work involving the handling of radioactive materials. Since the early 1940s, the control of over 100 sites that were no longer required for nuclear programs has been returned to private industry or the public for unrestricted use. A search of MED and AEC records indicated that for some of these sites, documentation was insufficient to determine whether or not the decontamination work done at the time nuclear activities ceased is adequate by current guidelines.

This report contains data and information on the resurvey effort and the effect of residual contamination as a result of nuclear weapons development programs conducted in this area. The report documents the present radiological conditions within the realm of today's sophisticated instrumentation and the impact on any future area developinent.

This report was prepared by the Environmental Surveillance Group (HSE-8), Health, Safety and Environment Division of Los Alamos National Laboratory. This report was compilei and written by Wayne R. Hansen and John C. Rodgers with major contributions from William D. Purtymun, Donald M. Van Etten, John D. Purson and Kenneth H. Rea. Field work in 1977 was directed by Daniel W. Wilson. Field in situ measurements and laboratory sample counting were directed by John Kirby and Douglas Sever of La: rence Livermore National Laboratory. Other Los Alamos personnel involved in measurements were Thomas E. Hakonson, John W. Nyhan, Edward Rahrig, Thomas E. Buhl, and Alan K. Stoker. 


\title{
Fadiological Survey and Evaluation of the Fallout Area from the Trinity Test:
}

\author{
Chupadera Mesa and White Sands Missile Range, New Mexico
}

by

\author{
Wayne R. Hansen and John C. Rodgers
}

\begin{abstract}
Current radiological conditions were evaluated for the site of the first nuclear weapons test, the Trinity test, and the associated faliout zone. The test, located on White Sands Missile Range, was conducted as part of the research with nuclear materials for the World War II Manhattan Engineer District atomic bomb project. Some residual radioactivity attributable to the test was found in the soils of Ground Zero on White Sands Missile Range and the areas that received fallout from the test. The study considered relevant information including historical records, environmental data extending back to the 1940 s, and new data acquired by field sampling and measurements. Potential exposures to radiation were evaluated for current land uses. Maximum estimated doses on Chupadera Mesa and other uncontrolled areas are less than 3\% of the DOE Radiation Protection Standards (RPSs). Radiation exposures during public visits to the U.S. Army-controlled Ground Zero area are less than 1 mrem per annual visit or less than $0.2 \%$ of the RPS for a member of the public. Detailed data and interpretations are provided in appendixes.
\end{abstract}




\section{SUMMARY}

This evaluation of current conditions at the site of the first nuclear weapon test (Trinity) and the associated fallout areas is based on extensive field measurements and sampling followed by interpretation of the resulting data. The study was completed as part of the Formerly Utilized Sir. medial Action Program (FUSRAP) sponsored by the U.S. Departmen: of Energy (DOE).

The Trinity test was part of the research conducted for the World War II Manhattan Engineer District (MED) atomic bomb project. The test was conducted on July 15 . 1945. Measurements of radiation levels at Ground Zero (GZ) and in the fallout zone began the same day. The fallout was blown in a northeast direction over White Sands Missile Range. Chupadera Mesa, and other ranching areas. The land uses in the fallout zone remain the same today. White Sands Missile Range extends north of GZ about $17 \mathrm{~km}$ (10 miles). Privately owned ranch land extends along the path of the fallout zone to the northeast with Chupadera Mesa areas of interest at about $50 \mathrm{~km}$ ( 30 miles) northeast of GZ. Land use on Chupadera Mesa is for cattle grazing. Areas farther out in the iallout area also are used for cattle grazing with small areas of crop production.

This study considered all available relevant information. Records and reports provided the history of the measurements of radidtion and radioa:tivity at GZ and the fallout zone. Environmental measurements and sample results, some extending back to the 1940s, were reviewed for information on trends and patterns. Data from these and special radioecology research studies were compiled to provide a basis for planning the acquisition of new data. Most of the new data consist of sevcral hundred field measurements and samples of soil and vegetation.

The findings, based en interpretation of the: data, are expressed in this summary as maximum increments of risk to hypothetical individuals exposed to the existing conditions. Individual risks of cancer from exposure to radiation were calculated from factors derived from the National Academy of Sciences 1980 study. Potential exposures to radiation for various possible mechanisms were generally calculated as 50-year committed dosc equivalents resulting from 1 -year exposures to account for cumilative doses from those radioactive materials retained in the body for varying periods after initial exposure. Exposure to natural background results in exactly the same kind of risks. The risk-estimating factors were applied to natural background radiation as measured in north central New Mexico to provide one context for judging the significance of other risks. People living in northern New Mexico incur an estimated incremental risk of cancer mortality of 8 chances in 10000 . or a probability of $8 \times 10^{-4}$. from a 50 -year exposure to the natural radiation background. The natu ral radiation background dose, about 150 mrem each year. includes contributions from cosmic radiation. natural terrestrial radioactivity, and natural radioactivity incorporated in the body. A larger perspective is that the overall U.S. population lifetime risk of mortality from cancers induced by all causes is currently about 2 chances in 10 . or a probability of 0.2 .

The maximum likely incremental risks from all mechanisms of potential exposure in the areas having residual radioactivity attributable to the residual radioactivity range from about 2 chances in $10000\left(2 \times 10^{-4}\right)$ in the restricted use area to a minimum of 6 chances in $10000000000\left(6 \times 10^{-10}\right)$ under current conditions of land use as suinmarized in Table I. The merhanisms include direct exposure to penetrating radiation and inhalation of resuspended dust.

Table I gives the incremental risks of cancer mortality, bone cancer. and lung cancer, along with the 50-year dose commitments from which they were calculated. All of the dose commitment values are considered overstated to some degree because assumptions used in their derivation were inade to maximize estimates of potential effects. All of the dose commitments are small fractions of those permitted above natural background and medical exposure by the DOE Radiation Protection Standards (RPSs). Maximum estimated doses on Chupadera Mesa and other uncontrolled areas are less than $3 \%$ of the RPSs.

Another context for judging the significance of these risks associated with exposure to radiation, whether from 
natural background or other sources, is a comparison with risks from other activities or hazards encountered in routine experience. Table II presents a sampling of risks for activities that may result in early mortality and annual risks of death from accidents or natural phenomena. Because not all of the risks are directly comparable, the values for mortality risks shown in Table I overlap the range of values for risks shown in Table II. The largest incremental risks from the exposure to the residual contamination are about the same size as the incremental risk of a 1000-mile automobile trip; most are sma!ler than the annual risk of death fro:n lightning.

Some differences in future conditions will result from radioactive decay processes. While the total doses from transuranium elements will noi change appreciably, the doses fron ${ }^{90} \mathrm{Sr}$ and ${ }^{137} \mathrm{C} 5$ will decrease $50 \%$ in about 30 years. At the GZ area the external radiation doses wil! decrease about $90 \%$ in the same 30 year period.

TAHLE I

YSIIMAILS OF KISK BASIDD ON IXXOSURES ATTRIBLIABLE TO RISIDUAL CUNTAMINATION IN AREAS OF FALLOUT FROM THF TRINITY TESI"

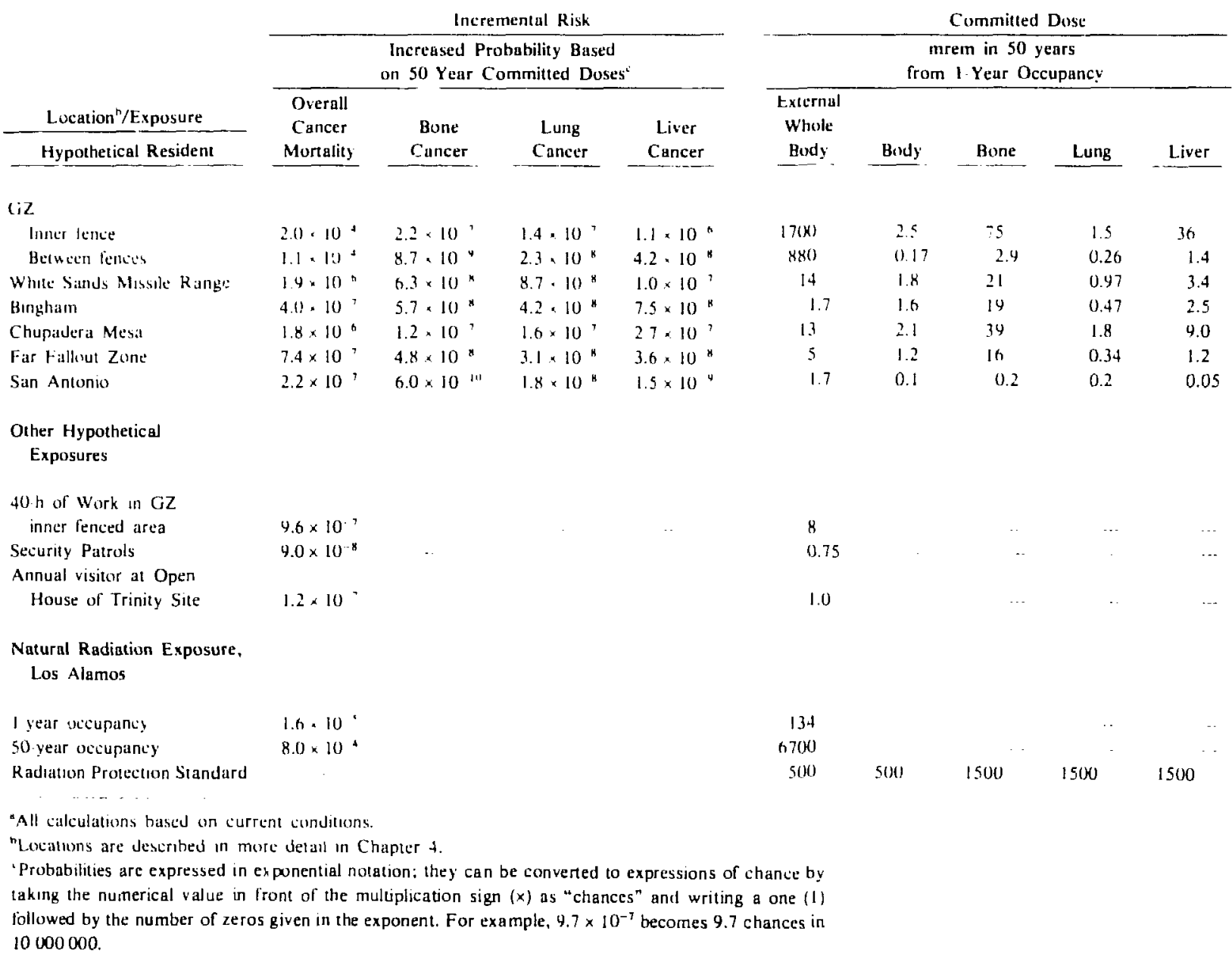


TABLE II

\section{RISK COMPAKISON DATA}

Individual Increased Chance of Death Caused by Selected Activities

Activity

Smoking I pack of cigarettes (cancer, heart disease)

Drinking $1 / 2$ liter of wine (cirrhosis of the liver)

Chest $\mathrm{x}$-ray in good hospital (cancer)

Travelling 10 iniles by bicycle (accident)

Travelling 1000 miles by car (accident)

Travelling 3000 miles by jet (accident, cancer)

Eating 10 tablespoons of peanut butter (liver cancer)

Eating 10 charcoal broiled steaks (cancer)
Increase in Chance of Death
$1.5 \times 10^{-3}$
$1 \times 10^{-6}$
$1 \times 10^{-6}$
$1 \times 10^{-6}$
$3 \times 10^{-6}$
$3.5 \times 10^{-6}$
$2 \times 10^{-7}$
$1 \times 10^{-7}$

U.S. Average Indiviuual Risk of Death in One Year Due to Selected Causes

Cause $\quad$ Annual Risk of Death

Notor Vehicle Accident

Accidental Fall

F:-es

Drowning

Air Travel

Electrocution

Lightning

Tornadoes
$2.5 \times 10^{-4}$

$1 \times 10^{-4}$

$4 \times 10^{-5}$

$3 \times 10^{-5}$

$1 \times 10^{-5}$

$6 \times 10^{-6}$

$5 \times 10^{-7}$

$4 \times 10^{-7}$

\section{U.S. Population Lifetime Cancer Risk}

Contracting Cancer from All Causes 


\section{INTRODUCTION AND BACKGROUND}

\section{THE DOE RESURVEY PROGRAM}

The 1977 and 1983 survey of the Trinity Site was carried out as part of the DOE program aimed at formulation of any remedial actions for Manhattan Engineer District (MED) or Atomic Energy Commission (AEC) sites. In the DOE program, files were reviewed to determine if residual radioactive contamination might exist at the sites. If the radiological conditions were uncertain, a survey of the area influenced by the site was performed. The files and special studies in existence for the Trinity Site indicated a survey would be necessary to quantify the radiological condition of the 32-year-old fallout area from the first nuclear explosion at White Sands Missile Range in New Mexico, July 16, 1945.

Several studies of the fallout zone had been carried out before the resurvey. These included surveys immediately after the test in 1945, studies by University of California, Los Angeles (UCLA) in 1948, 1950, and 1951. In 1973 and 1974, the U.S. Environmental Protection Agency (EPA) carried out an extensive soil sampling program for plutonium in the area. The study included air samplers located on Chupadera Mesa and in Socorro, New Mexico. Starting in 1972 and continuing until 1979, Los Alamos Scientific Laboratory, conducted special ecological studies of the movement of ${ }^{137} \mathrm{Cs}$ and plutonium isotopes on study plots on Chupadera Mesa and near Ground Zero (GZ) located on White Sands Missile Range. Factors influencing the survey were the history of the Trinity test, previous studies of the fallout zone, and the stated objectives of the Formerly Utilized Sites Remedial Action Program. Each of these factors is discussed in more detail in following paragraphs. Separate chapiers are devoted to the resurvey plan, the results, and interpretation of the data. Appendixes are included that contain the historic data base, the raw data from this study, a log containing locations of sample locations, calibration methods for the in situ detector system used, and calculational methods used for estimations of radiation dose equivalents from any residual fallout radionuclides.

\section{TYE TRINITY TEST}

The Trinity test of the first atomic bomb took place on July 16, 1945, on White Sands Missile Range in Central New Mexico. The test resulted in deposition and dispersal of radioactive fallout over a portion of central and northeastern New Mexico. Figure 1 is a map of the gineral area with Trinity Site marked on the lower lefthand corner of the map. The device was mounted on a 100 -foot tower with cables for instruments and timing strung to shelters $9144 \mathrm{~m} \mathrm{(10000} \mathrm{yds)} \mathrm{away.} \mathrm{Figure} 2$ is a photograph of the tower-mounted device before the test. The Oscura Mountains are in the background of the photograph about 5 miles east of the test area.

Weather on the day of the test started out being cloudy and windy with scattered showers. At 2:00 a.m., the test was rescheduled from 4:00 a.m. to 5:30 a.m. At 4:00 a.m., the rain stopped and at 4:45 a.m., a favorable weather forecast indicated the 5:30 a.m. time was acceptable. Weather remained cloudy after the test, as observed by planes sent to drop sensors during and after the test. ${ }^{1}$ After the test, a crater and zone of melted sand were created (Fig. 3). The green fused sand is referred to as Trinitite in many reports. The GZ area has been designated a National Monument. As noted earlicr, GZ is located on White Sands Missile Range, and access is controlled throughout the year. Once annually, the public is invited for a controlled visit to the site, usually in the month of October. Figure 4 is a diagram of the GZ fenced area included in the public visits.

\section{THE TRINITY FALLOUT ZONE}

Following the test, measurements were made to establish the trajectory of the fallout cloud and the deposition pattern over Chupadera Mesa and areas northeast of GZ. Measurements during 1945 were made across the fallout pattern to outermost edges of the fallout zone.

Figure 5 is a depiction of the fallout zone based on beta-gamma surveys of the soil surface following the test. The fallout followed a northeasterly direction paralleling 


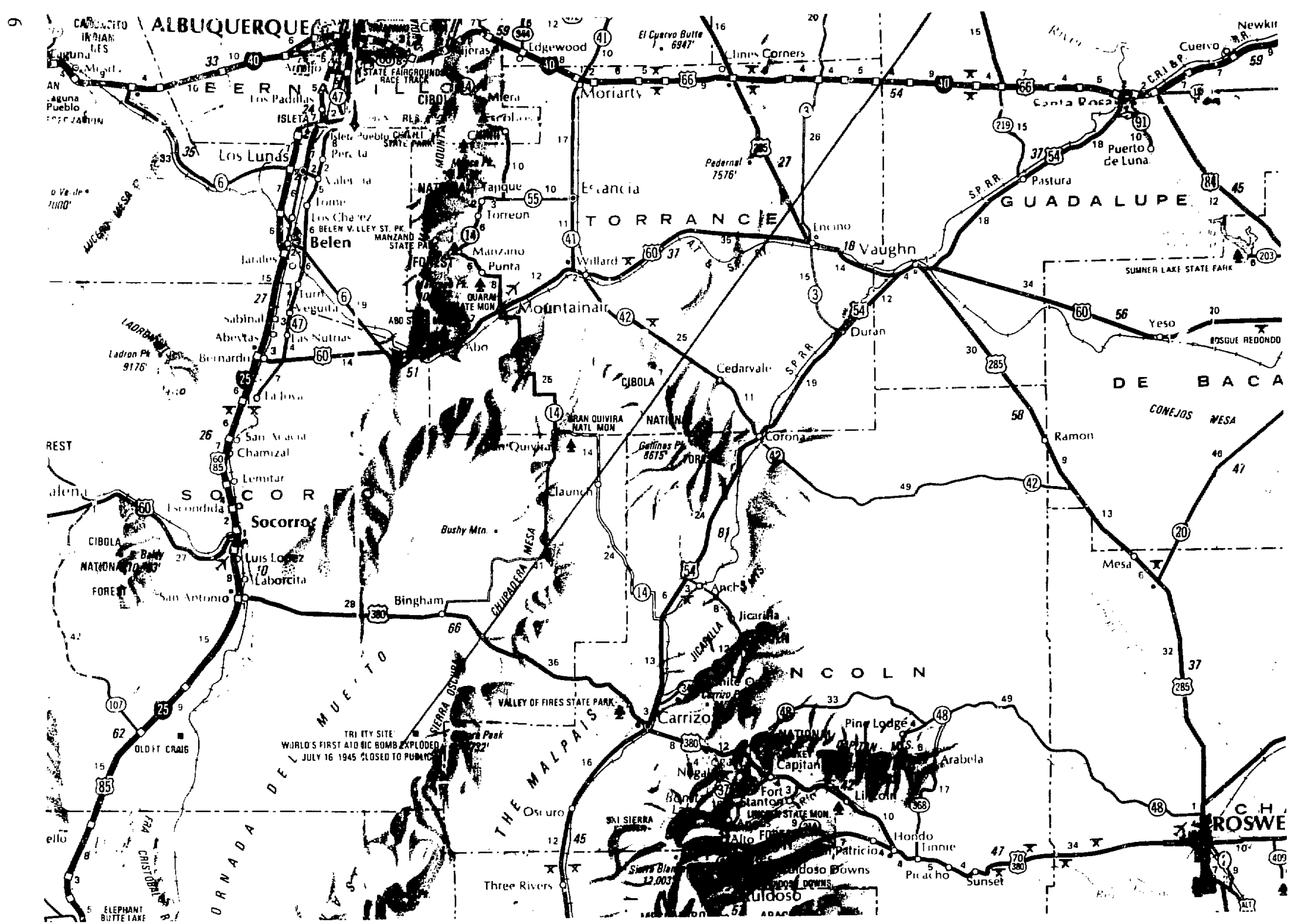

Fig. 1. Central New Mexico. The site of thr Trinity Test is noted on the lower left part $c_{\lrcorner}^{\prime}$ the map. 


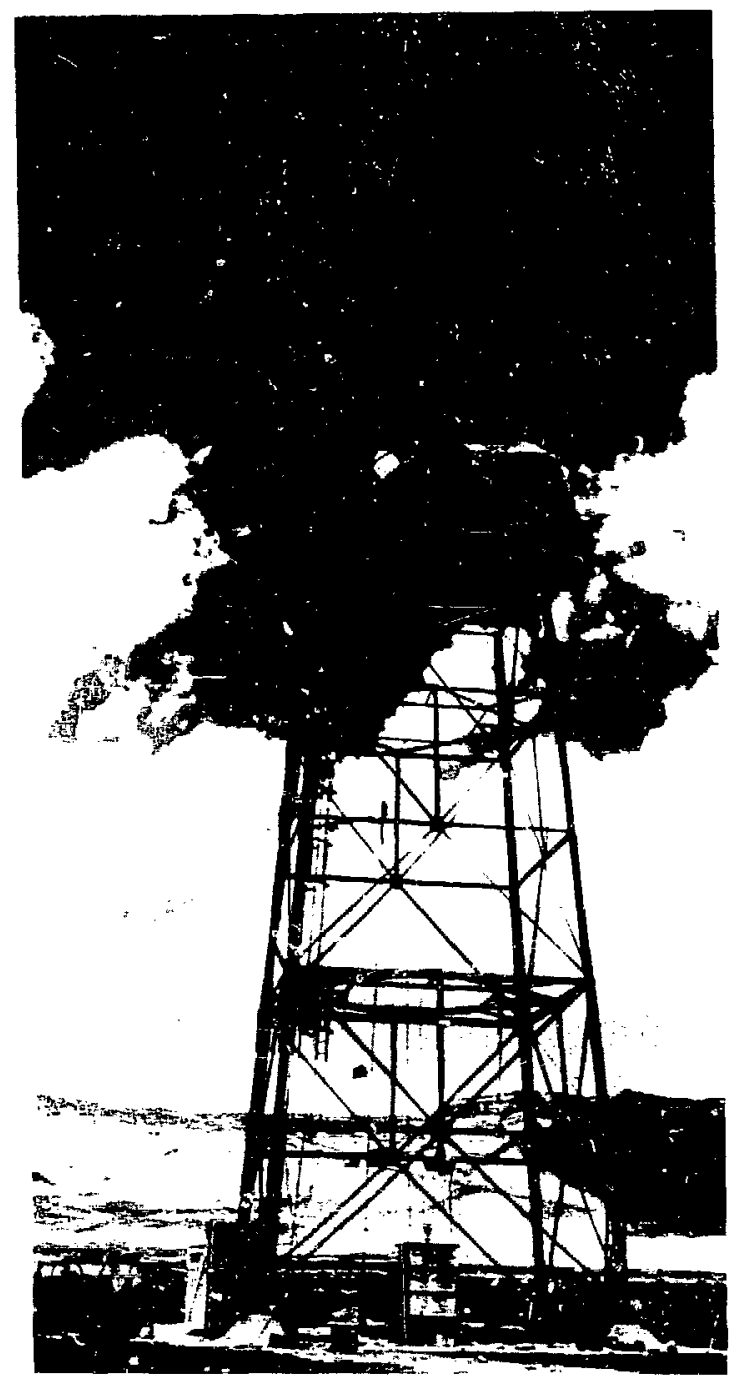

Fig. 2. Trinity test tower. Oscura Mountains in the background.

the west of U.S. Highway 54 (Fig. 1). The cloud passed over Chupadera Mesa, where localized areas of higher levels were ohserved.

Another beta-gamma survey carried out in 1947 and 1948 confirmed the earlier observations and added detail to the mapping of the area. ${ }^{2}$ Figure 6 is an outline map of the contaminated area taken from the 1947 and 1948 studies. $^{2}$ A primary transect reference line was established in the 1947 study. The transect of $34^{\circ} 56^{\circ}$ started at the Section Marker at GZ At every 4930 feet, reference points were marked for the first 11 points. At point 12 , the reference points were marked every 9000 feet. Fron this primary transect, reference line laterals were extended $90^{\circ}$ right and left. Sampling and study areas were established arcording to the lateral numbers. For example, an area of special stuay on Chupadera Mesa at lateral 21 (about 28 miles from GZ) is referred to as area 21 . This type of designation is referred to in reports of several studies of the Trinity fallout zone.

Since 1945, radioactive decay has resulted in substantial reductions of the fallout levels so that only the longlived radionuclides ${ }^{90} \mathrm{Sr},{ }^{137} \mathrm{Cs}$, and ${ }^{239} \mathrm{Pu}$ with traces of europium. remain. In the intervening years, environmental and biological transport processes such as erosion, sedimentation, and biotic uptake have acted on the initial surface deposition to redistribute these long-lived radionuclides. A number of studies were carried out to characterize the radionuclide distribution and redistribution in the years following the test.

The first major studies were carried out between 1947 and 1950. These studies emphasized radionuclide concentrations including plutonium for soils and plants, particularly on Chupadera Mesa, the crater region, and the region no:th of the crater, but still on White Sands Missile Range, ${ }^{3,4}$ The studies included characterization in the soils and plants of the area.

Plant studies included a study of the revegetation of GZ. Studies were also carried out that involved descriptions of the movement of small mammals, reptiles, and birds in the area surrounding GZ. ${ }^{5}$ The results of these studies have been included in considerations of the design of this study.

In summary, elevated levels of plutonium and fission products were measured in the fallout pattern. The maximum concentrations in soil outside the fenced area of GZ were detected on Chupadera Mesa about 28 miles from $\mathrm{GZ}$. The authors suggest a localized rain shower may have scrubbed a portion of the fallout cloud. ${ }^{4}$ During the study period of 1947101950 , there also was observed some downward migration of fission products in the soil. However, wind erosion in the crater area of GZ was relatively more important than water in spreading the contamination. ${ }^{6}$ Plutonium was found in amounts up to $19 \mathrm{pCi}$ per square foot at area 21 . No plutonium was found in samples collected 3 miles south of GZ. ${ }^{7}$ Studies of plant invarivin of the crater area through 1964 con$c_{1}$ ded that, while the area had not returned tc climax vegetation, w.stributional patterns were controlled by water availability, soil conditions, and timing of climatic variants rather than radiation. ${ }^{8}$ 


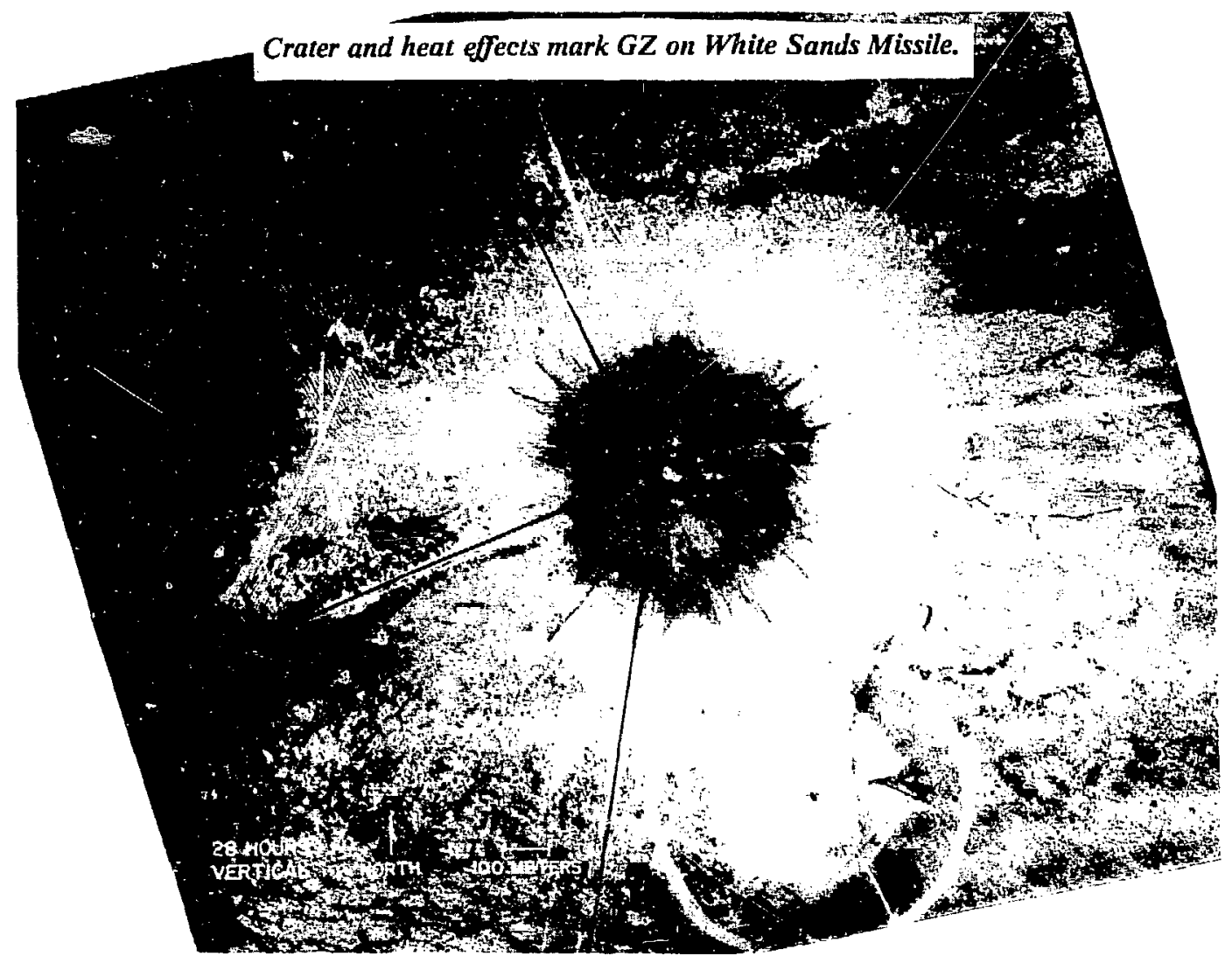

Fig. 3. Range after test.

In 1972. a series of special studies of the plutonium distribution were started by Los Alamos Scientific Laboratory. Soil. vegetation, and rodent samples along the fallout transect were obtained at GZ and out to $56.4 \mathrm{~km}$ ( 35 miles). ${ }^{9}$ Soil samples from $\mathrm{GZ}$ indicated a relatively uniform vertical distribution of plutonium in the $30-\mathrm{cm}$ deep soil samples. Increased migration of plutonium into the soil was observed. Concentrations of plutonium in vegetation and rodents were too low to make valid comparisons. From the data taken, four intensive study areas were established at $1.6 \mathrm{~km}, 16 \mathrm{krn}$, and $44 \mathrm{~km}$. in addition to a control site south of GZ. ${ }^{10}$ About half of the ${ }^{239,240} \mathrm{Pu}$ in the Trinity fallout zone soils was found at the 5- to 20-cm depth in 1973 compared with total plutonium inventories being detected only in the upper $5 \mathrm{~cm}$ of soil in previous studies ( 21 to 25 years). Penetration depths of ${ }^{239.240} \mathrm{Pu}$ into the fallout zone soils were related to the presence of subsoil horizons containing carbonate accumulations and to the extent of rainwater penetration into the soil profiles. ${ }^{10.11}$ Studies of plutonitim as related to concentrations on vegetation indicate concentration ratios as high as 1.0 for dry weights. ${ }^{12} \mathrm{~T}$ ree range for forbs was 0.04 to 1.1 and grasses 0.05 to 1.2. Contamination of plant surfaces with soil particles is considered the cause of plant-soil ratios higher than observed in greenhouse studies.

In 1973 and 1974, the EPA sampled and analyzed soils from across the region of the Trinity fallout field for ${ }^{239} \mathrm{P}_{4}$ and ${ }^{240} \mathrm{Pu}$ in the top $5 \mathrm{~cm}$ of the surface soil. ${ }^{13}$ Before publication, the results of the survey and the field notes from the sampling were forwarded to Los Alamos by the EPA. The highest surface plutonium level was observed on the White Sands Missile Range. The GZ sample contained $1100 \mathrm{nC}$ : of ${ }^{239,241} \mathrm{Pu}$ per square meter of soil surface. A soil sample taken approximately $3.2 \mathrm{~km}$ ( 2 miles) north of $\mathrm{GZ}$ contained $100 \mathrm{nCi}$ per square meter, but neigiboring sample locations gave plutonium value factors of 4 to 10 times lower. 


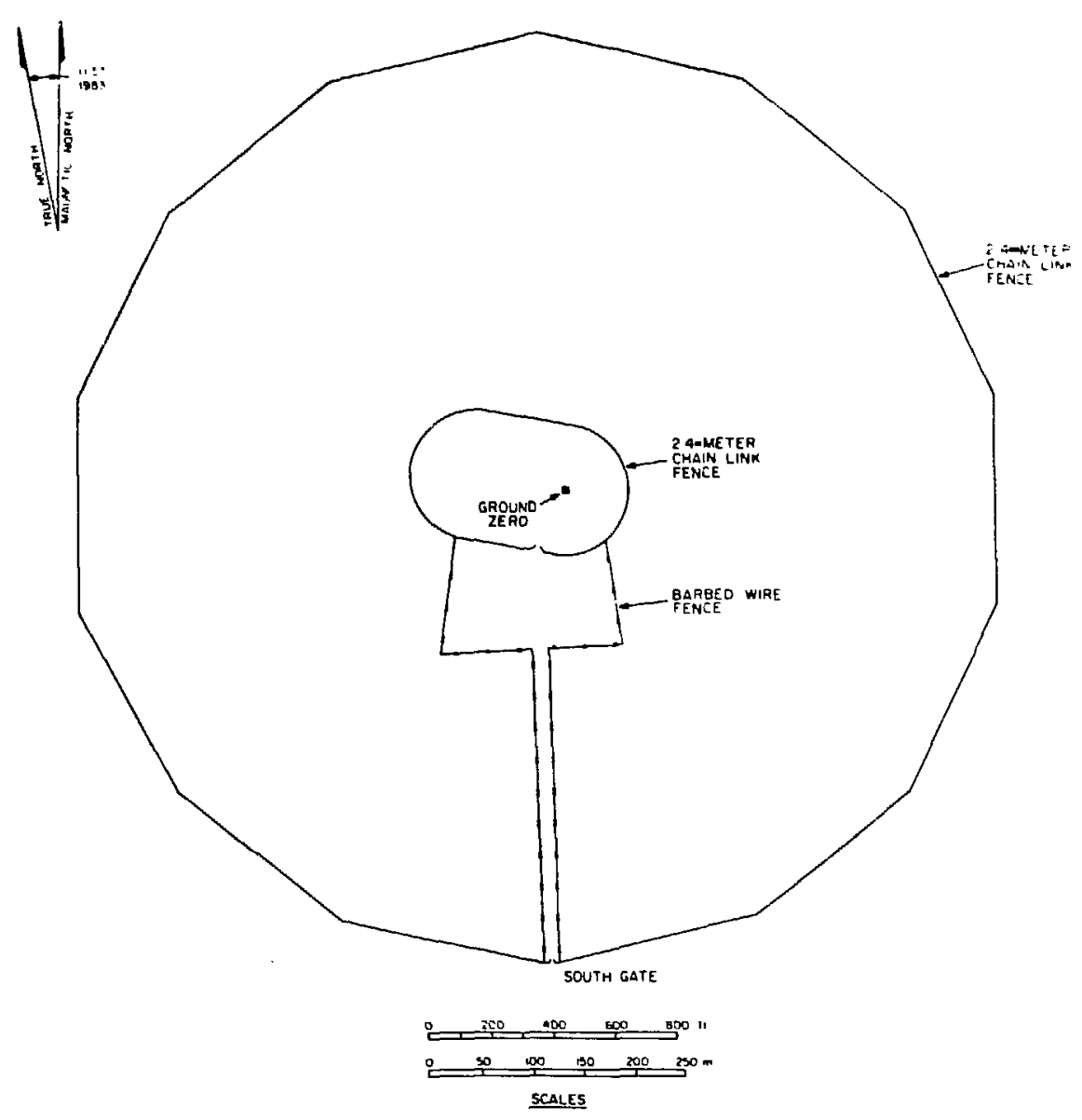

Fig. 4. Diagram of Trinity GZ fences.

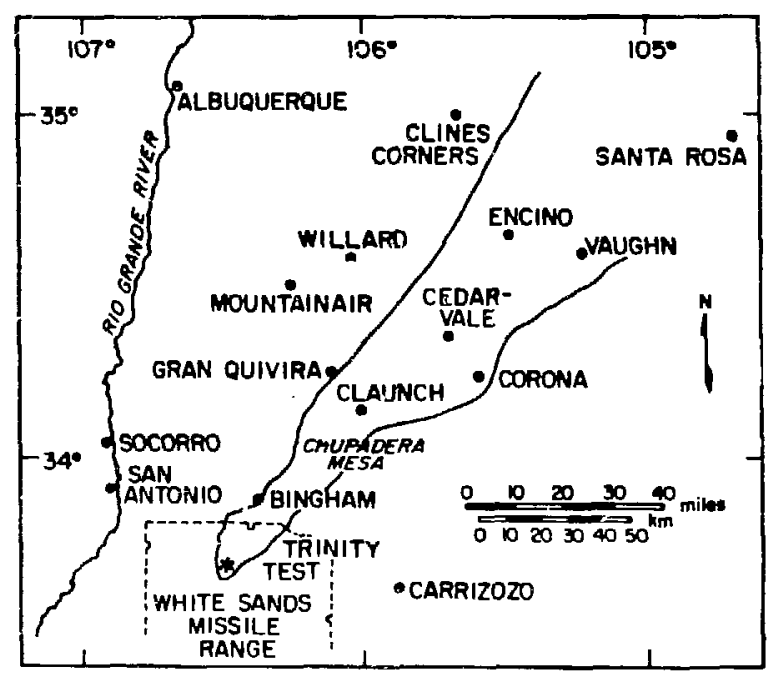

Fig. S. The fallout zone from the Trinity test as dctermined by a 1945 beta-gamma survey.
Consistent with earlier findings of the initial fallout distribution, plutonium levels generally decrease with distance from $\mathrm{GZ}$ and with lateral distance from the centerline. The increase or. Chupadera Mesa, some 20 to 30 miles from $G Z$, is also observed in the data. The highest level reported by EPA on the mesa at a single location was $86 \mathrm{nCi}$ per square meter. Background values, that is, the minimum values, were reported at less than $1 \mathrm{nCi}$ per square meter.

The EPA study also included carrying out air sampling for airborne plutonium. An air-sampling station was established at Socoris, New Mexico, and another airsampling station was established at Monte Puerto Ranch on Chupadera Mesa. Air samples were collected over a 10-month period. The samples were analyzed for ${ }^{239,240,238} \mathrm{Pu}$. The Socorro station asted as a control area because it was located out of the fallout zone. The ${ }^{238} \mathrm{Pu}$ results from both locations were below the detection level 


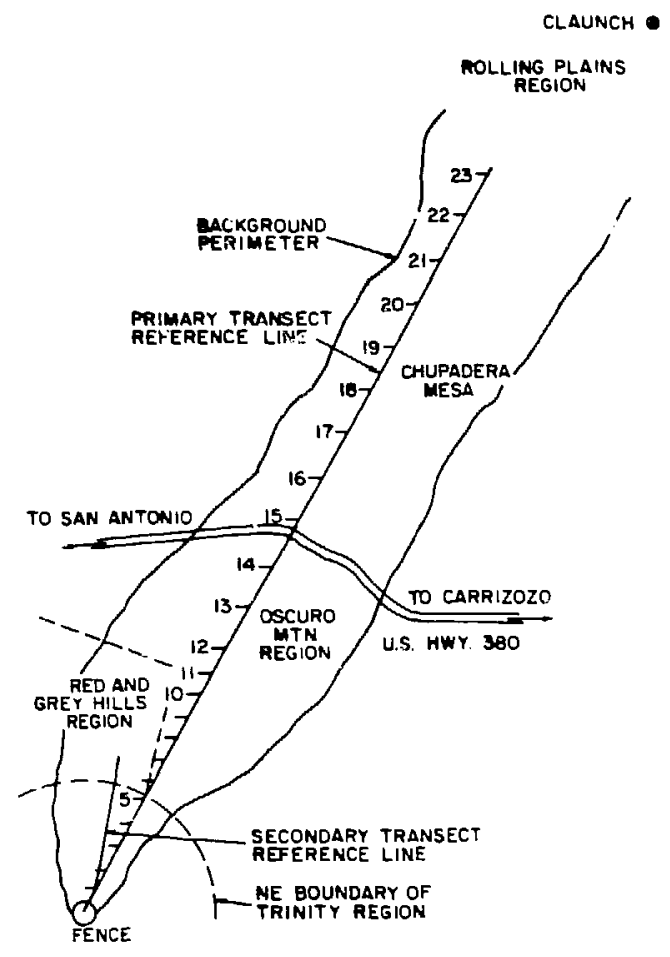

Fig. 6. Outline map of the contaminated area as determined by 1947 and 1948 survey. A transect was established with numbered laterals.

on many of the samples. Often, the results for ${ }^{239,240} \mathrm{Pu}$ also were below detection limits, and only the data pertaining to the detected plutonium were reported. The primary reslits of the air sampling indicated that the air concentrations were well below the proposed EPA limit for transuranics deposited on soils. The conclusion of the study indicated that, while higher plutonium levels could be found at very localized individual sites, the sampling density used in the study on Chupadera Mesa makes it unlikely that grossly higher levels are present in the area exceeding the EPA proposed guidance.

Because the EPA study limited itself to plutonium, it was decided that the 1977 resurvey of the fallout zone would include fission product and activation product measurements in addition to confirmatory plutonium measurements. Data for the resurvey concentrated in areas in the far fallout zone (the area north of White Sands Missile Range, and in particular, Chupadera Mesa) because, at the time, it was felt this was the most important area.

\section{THE RESURVEY OBJECTIVES}

As previously mentioned, a number of studies have taken special views of either the early distribution of fission products, or later, the distribution of plutonium. The special Los Alamos ecology studies concentrated on intensive studies of four relatively small areas, 1 hectare in size. The EPA study concentrated on the characteriza . tion of plutonium mainly in the Chupadera Mesa area. These data are included in the data base of this study (Appendix A). The objective of this study, however, was twofold. The first objective, that of the resurvey program, was to design a sampling program that would allow the estimation of radiological dose to people living in the area for current land uses. These land uses are for grazing cattle and small home gardens. It is anticipated that GZ and the White Sands Missile Range will remain in control of the U.S. Army. Second, bec ause a data base existed for a number of years and it is known from the earlier studies that wind and water played a major role in redistribution of the fallout material, it was decided that the study would also make special measurements to investigate redistribution of the materials from the actions of wind and rain. Because high-resolution germanium lithiumdrifted $[\mathrm{Ge}(\mathrm{Li})]$ gamma detectors now exist, and are usable under field situations, it was decided to use the Lawrence Livermore Laboratory mobile radiation detection system. Use of the germanium detector with a pulse height analyzer in a mobile unit enabled the measurement of the distribution of fissiun prcducts in soil in a rapid manner.

Redistribution of the surface-deposited fission prod ucts and plutonium was an important consideration of the studies carried out during the UCLA series in 1947 to 1951. A strong redistribution of surface soil by both wind and rain was observed. Flash floods do occur in the area and tend to move soils and sediments in runoff channels in large quantities. Points of deposition for these sediments that are moved by heavy water events are usually low points that are often dug out to collect the water for livestock watering. Therefore, the study included a number of measurements where the ${ }^{137} \mathrm{Cs}$ content was measured both upslope and at the final deposition point for redistribution of the fission products and probably of plutonium also.

To evaluate the significance of the residual contamination at the GZ location, a series of core samples was taken in 1983. 


\title{
3. METHODS AND APPROACH
}

\begin{abstract}
This study was designed to supplement existing data on the distribution of fallout from the Trinity Test tu allow estimation of potential radiation doses based on land use. The sampling program took advantage of previous studies of the fallout area, as well as special studies of small areas of the fallout zone.
\end{abstract}

\section{APPROACH}

Previous surveys had determined the extent of the fallout area and general concentrations of surface deposition of fallout. Later studies by Los Alamos National Laboratory concentrated on the mechanisms for redistribution of the fallout in several intensive study areas. ${ }^{14}$ In the case of the U.S. Environmental Protection Agency studies, the principal investigator provided field notes so sample locations could be relocated for further sampling.

The sampling programs were carried out during two time periods. In 1977 the far fallout zone. Chupadera Mesa, and areas around GZ on White Sands Missile Range were sampled. Because time and resources were limited, maximum use of previous survey resuits guided the plan for characterization of the residual fallout radionuclides. Also, the loan of a van with instrumentation and personnel from Lawrence Livermore National Laboratory allowed use of real-time data for decisions about measurement locations in the field. In 1983 a set of measurements and samples was taken at GZ. Analysis of the 1977 survey data had indicated more detailed information on the depth distribution of radionuclides at $\mathrm{GZ}$ would be necessary for engineering studies of the area. In both surveys, in situ measurements with a germanium lithium-activated $[\mathrm{Ge}(\mathrm{Li})]$ high-resolution gamma-ray spectrometer and special sampling methods were used to obtain information on the concentrations and location of radionuclides.

\section{METHODS}

\section{A. In Situ Measurement}

In planning the Trinity survey effort, it was determined that the utilization of in situ $\mathrm{Ge}(\mathrm{Li})$ spectrometry would provide a nurnber of advantages over sole reliance on traditional soil-sampling techniques for obtaining an inventory of radionuclides in the soils of a very large Trinity fallout field. The following considerations were taken into account.

(a) The relatively short counting time required to obtain a satisfactory gamma spectrum for a sample (30 min compared with 1000-2000 $\mathrm{min}$ in the laboratory for a 100 -g soil sample) allows a potentially larger number of sample locations to be Examined. Alternatively, it allows the reallocation of laboratory $\mathrm{Ge}(\mathrm{Li})$ analysis time to the necessary soil profise concentration determinations in support of the in situ measurements.

(b) Local inhomogeneities in soil radionuclide concentration (both in depth and in small regions) are automatically averaged because the detector is responding to photons from a very large quantity of soil (several metric tons compared with a few hundred grams in a laboratory system).

(c) Combining the inherently high resolution of a $\mathrm{Ge}(\mathrm{Li})$ spectrometer system with a motile detector and support system permits immediate feedback in the field of both radioisotope identity and relative activity (cpm), which allows on-site decisions to be made concerning what additional or different measurements might be needed and where.

The methodology and instrumentation for and feasibility of utilizing in situ $\mathrm{Ge}(\mathrm{Li})$ spectroscopy for identifying and quantifying radionuclides distributed in soil have been investigated and successfully demonstrated at several laboratories over the past several years. ${ }^{19-19}$ For the Trinity resurvey, equipment and techniques developed by the Lawrence Livermore National Laboratory (LLNL) were utilized through a cooperative arrangemeni. An overview of the system and its calibration are found in published reports. ${ }^{17}$ 
The response of a closed-end, cylindrical $\mathrm{Ge}(\mathrm{Li}) \mathrm{de}-$ tector, placed at a fixed height ( 1 meter) above the soil, is an energy-dependent function of the angular response of the detector and the flux of unscattered photons incident on the detector per unit of soil radioactivity. Normaily, calibration of this response involves laboratory measurements and calculational procedures independent of the geometries of the distributed sources to be evaluated. Radionuclides that have been redistributed through the vertical soil profile from an initial surface deposition (for example, fallout) are usually assumed to be exponentially distributed in this calibration calculation. As a srosscheck of the laboratory calibration and the suitability of the exponential distribution assumption, an empirical calibraion factor for ${ }^{137} \mathrm{Cs}$ was derived as well.

Although detector response to a source does depend on such variables as the mass attenuation coefficients and densities of soil and air under field conditions, the crucial variable is the specification of the reiaxation depth of the activity raing measured (that is, the inverse of t: $\mathrm{r}^{2}$ power of the exponential distribution function). Under cercain circumstances this parameter can be readily and reliably estimated, as in the case of fresh fallout of short-lived radionuclides ( ${ }^{7} \mathrm{Be}$, for instance) or the case of naturally occurring radionuclides such as uranium, which tend to be uniformly distributed in soil. But the case of aged, long-lived fallout radionuclides deposited over as large and varied terrain as is found in the Trinity fallout field presents a more difficult condition to interpret. Concentration profiles for ${ }^{137} \mathrm{Cs}$ were determined at reasonably representative locations throughout the field by the technique of soil sampling and laboratory $\mathrm{Ge}(\mathrm{Li})$ analysis. As might be expected, these distributions reflect in a complex way the effects of the wide differences in rainfall input. soil properties and depth, and vegetation type and density, which occur over the range of low-elevation, dry desert terrain, through the grass and piñon-juniper habitat of the mesas, to the conifer forests of the mountain slopes. Representative values were selected and assigned by judgment to each sample location. An effort to develop a linear box model of redistribution of ${ }^{137} \mathrm{Cs}$ following deposition was made, but the many uncertainties in estimating the relevant parameters in the model led to results judged to be of no more value than making assignments on the basis of proximity to measured profiles, similarity of soil type, vagetation, elevation, and so forth.

\section{B. Sampling and Analysis}

Sampling of soils, sediments, and vegetation accompanied most in situ measurements throughout the survey area. Of particular importance were soil profile samples taken at the location of the in situ measurement. These soil profile samples were used to develop a correction factor for calibration of the $\mathrm{Ge}(\mathrm{Li})$ detector system to account for the depth distribution of gamma-ray enitting radıonuclides.

The methods used for obtaining samples and subsequent analysis considered the sensitivity of the systems used and the survey design. At locations with changing topographical features, additional soil samples were taken to study plutonium and strontium distribution. These isotopes are not present in sufficient quantity for detection by the in situ measurement system used.

Soil samples were obtained lising a $12.8-\mathrm{cm}-(5-\mathrm{in} .-)$ diameter ring that was pushed or pounded $5 \mathrm{~cm}(2 \mathrm{in}$.) into the soil. Soil was removed from around the ring by use of a shovel and hand trowel. An aluminum sheet was pusined under the ring and both soil and ring were lifted out. The soil was collected in plastic bags labeled with the location identification and an indication of the depth and soil horizon sampled. The procedure was repeated for each soil profile sample, taking care to avoid cross contamination. At each in situ measurement location, three 5-cm-deep soil profiles or a total of $15-\mathrm{cm}-(6-\mathrm{in} .-)$ deep samples were obtained. At selecteo locations, profile depths to $40 \mathrm{~cm}$ (16 in.) were sampled.

Vegetation samples were collected using grass shears to cut the grass or weeds within 1 to $5 \mathrm{~cm}$ of the soil surface. For trees, new growth and the last ycir"s growth were collected. Samples were placed in plastic bags with notation of the plant species and the identification number for that location. Notes were made on the vegetative cover, measured slope, and soil characteristics. Topographic features of the surrounding area also were noted. Additional vegetation samples were collected for later verification of species types.

Soil and vegetation samples were transported daily to laboratories at New Mexico Institute of Mining and Technology in Socorro, New Mexico. Samples were placed in drying racks of window screen on wood frames in an unused greenhouse. After initial air drying, heat lamps were used to dry the samples to constant weight. Constant weight was attained in I hour under the heat 
lamps. A drying time of 2 hours for both soils and plants was used as routine practice. After they were dried, soil and plant samples were pulverized using Waring Blendors. Vegetation samples were packed into cans by overfilling above the top of the container. A manual can se 'er compressed the sample while the lid was fastened to the can. About $80 \mathrm{~g}$ of dried vegetation was sealed in the san for later counting on a laboratory $\mathrm{Ge}(\mathrm{Li})$ detector system. At the same time, $10.05 \mathrm{~g}$ of sample was weighed into a plastic sample bottle and labeled for transport to Los Alamos National Laboratory, where radiochemical analyses were conducted. Soil samples were homogenized and about $360 \mathrm{~g}$ filled the cans. Samples of $10.05 \mathrm{~g}$ of each soil or sediment sample were placed in small plastic bottles and labeled for transport to Los Alamos National Laboratory radiochemical laboratories.

Because the soils were anticipated to contain greater quantities of radionuclides than vegetation, a separate laboratory was used for soil handling. Samples from the GZ area were handled with special precautions because of higher radionuclide contents. Special laboratory cleaning before and after handling these segregated samples minimized cross-contamination potential.

Vegetation and soil samples were counted on a $\mathrm{Ge}(\mathrm{Li})$ system at New Mexico Institute of Mining and Technology as an initial screening method for radionuclide identification. Final analysis of the samples for gammaemitting radionuclidıs was conducted by LLNL with calibrated laboratory $\mathrm{Ge}(\mathrm{Li})$ systems and data reduction accomplished using computer codes. ${ }^{20}$

Vegetation and soil samples sent to the Los Alamos environmental surveillarce radiochemistry laboratories were analyzed for ${ }^{238} \mathrm{Pu},{ }^{239,240} \mathrm{Pu}$, and ${ }^{90} \mathrm{Sr}^{21}$ Plutonium analyses used standard digestion, anion exchange, plating, and alpha spectroscopy methods. Stron'ium-90 anal$y$ ses utilized standard ${ }^{90} \mathrm{Y}$ ingrowth methods. 


\section{RESULTS}

\section{TOTAL AREA}

For an overview of the amount of radioactive fallout from the Trinity Tesh, the data have been reviewed for overall measurement of ${ }^{137} \mathrm{Cs},{ }^{239,240} \mathrm{Pu}$, and other radionuclides. Figure 7 is a general map of the Trinity fallout area. Data points are designated as small squares. The solid lines divide the data base inic areas of generai interest for assessment of thit re-dionuclides on more areaspecific bases. The data base was divided into areas designated: Trinity GZ, San Antonio, White Sands Missile Range, Bingham, Chupadera Mesa, and Far Fallout Zone. Section II of the Results presents the mean data by area. Appendix A lists the data from all data bases summarized in the Results section of this report.

\section{A. Trinity Data Analysis: ${ }^{137} \mathrm{Cs}$ in Soil}

There are three independent modes of measurement of radionuclide content in Trinity soils used: (1) direct, in situ gamma, spectroscopy, (2) laboratory gamma spectroscopy of canned soil samples, and (3) laboratory radiochemical an zlysis of soil samples. (See Chapter 2 of this report for details.) There is only limited overlap of determination of specific radionuclides by these approaches. In the case of ${ }^{137} \mathrm{Cs}$, only in situ spectroscopy and laboratory spectroscopy of canned samples were applied: one providing inventory estimates and the other soil concentration data. In application, these two sources of information on ${ }^{137} \mathrm{Cs}$ inventory are not totally independent. The in situ measurement requires knowledge of

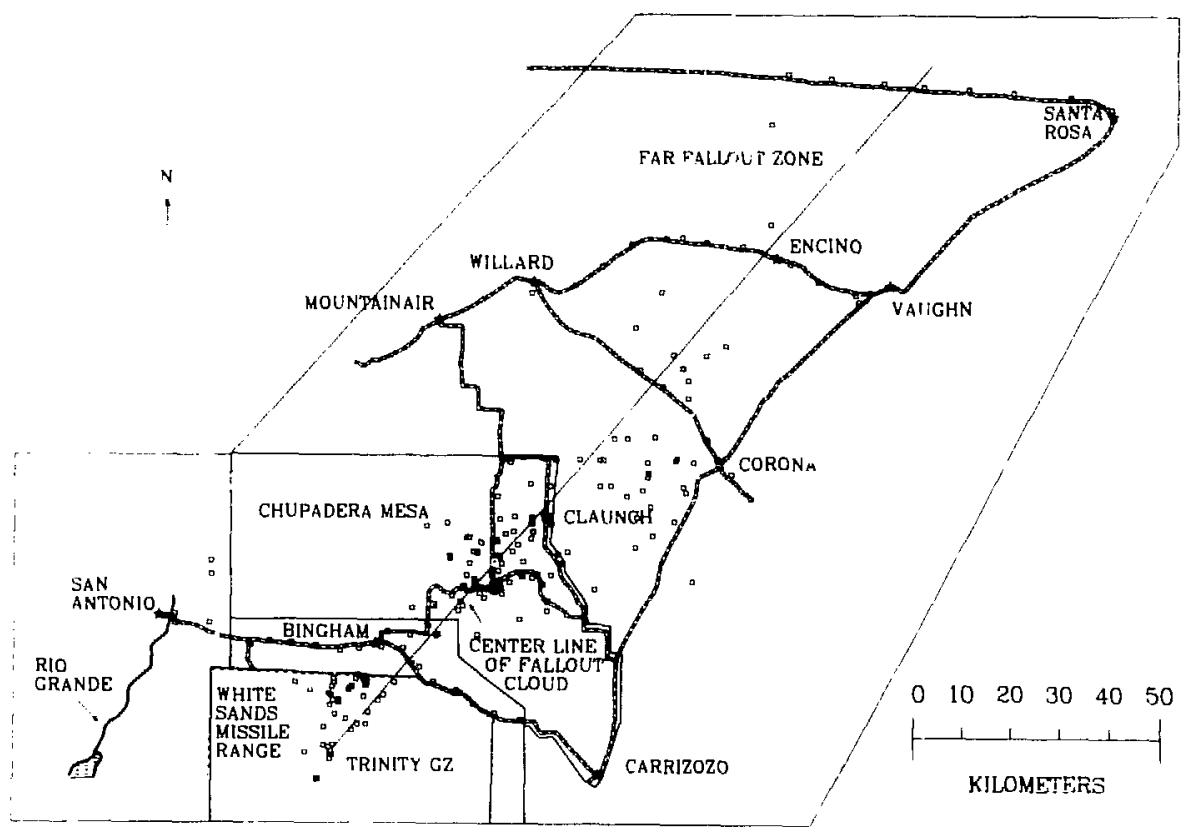

Fig. 7. General map of the Trinity fallout area and the measirement locations. 
the vertical distribution pattern in the soils in the vicinity of the detector in order to be translated into an inventory estimate. The soil sampling results can be used to provide this needed distribution estimate. A discussion of the reduction of these data to provide ${ }^{137} \mathrm{Cs}$ inventory estimates follows.

Soil samples were collected at a large number of locations throughout the survey area at locations where in situ spectroscopy measurernents were made (but not at every such location). Usually samples were collected at three consecutive 5 -cm depth intervals. However, when these samples were processed, not all samples were prepared and counted. Profiles for which complete or nearly complete ${ }^{137} \mathrm{Cs}$ concentration data exist are shown in Table III.

An estimate can be made of the ${ }^{137} \mathrm{Cs}$ concentration in those samples that were counted, but for which no cesium data were reported based on the minimum detectable activity (MDA). Using the MDA estimate in those instances where a sample was counted but no ${ }^{137} \mathrm{Cs}$ data were reported provides an upper-bound estimate of inventory. One approach to estimating the MDA for ${ }^{13 ?} \mathrm{Cs}$ is to examine the tren -1 in uncertainty in the reported data. The MDA can be taken to be the smallest amount of activity that would likely be reported with an error not greater than some acceptable limit, say $33 \%$. At an uncertainty of $33 \%$, the corresponding concentration is approximately $0.1 \mathrm{pCi} / \mathrm{g}$. Another approach based on statistical considerations, described in A.ppendix E, yields similar estimates.

Replacing MDA everywhere by the estimate of 0.1 $\mathrm{pCi} / \mathrm{g}$ substantially increases the number if protile estimates. The profile characterization is by means of an exponential fitting function:

$$
C=C_{o} \exp (-\alpha x)
$$

where $C$ is the concentration at depth $x, C_{0}$ is the surface concentration, and $\alpha$ is the inverse relaxation depth of the distribution. This relation can be justified theoretically on the basis of a simple box model in which the soil profile is characterized by a sequence of boxes that exchange contaminants over a period of time at a certain flow rate (A. T. Jakubide, Migration of Plutonium in Natural Soil, 1977). To incorporate the uncertainties in the concentration determinations into the profile characterization (that is, into the determination of the inverse relaxation depth estimate), a logarithmic transformation of Eq. (1) is made and the method of linear least squares applied with some modification to compensate for the fact that, unadjusted, the least-squares estimate underemphasizes the uncertainties for small values of C. (See Appendix C, least-squares fitting of an exponential function.)

The resulting alpha estimates for the Chupadera Mesa are shown in Table IV and GZ samples in Table V. Evidently, the mesa samples are characterized by a shallower profile (large alpha), and show less variability than the GZ samples do. This reflects, perhaps, the mechanical disturbance of $\mathrm{GZ}$ soils but also differences in the original deposition processes over these two areas, the geochemistry of the respective soils, and other environmental factors such as precipitation frequency, intensity, and so forth.

An estimate of the inventcry of ${ }^{137} \mathrm{Cs}\left(\mathrm{nCi} / \mathrm{m}^{2}\right)$ in these soils can be made utilizing the concentration and profile data. Since there can be expected considerable mixing in the topmost layer of soil, the average concentration at the midpoint in the 0 - to $5-\mathrm{cm}$ interval will be taken to be representative of the $0-$ to $2.5-\mathrm{cm}$ interval as well. (This estimation should tend to overestimate the actual inventory because there is most likely a parabolic distribution shape in the near surface layers caused from depletion processes at the surface.) Then the estimate of the inventory in the 0 - to $2.5-\mathrm{cm}$ interval is given, for a density of $1.5 \mathrm{~g} / \mathrm{cm}^{3}$, by

$$
\begin{aligned}
\mathrm{I}_{2.5} & =\mathrm{C}_{2.5}(\mathrm{pCi} / \mathrm{g}) \times 2.5 \mathrm{~cm} \times 1.5\left(\mathrm{~g} / \mathrm{cm}^{3}\right) \\
& \times 10^{4}\left(\mathrm{~cm}^{2} / \mathrm{m}^{2}\right) \times 10^{3}(\mathrm{nCi} / \mathrm{pCi})=37.5 \mathrm{C}_{2.5} .
\end{aligned}
$$

Then the total inventory can be estimateci over the rest of the profile assuming the fitted exponential distribution:

$$
\begin{aligned}
& I_{2.5-00} \\
& \quad=37.5 C_{2.5}+\left(\int_{2.5}^{\infty 0} \mathrm{e}^{-\mathrm{x}} \mathrm{dx}\right)(1.5)(1.0)\left(\mathrm{C}_{2.5}\right) \\
& \cong\left(37.5+\frac{15}{a}\right) \mathrm{C}_{2.5} \pm \sqrt{\frac{\sigma_{\mathrm{c}}^{2}}{\mathrm{C}^{2}}+\frac{\sigma a^{2}}{a^{2}}},
\end{aligned}
$$

where the integral is approximated by one-half.

A comparison of the in situ inventory estimates with many of the soil sample estimates is possible and provides some measure of the compatibility of these two approaches to inventory estimation (Table VI). Because of delays in processing of canned soil samples, assignment of the $\alpha$ profile parameter for each sample location had to 
TABLE III

${ }^{137} \mathrm{Cs}$ SCIL CONCENTRATION DATA

\section{Location}

\begin{tabular}{|c|c|c|c|c|c|c|c|}
\hline \multirow{2}{*}{$\begin{array}{l}\text { GZ or } \\
\text { Mesa }\end{array}$} & \multirow{2}{*}{$\begin{array}{l}\text { LADB }^{a} \\
\text { No. }\end{array}$} & \multicolumn{6}{|c|}{ Concentration $(\mathrm{pCi} / \mathrm{g})$} \\
\hline & & $0.5 \mathrm{~cm}$ & FSD $^{b}$ & $5.10 \mathrm{~cm}$ & FSD & $10-.15 \mathrm{~cm}$ & FSD \\
\hline G & 1990 & 13.6 & 0.011 & 21.7 & 0.013 & 6.98 & 0.036 \\
\hline$G$ & 1991 & 6.04 & 0.036 & 9.26 & 0.014 & $-\mathrm{c}^{\mathrm{c}}$ & --- \\
\hline$G$ & 1988 & 0.61 & 0.486 & 24.95 & 0.024 & $\cdots$ &.-- \\
\hline G & 1989 & 1.75 & 0.122 & 0.17 & 0.179 & $\mathrm{MDA}^{\mathrm{d}}$ & $\cdots$ \\
\hline$G$ & 2006 & 0.35 & 0.188 & 0.28 & 0.185 & --- & --- \\
\hline G & 2005 & 0.77 & 0.031 & 0.52 & 0.032 & -.. & -- \\
\hline G & 2012 & 0.38 & 0.227 & 0.41 & 0.127 & MDA & MDA \\
\hline G & 2016 & 0.82 & 0.032 & 0.26 & 0.24 & 0.11 & 0.164 \\
\hline $\mathbf{G}$ & 2018 & 0.26 & 0.173 & 0.26 & 0.058 & 0.15 & 0.355 \\
\hline G & 2014 & 0.99 & 0.033 & -- & --- & 0.97 & 0.059 \\
\hline G & 2019 & 0.54 & 0.057 & 0.38 & 0.108 & 0.14 & 0.299 \\
\hline $\mathbf{M}$ & 2027 & 3.19 & 0.017 & 0.12 & 0.135 & 0.21 & 0.155 \\
\hline M & 2026 & 5.42 & 0.063 & 0.48 & 0.097 & MDA & MDA \\
\hline $\mathbf{M}$ & 2045 & 1.18 & 0.034 & 0.22 & 0.085 & 0.08 & 0.224 \\
\hline M & 2048 & i. .08 & 0.047 & 0.13 & 0.274 & 0.19 & 0.296 \\
\hline G & 1987 & 1.87 & 0.11 & 0.16 & 0.291 & MDA & MDA \\
\hline $\mathbf{M}$ & 2053 & 0.71 & 0.056 & --- & --- & 0.06 & 0.204 \\
\hline $\mathbf{M}$ & 2050 & 0.79 & 0.025 & - & --- & 0.28 & 0.221 \\
\hline $\mathbf{M}$ & 2057 & 2.56 & 0.017 & --- & --- & MDA & MDA \\
\hline $\mathbf{M}$ & 2049 & 0.83 & 0.052 & -- & -.- & MDA & MDA \\
\hline M & 2115 & 2.95 & 0.027 & 0.09 & 0.192 & MDA & MDA \\
\hline M & 2116 & 5.42 & 0.013 & 0.48 & 0.097 & MDA & MDA \\
\hline $\mathbf{M}$ & 2118 & 2.06 & 0.03 & 0.10 & 0.162 & MDA & MDA \\
\hline $\mathbf{M}$ & 2081 & 1.29 & 0.032 & -- & --- & MDA & MDA \\
\hline $\mathbf{M}$ & 2080 & 0.32 & 0.081 & --- & --- & 0.11 & 0.163 \\
\hline $\mathrm{G}$ & 1992 & 0.10 & 0.344 & 0.18 & 0.282 & --- & -.- \\
\hline $\mathbf{M}$ & 2120 & 1.75 & 0.030 & 1.0 & 0.040 & MDA & MDA \\
\hline M & 2071 & 3.12 & 0.02 & $\cdots$ & $\cdots$ & 0.14 & 0.35 \\
\hline $\mathbf{M}$ & 2058 & 5.14 & 0.01 & --. & --- & 0.08 & 0.34 \\
\hline$M$ & 2028 & 5.87 & 0.01 & 0.18 & 0.29 & MDA & MDA \\
\hline $\mathbf{M}$ & 2059 & 1.04 & 0.04 & --- & -- & MDA & MDA \\
\hline
\end{tabular}

${ }^{a}$ LADB - Los Alamos Data Base.

${ }^{b}$ FSD - Fractional Standard Deviation.

c--- means no data taken.

dMDA - Minimum Detectable Activity. 
TABLE IV

\section{CHUPADERA MESA ${ }^{137}$ Cs PROFILE DATA}

\begin{tabular}{|c|c|c|c|c|c|}
\hline $\begin{array}{l}\text { LADB }^{\mathrm{a}} \\
\text { No. }\end{array}$ & $\begin{array}{c}\mathrm{C} \\
\text { Conc at } \\
2.5 \mathrm{~cm} \\
(\mathrm{pCl} / \mathrm{g})\end{array}$ & $\operatorname{FSD}(\mathbf{B})^{\mathrm{b}}$ & $\alpha\left(\mathrm{cm}^{-1}\right)$ & $\operatorname{FSD}(\alpha)$ & Sequenc \\
\hline $20^{\prime} 6$ & 5.42 & 0.013 & 0.33 & 0.64 & 0.4 \\
\hline $202 \%$ & 3.19 & 0.017 & 0.33 & 0.09 & 0.2 \\
\hline 2028 & 5.87 & 0.010 & 0.53 & 0.16 & 0.4 \\
\hline 2045 & 1.18 & 0.034 & 0.32 & 0.10 & 0.2 \\
\hline 2048 & 1.08 & 0.047 & 0.22 & 0.29 & 0.4 \\
\hline 2049 & 0.83 & 0.052 & 0.22 & 0.50 & 0.2 \\
\hline 2050 & 0.79 & 0.025 & 0.10 & 0.40 & 0.2 \\
\hline 2053 & 0.71 & 0.056 & 0.25 & 0.32 & 0.2 \\
\hline 2057 & 2.56 & 0.017 & 0.33 & 0.33 & 0.4 \\
\hline 2058 & 5.14 & 0.010 & 0.42 & 0.29 & 0.4 \\
\hline 2059 & 1.04 & 0.040 & 0.24 & 0.45 & 0.4 \\
\hline 2071 & 6.87 & 0.020 & 0.39 & 0.23 & 0.4 \\
\hline 2080 & 0.32 & 0.081 & 0.11 & 0.48 & 0.2 \\
\hline 2081 & 0.29 & 0.032 & 0.27 & 0.41 & 0.4 \\
\hline 2115 & 2.95 & 0.027 & 0.49 & 0.17 & 0.7 \\
\hline 2116 & 5.42 & 0.013 & 0.48 & 0.06 & 0.7 \\
\hline 2118 & 2.C6 & 0.030 & 0.47 & 0.16 & 0.7 \\
\hline
\end{tabular}

Note: Mean $\alpha=0.3235$ and $\sigma=0.1281$.

${ }^{\text {a }}$ AADB - Los Alamos Data Base.

${ }^{b}$ FSD - Fractional Standard Deviation.

be made on the basis of limited information. Thus, there are a number of significant differences between the assumed $\alpha$ for in situ estimation and the fitted $\alpha$ for soil sample estimation (Table VII). However, corrected in situ estimates of inventory based on detector efficiencies as a function of $a$ (Chapter II) were made corresponding to fitted $\alpha$ 's and are shown in column 5 of Table VII.

Figure 8, a plot of soil-sample gamma in situ inventory estimates, suggests that the two estimation procedures yield similar results. A paired t-test was calculated for both corrected and uncorrected data (excluding sample 2014 , which is a GZ sample), with the result that the two sample means are not significantly different at the $90 \%$ confidence limit in either the corrected or uncorrected cases. The a parameter correction appears to makc only a small difference in comparability. Possibly the fact that the in situ technique is averaging over a considerably larger volume of soil at each sampling location than the corresponding soil samples is a compensating effect to the uncertainties in estimating $\alpha$.

Thus, it would appear that the in situ ${ }^{137} \mathrm{Cs}$ total inventory estimates are comparable with soil sampling estimates with an uncertainty on the order of $50 \%$. 
GROUND ZERO TO CHUPADERA MESA ${ }^{13}$ 'Cs PROFILE DATA

Conc at

\begin{tabular}{|c|c|c|c|c|}
\hline $\begin{array}{l}\text { LADB }^{a} \\
\text { No. }\end{array}$ & $\begin{array}{l}2.5 \mathrm{~cm} \\
(\mathrm{pCi} / \mathrm{g})\end{array}$ & $\operatorname{FSD}(C)^{b}$ & $\alpha\left(\mathrm{cm}^{-1}\right)$ & $\operatorname{FSD}(\alpha)$ \\
\hline 1987 & 1.87 & 0.11 & 0.37 & 0.24 \\
\hline 1988 & 0.61 & 0.486 & 0.12 & 0.17 \\
\hline 1989 & 1.75 & 0.122 & 0.40 & 0.07 \\
\hline 1990 & 13.60 & 0.011 & 0.06 & 0.01 \\
\hline 1991 & 6.04 & 0.036 & 0.08 & 0.04 \\
\hline 1992 & 0.10 & 0.344 & 0.12 & 2.17 \\
\hline 2005 & 0.77 & 0.031 & 0.08 & 0.14 \\
\hline 2006 & 0.35 & 0.188 & 0.04 & 2.12 \\
\hline 2012 & 0.38 & 0.227 & 0.03 & 2.51 \\
\hline 2014 & 0.99 & 0.033 & 0.002 & 0.006 \\
\hline 2016 & 0.82 & 0.032 & 0.21 & 0.21 \\
\hline 2018 & 0.26 & 0.173 & 0.02 & 4.27 \\
\hline 2019 & 0.54 & 0.057 & 0.08 & 0.43 \\
\hline
\end{tabular}

${ }^{a}$ LADB - Los Alamos Data Base.

${ }^{b}$ FSD - Fractional Standard Deriation.

\section{B. Trinity Data Analysis: ${ }^{239,240} \mathrm{Pu}$ in Soil}

Direct determination of the concentration and inventory of plutonium in Trinity soils was carried out by soil sampling and radiochemical analyses. Preliminary investigation of the possibility of utilizing the determination of ${ }^{241} \mathrm{Am}$ inventory as an indirect means of determining ${ }^{239.240} \mathrm{Pu}$ inventory proved unsuccessful because of an observed very low concentration of ${ }^{241} \mathrm{Am}$ in the Trinity soils, even in the vicinity of GZ.

The soil radiochemical results are tabulated in Table VIII. These data indicate a fairly rapid decrease in plutonium concentration with depth in most cases. But there are some significant exceptions such as at sample location 2072, which is a flat, grassy sediment trap on Chupadera Mesa. Here, relatively high concentrations $(>1 \mathrm{pCi} / \mathrm{g}$ ) persist to a depth of 10 to $15 \mathrm{~cm}$. Deep distribution of plutonium might be expected to occur in such sediment traps; however, no systematic attempt was

\section{${ }^{137} \mathrm{Cs}$ INVENTORY ESTIMATES}

\section{A. Chupadera Mesa}

\begin{tabular}{|c|c|c|c|c|}
\hline $\begin{array}{l}\text { LADB }^{a} \\
\text { No. }\end{array}$ & $\begin{array}{c}\text { l-cm } \\
\text { Inventory } \\
\left(\mathrm{nCi} / \mathrm{m}^{2}\right)\end{array}$ & FSD & $\begin{array}{c}\text { Total } \\
\text { Inventory } \\
\left(\mathrm{nCim}^{2}\right)\end{array}$ & FSD $^{b}$ \\
\hline 2026 & 81.3 & 0.013 & 449.6 & 0.64 \\
\hline 2027 & 47.85 & 0.017 & 264.6 & 0.09 \\
\hline 2028 & 88.05 & 0.010 & 386.3 & 0.18 \\
\hline 2045 & 17.70 & $\dot{u} .034$ & 99.56 & 0.11 \\
\hline 2048 & 16.20 & 0.047 & 114.1 & 0.29 \\
\hline 2049 & 12.45 & 0.052 & 87.7 & 0.50 \\
\hline 2050 & 11.85 & 0.025 & 148.1 & 0.40 \\
\hline 2053 & 10.65 & 0.056 & 69.2 & 0.32 \\
\hline 2057 & 38.4 & 0.017 & 212.4 & 0.33 \\
\hline 2058 & 177.1 & 0.01 & 376.3 & 0.39 \\
\hline 2059 & 15.6 & 0.04 & 104.0 & 0.45 \\
\hline 2071 & 103.05 & 0.02 & 521.9 & 0.23 \\
\hline 2080 & 4.89 & 0.081 & 55.6 & 0.48 \\
\hline 2081 & 19.35 & 0.032 & 120.0 & 0.41 \\
\hline 2115 & 44.25 & 0.027 & 200.9 & 0.17 \\
\hline 2116 & 81.30 & 0.013 & 372.6 & 0.06 \\
\hline 2118 & 30.90 & 0.030 & 142.9 & 0.16 \\
\hline
\end{tabular}

B. GZ to Chupadera Mesa

$\begin{array}{lclcl}1987 & 28.05 & 0.11 & 145.9 & 0.26 \\ 1988 & 9.15 & 0.49 & 99.1 & 0.51 \\ 1989 & 26.25 & 0.12 & 131.25 & 0.20 \\ 1990 & 204.0 & 0.01 & 3710.0 & 0.01 \\ 1991 & 90.6 & 0.036 & 1359.0 & 0.05 \\ 1992 & 1.5 & 0.344 & 16.25 & 2.17 \\ 2005 & 11.55 & 0.031 & 173.25 & 0.14 \\ 2006 & 5.25 & 0.188 & 144.4 & 3.1 \\ 2012 & 5.70 & 0.227 & 204.3 & 0.23 \\ 2014 & .14 .85 & 0.033 & 7462.1 & 0.03 \\ 2016 & 12.30 & 0.032 & 89.32 & 0.21 \\ 2018 & 3.90 & 0.173 & 204.75 & 4.2 \\ 2019 & .8 .10 & 0.057 & 121.5 & 0.43\end{array}$

${ }^{a}$ LADB - Los Alamos Data Base.

${ }^{\mathrm{b}} \mathrm{FSD}$ - Fractional Standard Deviation. 
TABLE VII

\section{COMPARISON OF IN SITU AND SOIL SAMPLE ESTIMATES OF ${ }^{137} \mathrm{C} s$ TOTAL INVENTORY $\left(\mathrm{nCi} / \mathrm{rn}^{2}\right)$}

\begin{tabular}{|c|c|c|c|c|c|c|c|}
\hline $\begin{array}{l}\text { LADB }^{8} \\
\text { No. }\end{array}$ & $\begin{array}{c}\text { Assumed } \\
\alpha\end{array}$ & $\begin{array}{l}\text { Inventory } \\
\text { In Situ } \\
\text { Reported }\end{array}$ & $\sigma$ & $\begin{array}{l}\text { Inventory } \\
\text { Corrected } \\
\text { for } \alpha \\
\end{array}$ & $\begin{array}{c}\text { Irventory } \\
\text { Soil Sample } \\
\text { Estimate }\end{array}$ & $\mathrm{FSD}^{\mathrm{C}}$ & $\begin{array}{c}\text { Measured } \\
\alpha\end{array}$ \\
\hline 2012 & 0.2 & 236.6 & 5.73 & 701.3 & 204.3 & 0.23 & 0.03 \\
\hline 2014 & 0.03 & 858.2 & 25.29 & 1501.9 & 7462.1 & 0.03 & 0.002 \\
\hline 2016 & 0.20 & 84.58 & 4.46 & 84.6 & 89.3 & 0.21 & 0.21 \\
\hline 2018 & 0.20 & 90.92 & 2.96 & 269.5 & 204.8 & 0.17 & 0.02 \\
\hline 2019 & 0.20 & 26.43 & 1.19 & 99.7 & $\mathrm{i} 21.5$ & 0.10 & 0.08 \\
\hline 2026 & 0.40 & 540.0 & 49.28 & 597.9 & 449.6 & 0.64 & 0.33 \\
\hline 2027 & 0.20 & 314.0 & 4.74 & 232.7 & 264.6 & 0.09 & 0.33 \\
\hline 2049 & 0.20 & i 39.6 & 3.53 & 139.6 & 87.7 & 0.50 & 0.22 \\
\hline 2050 & 0.20 & 125.2 & 3.43 & 185.6 & 148.1 & 0.40 & 0.10 \\
\hline 2053 & 0.20 & 189.0 & 4.01 & 189.0 & 69.2 & 0.32 & 0.25 \\
\hline 2057 & 0.40 & 158.7 & 3.04 & 175.7 & 212.4 & 0.33 & 0.33 \\
\hline 2058 & 0.40 & 323.4 & 4.22 & 323.4 & 376.3 & 0.29 & 0.42 \\
\hline 2059 & 0.40 & 211.3 & 3.40 & 284.8 & 104.0 & 0.45 & 0.24 \\
\hline 2071 & 0.40 & 388.7 & 5.35 & 388.7 & 521.9 & 0.23 & 0.39 \\
\hline 2080 & 0.20 & 81.5 & $2.9 \mathrm{I}$ & 120.8 & 55.6 & 0.48 & 0.11 \\
\hline 2081 & 0.40 & 135.5 & 2.74 & $\mathrm{I} 68.0$ & 120.0 & 0.41 & 0.27 \\
\hline 2115 & 0.70 & 83.7 & 2.12 & 98.3 & 200.9 & 0.17 & 0.49 \\
\hline 2116 & 0.70 & 84.4 & 2.23 & 98.7 & 372.6 & 0.06 & 0.48 \\
\hline 2118 & 0.70 & 100.0 & 2.23 & 120.9 & 142.9 & 0.16 & 0.47 \\
\hline
\end{tabular}

${ }^{a}$ LADB - Los Alamos Data Base.

${ }^{b}$ The number of counts in the ${ }^{137} \mathrm{Cs}$ photopeak is converted to $\mathrm{nCi} / \mathrm{m}^{2}$ by a detector efficiency term $\mathrm{N}_{\mathrm{f}} / \mathrm{s}$, which is a' 'iction of $\alpha$. The ratio of the efficiency values for the assumed $\alpha$ and actual measured $\alpha$ from profile data vas used to evaluate a corrected in situ estimate.

${ }^{\mathrm{c} F S D}$ - Fractional Standard Deviation.

made to fully explore the extent of vertical redistribution of plutonium in soils.

As in the case of ${ }^{137} \mathrm{Cs}$ soil concentrations profile data, these plutonium data can be fitted by an exponential distribution model in most cases to provide an estimate of discribution with depth, and thereby, inventory. Lea itsquares fitting of these data (where possible) with an exponential fitting function yield the results tabulated in Table IX.

These profile characterizations clsarly point to the highly variable or indeterminate distribution conditions of the GZ area due pcssibly to mechanical disturbance in the characteristics of the fallout materials, and so forth. The fit of the shapes of the concentration depth profiles to an exponential function is reasonably good on Chupadera Mesa; but there are some notable exceptions. Some of the cases where there is considerable uncertainty in the profile parameter $\alpha$ are probably attributable to very low concentrations, especially at greatest depth, with consequent poor recovery and counting statistics. Others (sample 2080, for example) may reflect other processes at 


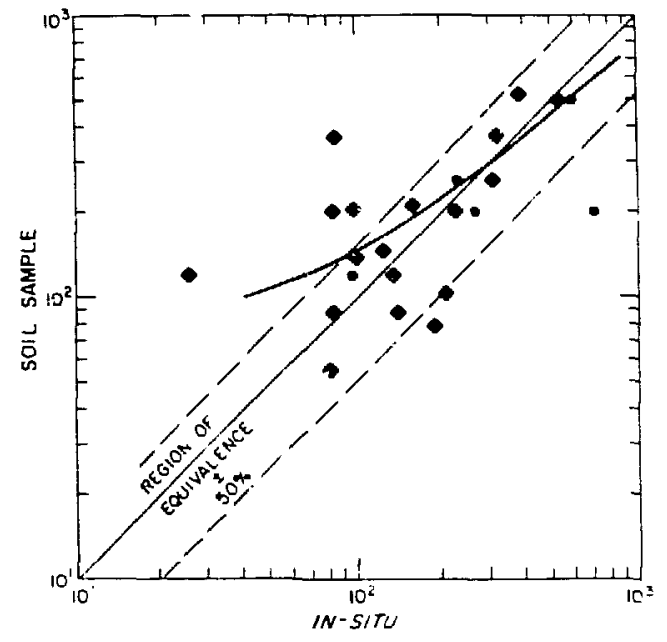

Fig. 8. Comparison of in situ and soil sample estimates of total ${ }^{137}$ Cs inventory.

work affecting vertical redistribution rather than infiltration, such as disturbances by burrowing rodents, cattle, or big game animals.

Concentrations of ${ }^{238} \mathrm{Pu}$ in these soils are so fow as to make reliable estimates of profile distributions, and consequently total inventory, impossible. Table $\mathrm{X}$ illustrates the order of magnitude of some surface $(0-$ to $5-\mathrm{cm})$ concentrations and corresponding ${ }^{238} \mathrm{Pu} /{ }^{239} \mathrm{Pu}$ ratios. There is apparently about 20 times more ${ }^{239} \mathrm{Pu}$ than ${ }^{238} \mathrm{Pu}$ in the surface soils, independent of location.

The ${ }^{239,240} \mathrm{Pu}$ inventory estimate was made utilizing the same strategy as was used for ${ }^{137} \mathrm{Cs}$ inventory estimates, that is, by assuming an essentially uniform concentration in the $0-$ to $2.5-\mathrm{cm}$ layer, and a decreasing exponential distribution over the remainder of the profile. On these assumptions, the 0 - to $1-\mathrm{cm}$ inventory $I_{1}$ (most readily available for resuspension) and the total inventory $I_{T}$ estimates are given, assuming again a density of 1.5 $\mathrm{g} / \mathrm{cm}^{3}$,

$I_{I} \cong 15 C_{2.5} \pm \sigma_{c}$

and

$\mathrm{I}_{\mathrm{T}} \cong\left(37.5+\frac{15}{\alpha}\right) \mathrm{C}_{2.5} \pm \sqrt{\frac{\mathrm{C}^{2}}{\sigma \mathrm{c}^{2}}+\frac{\alpha^{2}}{\sigma_{a}^{2}}}$.
These two inventories are tabulated in Table XI for those cases where adequate data exist. Samples for which either the profile estimate could not be made or for which the uncertainty in the surface concentration and/or profile $\alpha$ estimates were too great to provide useful total inventory estimates, still have a surface inventory estimate listed. Evidently in the case of GZ environs samples, only the near surface inventory estimate is usable.

\section{Other Fission and Activation Products in Soils}

In addition to cesium and plutonium, several yission products and activation products from the Trinity event and more recent Chinese nuciear tests were detected by the $\mathrm{Ge}(\mathrm{Li})$ systems used. The activation and fission products from the relatively recent fallout were detectable at most locations by observing the ${ }^{95} \mathrm{Zr}$ and ${ }^{95} \mathrm{Nb}$ gamma rays in the in situ spectra. The average ${ }^{95} \mathrm{Zr}$ (half-life, 64 d) ${ }^{22}$ areal concentration for the approximately $2500 \mathrm{mi}^{2}$ surveyed was $2.4 \pm 0.12 \mathrm{nCi} / \mathrm{m}^{2}$ and the ${ }^{93} \mathrm{Nb}$ (half-life. $35.1 \mathrm{~d})^{22}$ average concentration was $3.8 \pm 0.15 \mathrm{nCi} / \mathrm{m}^{2}$. The range of concentrations was from undetectable to 6.6 $\mathrm{nCi} / \mathrm{m}^{2}$ for ${ }^{95} \mathrm{Nb}$. Of the 116 measurement locations for ${ }^{137} \mathrm{Cs},{ }^{95} \mathrm{Zr}$ was detected at 88 locations and ${ }^{95} \mathrm{Nb}$ at 92 locations.

Other short-lived radionuclides detected by the in situ $\mathrm{Ge}(\mathrm{Li})$ system were ${ }^{7} \mathrm{Be}$ and ${ }^{103} \mathrm{Ru}$. The relatively short half-lives of $53.4 \mathrm{~d}^{22}$ for ${ }^{7} \mathrm{Be}$ and $39.3 \mathrm{~d}^{22}$ for ${ }^{103} \mathrm{Ru}$ also identify these radionuclides as being part of fallout from the 4-megaton Chinese nuclear test on November 17, 1976. ${ }^{7}$ The ${ }^{7} \mathrm{Be}$ concentration on an areal basis averaged $8.1 \pm 0.7 \mathrm{nCi} / \mathrm{m}^{2}$ with a range from undetected to 26 $\mathrm{nCi} / \mathrm{m}^{2}$. Of the 116 locations monitored for ${ }^{137} \mathrm{Cs}, 62$ locations had detectable ${ }^{7} \mathrm{Be}$. Only 22 out of the 116 locations contained detectable ${ }^{103} \mathrm{Ru}$ with concentrat.ons for the area surveyed averaging $0.21 \pm 0.04 \pi \mathrm{ni} / \mathrm{m}^{2}$. The range was from undetectable quantities to $1.9 \mathrm{nCi} / \mathrm{m}^{2}$.

The in situ gamma spectra and laboratory analyses of soil indicated the presence of the activation and fission products ${ }^{60} \mathrm{Co},{ }^{152} \mathrm{Eu}$, and ${ }^{135} \mathrm{Eu}$. Because of the longer half-lives associated with these radionuclides, the quantities present are considered to be from the Trinity tesi. The half-life of ${ }^{60} \mathrm{Co}$ is $5.27 \mathrm{yr} ;{ }^{152} \mathrm{Eu}, 14 \mathrm{yr}$; and ${ }^{155} \mathrm{Eu}, 5$ $\mathrm{yr}^{22}$ The areal concentration of these radionuclides at two GZ locations as measured by in situ methods indicated $5000 \mathrm{nCi} / \mathrm{m}^{2}$ and $50 \mathrm{nCi} / \mathrm{m}^{2}$ of ${ }^{60} \mathrm{Co}$ and $\mathrm{i} . \mathrm{I} \times$ $10^{4} \mathrm{nCi} / \mathrm{m}^{2}$ and $1.2 \times 10^{3} \mathrm{nCi} / \mathrm{m}^{2}$ of ${ }^{155} \mathrm{Eu}$. For areas 
TABLE VIII

TRINITY SOI: CONCENTRATION OF ${ }^{239,240} \mathrm{Pu}$

Location LADB $^{A}$ GZ or

No. diesa (M)

1998

$$
199
$$

2000

2009

2014

2010

2018

2026

2027

2028

20.37

2047

$2052^{*}$

2048

\section{9}

2057

2059

2060

2065

2071

2072

2073

2076

2080

2082

2084

2096

2097

2115

2118

2119

2120

2121

\begin{tabular}{|c|c|c|c|c|c|c|c|c|c|}
\hline \multicolumn{10}{|c|}{ Activity $(\mathbf{p C i} / g)$} \\
\hline $0.5 \mathrm{~cm}$ & FSD $^{\text {h }}$ & $3.10 \mathrm{~cm}$ & FSD & $10.19 \mathrm{~cm}$ & FSD & $15.20 \mathrm{~cm}$ & FSD & $2025 \mathrm{~cm}$ & FSD \\
\hline 24.3 & 0.02 & 57.4 & 0.02 & 0.15 & 0.47 & $\ldots c$ & $\cdots$ & $\cdots$ & - \\
\hline 64.9 & 0.02 & 44.4 & 0.02 & 201 & 0.01 & $\cdots$ & $\cdots$ & $\cdots$ & $\cdots$ \\
\hline 3.8 & 0.05 & 0.05 & 0.80 & -0.06 & 0.67 & $\cdots$ & $\cdots$ & $-\cdots$ & .. \\
\hline 0.48 & 0.04 & 0.45 & 0.04 & 0.47 & 0.04 & $\cdots$ & $\cdots$ & .. & $\cdots$ \\
\hline 0.165 & 0.05 & 0.71 & 0.03 & 0.146 & 0.86 & $\cdots$ & $\cdots$ & -. & $\cdots$ \\
\hline 0.122 & 0.08 & $\cdots$ & $\cdots$ & -0.68 & 0.04 & -- & $\cdots$ & $\cdots$ & $\cdots$ \\
\hline 0.67 & 0.04 & $-0.601^{d}$ & 2.0 & $\cdots$ & $\cdots$ & $\cdots$ & $\cdots$ & $\cdots$ & $\cdots$ \\
\hline 3.51 & 0.03 & 0.118 & 0.07 & 0.018 & 0.22 & $\ldots$ & $\cdots$ & $\cdots$ & $\cdots$ \\
\hline 1.71 & 0.03 & 0.204 & 0.05 & 0.074 & 0.08 & --- & -- & ... & $\cdots$ \\
\hline 4.07 & 0.04 & 0.109 & 0.06 & 0.007 & 0.28 & $\cdots$ & $\cdots$ & $\cdots$ & $\cdots$ \\
\hline 1.83 & $0 ?$ & 0.082 & 0.06 & $\cdots$ & $\cdots$ & $\cdots$ & $\cdots$ & $\cdots$ & $\cdots$ \\
\hline 0.98 & 6.04 & 0.241 & 0.06 & 0.172 & 0.05 & 0.013 & 0.231 & 0.007 & 0.29 \\
\hline 0.122 & 0.07 & 0.004 & 0.75 & 0.010 & 0.0001 & 0.0017 & 0.71 & $\cdots$ & $\cdots$ \\
\hline 0.398 & 0.058 & 0.019 & 0.168 & 0.0059 & 0.32 & $\cdots$ & $\cdots$ & $\cdots$ & $\cdots$ \\
\hline 0.246 & 0.04 & $\ldots$ & $\ldots$ & 0.001 & 1.55 & $\cdots$ & $\cdots$ & 0.002 & 1.50 \\
\hline 0.70 & 0.03 & 0.383 & 0.05 & 0.01 & 0.0001 & $\omega$ & $\cdots$ & $\cdots$ & $\cdots$ \\
\hline 1.21 & 0.06 & 0.033 & 0.15 & 0.018 & 0.17 & $\cdots$ & $\cdots$ & $\cdots$ & $\cdots$ \\
\hline 1.06 & 0.04 & 0.302 & 0.04 & 0.157 & 0.08 & 0.088 & 0.10 & 0.053 & 0.01 \\
\hline 0.271 & 0.04 & 0.002 & 0.71 & -0.001 & 1.29 & $\cdots$ & $\cdots$ & $\cdots$ & $\cdots$ \\
\hline 1.54 & 0.03 & $\cdots$ & $\cdots$ & 0.061 & 0.10 & $\cdots$ & $\cdots$ & $\cdots$ & $\cdots$ \\
\hline 4.58 & 003 & 3.88 & 0.03 & 1.15 & 0.03 & --- & $\cdots$ & $-\cdot$ & $\cdots$ \\
\hline 6.70 & 0.03 & $\cdots$ & $\ldots$ & $\ldots$ & $\ldots$ & $\ldots$ & $\cdots$ & $\cdots$ & $\cdots$ \\
\hline 0.435 & 0.03 & 0.018 & 0.17 & 0.016 & 0.09 & $\cdots$ & $\cdots$ & .. & $\cdots$ \\
\hline 0.027 & 0.15 & 0.024 & 0.17 & 0.016 & 0.19 & $\cdots$ & $\cdots$ & $\cdots$ & $\cdots$ \\
\hline 0.95 & 0.04 & 0.010 & 0.20 & $-0.00 i$ & 1.0 & $\cdots$ & $\cdots$ & $\cdots$ & $\cdots$ \\
\hline 1.23 & 0.04 & 0.056 & 0.11 & 0.009 & 0.44 & $\cdots$ & $\cdots$ & $\cdots$ & $\cdots$ \\
\hline 0.213 & 0.06 & 0.002 & 1.50 & -0.003 & 1.0 & $\cdots$ & $\cdots$ & $\ldots$ & . \\
\hline 0.61 & 0.05 & 0.153 & $0 . n 4$ & 0.007 & 0.43 & $\cdots$ & --- & 0.002 & 0.94 \\
\hline 0.25 & 0.16 & 0.021 & 0.19 & 0.0013 & 1.15 & $--\cdot$ & $\cdots$ & $\cdots$ & .. \\
\hline 0.18 & 0.07 & 0.013 & 0.23 & 0.001 & 4.0 & $--\cdot$ & $\cdots$ & $--\cdot$ & $\cdots$ \\
\hline 0.17 & 0.06 & -0.01 & 2.0 & 0.005 & 1.0 & --- & $\cdots$ & $\cdots$ & $\cdots$ \\
\hline 0.23 & 0.13 & 0.60 & 0.05 & 0.037 & 0.14 & $\cdots$ & --- & $\cdots$ & $\cdots$ \\
\hline 0.69 & 0.04 & 0.51 & 0.04 & -.- & $\cdots$ & $\ldots$ & -- & 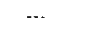 & $\cdots$ \\
\hline
\end{tabular}

LADB - Los Alamos Dala Base.

FSD is the standard deviation of the measured value divided by the measured value.

Blanks indicate that sample was not taken or not analyzed.

Additional profiles: $25.30 \mathrm{crn}, 0.007$ (1.8) pCi/g; $30-35 \mathrm{~cm} .0 .0023(0.61) \mathrm{pCi} / \mathrm{g}: 40-45 \mathrm{~cm}, 0.0075(0.25) \mathrm{pCi} / \mathrm{g}$

Negative values represen observations smaller than chemical blank values. 
TABLE IX

GZ ENVIRONS AND

CHUPADERA MESA ${ }^{239,240} \mathrm{Pu}$ SOIL CONCENTRATION PROFILE ESTIMATES

\begin{tabular}{|c|c|c|c|c|}
\hline \multirow{3}{*}{$\begin{array}{l}\text { LADB }^{\mathrm{a}} \\
\text { No. }\end{array}$} & \multicolumn{2}{|c|}{$\begin{array}{l}\text { Surface Soil } \\
\text { Concentration } \\
\end{array}$} & \multirow{2}{*}{\multicolumn{2}{|c|}{$\begin{array}{c}\text { Inverse Relaxation } \\
\text { Depth of Profile } \\
\end{array}$}} \\
\hline & \multirow{2}{*}{$\begin{array}{l}\mathrm{C}=\text { Conc } \\
\text { at } 2.5 \mathrm{~cm} \\
(\mathrm{pCi} / \mathrm{g})\end{array}$} & \multirow[b]{2}{*}{$\operatorname{FSD}(C)^{b}$} & & \\
\hline & & & $\alpha\left(\mathrm{cm}^{-1}\right)$ & $\operatorname{FSD}(\alpha)^{b}$ \\
\hline 1995 & \multicolumn{4}{|c|}{ (uniformly uncontaminated at background) } \\
\hline 1998 & \multicolumn{4}{|c|}{ ( $\alpha$ indeterminate-disturbed soil at GZ) } \\
\hline 2001 & \multicolumn{4}{|c|}{ (a positive-distlirbed soil GZ) } \\
\hline 2003 & 3.8 & 0.05 & 0.86 & 16.5 \\
\hline 2009 & 0.48 & 0.04 & 0.001 & 12.9 \\
\hline 2016 & \multirow{2}{*}{\multicolumn{4}{|c|}{$\begin{array}{l}\text { (a positive-disturbed soil) } \\
\text { ( } \alpha \text { indeterminate-surface deposit only) }\end{array}$}} \\
\hline 2018 & & & & \\
\hline 2026 & 3.51 & 0.03 & 0.67 & 0.06 \\
\hline 2027 & 1.71 & 0.03 & 0.38 & 0.05 \\
\hline 2028 & 4.07 & 0.04 & 0.72 & 0.05 \\
\hline 2037 & 1.83 & 0.03 & 0.62 & 0.07 \\
\hline 2047 & 0.98 & 0.04 & 0.19 & 0.06 \\
\hline 2048 & 0.39 & 0.05 & 0.56 & 0.36 \\
\hline 2049 & 0.25 & 0.04 & 0.28 & 5.74 \\
\hline 2052 & 0.12 & 0.07 & 0.25 & 0.09 \\
\hline 2057 & 0.70 & 0.03 & 0.34 & 0.03 \\
\hline 2059 & 1.21 & 0.06 & 0.53 & 0.19 \\
\hline 2060 & 1.06 & 0.04 & 0.19 & 0.05 \\
\hline 2065 & 0.27 & 0.04 & 1.01 & 3.38 \\
\hline 2071 & 1.54 & 0.03 & 0.32 & 0.12 \\
\hline 2072 & 4.58 & 0.03 & 0.11 & 0.02 \\
\hline 2073 & \multicolumn{4}{|c|}{ ( $\alpha$ indeterminate-only surface sample tested) } \\
\hline 2076 & 0.44 & 0.03 & 0.41 & 0.31 \\
\hline 2080 & 0.03 & 0.15 & 0.05 & 3.53 \\
\hline 2082 & 0.95 & 0.04 & 0.91 & 0.44 \\
\hline 2084 & 1.23 & 0.04 & 0.61 & 0.15 \\
\hline 2096 & 0.21 & 0.06 & 0.93 & 7.19 \\
\hline 2097 & $0.6 i$ & 0.05 & 0.28 & 0.09 \\
\hline 2115 & 0.25 & 0.16 & 0.49 & 0.54 \\
\hline 2118 & 0.18 & 0.07 & 0.52 & 0.78 \\
\hline 2119 & 0.17 & 0.06 & 0.35 & 4.03 \\
\hline 2120 & \multicolumn{4}{|c|}{ (a positive-disturbed soils in stream channel) } \\
\hline 2121 & 0.69 & 0.04 & 0.06 & 0.24 \\
\hline
\end{tabular}

${ }^{a}$ LADB - Los Alamos Data Base.

${ }^{b}$ FSD - Fractional Standard Deviation.
TABLE $\mathbf{X}$

\section{SURFACE SOIL CONCENTRATION OF

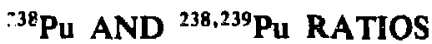

\begin{tabular}{|c|c|c|c|}
\hline Location & $\begin{array}{c}\text { Surface Cone } \\
\text { of }{ }^{238} \mathrm{Pu} \\
(\mathrm{pCi} / \mathrm{g})\end{array}$ & FSD $^{a}$ & ${ }^{238,239} \mathrm{Pu}$ \\
\hline 2009 & 0.023 & 0.17 & 0.05 \\
\hline 2014 & 0.0059 & 0.32 & 0.04 \\
\hline 2016 & 0.004 & 0.50 & 0.03 \\
\hline 2018 & 0.204 & 001 & 0.05 \\
\hline 2047 & 0.045 & 0.11 & 0.05 \\
\hline 2060 & 0.048 & 0.11 & 0.05 \\
\hline 2065 & 0.012 & 0.17 & 0.04 \\
\hline 2072 & 0.224 & 0.004 & 0.05 \\
\hline 2073 & 0.323 & 0.05 & 0.05 \\
\hline 2076 & 0.016 & 0.13 & 0.04 \\
\hline 2082 & 0.046 & 0.11 & 0.05 \\
\hline 2119 & 0.008 & 0.33 & 0.05 \\
\hline 2121 & 0.041 & 0.10 & 0.06 \\
\hline
\end{tabular}

${ }^{8}$ FSD - Fractional Standard Deviation.

outside of $\mathrm{GZ},{ }^{60} \mathrm{Co}$ was detected at 21 locations, whereas ${ }^{152} \mathrm{Eu}$ and ${ }^{155} \mathrm{Eu}$ were detected at only four locations in situ. The average ${ }^{60} \mathrm{Co}$ areal concentration area from ground zero areas was $2.5 \pm 1.5 \mathrm{nCi} / \mathrm{m}^{2}$. The ${ }^{60} \mathrm{Co}$ distribution for the fallout area does not correlate with the ${ }^{137} \mathrm{Cs}$ area concentrations. Away from ground zero areas, the correlation coefficient for ${ }^{60} \mathrm{Co}$ and ${ }^{137} \mathrm{Cs}$ is 0.05 . There was no correlation itween ${ }^{60} \mathrm{Co}$ and ${ }^{90} \mathrm{Sr}$ in soils.

Laboratory counting of the soil samples in tuna cans provided additional information about the fission products from the Trinity fallout at GZ. The following radionuclides: ${ }^{60} \mathrm{Co},{ }^{137} \mathrm{Cs},{ }^{133} \mathrm{Ba},{ }^{152} \mathrm{Eu},{ }^{154} \mathrm{Eu}$, and ${ }^{155} \mathrm{Eu}$ were detected in most soil samples. Table XII indicates the range of soil concentrations of the radionuclides detected. The range is wide but not unusual in view of the disturbances of the Trinity GZ area. The area was plowed and bladed in 1945 to renove materials from the surface. In particular, the fused sand and soi: called Trinitite was being picked up by visitors as a memento of the event. The surface was bladed and the Trinitite was burien in trenches in the GZ area in 1952. Other 
TABLE X]

1977 ESTMMATES OF $1 \mathrm{~km}$ AND TOTAL PLUTONIUM INVENTORY $\left(\mathbf{n C i} / \mathbf{m}^{2}\right)$

\begin{tabular}{|c|c|c|c|c|}
\hline $\begin{array}{l}\text { LADB" } \\
\text { No. }\end{array}$ & $\begin{array}{c}1-\mathrm{cm}{ }^{239} \mathrm{Pu} \\
\text { lnventory }\left(1_{1}\right)\end{array}$ & $\begin{array}{c}\text { FSD }^{b} \\
\left(\mathbf{l}_{T}\right) \\
\end{array}$ & $\begin{array}{l}\text { Total }{ }^{239} \mathrm{Pu}_{\mathrm{U}} \\
\text { Inventory }\left(\mathrm{I}_{1}\right)\end{array}$ & $\begin{array}{c}\text { FSD }^{\mathrm{b}} \\
\left(\mathbf{I}_{\mathrm{T}}\right) \\
\end{array}$ \\
\hline 1995 & $\operatorname{Bik}_{B}(<0.01)$ & $\ldots$ & $\cdots$ & $\cdots$ \\
\hline 1998 & 364.5 & 0.02 & s & -.. \\
\hline 2001 & 973.5 & 0.02 & c & $\ldots$ \\
\hline 2003 & 57.0 & 0.05 & c & $\ldots$ \\
\hline 2009 & 7.2 & 0.04 & c & -.- \\
\hline 2014 & 2.5 & 0.05 & s & --- \\
\hline 2016 & 1.8 & 0.08 & : & $\cdots$ \\
\hline 2018 & 10.1 & 0.04 & $\varepsilon$ & $\ldots$ \\
\hline 2026 & 52.7 & 0.03 & 210.2 & 0.08 \\
\hline $202 ?$ & 25.7 & 0.03 & 131.6 & 0.13 \\
\hline 2028 & 61.1 & 0.04 & 237.4 & 0.07 \\
\hline 2037 & 27.5 & 0.03 & 112.9 & 0.11 \\
\hline 2047 & 14.7 & 0.04 & 114.1 & 0.32 \\
\hline$? 2048$ & 5.9 & 0.05 & $25 . \mathrm{i}$ & 0.66 \\
\hline 2049 & 3.7 & 0.04 & 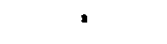 & $\ldots$ \\
\hline 2052 & 1.8 & 0.07 & 11.7 & 0.59 \\
\hline 2057 & 10.5 & 0.03 & 57.1 & 0.09 \\
\hline 2059 & 18.2 & 0.06 & 79.6 & 0.36 \\
\hline 2060 & 15.9 & 0.04 & 123.4 & 0.27 \\
\hline 2065 & 4.1 & 0.04 & a & $\ldots$ \\
\hline 2071 & 23.1 & 0.03 & 129.9 & 0.37 \\
\hline 2072 & 68.7 & 0.03 & 796.3 & 0.18 \\
\hline 2073 & 100.5 & 0.03 & 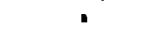 & $\ldots$ \\
\hline 2076 & 6.6 & 0.03 & 32.6 & 0.76 \\
\hline 2082 & 14.3 & 0.04 & 51.3 & 0.49 \\
\hline 2084 & 18.5 & 0.04 & 76.4 & 0.25 \\
\hline 2097 & 9.2 & 0.05 & ' & $\ldots$ \\
\hline 2115 & 3.8 & 0.16 & 17.0 & 1.27 \\
\hline 2118 & 2.7 & 0.07 & 11.9 & 1.55 \\
\hline 2119 & 2.6 & 0.06 & 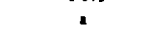 & --- \\
\hline 2120 & 3.5 & 0.13 & $\bullet$ & --- \\
\hline 2121 & 10.4 & 0.04 & $:$ & $\ldots$ \\
\hline
\end{tabular}

LADB - Los Alamos Data Base. bFSD - Fractional Standard Deviation.

Total inventory not calculated because of inadequate data (FSD > 3).

radionuclides identified with low confidence and expected in fallout gamma-ray spectra were ${ }^{144} \mathrm{Ce}$ and ${ }^{125} \mathrm{Sb}$. These latter radionuclides are likely from the Chinese nuclear tests.

In selected scil samples from areas off the White Sands Missile Range, the predominant fission products detected were ${ }^{137} \mathrm{Cs}$ and ${ }^{139} \mathrm{Eu}$. These samples are from a large area including Chupadera Mesa, Gallinas Peak, and the far fallout areas northeast of New Mexico State Highway 14. For laboratory counting, the $0-$ to $5-\mathrm{cm}$ and 10 - to $15-\mathrm{cm}$ samples were selected for counting for in situ
TABLE XII

\section{ACTIVATION AND FISSION PRODUCTS IN BULK SOIL SAMPLES AT TRINITY GZ AREA}

\begin{tabular}{|c|c|c|}
\hline Isatope & $\begin{array}{l}\text { Soil Sample } \\
\text { Interval }(\mathrm{cm})\end{array}$ & $\begin{array}{c}\text { Range of Conc } \\
(\mathrm{pCi} / \mathrm{g})\end{array}$ \\
\hline \multirow[t]{3}{*}{${ }^{60} \mathrm{Co}$} & $0-5$ & $12-60$ \\
\hline & $5-10$ & 12 \\
\hline & $10-15$ & $0.12-18$ \\
\hline \multirow[t]{3}{*}{${ }^{137} \mathrm{Cs}$} & $0-5$ & $4.2-21$ \\
\hline & $5-10$ & $0.52-48$ \\
\hline & $10-15$ & $0.79-16$ \\
\hline \multirow[t]{3}{*}{${ }^{133} \mathbf{B a}$} & $0-5$ & $1.6-3.8$ \\
\hline & $5-10$ & $0.58-2.9$ \\
\hline & $10-15$ & N.D $-1.5^{\mathrm{a}}$ \\
\hline \multirow[t]{6}{*}{${ }^{152} \mathrm{Eu}$} & $0-5$ & $12-1300$ \\
\hline & $5-10$ & $240-270$ \\
\hline & $10-15$ & N.D - 340 \\
\hline & $0-5$ & $16-76$ \\
\hline & $5-10$ & $10-15$ \\
\hline & $10-15$ & N.D -17 \\
\hline
\end{tabular}

Not detected.

detector calibration. Selected 5- to $10-\mathrm{cm}$ samples were courted, but they were fewer in number.

The mean values for the ${ }^{155} \mathrm{Eu}$ activity in soil were 0.17 $\pm 0.12 \mathrm{pCi} / \mathrm{g}$ for the $0-$ to $5-\mathrm{cm}$ depth and $0.14 \pm 0.07$ $\mathrm{pCi} / \mathrm{g}$ for the 10- to $15-\mathrm{cm}$ depth. An analysis of variance indicates the means are equal at the $99 \%$ level of significance. The same samples have unequal means for ${ }^{137} \mathrm{Cs}$ concentration with the greatest amounts in the 0 - to 5 -cm semples. The equal concentrations of ${ }^{155}$ Eu concentrations in the $0-$ to $5-\mathrm{cm}$ and $10-$ to $15-\mathrm{cm}$ soil depths indicate possible movement of Eu deeper into the soil with time. For a deeper soil sample of 20 to $25 \mathrm{~cm}$ in the same region but for only one location, the ${ }^{155} \mathrm{Eu}$ concentration was $0.23 \mathrm{pCi} / \mathrm{g}$.

\section{Natural Radioactivity in Soils}

The in situ $\mathrm{Ge}(\mathrm{Li})$ detector system detects the gammaemitting primordial radionuclides and these radiations can be used for calibration of the detector for energy. The quantities of ${ }^{40} \mathrm{~K}$ are determined directiy. The quantities 
of ${ }^{238} \mathrm{U}$ and ${ }^{232} \mathrm{Th}$ are determined from the quantities of gamma-emitting daughter products. Use of the daughter products assumes radiological equilibrium between the parents and daughters with minimal or unimportant cliemical redistribution in the soils.

The ${ }^{40} \mathrm{~K}$ concentration, listed in Tabie XIII, averaged $17.7 \pm 0.56 \mathrm{pCi} / \mathrm{g}$ for the region surveyed with a range of values from 3.4 to $42 \mathrm{pCi} / \mathrm{g}$. The wide range of values is consistent with the variable geological features of the region surveyed. The NCRP report on natural background radiation in the L.S. summarizes the concentrations of major radionuclides in rock types and soil. ${ }^{23}$ The expected range of values would be predicted to be between $2 \mathrm{pOi} / \mathrm{g}$ for carbonate rocks and $40 \mathrm{pCi} / \mathrm{g}$ for salic rocks. The geological formations of the region are composed of limestones and sandstones with a small area at the top of Gallinas Peak being intrusive rock identified as rhyolite. The highest value, $42 \mathrm{pCi} / \mathrm{g}$, was from a region of volcanic rocks in a canynn area where ${ }^{40} \mathrm{~K}$ content would be expected to exceed $30 \mathrm{pCi} / \mathrm{g}$. Soils for the total U.S. averaged $12 \mathrm{pCi} / \mathrm{g}$ for in situ measurements taken by Lowder et al. in 1964 compared with the average of $18 \mathrm{pCi} / \mathrm{g}$ for this study. ${ }^{24}$

The concentrations of the natural radionuclides ${ }^{232} \mathrm{Th}$ and ${ }^{238} \mathrm{U}$ also varied within the study region. The ${ }^{232} \mathrm{Th}$ average concentration for all in situ locations was $0.94 \pm$ $0.04 \mathrm{pCi} / \mathrm{g}$ with a range from $0.12 \mathrm{pCi} / \mathrm{g}$ to $2.8 \mathrm{pCi} / \mathrm{g}$. The ${ }^{238} \mathrm{U}$ concentrations for in situ locations averaged $0.90 \pm 0.03 \mathrm{pCi} / \mathrm{g}$ with a range from $0.32 \mathrm{pCi} / \mathrm{g}$ to 2.0 $\mathrm{pCi} / \mathrm{g}$. The highest values of ${ }^{232} \mathrm{Th}$ were detected at the top of Gallinas Peak where intrusive rocks occur. The highest uranium value was detected in an area that integrates water runoff in a basin area. Areas of exposed limestone where soils were relatively thin contained the

\section{TABLE XIII}

\section{SOIL CONCENTRATIONS OF NATURALLY OCCURRING GAMMA-EMITTERS}

\begin{tabular}{|c|c|c|c|}
\hline Radionuclide & $\mathrm{n}$ & $\begin{array}{l}\text { Mean Conc. } \\
(\mathrm{pCi} / \mathrm{g}) \pm \text { S.E. }\end{array}$ & $\begin{array}{l}\text { Range } \\
(\mathrm{pCi} / \mathrm{g})\end{array}$ \\
\hline${ }^{40} \mathrm{~K}$ & 101 & $17.7 \pm 0.56$ & $3.4-42$ \\
\hline${ }^{232} \mathrm{Th}$ & 101 & $0.94 \pm 0.04$ & $0.14-2.8$ \\
\hline${ }^{238} \mathrm{U}$ & 101 & $0.93 \pm 0.03$ & $0.32-2.0$ \\
\hline
\end{tabular}

lowest concentrations of ${ }^{232} \mathrm{Th}$ and ${ }^{238} \mathrm{U}$, as expected from literature values. ${ }^{23,24}$

\section{DATA SUMMARY FOR SOILS}

The separation of the overall data base into smaller locations of measurement of radionuclides generally followed topographic areas of the fallout area from the Trinity test. An artificiality of the boundary selection was the use of roads or a property boundary, which tends to result in a mixture of topographic features. However, directions and distances from GZ and land use all contributed to the choice of boundaries for separate data treatment.

The areas are bounded in Fig. 7 by solid lines. Trinity GZ is illustrated in Figs. 4 and 11. Located within a special fenced area on the White Sands Missile Range, Trinity GZ is the area of ground disturbance left from the initial test. Figure 9 indicates the sampling locations for the White Sands Missile Range, Bingham area, and Chupadera Mesa. Earlier surveys by Larson et al. and special studies by Hakonson et al. indicated localized areas of higher fallout on Chupadera Mesa. ${ }^{6,9}$ Figure 7 includes the sample locations for the far fallout area. Figure 10 indicates the location of samples in the San Antonio area, which is west and out of the fallout path.

The soil data for each area are summarized in Tables XIV through XIX. The results listed in the tables are summaries of statistical treatment of the data by area to determine means and standard errors (standard deviation of the mean). ${ }^{25}$ The dates associated with the ${ }^{239,249} \mathrm{Pu}$ determinations are the data from studies by Olafson and Larson in 1948 and 1950, Los Alamos in 1972, EPA in 1973 and 1974, and Los Alamos in 1977 and 1983. Also noted is the depth of soil samples taken br use the sampling schemes used by different investigators varied.

\section{A. Plutonium in Soils}

From Appendix D, the level of ${ }^{239-241} \mathrm{Pu}$ in soils from worldwide fallout deposited in northern New Mexico is $0.008 \pm 0.01 \mathrm{pCi} / \mathrm{g}$. Of the areas listed in Tables XIV through XIX, only the San Antonio Area contains ${ }^{239-240} \mathrm{Pu}$ in soils at concentrations as low as Northern New Mexico fallout levels. The other areas of the fallout zone all contain ${ }^{239-240} \mathrm{Pu}$ above worldwide fallout levels.

The no action level proposed by the DOE Remedial Action Programs for ${ }^{239,240} \mathrm{Pu}$ is $100 \mathrm{pCi} / \mathrm{g}$. The only 


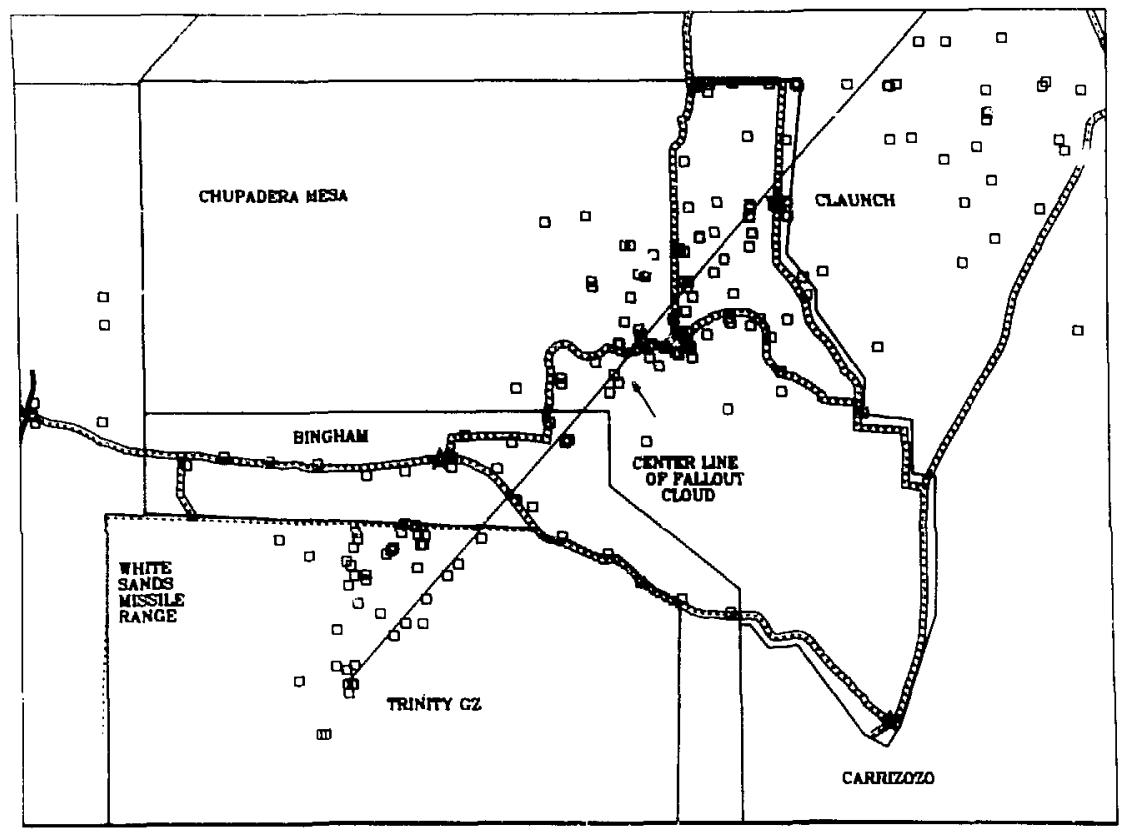

Fig. 9. White Sands Missile Range, Bingham, and Chupadera Mesa sample iocations.

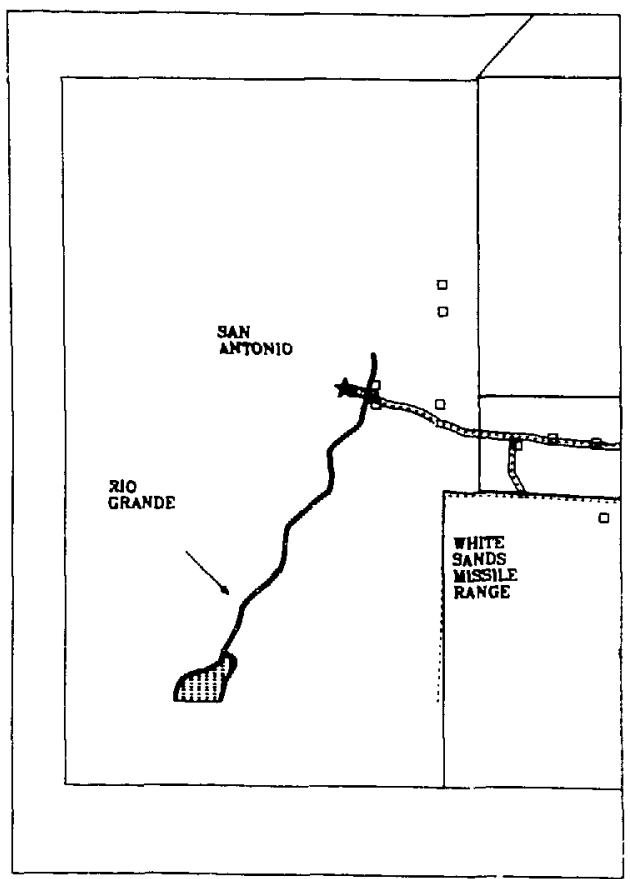

Fig. 10. Sample locations for the San Antonio area. area exceeding this level of plutonium is the controlled inner fenced area of GZ. The EPA has proposed a screening level for no action of $200 \mathrm{nCi} / \mathrm{m}^{2}$, which is equivalent to about $15 \mathrm{pCi} / \mathrm{g}$ in the top $1-\mathrm{cm}$ layer of soil. Measurements of ${ }^{239-240} \mathrm{Pu}$ in controlled areas of GZ exceed this proposed limit. Measurements made in 1972 within $1 \mathrm{~km}$ of $\mathrm{GZ}$ in the fallout path exceed this limit, but EPA measurements in 1973 and Los Alamos measurements in 1972 do not exceed the limits.

\section{B. Cesium-137 in Soils}

The amounts of ${ }^{137} \mathrm{Cs}$ in soils of the $\mathrm{GZ}$ area exceed the levels found in soils elsewhere in the U.S. ${ }^{26,27}$ However, the amounts detected by in situ measurements on the White Sands Missile Range and other fallout areas are within the range of values reported for the areal distributions of worldwide fallout. Table XX lists a range of 19 to $305 \mathrm{nCi} / \mathrm{m}^{2}$ from California to Connecticut. If the measurements at San Antonio are assumed to be levels representing worldwide fallout, the White Sands 
TABLE XIV

\section{GROUND ZERO SURFACE MEASUREMENTS}

\begin{tabular}{|c|c|c|c|c|}
\hline Radionuslide & $\mathbf{N}$ & Mean \pm S.E. ${ }^{\mathrm{a}}$ & Min & Max \\
\hline${ }^{60} \mathrm{Co}$ & 6 & $5554 \pm 3094 \mathrm{nCi} / \mathrm{m}^{2}$ & 0 & 19300 \\
\hline${ }^{137} \mathrm{Cs}$ & 6 & $8104 \pm 3772 \mathrm{nCi} / \mathrm{m}^{2}$ & 488 & 23000 \\
\hline${ }^{152} \mathrm{Eu}$ & 6 & $107200 \pm 54400 \mathrm{nCi} / \mathrm{m}^{2}$ & 842 & 340000 \\
\hline Natural gamma & 6 & $7.9 \pm 0.7 \mu \mathrm{R} / \mathrm{h}$ & 5.5 & 10.0 \\
\hline Total gamma & 6 & $131 \pm 62 \mu \mathrm{R} / \mathrm{h}$ & 9.8 & 397 \\
\hline${ }^{40} \mathrm{~K}$ & 6 & $24 \pm 4.4 \mathrm{pCi} / \mathrm{g}$ & 12 & 43 \\
\hline${ }^{232} \mathrm{Th}$ & 6 & $0.86 \pm 0.03 \mathrm{pCi} / \mathrm{g}$ & 0.78 & 0.97 \\
\hline${ }^{238} \mathrm{U}$ & 6 & $0.60 \pm 0.13 \mathrm{pCi} / \mathrm{g}$ & 0 & 0.88 \\
\hline${ }^{2.19}, 240 \mathrm{Pu}$ & & & $b$ & \\
\hline Inner fence, $0-1 \mathrm{~cm}$ & 1 & (1983) $22.8 \pm 0.2 \mathrm{pCi} / \mathrm{g}$ & b & b \\
\hline $1-6 \mathrm{~cm}$ & 1 & (1983) $156 \pm 15 \mathrm{pCi} / \mathrm{g}$ & $\mathrm{b}$ & b \\
\hline $0-15 \mathrm{~cm}$ & 1 & (1983) $23.7 \pm 0.4 \mathrm{pCi} / \mathrm{g}$ & $\mathrm{b}$ & b \\
\hline $15-30 \mathrm{~cm}$ & 1 & (1983) $256 \pm 3 \mathrm{pCi} / \mathrm{g}$ & $\mathrm{b}$ & b \\
\hline $30-45 \mathrm{~cm}$ & 1 & (1983) $0.4 \pm 0.02 \mathrm{pCi} / \mathrm{g}$ & $\mathrm{b}$ & b \\
\hline Retween fences, $0-1 \mathrm{~cm}$ & 11 & (1983) $5.8 \pm 9.5 \mathrm{pCi} / \mathrm{g}$ & 0.04 & 28 \\
\hline $1-6 \mathrm{~cm}$ & 9 & (1983) $1.14 \pm 2.9 \mathrm{pCi} / \mathrm{g}$ & 0.02 & 8.8 \\
\hline $15-30 \mathrm{~cm}$ & 11 & (1983) $0.0053 \pm 0.003 \mathrm{pCi} / \mathrm{g}$ & 0.002 & 0.01 \\
\hline Inner fence, $0-2.5 \mathrm{~cm}$ & 2 & (1972) $127 \pm 180 \mathrm{pCi} / \mathrm{g}$ & 0.04 & 255 \\
\hline Combined, $0-5 \mathrm{~cm}$ & 3 & $(1977) 31 \pm 31 \mathrm{pCi} / \mathrm{g}$ & 3.8 & 64.8 \\
\hline $5-10 \mathrm{~cm}$ & 3 & (1977) $34 \pm 30 \mathrm{pCi} / \mathrm{g}$ & 0.05 & 57 \\
\hline $10-15 \mathrm{~cm}$ & 3 & $(197767 \pm 116 \mathrm{pCi} / \mathrm{g}$ & $<$ MDA & 201 \\
\hline \multicolumn{5}{|l|}{${ }^{137} \mathrm{Cs}$} \\
\hline Inner fence, $0-1 \mathrm{crn}$ & 1 & $16.5 \pm 3.3 \mathrm{pCi} / \mathrm{g}$ & b & $\mathrm{b}$ \\
\hline $1-6 \mathrm{~cm}$ & 1 & $21.8 \pm 4.4 \mathrm{pCi} / \mathrm{g}$ & b & $\mathrm{b}$ \\
\hline $0-15 \mathrm{~cm}$ & 1 & $12.6 \pm 2.5 \mathrm{pCi} / \mathrm{g}$ & b & $\mathrm{b}$ \\
\hline $15-30 \mathrm{~cm}$ & 1 & $21.5 \pm 4.3 \mathrm{pCi} / \mathrm{g}$ & b & $\mathrm{b}$ \\
\hline $30-45 \mathrm{~cm}$ & 1 & $0.67 \pm 0.19 \mathrm{pCi} / \mathrm{g}$ & b & $b$ \\
\hline Between fences, $\mathrm{C}-1 \mathrm{~cm}$ & 3 & $0.54 \pm 0.37 \mathrm{pCi} / \mathrm{g}$ & 0.17 & 0.92 \\
\hline $1-6 \mathrm{~cm}$ & 3 & $0.64 \pm 0.48 \mathrm{pCi} / \mathrm{g}$ & 0.29 & 1.19 \\
\hline $4-10 \mathrm{~cm}$ & 3 & $0.33 \pm 0.12 \mathrm{pCi} / \mathrm{g}$ & 0.22 & 0.32 \\
\hline $10-15 \mathrm{~cm}$ & 3 & $0.07 \pm 0.41$ & -0.33 & 0.49 \\
\hline
\end{tabular}


TABLE XIV (cont)

\begin{tabular}{|c|c|c|c|c|}
\hline Radionuclide & $\mathbf{N}$ & Mean \pm S.E. ${ }^{a}$ & Min & Max \\
\hline \multicolumn{5}{|l|}{${ }^{152} \mathrm{Eu}$} \\
\hline Inner fence, $0-1 \mathrm{~cm}$ & 1 & $284 \pm 29 \mathrm{pCi} / \mathrm{g}$ & $\mathrm{b}$ & $b$ \\
\hline $1-6 \mathrm{~cm}$ & 1 & $245 \pm 25 \mathrm{pCi} / \mathrm{g}$ & b & $\mathrm{b}$ \\
\hline $0-15 \mathrm{~cm}$ & 2 & $382 \pm 167 \mathrm{pCi} / \mathrm{g}$ & 264 & 501 \\
\hline $15-30 \mathrm{~cm}$ & 2 & $1013 \pm 79 \mathrm{pCi} / \mathrm{g}$ & 957 & 1069 \\
\hline $30-45 \mathrm{~cm}$ & 2 & $225 \pm 80 \mathrm{pCi} / \mathrm{g}$ & 169 & 282 \\
\hline $76-91 \mathrm{~cm}$ & 2 & $12 \pm 16 \mathrm{pCi} / \mathrm{g}$ & 0.5 & 24 \\
\hline $106-122 \mathrm{~cm}$ & 2 & $2.2 \pm 2.4 \mathrm{pCi} / \mathrm{g}$ & 0.4 & 3.9 \\
\hline Between fences, $0-1 \mathrm{~cm}$ & 8 & $20 \pm 18 \mathrm{pCi} / \mathrm{g}$ & 3.4 & 59 \\
\hline $1-6 \mathrm{~cm}$ & 8 & $18 \pm 14 \mathrm{pCi} / \mathrm{g}$ & 3.5 & 46 \\
\hline
\end{tabular}

Missile Range. Chupadera Mesa, and Far Fallout Zone are $2.4,4.2$, and 2.2 times higher than levels expected in central New Mexico.

Cesium also can be used as an indicator of the slow changes in fallout distribution with time. Measurements by the in situ detector on Chupadera Mesa were made for different land forms at several locations. The Chupadera Mesa area has several closed drainage collection points where the water and associated sediments from rainfall runoff collect. Measurements were made on the slopes above a collection point and on the sediment bed in the dry collection areas. Table XXI summarizes the data taken for such drainage systems on Chupadera Mesa. The arithmetic mean values for ${ }^{137} \mathrm{Cs}$ on slopes above drainages and their associated collection points are not equal with a $99.5 \%$ confidence using Student's t-test for equal means. The data suggest that after 32 years the cesium bound to soils is slowly being transported into water and sediment collection points. However, the process appears to be slow and any increased areal concentration in the collection sediment points will be offset by radioactive decay with half of the activity disappearing every 30.2 years.

\section{Strontium-90 in Soils}

Measurements of ${ }^{90} \mathrm{Sr}$ in soils during the 1977 survey were restricted to relatively few samples because of analytical costs. From the limited data, comparisons of the ${ }^{90} \mathrm{Sr}$ in soils of Chupadera Mesa and the Far Fallout Zone with measurements of worldwide fallout in soils at various locations in the U.S. indicate a clear influence from the Trinity test. Table XXII summarizes data for locations in mountain states of the U.S.; ${ }^{90} \mathrm{Sr}$ levels in the fallout zone from the Trinity test range from 10 to 40 times those both north and south of central New Mexico.

\section{AIRBORNE RADIOACTIVE MATERIAL3}

Airborne radioactive materials measurements at Trinity site and in the fallout zone are extremely limited. During the 1973 and 1974 survey by the EPA, a 10month air sampling was conducted on Chlipadera Mesa and at Socorro, New Mexico, a community out of the influence of the Trinity test. ${ }^{13}$ Air concentrations of plutonium at both locations were equal, but isotopic ratios at Chupadera Mesa indicated the Trinity test plutonium contributed the major activity while worldwice fallout contributed the major activity at Socorro. ${ }^{13}$

Table XXIII includes plutonium concentrations in air samples taken at $\mathrm{GZ}$ and at a control site $5.2 \mathrm{~km}$ south of $\mathrm{GZ}$ in 1983. Alsc included are the air concentrations calculate $\iota^{\prime}$ for resuspended plutonium (see Appendix D for details).

Comparison of the calculated resuspended plutonium on Chupadera Mesa with the measured values indicates the calculations overestimate the actual amount by a 
TABLE XV

WHITE SAINDS MISSILE RANGE FALLOUT ZONE SC:i MEASUREMENTS

\begin{tabular}{|c|c|c|c|c|c|}
\hline Radionuclide & $\mathbf{N}$ & $\begin{array}{l}\text { Depth } \\
\text { (cm) }\end{array}$ & Mean \pm S.E. ${ }^{\mathrm{a}}$ & Min & $\operatorname{Max}$ \\
\hline${ }^{7} \mathrm{Be}$ & 22 & $\cdots$ & $5.7 \pm 1.2 \mathrm{nCi} / \mathrm{m}^{2}$ & $<\mathrm{MDA}$ & 19 \\
\hline${ }^{60} \mathrm{Co}$ & 22 & --- & $27 \pm 23 \mathrm{nCi} / \mathrm{m}^{2}$ & $<\mathrm{MDA}$ & 503 \\
\hline${ }^{137} \mathrm{Cs}$ & 22 & -- & $162 \pm 42 \mathrm{nCi} / \mathrm{m}^{2}$ & 2.1 & 858 \\
\hline${ }^{152} \mathrm{Eu}$ & 22 & --- & $77 \pm 77 \mathrm{nCi} / \mathrm{m}$ & $<\mathrm{MDA}$ & 1696 \\
\hline${ }^{155} \mathrm{Eu}$ & 22 & -- & $5.5 \pm 4.0 \mathrm{nCi} / \mathrm{m}^{2}$ & $<$ MDA & 82 \\
\hline${ }^{95} \mathrm{Nb}$ & 22 & --- & $3.1 \pm 0.26 \mathrm{nCi} / \mathrm{m}^{2}$ & $<\mathrm{MDA}$ & 4.6 \\
\hline${ }^{95} \mathrm{Zr}$ & 22 & --- & $2.5 \pm 0.27 \mathrm{nCi} / \mathrm{m}^{2}$ & $<\mathrm{MDA}$ & 5 \\
\hline${ }^{103} \mathrm{Ru}$ & 22 & $\cdots$ & $0.14 \pm 0.08 \mathrm{nCi} / \mathrm{m}^{2}$ & $<$ MDA & 1.5 \\
\hline Natural gamma & 23 & -- & $7.8 \pm 0.65 \mu \mathrm{R} / \mathrm{h}$ & 1.5 & 16 \\
\hline Total Gamma & 23 & $--\cdot$ & $7.9 \pm 0.56 \mu \mathrm{R} / \mathrm{h}$ & 1.8 & 12 \\
\hline${ }^{40} \mathrm{~K}$ & 22 & -- & $19 \pm 1.4 \mathrm{pCi} / \mathrm{g}$ & 4.4 & 31 \\
\hline${ }^{238} U$ & --- & --- & $0.88 \pm 0.05 \mathrm{pCi} / \mathrm{g}$ & 0.48 & 1.4 \\
\hline${ }^{232} \mathrm{Th}$ & 22 & $\cdots$ & $0.94 \pm 0.08 \mathrm{pci} / \mathrm{g}$ & 0.29 & 1.8 \\
\hline \multirow[t]{3}{*}{${ }^{238} \mathrm{Pu}$} & 7 & $0-5$ & $0.55 \pm 0.43 \mathrm{pCi} / \mathrm{g}$ & $<\mathrm{MDA}$ & 3 \\
\hline & $--\cdot$ & $5-10$ & $0.38 \pm 0.38 \mathrm{pCi} / \mathrm{g}$ & $<\mathrm{MDA}$ & 2.3 \\
\hline & -- & $10-15$ & $0.009 \pm 0.0 n 5 \mathrm{pCi} / \mathrm{g}$ & $<\mathrm{MDA}$ & 0.03 \\
\hline${ }^{239} \mathrm{Pu}(1948)$ & 4 & $0-2.5$ & $1.32 \pm 0.50 \mathrm{pCi} / \mathrm{g}$ & 0.10 & 2.5 \\
\hline${ }^{239} \mathrm{Pu}(1972)$ & 4 & $0-2.5$ & $63 \pm 63 \mathrm{pCi} / \mathrm{g}$ & 0.04 & 255 \\
\hline (1972) & 4 & $2.2-10$ & $65 \pm 65 \mathrm{pCi} / \mathrm{g}$ & $<\mathrm{MDA}$ & 263 \\
\hline$(1972)$ & 4 & $10-30$ & $15 \pm 15 \mathrm{pCi} / \mathrm{g}$ & $<\mathrm{MDA}$ & 62 \\
\hline (1973) & 13 & $0-5$ & $\begin{array}{l}99 \pm 84 \mathrm{nCi} / \mathrm{m}^{2} \\
(1.42 \mathrm{pCi} / \mathrm{g})\end{array}$ & 0.3 & 1100 \\
\hline (1977) & 7 & $0-5$ & $10 \pm 9 \mathrm{pCi} / \mathrm{g}$ & $<\mathrm{MDA}$ & 65 \\
\hline (1977) & 6 & $5-10$ & $7.6 \pm 7.3 \mathrm{pCi} / \mathrm{g}$ & $<\mathrm{MDA}$ & 44 \\
\hline$(1977)$ & 7 & $10-15$ & $29 \pm 29 \mathrm{pCi} / \mathrm{g}$ & $<$ MDA & 201 \\
\hline \multirow[t]{3}{*}{${ }^{90} \mathrm{Sr}$} & 4 & $0-5$ & $1.8 \pm 1.4 \mathrm{pCi} / \mathrm{g}$ & 0.3 & 6 \\
\hline & 4 & $5-10$ & $0.38 \pm 0.08 \mathrm{pCi} / \mathrm{g}$ & 0.2 & 0.6 \\
\hline & 3 & $10-15$ & $0.70 \pm 0.46 \mathrm{pCi} / \mathrm{g}$ & 0.1 & 1.6 \\
\hline \multirow[t]{3}{*}{${ }^{137} \mathrm{Cs}$} & 12 & $0-5$ & $4.5 \pm 2.3 \mathrm{pCi} / \mathrm{g}$ & 0.22 & 27 \\
\hline & 12 & $5-10$ & $4.9 \pm 2.6 \mathrm{pCi} / \mathrm{g}$ & $<\mathrm{MDA}$ & 25 \\
\hline & 10 & $10-15$ & $0.8 \pm 0.7 \mathrm{pCi} / \mathrm{g}$ & $<\mathrm{MDA}$ & 6.3 \\
\hline
\end{tabular}

${ }^{a}$ S.E. - Standard Error. 
TABLE XVI

\section{BINGHAM AREA SOIL MEASUREMENTS, US HIGHWAY 380 CORRIDOR}

\begin{tabular}{|c|c|c|c|c|c|}
\hline Radionuclide & $\mathbf{N}$ & $\begin{array}{l}\text { Depth } \\
\text { (cm) }\end{array}$ & Mean \pm S.E. $^{a}$ & Min & $\operatorname{Max}$ \\
\hline${ }^{7} \mathrm{Be}$ & 2 & --- & $5.8 \pm 5.8 \mathrm{nCi} / \mathrm{m}^{2}$ & $<\mathrm{MDA}^{\mathrm{b}}$ & 12 \\
\hline${ }^{60} \mathrm{Co}$ & 2 & --- & $0.6 \pm 0.6 \mathrm{nCi} / \mathrm{m}^{2}$ & $<$ MDA & 1.2 \\
\hline${ }^{137} \mathrm{Cs}$ & 2 & -- & $52 \pm 28 \mathrm{nCi} / \mathrm{m}^{2}$ & 34 & 69 \\
\hline${ }^{45} \mathrm{Nb}$ & 2 & --- & $11.4 \pm 0.19 \mathrm{nCi} / \mathrm{m}^{2}$ & 1.2 & 1.6 \\
\hline Natural gamma & 2 & --- & $5.6 \pm 0.2 \mu \mathrm{R} / \mathrm{h}$ & 5.4 & 5.7 \\
\hline Total gamma & 2 & --- & $5.8 \pm 0.1 \mu \mathrm{R} / \mathrm{h}$ & 5.7 & 5.9 \\
\hline${ }^{40} \mathrm{~K}$ & 2 & -.. & $12 \pm 0.22 \mathrm{pCi} / \mathrm{g}$ & 12.1 & 12.6 \\
\hline${ }^{232} \mathrm{Th}$ & 2 & --- & $0.68 \pm 0.035 \mathrm{pCi} / \mathrm{g}$ & 0.64 & 0.71 \\
\hline${ }^{218} \mathrm{U}$ & 2 & --- & $0.80 \pm 0.05 \mathrm{pCi} / \mathrm{g}$ & 0.75 & 0.85 \\
\hline${ }^{239,240} \mathrm{Pu}(1948)$ & 2 & $0 \cdot 1.5$ & $0.9 \pm 0.4 \mathrm{pCi} / \mathrm{g}$ & 0.5 & 1.3 \\
\hline$(1972)$ & 2 & $0 .-2.5$ & $0.21 \pm 0.08 \mathrm{pCi} / \mathrm{g}$ & 0.13 & 0.29 \\
\hline$(1972)$ & $\cdots$ & $2.5-10$ & $0.43 \pm 0.32 \mathrm{pCi} / \mathrm{g}$ & 0.12 & 0.75 \\
\hline (i972) & -- & $10-30$ & $0.085 \pm 0.085 \mathrm{pCi} / \mathrm{g}$ & $<\mathrm{MDA}$ & 0.17 \\
\hline$(1973)$ & 14 & $0-5$ & $\begin{array}{r}5.0 \pm 3.3 \mathrm{nCi} / \mathrm{m}^{2} / \\
(0.070 \mathrm{pCi} / \mathrm{g})^{\mathrm{c}}\end{array}$ & 0.56 & 48 \\
\hline
\end{tabular}

${ }^{\mathrm{a}}$ S.E. - Standard Error.

${ }^{\mathrm{b}} \angle \mathrm{MDA}=$ less than minimum detectable activity.

Calculation of the $\mathrm{p} C \mathrm{i} / \mathrm{g}$ based on $0.0143(\mathrm{pCi} / \mathrm{g}) /\left(\mathrm{nCi} / \mathrm{m}^{2}\right)$.

factor of 3. The calculated resuspended plutonium at $\mathrm{GZ}$ overestimates the measured amount by a factor of 2 .

Also included in Table XXIII are comparisons with both DOE and EPA air concentration limits for plutonium. The DOE air concentration limit for insoluble plutonium for an uncontrolled area is $1 \times 10^{6} \mathrm{aCi} / \mathrm{m}^{3}(1 \times$ $\left.10^{-12} \mu \mathrm{Ci} / \mathrm{m} \ell\right){ }^{28}$ The EPA has proposed an air concentration screening limit for no action of $1000 \mathrm{aCi} / \mathrm{m}^{3}$ of transuranics from resuspension sources. ${ }^{29}$ All measured and calculated air concentrations are well below either limit.

\section{EXTERNAL PENETRATING RADIATION}

Two types of externai radiation dose measurements were made for this study. The first was use of the in situ gamma-ray spectroscope to estimate the dose from specific radionuclides. The natural background gamma-ray spectra were summed for the uranium and thorium daughters and ${ }^{10} \mathrm{~K}$. Total external doses were calculated from the gamma-ray spectra. The dose contributions by fission and activation products such as ${ }^{137} \mathrm{Cs}$ and ${ }^{152} \mathrm{Eu}$ were estimated from their spectra. These estimates are listed in Table XXIV.

The second set of measurements was made with thermoluminescent dosimeters (TLDs) at locations on the inner and outer fences of GZ. A measurement was also made at the point of highest instrumental gamma-ray dose near the center of GZ. The locations and results of these measurements are presented in Fig. 11.

From the two sets of measurements, an estimate of the average external dose rate from the Trinity test was made for each area of the fallout zone. Table XXV lists the total measured external dose rate and the dose rate from fission and activation products. These values were used in Appendix D and Chapter 5 for estimates of the doses and the estimates of risk in the Summary, Chapter 1. 
TABLE XVII

CHUPADERA MESA SURFACE SOIL MEASUREMENTS

\begin{tabular}{|c|c|c|c|c|c|}
\hline Radionuclide & $\mathbf{N}$ & $\begin{array}{l}\text { Depth } \\
\text { (cm) }\end{array}$ & Mean \pm S.E. & Min & Max \\
\hline${ }^{\top} \mathrm{Be}$ & 49 & $\cdots$ & $8.8 \pm 1.1 \mathrm{nCi} / \mathrm{m}^{2}$ & $<\mathrm{MDA}^{n}$ & 26 \\
\hline${ }^{\circ 0} \mathrm{Co}$ & 49 & $\cdots$ & $0.58 \pm 0.16 \mathrm{nCi} / \mathrm{m}^{2}$ & $<\mathrm{MDA}$ & 4.2 \\
\hline${ }^{13} \mathrm{Cs}$ & 49 & -- & $280 \pm 30 \mathrm{nCi} / \mathrm{m}^{2}$ & 30 & 947 \\
\hline${ }^{193} \mathrm{Ev}^{6}$ & 49 & $\cdots$ & $0.48 \pm 0.48 \mathrm{nCi} / \mathrm{m}^{2}$ & $\angle M D A$ & 24 \\
\hline${ }^{135} \mathrm{Eu}_{\mathrm{u}}$ & 49 & $\ldots$ & $4.2 \pm 2.4 \mathrm{nCv} / \mathrm{m}^{2}$ & $<M D A$ & 86 \\
\hline${ }^{99} \mathrm{Nb}$ & 49 & $\cdots$ & $4.65 \pm 0.15 \mathrm{nCi} / \mathrm{m}^{2}$ & $<M D A$ & 6.6 \\
\hline${ }^{9} \mathrm{Zr}$ & 49 & $\cdots$ & $2.55 \pm 0.15 \mathrm{nCi} / \mathrm{m}^{2}$ & $\angle M D A$ & 4.2 \\
\hline${ }^{109} \mathrm{Ru}$ & 49 & $\cdots$ & $0.28 \pm 0.07 \mathrm{nCi} / \mathrm{m}^{2}$ & $\angle M D A$ & 1.9 \\
\hline Natura' gamma & 49 & $\cdots$ & $6.7 \pm 0.24 \mu \mathrm{R} / \mathrm{h}$ & 3.5 & 10 \\
\hline Total gam!na & 49 & $\cdots$ & $8.2 \pm 0.32 \mu \mathrm{R} / \mathrm{h}$ & 4.1 & 13 \\
\hline${ }^{10} \mathrm{~K}$ & 49 & $\cdots$ & $16 \pm 0.58 \mathrm{pCi} / \mathrm{g}$ & 6.4 & 24 \\
\hline${ }^{2 "} \mathrm{Th}$ & 49 & $\therefore$ & $0.85 \pm 0.04 \mathrm{pCi}^{\mathrm{g}}$ & 0.36 & 1.42 \\
\hline${ }^{2.28} \mathrm{U}$ & 49 & $\cdots$ & $0.88 \pm 0.04 \mathrm{pCi} / \mathrm{g}$ & 0.34 & 1.81 \\
\hline \multirow[t]{4}{*}{${ }^{2.18} \mathrm{Pu}$} & 19 & 0.5 & $0.083 \pm 0.020 \mathrm{pCi} / \mathrm{g}$ & $\angle M D A$ & 0.32 \\
\hline & 15 & $5 \cdot 10$ & $0.023 \pm 0.013 \mathrm{pCi} / \mathrm{g}$ & $\angle M D A$ & 0.19 \\
\hline & 15 & $10 \cdot 15$ & $0.006 \pm 0.004 \mathrm{pCi} / \mathrm{g}$ & $\angle M D A$ & 0.06 \\
\hline & 3 & $15 \cdot 20$ & $0.003 \pm 0.003 \mathrm{pCi} / \mathrm{g}$ & $\angle M D A$ & 0.01 \\
\hline${ }^{239.240} \mathrm{Pu}(1948)$ & 10 & 0.2 .5 & $3.1 \pm 1.3 \mathrm{pCi} / \mathrm{g}$ & $\angle M D A$ & 10.8 \\
\hline$(1950)$ & 9 & $0 \cdot 2.5$ & $3.2 \pm 1.2 \mathrm{pCi} / \mathrm{g}$ & 0.2 & 11 \\
\hline (1972) & 3 & $0 \cdot 2.5$ & $0.80 \pm 0.34 \mathrm{pCi} / \mathrm{g}$ & $<\mathrm{MDA}$ & 1.4 \\
\hline$(1972)$ & 3 & $2.5-10$ & $0.15 \pm 0.10 \mathrm{pCi} / \mathrm{g}$ & 0.02 & 0.34 \\
\hline$(1972)$ & $\ldots$ & $10 \cdot 30$ & $0.033 \pm 0.015 \mathrm{pCi} / \mathrm{g}$ & 0.01 & 0.06 \\
\hline (1973) & .. & 0.5 & $20.6 \pm 4.3 \mathrm{nCi} / \mathrm{m}^{2}$ & 0.4 & 86 \\
\hline & & & $(0.29 \mathrm{pCi} / \mathrm{g})^{\mathrm{d}}$ & & \\
\hline$(1977)$ & 19 & $0-5$ & $1.7 \pm 0.41 \mathrm{pCi} / \mathrm{g}$ & 0.03 & 6.7 \\
\hline$(1977)$ & 14 & $5-10$ & $0.38 \pm 0.27 \mathrm{pCi} / \mathrm{g}$ & $\angle M D A$ & 3.9 \\
\hline$(1977)$ & 16 & $10 \cdot 15$ & $0.11 \pm 0.07 \mathrm{pCi} / \mathrm{g}$ & $\angle \mathrm{MDA}$ & 1.2 \\
\hline (1977) & 3 & 1520 & $0.033 \pm 0.03 \mathrm{pCi} / \mathrm{g}$ & $\angle \mathrm{MDA}$ & 0.09 \\
\hline \multirow[t]{2}{*}{${ }^{90} \mathrm{Sr}$} & 7 & $0-5$ & $2.3 \pm 1.0 \mathrm{pCi} / \mathrm{g}$ & 0.20 & 6.8 \\
\hline & 3 & $10-15$ & $0.76 \pm 0.47 \mathrm{pCi} / \mathrm{g}$ & 0.22 & 1.7 \\
\hline \multirow[t]{4}{*}{${ }^{1 "} \mathrm{Cs}$} & 27 & 0.5 & $2.81 \pm 0.52 \mathrm{pCi} / \mathrm{g}$ & $\angle M D A$ & 10.4 \\
\hline & 4 & $5 \cdot 10$ & $0.16 \pm 0.02 \mathrm{pCi} / \mathrm{g}$ & 0.12 & 0.22 \\
\hline & 16 & $10 \cdot 15$ & $0.04 \pm 0.02 \mathrm{pCi} / \mathrm{g}$ & $<\mathrm{MDA}$ & 0.21 \\
\hline & 1 & $20 \cdot 25$ & 0.05 & -.. & $\ldots$ \\
\hline
\end{tabular}

'S.E. - Standard Error.

${ }^{b} \angle \mathrm{MDA}=$ less than minimum detectphle activity.

'Forty-eight observations for ${ }^{132} \mathrm{Eu}$ 4. ie below MDA.

${ }^{d} \mathrm{Calculation}$ of the $\mathrm{pCi} / \mathrm{g}$ based on $0.0143(\mathrm{pCi} / \mathrm{g}) /\left(\mathrm{nCi} / \mathrm{m}^{2}\right)$. 
TABLE XVIII

FAR FALLOUT ZONE SURFACE SOIL MEASUREMENTS

\begin{tabular}{|c|c|c|c|c|c|}
\hline Radionuclide & $\mathbf{N}$ & $\begin{array}{l}\text { Depth } \\
\text { (cm) }\end{array}$ & Mean \pm S.E." & Min & Max \\
\hline${ }^{\prime} \mathrm{Be}$ & 27 & $\cdots$ & $12 \pm 1.2 \mathrm{nCi} / \mathrm{m}^{2}$ & $<\mathrm{MDA}^{\mathrm{b}}$ & 21 \\
\hline${ }^{60} \mathrm{Co}$ & 27 & $\cdots$ & $0.82 \pm 0.61 \mathrm{nCi} / \mathrm{m}^{2}$ & $<\mathrm{MDA}$ & 16 \\
\hline${ }^{137} \mathrm{Cs}$ & 27 & $\cdots$ & $152 \pm 34 \mathrm{nCi} / \mathrm{m}^{2}$ & 10 & 765 \\
\hline${ }^{99} \mathrm{Nb}$ & 27 & --- & $4.5 \pm 0.29 \mathrm{nCi} / \mathrm{m}^{2}$ & $<\mathrm{MDA}$ & 6.4 \\
\hline${ }^{95} \mathrm{Zr}$ & 27 & $\cdots$ & $2.9 \pm 0.24 \mathrm{nCi} / \mathrm{m}^{2}$ & $<\mathrm{MDA}$ & 5.8 \\
\hline${ }^{103} \mathrm{Ru}$ & 27 & $\cdots$ & $0.25 \pm 0.10 \mathrm{nCi} / \mathrm{m}^{2}$ & $<\mathrm{MDA}$ & 1.6 \\
\hline Natural gamma & 26 & $\cdots$ & $8.3 \pm 0.53 \mu \mathrm{R} / \mathrm{h}$ & 3.7 & 15 \\
\hline Total gamma & 26 & $\cdots$ & $8.9 \pm 0.55 \mu \mathrm{R} / \mathrm{h}$ & 4.1 & 16 \\
\hline${ }^{40} \mathrm{~K}$ & 27 & -.- & $19 \pm 1.1 \mathrm{pCi} / \mathrm{g}$ & 9.9 & 31 \\
\hline${ }^{232} \mathrm{Th}$ & 27 & $\ldots$ & $1.20 \pm 0.12 \mathrm{pCi} / \mathrm{g}$ & 0.31 & 2.8 \\
\hline${ }^{238} \mathrm{U}$ & 27 & $\cdots$ & $0.94 \pm 0.05 \mathrm{pCi} / \mathrm{g}$ & 0.43 & 1.7 \\
\hline \multirow[t]{3}{*}{${ }^{238} \mathrm{Pu}$} & 12 & 0.5 & $0.018 \pm 0.005 \mathrm{pCi} / \mathrm{g}$ & $<\mathrm{MDA}$ & 0.06 \\
\hline & 8 & $5-10$ & $0.008 \pm 0.005 \mathrm{pCi} / \mathrm{g}$ & $<\mathrm{MDA}$ & 0.03 \\
\hline & 6 & $10-15$ & $<M D A$ &.-- & --- \\
\hline${ }^{239,240} \mathrm{Pu}$ & 1 & $0-2.5$ & $0.77 \mathrm{pCi} / \mathrm{g}$ & $\ldots$ & $\ldots$ \\
\hline$(1950)$ & 8 & $0-2.5$ & $0.94 \pm 0.46 \mathrm{pCl} / \mathrm{g}$ & $<\mathrm{MDA}$ & 4.1 \\
\hline$(1973)$ & 24 & $0-5$ & $\begin{array}{c}3.2 \pm 0.88 \mathrm{nCi} / \mathrm{m}^{2} \\
(0.046 \mathrm{pCi} / \mathrm{g})^{\mathrm{c}}\end{array}$ & 0.32 & 21 \\
\hline \multirow[t]{3}{*}{ (1977) } & 14 & $0-5$ & $0.30 \pm 0.009 \mathrm{pCi} / \mathrm{g}$ & $<\mathrm{MDA}$ & 1.2 \\
\hline & 9 & $5-10$ & $0.15 \pm 0.08 \mathrm{pCi} / \mathrm{g}$ & $<M D A$ & 1.5 \\
\hline & 8 & $10-15$ & $0.008 \pm 0.005 \mathrm{pCi} / \mathrm{g}$ & $<\mathrm{MDA}$ & 0.04 \\
\hline \multirow[t]{4}{*}{${ }^{90} \mathrm{Sr}$} & 4 & $0-5$ & $1.47 \pm 0.68 \mathrm{pCi} / \mathrm{g}$ & 0.71 & 3.5 \\
\hline & 1 & $5-10$ & $2.16 \mathrm{pCi} / \mathrm{g}$ & $\ldots$ & $\ldots$ \\
\hline & 1 & $10-15$ & $0.30 \mathrm{pCi} / \mathrm{g}$ & $\cdots$ & $\cdots$ \\
\hline & 1 & $20-25$ & $0.21 \mathrm{pCi} / \mathrm{g}$ & $\cdots$ & $\cdots$ \\
\hline \multirow[t]{3}{*}{${ }^{137} \mathrm{Cs}$} & 10 & $0-5$ & $2.0 \pm 0.19 \mathrm{pCi} / \mathrm{g}$ & 0.95 & 3 \\
\hline & 5 & $5-10$ & $0.24 \pm 0.19 \mathrm{pCi} / \mathrm{g}$ & $<\mathrm{MDA}$ & 1.0 \\
\hline & 4 & $10-15$ & $\angle \mathrm{MDA}$ & -- & $\ldots$ \\
\hline
\end{tabular}

aS.E. - Standard Error.

${ }^{\mathrm{b}} \angle \mathrm{MDA}=$ less than minimum detectable activity.

${ }^{\mathrm{c}}$ Calculation of the $\mathrm{pCi} / \mathrm{g}$ is based on $0.0143(\mathrm{pCi} / \mathrm{g}) /\left(\mathrm{nCi} / \mathrm{m}^{2}\right)$. 
TABLE XIX

SAN ANTONIO AREA SURFACE SOIL MEASUREMENTS

\begin{tabular}{|c|c|c|c|c|c|}
\hline Radionuclide & $\mathbf{N}$ & $\begin{array}{l}\text { Depth } \\
\text { (cm) }\end{array}$ & Mean \pm S.E. ${ }^{8}$ & Min & $\operatorname{Max}$ \\
\hline${ }^{7} \mathrm{Be}$ & 9 & --- & $3.9 \pm 2.0 \mathrm{nCi} / \mathrm{m}^{2}$ & $<\mathrm{MDA}^{\mathfrak{a}}$ & 14.6 \\
\hline${ }^{60} \mathrm{Co}$ & 9 & $\cdots$ & $9.7 \pm 6.0 \mathrm{nCi} / \mathrm{m}^{2}$ & $<\mathrm{MDA}$ & 50 \\
\hline${ }^{137} \mathrm{Cs}$ & 9 & -- & $67 \pm 20 \mathrm{nCi} / \mathrm{m}^{2}$ & $<\mathrm{MDA}$ & 220 \\
\hline${ }^{99} \mathrm{Nb}$ & 9 & -- & $2.0 \pm 0.3 \mathrm{nCi} / \mathrm{m}^{2}$ & $<\mathrm{MDA}$ & 3.5 \\
\hline${ }^{99} \mathrm{Z}$ & 9 & $\cdots$ & $1.5 \pm 0.33 \mathrm{nCi} / \mathrm{m}^{2}$ & $<\mathrm{MDA}$ & 2.6 \\
\hline Natural gamma & 9 & --- & $7.5 \pm 0.6 \mu R^{\prime} h$ & 4.5 & 9.9 \\
\hline Total gamma & 9 & -- & $7.7 \pm 0.5 \mu \mathrm{R} / \mathrm{h}$ & 5.1 & 9.9 \\
\hline${ }^{40} \mathrm{~K}$ & 9 & $\cdots$ & $15 \pm 1.4 \mathrm{pCi} / \mathrm{g}$ & 7.2 & 19.7 \\
\hline${ }^{2 \vdots 2} \mathrm{Th}$ & 9 & --- & $0.83 \pm 0.12 \mathrm{pCi} / \mathrm{g}$ & 0.14 & 1.32 \\
\hline${ }^{238} \mathrm{U}$ & 0 & $\ldots$ & $1.2 \pm 0.13 \mathrm{pCi} / \mathrm{g}$ & 0.67 & 2.0 \\
\hline${ }^{239.240} \mathrm{Pu}$ & 4 & $0-5$ & $0.01 \pm 0.004 \mathrm{pCi} / \mathrm{g}$ & $<M D A$ & 0.02 \\
\hline${ }^{239,240} \mathrm{Pu}$ & 4 & $5-10$ & $0.003 \pm 0.003 \mathrm{pCi} / \mathrm{g}$ & $<M D A$ & 0.01 \\
\hline${ }^{239.240} \mathrm{Pu}$ & 4 & $10-15$ & $<\mathrm{MDA}$ & $-\cdots$ & --- \\
\hline
\end{tabular}

aS.E. - Standard Error.

${ }^{\mathrm{b}}<\mathrm{MDA}=$ less than minimum detectable activity. 
TABLE XX

AREAL CONCENTRATIONS OF ${ }^{137} \mathrm{Cs}$

\begin{tabular}{|c|c|c|c|}
\hline Location & $\begin{array}{c}\text { Mean } \\
\left(\mathrm{nCi} / \mathrm{m}^{2}\right) \\
\end{array}$ & Min & Max \\
\hline \multicolumn{4}{|l|}{ Trinity Fallout Areas } \\
\hline WSMR & $8104 \pm 3772$ & 488 & 23000 \\
\hline Bingham & $52 \pm 18$ & 34 & 69 \\
\hline Chupadera Mesa & $280 \pm 30$ & 30 & 947 \\
\hline Far Fallout Zone & $152 \pm 34$ & 10 & 765 \\
\hline Central NM & & & \\
\hline San Antonio & $67 \pm 20$ & $<\mathrm{MDA}$ & 220 \\
\hline Other Areas of U.S. & & & \\
\hline Amarillo, $\mathrm{TX}^{\mathrm{a}}$ & $148 \pm 32$ & $b$ & b \\
\hline Burlington, $\mathrm{IA}^{\mathrm{a}}$ & $105 \pm 34$ & $b$ & b \\
\hline Diablo Canyon, $\mathrm{CA}^{\mathrm{C}}$ & 105 & 100 & 110 \\
\hline Humboldt Bay, $\mathrm{CA}^{\mathrm{c}}$ & 32 & $\mathrm{~b}$ & \\
\hline San Clemente, $\mathrm{CA}^{\mathrm{c}}$ & 19 & 8 & 36 \\
\hline La Crosse. Wi ${ }^{\mathrm{c}}$ & 139 & 114 & 164 \\
\hline Baxley, $G^{c}$ & 60 & 41 & 79 \\
\hline Daisey, $\mathrm{TN}^{\mathrm{c}}$ & 168 & 146 & 190 \\
\hline Waterford. $\mathrm{CN}^{\mathrm{c}}$ & 305 & $\mathrm{~b}$ & b \\
\hline
\end{tabular}

${ }^{a}$ See Reference 28.

bSingle data point reported.

'See Reference 29. 


\section{TABLE XXI}

\section{CHUPADERA MESA IN SITU ${ }^{137} \mathrm{Cs}$ DATA FOR SOILS}

BY LAND FORM $\left(\mu \mathrm{Ci} / \mathrm{m}^{2}\right)$

\begin{tabular}{|c|c|c|}
\hline Location & $\begin{array}{c}\text { Slope } \\
\text { Above Drainage } \\
\end{array}$ & $\begin{array}{l}\text { Closed Drainage } \\
\text { Collection Point } \\
\end{array}$ \\
\hline \multirow[t]{2}{*}{ Cuate Tank } & 388 & 756 \\
\hline & -- & 547 \\
\hline \multirow[t]{3}{*}{ Three Peaks Area } & 261 & 947 \\
\hline & 314 & 410 \\
\hline & -- & 590 \\
\hline \multirow[t]{4}{*}{ Airca 21} & 338 & 545 \\
\hline & 428 & 512 \\
\hline & 308 & --- \\
\hline & 428 & --- \\
\hline \multirow[t]{4}{*}{ High Point on Mesa } & 602 & 540 \\
\hline & $X_{5}=383$ & $x_{D}=605$ \\
\hline & S.E. $=38$ & S.E. $=59$ \\
\hline & \multicolumn{2}{|c|}{$\begin{array}{c}H: X_{s}=X_{D} \\
t=-3.16\end{array}$} \\
\hline
\end{tabular}


TABLE XXII

${ }^{90} \mathrm{Sr}$ BACKGROUND INFORMATION

\begin{tabular}{|c|c|c|c|c|c|}
\hline Location & $\begin{array}{c}\text { Fallout } \\
\text { Conc }{ }^{90} \mathrm{Sr} \\
\left(\mu \mathrm{Ci} / \mathrm{m}^{2}\right) \\
\end{array}$ & $\begin{array}{c}1959-1976 \\
\text { Rainfall } \\
(\mathrm{cm}) \\
\end{array}$ & \multicolumn{2}{|c|}{$\begin{array}{c}\text { Latitude and } \\
\text { Longitude }\end{array}$} & $\begin{array}{c}\text { Altitude } \\
\text { (m) } \\
\end{array}$ \\
\hline Denver & 41.21 & 692.73 & $39^{\circ} 46^{\prime}$ & $104^{\circ} 53^{\prime}$ & 1611 \\
\hline Salt Lake City & 91.61 & 801.87 & $40^{\circ} 46^{\prime}$ & $110^{\circ} 49^{\prime}$ & 1516 \\
\hline$E^{\prime}$ Paso & 15.55 & 335.15 & $31^{\circ} 48^{\prime}$ & $106^{\circ} 48^{\prime}$ & 1204 \\
\hline Houston & 36.40 & 2186.86 & $29^{\circ} 39^{\prime}$ & $95^{\circ} 17^{\prime}$ & 22 \\
\hline Dallas & 40.24 & 1300.49 & $32^{\circ} 51^{\prime}$ & $96^{\circ} 51^{\prime}$ & 160 \\
\hline Chupadera Mesa & $\begin{array}{l}688 \\
\text { to }\end{array}$ & $\begin{array}{r}365 \\
\text { to }\end{array}$ & $\begin{array}{c}33^{\circ} 40^{\prime} \\
\text { to }\end{array}$ & $\begin{array}{c}105^{\circ} 40^{\prime} \\
\text { to }\end{array}$ & $\begin{array}{c}1524 \\
\text { to }\end{array}$ \\
\hline Far Fallout Zone & 384 & 914 & $34^{\circ} 20^{\prime}$ & $106^{\circ} 30^{\prime}$ & 2450 \\
\hline
\end{tabular}


TABLE XXIII

\section{POTENTIAL CONTRIBUTIONS OF RESUSPENSION TO ${ }^{239} \mathrm{Pu}$ AIRBORNE RADIOACTIVITY}

\begin{tabular}{ccc}
$\begin{array}{c}{ }^{239} \mathrm{Pu} \\
\text { Concentration } \\
\left(\mathrm{aCi} / \mathrm{m}^{3}\right)\end{array}$ & $\begin{array}{c}\text { Per Cent } \\
\text { DOE } \\
\text { Concentration } \\
\text { Guide }\end{array}$ & $\begin{array}{c}\text { Per Cent of } \\
\text { Proposed EPA } \\
\text { Derived Limit }\end{array}$ \\
\hline
\end{tabular}

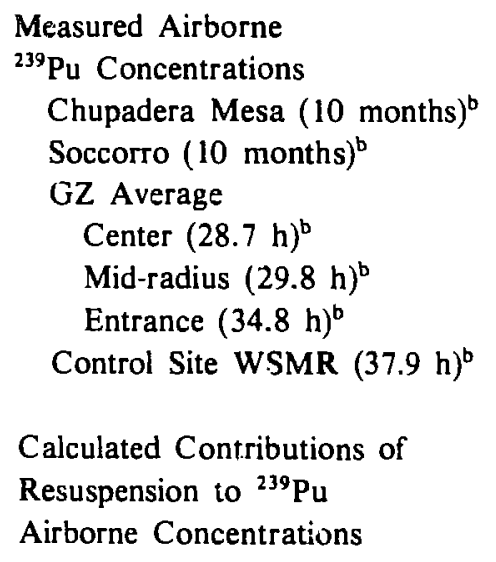

$\begin{array}{cll}43 & 0.0043 & 4.3 \\ 41 & 0.0041 & 4.1 \\ 63 & 0.0063 & 6.3 \\ 3 & 0.0003 & 0.3 \\ 1.2 & 0.00012 & 0.1 \\ 1.1 & 0.00011 & 0.1\end{array}$

GZ

White Sands Fallout Area

38

0.0038

3.8

Bingham

0.0022

2.2

22
7

0.0007

0.7

Chupadera Mesa

120

0.012

12

Far Fallout Zone

22

0.0022

Range of ${ }^{239} \mathrm{Pu}$ from Worldwide Fallout, 1974-1978, at Santa Fe, NM

Low (1976)

5-Year Average

High (1978)
3.8

16

24
0.006

0.03

0.04
0.4

1.6

2.4

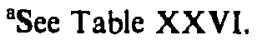

'Sample time. 
TABLE XXIV

\section{EXTERNAL RADIATION EXPOSURE SUMMARY FOR IN SITU DATA}

White Sands South of GZ

(Los Alamos National Labora-

tory Control) 3 Miles South

Dise to Natural

Total External

GZ

White Sands Missile Range in

Fallout Path

Chupadera Mesa, Area 21, Los Alamos National Laboratory Study Area

30 miles from GZ)

Monte Puerto Ranch

Far Fallout Zone ( $\sim 55$ miles NE from GZ)
Due to Natural

Total External

${ }^{137} \mathrm{Cs}$

Due to Natural Total External ${ }^{137} \mathrm{Cs}$

Due to Natural

Total External

Due to Natural
Total External
${ }^{137} \mathrm{Cs}$
${ }^{152} \mathrm{Eu}$

Due to Natural

Total External

${ }^{137} \mathrm{Cs}$

Others: ${ }^{60} \mathrm{Co},{ }^{152} \mathrm{Eu},{ }^{154} \mathrm{Eu}$

$$
9.3 \pm 0.17 \mu \mathrm{R} / \mathrm{h}
$$$$
9.8 \pm 0.23 \mu R / h
$$

$5.6 \pm 0.5 \mu \mathrm{R} / \mathrm{h}$

$175 \pm 1.1 \mu \mathrm{R} / \mathrm{h}$

$9.9 \pm 0.15 \mu \mathrm{R} / \mathrm{h}$

$137 \pm 0.7 \mu \mathrm{R} / \mathrm{h}$

$8.1 \pm 0.26 \mu \mathrm{R} / \mathrm{h}$ $22 \pm 0.3 \mu \mathrm{R} / \mathrm{h}$ $1.8 \pm 0.03 \mu R / h$ $13.1 \mu \mathrm{R} / \mathrm{h}$
$6.0 \pm 0.14 \mu \mathrm{R} / \mathrm{h}$ $8.1 \pm 0.14 \mu R / h$ $2.0 \pm 0.03 \mu \mathrm{R} / \mathrm{h}$

$8.2 \pm 0.13 \mu \mathrm{R} / \mathrm{h}$ $9.8 \pm 0.14 \mu \mathrm{P} / \mathrm{h}$ $1.5 \pm 0.02 \mu \mathrm{R} / \mathrm{h}$

$6.8 \pm 0.28 \mu \mathrm{R} / \mathrm{h}$ $7.5 \pm 0.28 \mu \mathrm{R} / \mathrm{h}$ 
TABLE XXV

EXTERNAL PENETRATING RADIATION MEASUREMENTS AND ESTIMATES OF CONTRIBUTIONS FROM TRINITY FALLOUT ( $\mu \mathrm{rem} / \mathrm{h})$

\begin{tabular}{|c|c|c|}
\hline Location & Measurement & $\begin{array}{c}\text { Estimated Contribution } \\
\text { Above Background }\end{array}$ \\
\hline \multicolumn{3}{|l|}{ GZ } \\
\hline Center Maximum & $485 \pm 4$ & 477 \\
\hline Inner Fence & $205 \pm 61$ & 187 \\
\hline Outer Fence & $10.8 \pm 2.5$ & 3.1 \\
\hline White Sands Missile Range & $7.8 \pm 0.6$ & 0.1 \\
\hline Bingham & $5.8 \pm 0.1$ & 0.2 \\
\hline Chupadera Mesa & $8.2 \pm 0.32$ & 1.5 \\
\hline Far Fallout Zone & $8.9 \pm 0.55$ & 0.6 \\
\hline
\end{tabular}




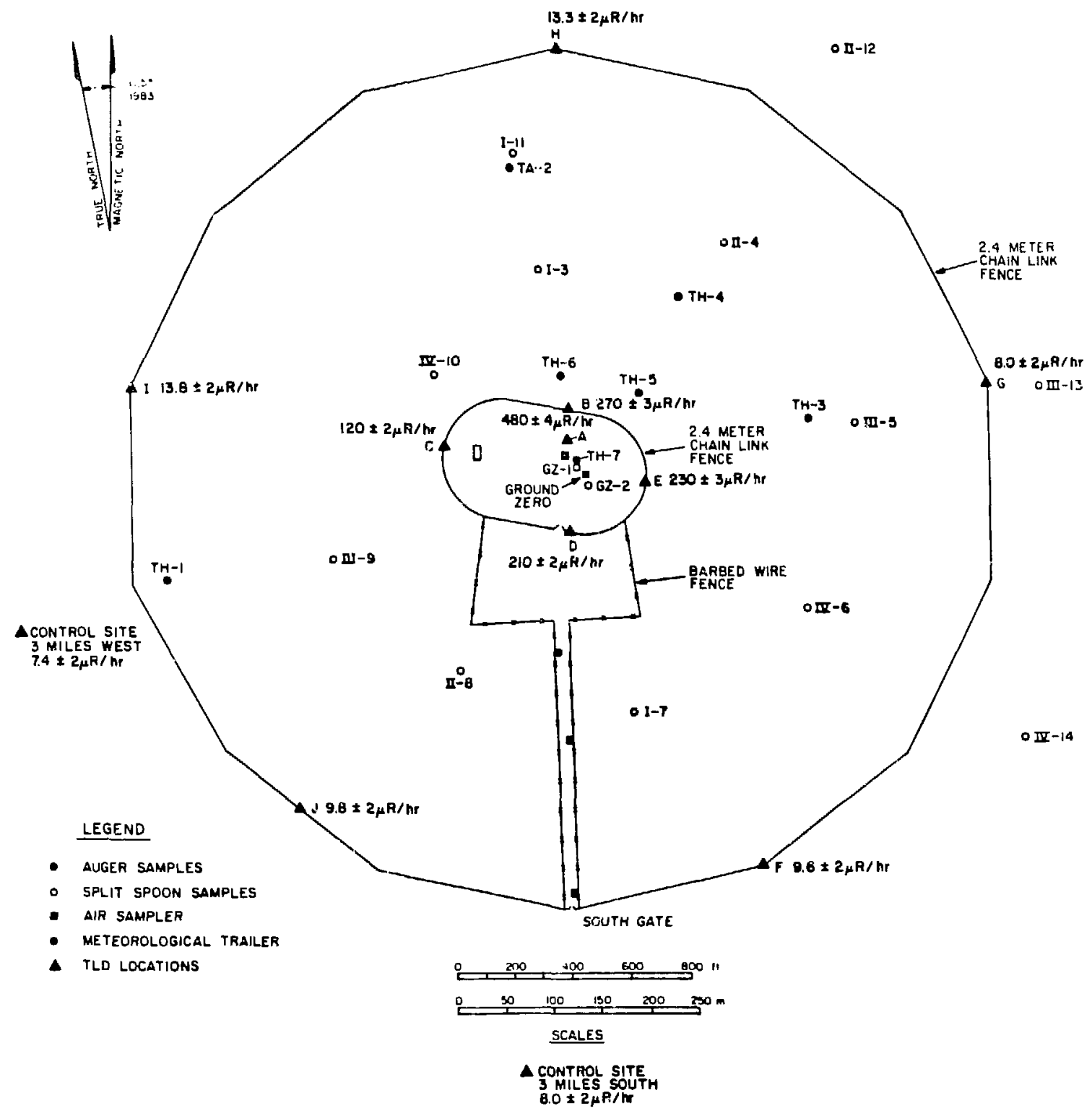

Fig. 11. External radiation dose rates measured at Trinity Site, June 9, 1983 to June 23, 1983. 


\section{POTENTIAL DOSE EVALUATION AND INTERPRETATION}

The significance of the data on concentrations of radioactivity on soils and sediments, radioactivity on airborne particulates, and external penetrating radiation may be evaluated in terms of the doses that can be received by people exposed to the conditions. The doses can be comparcd with natural background and appropriate standards or guides for one type of perspective. The doses can also be used to estimate risks or probabilities of health effects to an individual, providing another type of perspective more readily compared with other risks encountered. This section summarizes the analysis of potential doses and risk estimates. The detailed analysis is presented in Appendix D. Readers desiring more information on concepts of radioactivity, radiation, and dose interpretation may be helped by Appendix E, Evaluation of Radiation Exposures.

\section{BASES OF DOSE ESTIMATES AND COM- PARISONS}

Doses were calculated for various pathways that could result in the inhalation or ingestion of radioactivity. The calculations were based on theoretical models or factors from standard references and health physics liter dture as detailed in Appendix D. The doses are expressed in fractions of rems, where a millirem (mrem) is $1 / 1000$ of a rem, and a microrem ( $\mu \mathrm{rem}$ ) is $1 / 1000000$ of a rem. They are generally expressed as dose rates, that is, the radiation dose received in a particular time interval. The rem is a unit that permits direct comparison of doses from different sources, such as $x$ rays, gamma rays, and alpha particles, by accounting for the differences in biological effects from the energy absorbed from differen: radiations and isotope distributions. These doses can be compared with the DOE Radiation Protection Standards shown in Table XXVI, which are expressed as the permissible dose or dose commitment in addition to natural background radiation and medical exposures. First-year doses represent the dose received during the first year that a given radioactive isotope is ingested or inhaled. Because most of the isotopes of concern in this study are retained in various organs in the bod, for more than a year, 50-year Juse commitments were also calculated. The 50-year dose commitments represent the total dose that would be accumulated in the body or specific critical organs over a 50-year period from ingestion or inhalation during the first year. (Alternatively, the numerical values can also be interpreted to represent the annual dose rate during the 50th year given continuous exposure over all 50 years.) The 50 -year commitments are always as large or larger than first-year doses. In this summary, only the 50-year commitments are compared with the standards.

Conceptually, this is in agreement with the recommendations of the International Commission on Radiolosical Protection (ICRP) that in effect charge the entire dose commitment against the year in which exposure occurs for regulatory purposes. ${ }^{30}$ The use of the 50 -year dose commitment also permits making estimates of risk over a lifetime from the given exposure and simplifies comparisons between different exposure situations.

The dose commitments were calculated using published factors (Appendix D). The dose models employed in the derivation of these factors are based primarily upon reports of the ICRP. Other methods of computing doses are available. Additionally, there are conceptually different approaches emphasizing the dose at the time of maximum dose rate following exposure as the basis for comparison with standards. ${ }^{31-33}$ This is significant for isotopes such as plutonium that accumulate in certain parts of the body and can lead to a constantly ircreasing dose rate under conditions of chronic exposure. One such approach has been proposed by the EPA as guidance for Federal agencies in regard to plutonium. ${ }^{29}$ These other . approaches do not yield dose estimates or comparisons with standards sufficiently different from the methods used in this report to make any significant difference in the conclusions drawn for the radionuclides of concern in this evaluation. For example, under conditions of chronic exposure to ritborne ${ }^{239} \mathrm{Pu}$, the radiation dose in the year of maximum dose rate (taken to be the 70th year) calculated by the methods of Healy or the EPA would give organ-specific estimates ranging from about $1 / 4$ (for bone) to 2.6 (for lung) times the values given in this 
TABLE XXVI

STANDARDS AND GUIDES FOR RADIATION AND RADIOACTIVITY

DOE Radiation Protection Standards for

External and Internal Exposures ${ }^{2}$

Individuals and Population Groups in Uncontrolled Areas

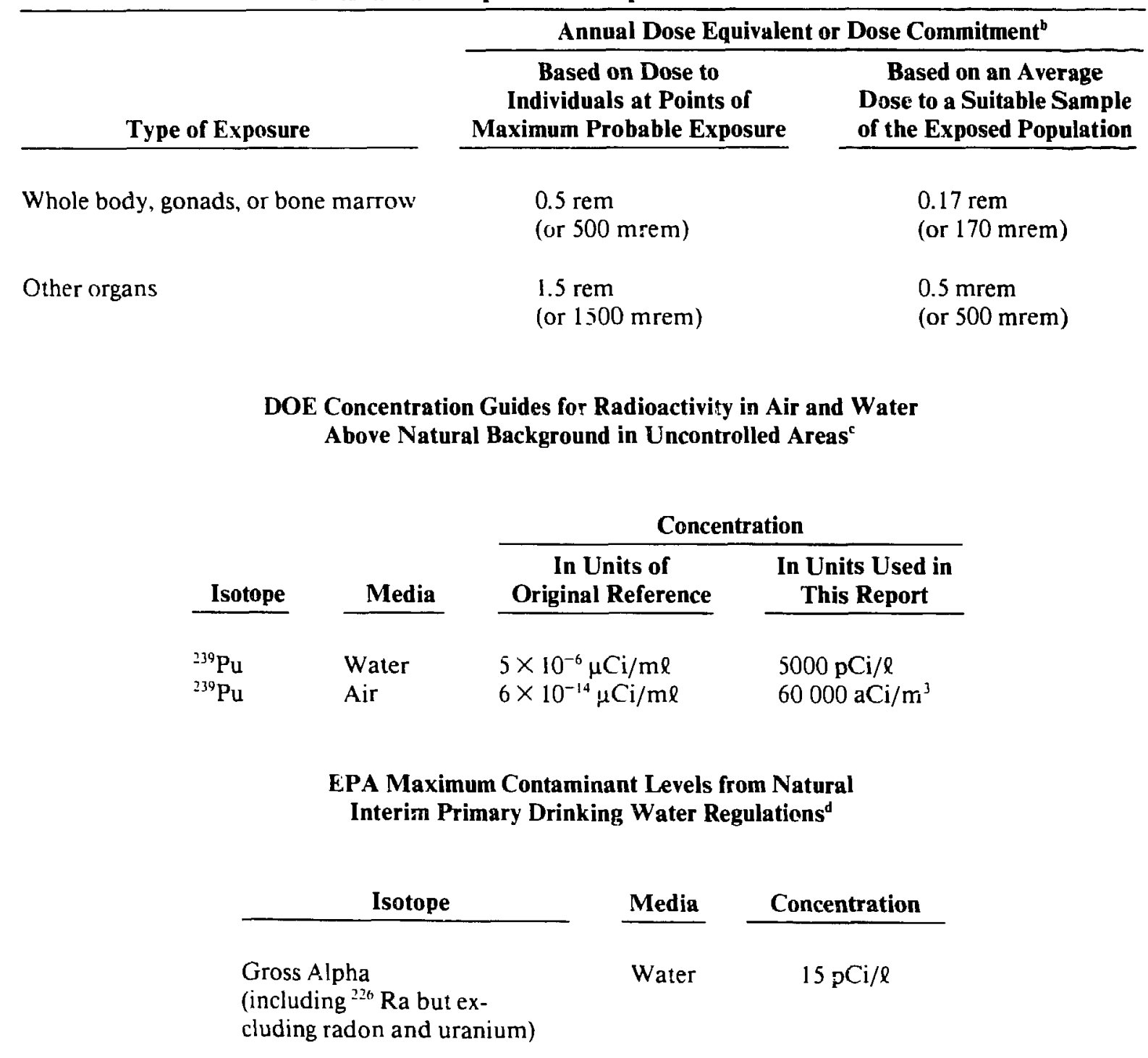




\title{
TABLE XXVI (cont)
}

\section{EPA Proposed Guidance on Dose Limits for Persons Exposed to Transuranium Elements in the General Environment ${ }^{e}$}

\author{
Maximum Annual Alpha Radiation Dose Rate \\ as Result of Exposure to Transuranium Elements: \\ $1 \mathrm{mrad} / \mathrm{yr}$ to pulmonary lung (approximately $10 \mathrm{mrem} / \mathrm{yr}$ ) \\ $3 \mathrm{mrad} / \mathrm{yr}$ to bone \\ (approximatley $150 \mathrm{mrem} / \mathrm{yr}$ )
}

Derived Air Concentration Reasonably Predicted to Result

in Dose Rates Less than the Guidance Recommendations:

$\frac{\begin{array}{c}\text { In Units of } \\ \text { Original Reference }\end{array}}{1000 \mathrm{aCi} / \mathrm{m}^{3}}$
$\begin{aligned} & \text { In Units Used in } \\ & \text { This Report }\end{aligned}$
$\begin{aligned} & \text { (for alpha emitting transuranium nuclides } \\ & \text { on an activity median aerodynamic particle } \\ & \text { diameter not to exceed } 0.1 \mu \mathrm{m} \text { ) }\end{aligned}$

aSee Reference 29.

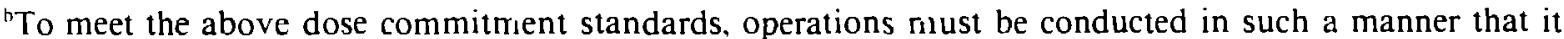
would be unlikely that an individual would assimulate in a critical organ, by inhalation, ingestion, or absorption, a quantity of a radionuclide(s) that would commit the individual to an organ dose exceeding the limits specified in the above table.

'See Reference 29.

dSee Reference 30.

"See Reference 18.

report. ${ }^{33,31}$ These factors are about the same size as other uncertainties in the data (see Chapter 4.I.A) and smaller than some of the intentionally overestimated assumptions incorporated in this evaluation. Thus there would be no significant changes in the relative ranking or order of magnitude of estimated doses and risks if othir methodologies were used.

The estimates of radiological risks from doses, presented in Table I of the summary chapter, were based on the risk factors recommended by the National Academy of Sciences. ${ }^{34}$ Multiplying an estimated dose and the appropriate risk factor yields an estimate of the probability of injury to the individual as a result of that exposure. The risk factors used are
For uniform whole-body dose

Cancer mortality

$1.2 \times 10^{-4}$ per rem whole body,

For specific organ doses

Lung cancer

$9 \times 10^{-3}$ per rem to lung,

Bone cancer

$3 \times 10^{-6}$ per rem to bone,

Liver cancer
$3 \times 10^{-9}$ per rem to liver. 
As an example, a whole-body dose of $10 \mathrm{mrem} / \mathrm{yr}(1.2 \times$ $10^{-2} \mathrm{rem} / \mathrm{yr}$ ) would be estimated to add a risk of cancer mortality to the exposed individual of $1.2 \times 10^{-6}$ per year of exposure, or about 1 chance in 1000000 per year of exposure.

Such risk estimates must be placed in appropriate contexts to be useful as a decision-making tool. One comparison is with other types of risks encountered in normal life that may result in early mortality. Table II (in Chapter 1) of this report presented a range of selected examples of activities and risks that increase chances of death. ${ }^{35,36}$ A second useful comparison is an estimate of the risk that can be attributed to natural background radiation. Radiation from various natural external and internal sources results in exactly the same types of interactions with body tissues as those from so-called "mannade" radioactivity. Thus, the risks from a given dose are the same regardless of the source.

Natural background radiation for people in the environment consists of the external penetrating dose from cosmic and terrestrial sources, cosmic neutron radiation, and self-irradiation from natural isotopes in the body. The several-year average for external penetrating radiation measured by a group of 12 perimeter stations located mainly in the Los Alamos area of New Mexico is about $117 \mathrm{mrem} / \mathrm{yr}$. Cosmic neutrons contribute about 17 $\mathrm{mrem} / \mathrm{yr}$, and average self-irradiation, largely from natural radioactive potassium $\left({ }^{40} \mathrm{~K}\right)$, is about $24 \mathrm{mrem} / \mathrm{yr}$. These give a combined dose of about $158 \mathrm{mrem} / \mathrm{yr}$. Because of the variations in the terrestrial component with location and time of year, this value is probably valid to about $\pm 25 \%$ for most of the Los Alamos population. For purposes of comparison we will use a rounded value of $150 \mathrm{mrem} / \mathrm{yr}$ as typical natural background in the area. This can be interpreted, using the risk factors, :o represent a contribution to the risk of cancer mortality of $1.8 \times 10^{-5}$ (18 chances in 1000000 ) for each year of exposure or a risk of $9 \times 10^{-4}$ ( 9 chances in 10000 ) in 50 years of exposure to natural background radiation. The natural radiation combined dose for ex ternal penetrating dose, cosmic neutron dose, and selfirradiation from internally deposited radionuclides is estimated to be $106 \mathrm{mrem} / \mathrm{yr}$ for persons living in the Far Fallout Zone. This would represent a contribution to the risk of cancer mortality of $1.3 \times 10^{-5}$ (18 chances in 1000000 ) for each year of exposure or a risk of $6 \times 10^{-4}$ ( 6 chances in 10000 ) in 50 years of exposure to natural background in that area. As perspective, estimates of the overall U.S. population lifetime risk of mortality from cancer induced by all causes are currently about $0.2(2$ chances in 10.)

\section{POTENTIAL DOSES FROM THE CURRENT CONDITIONS IN THE TRINITY TEST FALL- OUT DEPOSITION AREAS}

The dose calculations made from the summary data in Chapter 4 are detailed in Appendix D. The overall summary of Appendix D dose estimates is presented in Table XXVII along with the DOE Radiation Protection Standards for whole-body and organ exposures. Also listed is the proposed Envi-onmental Protection Agency (EPA) guidance for transuranic elements in the cavironment, expressed in mrem/yr. Comparison of the estimated inhalation and ingestion doses with the DOE and EPA guidance indicates there is no cause for concern for individuals living full time in the uncontrolled areas of the fallout zone. However, the controlled GZ fenced areas still have enough residual radiation to exceed standards for uncontrolled areas; but the levels are less than the $5000 \mathrm{mrem} / \mathrm{yr}$ standard for controlled areas.

The controlled areas of the fenced $\mathrm{GZ}$ are within the larger controlled access area of White Sands Missile Range (Fig. 4). The fence around GZ is locked, with access controlled by the Army's Range Safety Officer and by Security. Public access is limited to a 2-h visit in the autumn of each year when the site is opened to visitors. Visitors are escorted to the site and back off the White Sands Missile Range. The dose to any member of the public would be less than 1 mrem during such a visit.

Other possible means of exposure involve Army personnel either as workers preparing for visitors or the daily security patrols that pass the GZ area outside the fence. Assuming personnel spend 1 week in the inner fenced area in preparation for visitors, the estimated dose would be about $8 \mathrm{mrem}$ total dose. Assuming the security patrol soends 1 hour per day all year checking the outer fence, the estimated dose is $0.75 \mathrm{mrem}$. These doses are $1.6 \%$ and $0.2 \%$, respectively, of the radiation protection standard for a member of the public.

\section{SPECIAL CONSIDERATIONS}

The GZ area of White Sands Missile Raııe was declared a National Historic Site in 1962. Any actions considered that alter current conditions will require consultation with the U.S. Army ard National Historic Preservation Council of the U.S. Department of the Interior. 
TABLE XXYII

INCREMENTAL DOSES

Mean Estemal

Whole Body Incrament above Natural Background (mrem/yr)

Inhulation Tolol from Resuspersion'
Whole Body Bone Lung Liver

mrenvyr (50. Year Commitied Dose)

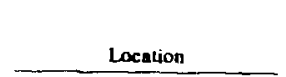

GZ

Inner Fence $=$

Between fences'

White Sands Missile Range ${ }^{c} 102$

Bingham

Chupadera Mess

Far Fallout Zone

San Antonio

17
876
14
1.7
13
5
1.7
500
$\cdots$

$\begin{array}{llll}0.028 & 0.29 & 0.30 & 0.14 \\ 0.0073 & 0.074 & 0.077 & 0.037 \\ 0.016 & 0.17 & 0.17 & 0.083 \\ 0.0049 & 0.051 & 0.053 & 0.025 \\ 0.088 & 0.91 & 0.95 & 0.45 \\ 0.016 & 0.17 & 0.17 & 0.083 \\ 0.00058 & 0.0056 & 0.0058 & 0.0028 \\ & & & \\ 500 & 1500 & 1500 & 1500\end{array}$

Radiation Protection Standard

EPA Proposed Guidance

"Major dose contributed by transuranics.

"Major dose contributed by transuranics and ${ }^{90 S r}$ (see Appendix D, Table D-XII).

'Equal time spent at high-dose rate and low-dose rale areas. Assumes $168 \mathrm{~h} / \mathrm{wk}, 52$ wk occupancy.

'Nol calculared because other in balation doses are 9 mall.

Investion Total from Foodt

Inpestion Total from Foods
Whok Body Bone Liver GI-LLI Whate Bady Bone Lung Liver

2.4
0.1
1.7
1.6
1.9
1.2
0.1
500

$\begin{array}{ccc}74 & 35 & 1.3 \\ 2.7 & 1.3 & 0.03 \\ 20 & 2.9 & 1.3 \\ 19 & 2.3 & 1.2 \\ 37 & 8.1 & 1.5 \\ 16 & 1.8 & 1.0 \\ 0.2 & 0.2 & 0.05 \\ 1500 & 1500 & 1500\end{array}$

1.3
0.03
1.3
1.2
1.5
1.0
0.05
00

500

\subsection{1}

$1.2 \quad 1.2$

$0.073 \quad 0.1^{7} \quad 0.18$

$\begin{array}{lll}0.039 & 0.40 & 0.42\end{array}$

0.40

0.083

0.86
0.19

$0.42 \quad 0.20$

$\begin{array}{ll}0.87 & 0.42 \\ 0.17 & 0.086\end{array}$

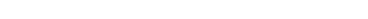




\section{REFERENCES}

1. Los Alamos Scientific Laboratory, Los Alamos: Beginning of an Era 1943-1945, Los Alamos Scientific Laboratory Public Relations Office, 64 p (1965).

2. Stafford L. Warren, "The 1948 Radiological Survey of Areas in New Mexico Affected by the First Atomic Bomb Detonation," University of California at Los Angeles report UCLA-32, Part 1 (November 17, 1949).

3. R. Overstreet, L. Jacobson, K. Larson, and G. Huntington, "Trinity Survey Program," Atomic Energy Project, University of California at Los Angeles report R3091 (November 1947).

4. K. H. Larson, J. L. Leitch, W. F. Dunn, J. W. Neel, J. H. Olafson, E. E. Held, J. Taylor, W. J. Cross, and A. W. Bellamy, "Alpha Activity Due to the 1945 Atomic Bomb Detonation at Trinity, Alamogordo, New Mexico," University of California at Los Angeles report UCLA-108 (February 1951).

5. J. L. Leitch, "Summary of the Radiological Findings in Animals from the Biological Surveys of 1947 , 1948, 1949, and 1951," University of California at Los Angeles report UCLA-111 (February 1951).

6. K. H. Larson, J. H. Olafson, J. W. Neel, W. F. Dunn, S. H. Gordon, and B. Gillooly, "The 1949 and 1950 Radiological Soil Survey of Fission Product Contamination and Some Soil Plant Interrelationships of Areas in New Mexico Affected by the First Atomic Bomb Detonation," University of California at Los Angeles report UCLA-140 (June 1951).

7. J. H. Olafson, H. Nishita, and K. H. Larson, "The Distribution of Plutonium in Soils of Central and Northeastern New Mexico as a Result of the Atomic Bomb Test of July 16, 1945," University of California at Los Angeles report UCLA-406 (September 1957).

8. D. B. Dunn and D. L. Spellman, "The Revegetation at the New Mexico Atomic Bomb Crater," University of Missouri report COO-1296-1 (February 1965).
9. T E. Hakonson and L. J. Johnson, "Distribution of Environmental Plutonium in the Trinity Site Ecosystem after 27 Years," Proceedings of the Third International Congress of the International Radiation Protection Association (IRPA, Washington, D.C., 1973), CONF-730907-P1, pp. 242-247.

10. J. W. Nyhan, F. R. Miera, Jr., and R. E. Neher, "Distribution of Plutonium in Trinity Soils after 28 Years," Journal of Environmental Quality, Vol. 5, No. 4, pp. $431-437$ (1976).

11. T. E. Hakonson and J. W. Nyhan, "Temporal Changes in Soil Plutonium Distribution in Trinity Site Environs," in "Biomedical and Environmental Research Program of the LASL Health Division, January-December 1976," Los Alamos Scientific Laboratory report LA-6898-PR (July 1977), pp. 84-85.

12. T. E. Hakonson and J. W. Nyhan, "A Comparisor of Plutonium Concentration and Inventory Ratios for some Ecosystcm Components in the United States," in "Biomedical and Environmental Research Program of the LASL Health Division, JanuaryDecember, 1977," Los Alamos Scientific Laboratory report LA-7254-PR (July 1978), pp. 3-4.

13. R. L. Douglas, "Levels and Distribution of Environmental Plutonium Around the Trinity Site," U.S. Environmental Protection Agency, Office of Radiation Programs, Las Vegas, Nevada report ORP/V-78-3, 42p. (October 1978).

14. T. E. Hakonson and J. W. Nyhan, "Ecological Relationships of Plutonium in Southwest Systems," in "Transuracic Elements in the Environment," W. C. Hanson, ed., U.S. Department of Energy report DOE/TIC-22800, pp. 403-419 (1980).

15. H. L. Beck, W. T. Condon, and W. M. Lowder, "Spectrometric Techniques for Measuring Environmental Gamma Radiation," U.S. Atomic Energy Commission Health and Safety Laboratory, New York report HASL-150 (1964).

16. H. L. Beck, J. de Campo, and C. Gogalak, "In-Situ $\mathrm{Ge}(\mathrm{Li})$ and $\mathrm{NaI}(\mathrm{Tl})$ Gamma Ray Spectrometry," U.S. Atomic Energy Commission Health and Safety Laboratory, New York report HASL-258 (1972). 
17. L. R. Anspaugh, P. L. Phelps, P. H. Gudiksen, C. L. Lindeksen, and G. W. Huckaby, "The In-Situ Measurement of Radioisotopes in the Environment with a $\mathrm{Ge}(\mathrm{Lj})$ Spectrometer," in The Natural Radiation Environment, II, J. A. S. Adams, W. M. Lowder, and T. S. Gesell, eds., Energy Research and Development Administration report CONF-72-0805-P1, pp. 279-304 (1972).

18. P. L. Phelps, L. R. Anspaugh, S. J. Roth, G. W. Huckaby, and D. L. Sawyer, "Ge(Li) Low Level InSitu Gamma-Ray Spectrometer Applications," IEEE Trans. on Nucl. Sci. NS-21(1), p. 543 (1974).

19. H. L. Ragsdale, B. K. Tanner, R. N. Coleman, J. M. Palms, and R. E. Wood, "In Situ Measurement of Some Gamma-Emitting Radionuclides in Plant Communities of the South Carolina Castac Plain," in Environmental Chemistry and Cycling Processes, Savannah River Ecology Laboratory report, Prepublication Copy, p. 1B-27B (1976).

20. R. Gunnik and J. B. Niday, "Computerized Quantitative Analysis by Gamma-Ray Spectroscopy, Vol. I, Description of the Gamanal Program," Lawrence Livermore Laboratory report UCRL-51061 (1972).

21. Environmental Surveillance Group, "Environmental Surveillance at Los Alc. nos During 1977," Los Alamos Scientific Laboratory report LA-7263-MS (April 1978).

22. Bureau of Radiological Health, Radiological Health Handbook, U.S. Department of Health, Education, and Welfare. Rockville, MD 20852, U.S. Government Printing Office, Washington, D.C. 20402, pp. $72-85$ (1970).

23. National Council on Radiation Protection and Measurements, "Natural Background Radiation in the United States," NCRP report No. 45, Washington, D.C. 20014 (November 1975).

24. W. M. Lowder, W. J. Condon, and H. L. Beck, "Field Spectrometric Investigations of Environmental Radiation in the USA," in The Natural Radiation Environment, J. A. S. Adams and W. M. Lowrler, eds., University of Chicago Press, Chicago. Illinois, pp. 597-616 (1964).
25. N. H. Nie, C. H. Hull, J. G. Jenkins, K. Steinbrenner, and D. H. Bent, SPSS: Statistical Packags for the Social Sciences, 2nd ed., McGraw-Hill, New York, NY (1975).

26. T. Buhl, J. Dewart, T. Gunderson, D. Talley, J. Wenzel, R. Roniero, J. Salazar, and D. Van Etten, "Supplementary Documentation for an Environmental Impact Statement Regarding the Yantex Plant: Radiation Monitoring and Radiological Assessment of Routine Releases," Los Alamos National Laboratory report LA-9445-PNTX-C (1982).

27. R. A. Mohr and I. A. Franks, "Compilation of ${ }^{137} \mathrm{Cs}$ Concenirations at Selected Sites in the Continental United States," EG\&G, Santa Barbara, California, EG\&G report 1183-2437 (1982).

28. U.S. Department of Energy, "Requirements for Radiation Protection: Concentrations in Air and Water Above Natural Background," DOE Order 5480.1, Chapter XI (August 1981).

29. U.S. Environmental Protection Agency, "Persons Exposed to Transuranium Elements in the Environment," Proposed Federal Radiation Protection Guidance on Dose Limits, in Federal Register, Vol. 42, No. 230, Wednesday, Nov. 30, 1977, pp. 60956-60959 (1977).

30. International Commission on Radiological Protection, "Limits for Intake of Radionuclides by Workers," Annals of the ICRP, Vol. 2, No. 3/4, ICRP Publication 30 (1979).

31. U.S. Environmental Protection Agency, "Proposed Guidance on Dose Limits for Persons Exposed to Transuranium Elements in the General Environment," U.S. EPA Office of Radiation Programs report EPA 540/4-77-016 (September 1977).

32. J. W. Healy, "A Proposed Interim Standard for Plutonium in Soils," Los Alamos Scientific Laboratory report LA-5483-MS (January 1974).

33. J. W. Healy, "An Examination of the Pathways from Soil to Man for Plutonium," Los Alamos Scientific Laboratory report LA-6741-MS (April 1977). 
34. U.S. Department of Energy, "Radiological Guidelines for Application to DOE's Formerly Utilized Sites Remedial Action Program," U.S. DOE, Oak Ridge Operations report ORO-831 (March 1983).

35. W. Wilson, "Analyzing the Daily Risks of Life," in Technology Review, Massachusetts Institute of Technology, pp. 41-46 (February 1979).
36. U.S. Nuclear Regulatory Commission, "Final Environmental Statement on the Transportation of Radioactive Material oy Air and Other Modes," Docket No. PR-71,73 (40FR23768), Office of Standards Development, UISNRC document NUREG0170, Vol. 1 (December 1977). 


\section{ACRONYMS AND ABBREVIATIONS}

\begin{tabular}{ll} 
AEC & Atomic Energy Commission \\
ALO & Albuquerque Operations Office \\
c & counts \\
cpm & counts per minute \\
CG & concentration guide \\
DOE & Department of Energy \\
EPA & Environmental Protection Agency \\
ERDA & Energy Research and Development Administration \\
FDA & Food and Drug Administration \\
FSD & Fractional Standard Deviation \\
FUSRAP & Formerly Utilized Sites Remedial Action Program \\
GZ & Ground Zero \\
ICRP & International Commission on Radiological Protection \\
LADB & Los Alamos Data Base \\
MDA & Minimum Detectable Activity \\
MED & Manhattan Engineer District \\
NCRP & National Council on Radiation Protection and Measuremtnts \\
NRC & Nuclear Regulatory Commission \\
OSHA & Occupational Safety and Health Administration \\
QA & quality assurance \\
RCG & Radioactivity Concentration Guide \\
rem & roentgen equivalent man \\
RPS & Radiation Protection Standard \\
TLD & thermoluminescent dosimeter \\
TRU & transuranic \\
TSS & total suspended solids \\
USGS & United States Geological Survey \\
WSMR & White Sands Missile Range \\
& \\
a & alpha \\
$\beta$ & beta \\
$\gamma$ & gamma \\
s & standard deviation \\
-6 & mean \\
& \\
\hline &
\end{tabular}




\section{UNITS}

\begin{tabular}{|c|c|}
\hline Abbreviation & Unit \\
\hline c & count \\
\hline $\mathrm{aCl}$ & attocurie $\left(10^{-18}\right.$ curies $)$ \\
\hline $\mathrm{Ci}$ & curie (unit of radioactivity) \\
\hline $\mathrm{cm}$ & centimeter \\
\hline $\mathrm{cpm} / \mathrm{l}$ & counts per min per liter \\
\hline $\mathrm{fCi}$ & fcmtocurie ( $10^{-15}$ curies $)$ \\
\hline $\mathrm{ft}$ & foot \\
\hline g & gram \\
\hline $\mathrm{h}$ & hour \\
\hline in. & inch \\
\hline keV & kiloelectron volt \\
\hline $\mathrm{kg}$ & kilogram \\
\hline $\mathrm{km}$ & kilometer \\
\hline $\mathrm{km}^{2}$ & square kilometer \\
\hline$\ell$ & liter \\
\hline $\mathrm{m}$ & meter \\
\hline $\mathrm{m}^{3}$ & cubic meter \\
\hline $\mathrm{mCi}$ & millicurie $\left(10^{-3}\right.$ curies $)$ \\
\hline $\mathrm{MeV}$ & megaelectron volt \\
\hline $\mathrm{mg}$ & milligram $\left(10^{-3}\right.$ grams $)$ \\
\hline $\min$ & minute \\
\hline $\mathrm{ml}$ & milliliter $\left(10^{-3} \ell\right)$ \\
\hline $\mathrm{mm}$ & millimeter $\left(10^{-3}\right.$ meter $)$ \\
\hline mrem & millirem $\left(10^{-3} \mathrm{rem}\right)$ \\
\hline $\mathrm{mS} / \mathrm{m}$ & milliSiemens $/$ meter $(1 \mathrm{mS} / \mathrm{m}=10 \mu \mathrm{mho} / \mathrm{cm})$ \\
\hline MGD & million gallons per day \\
\hline MT & megaton ( $10^{6}$ tons) \\
\hline$\mu \mathrm{Ci}$ & microcurie ( $10^{-6}$ curies) \\
\hline$\mu \mathrm{g}$ & microgram (10-6 grams) \\
\hline$\mu \mathrm{m}$ & micrometer ( $10^{-6}$ meters) \\
\hline $\mathrm{nCi}$ & nanocurie $\left(10^{-9}\right.$ curies $)$ \\
\hline $\mathrm{pCi}$ & picocurie $\left(10^{-12}\right.$ curies $)$ \\
\hline $\mathbf{R}$ & Roentgen \\
\hline $\mathrm{rad}$ & $62.5 \times 10^{6} \mathrm{MeV} / \mathrm{g}$ (unit of absorbed dose) \\
\hline rem & roentgen equivalent man (unit of dose equivalence) \\
\hline s & second \\
\hline yr & year \\
\hline
\end{tabular}




\section{GLOSSARY}

alpha particle

beta particle

\section{CG (Concentration Guide)}

Curie

gamma radiation (or $\mathrm{x}$ radiation)

arithmetic mean

geometric mean

gross alpha

gross beta

rad

roentgen
A charged particle (identical to the helium nucleus) composed of two protons and two neutrons that is emitted during decay of certain radioactive atoms. Aipha particles are stopped by several centimeters of air or a sheet of paper.

A charged particle (identical to the electron) that is emitted during decay of certain radioactive atoms. Most beta particles are stoppped by $0.6 \mathrm{~cm}$ of aluminum or less.

The concentration of radioactivity in air or water that is determined to result in whole-body or organ doses equal to ERDA's Radiation Protection Standards for cxternal and internal exposures if the air is continuously inhaled or the water is the solc source of liquid nourishmeni throughout the year.

A special unit of radioactivity. One curie equals $3.70 \times$ $10^{10}$ nuclear transformations per second (abbreviated $\mathrm{Ci}$ ).

Short-wavelength electromagnetic radiation of nuclear origin that has no mass or charge. Because of its short wavelength, gamma radiation can cause ionization. Other electromagnetic radiation (microwaves, visible light, radiowaves, etc.) has longer wavelengths (lower energy) and cannot cause ionization.

The average of $\mathrm{n}$ given numbers obtained by dividing their sum by $n$.

The average of $n$ given numbers obtained as the $n$th root of their product.

The totai amount of measured alpha activity.

The total amount of measured beta activity.

The unit of absorbed radiation dose. It applies to the fraction of energy deposited by ionizing radiation in a unit volume of material exposed. 1 Rad $=1 \times 10^{-2}$ Joules per kilogram.

The unil of radiation exposure (abbreviated $R$ ). It applies only to the amount of charge produced by $x$ or gamma radiation in ai , $I R=2.58 \times 10^{-4}$ coulombs per kilogram. 
rem

RPS (Radiation Protection Standard)

total uranium
The unit of radiation dose equivalence that takes into account different effects on humans of various kinds of ionizing radiation and permits them to be expressed on a common basis.

DOE standards for external and internal exposure to radioactivity as defined in DOE Order 5480.

Uranium having the isotopic content of uranium in nature $\left(99.27 \%{ }^{238} \mathrm{U}, 0.72 \%{ }^{235} \mathrm{U}, 0.0057 \%{ }^{234} \mathrm{U}\right)$. 


\section{APPENDIX A}

\section{DATA BASE TRINDAT}

The following computer printout conteins the combined data from the several studies of environmental levels of radioactivity through 1977 . The printout contains 10 columns of information regarding each sample. The following provides a key to the information in each column:

Column 1-Sample number. "Tag Words" are discussed in Appendix B. The sample numbers greater than 1000 are for a given location from the 1977 survey. Appen$\mathrm{dix} B$ is a field log describing each location.

Column 2-Radionuclide analyzed for in the sample or type of radiation measured (G-NAT = natural gamma dose).

Column 3-Date of the determination.

Column 4-Type of Sample.

INSITU-Field in situ gamma-ray spectroscopy by Lawrence Livermore Laboratory system.

JP-one-seeded juniper

GR-grasses

SK-snakeweed

TH-Thistle

UK-Unknown vegetation

SG-mixed snakeweed and grasses

SOIL-Soil sample. Column 5 contains information on depth.

Column 5-Midpoint of depth from surface of soil samples. Examples: 2.5 is for 0 - to 5 -cm sample; 7.5 is for $5-$ to $10-\mathrm{cm}$ sample, and 12.5 is for $10-$ to $15-\mathrm{cm}$ sample.

Columns 6 and 7-Arbitrary coordinates from a base map of sample locations. Used for computer graphics in Chapter 4.
Column 8-Value of radionuclide concentration or penetrating radiation dose.

Column 9-Units for amount of radionuclide or radiation dose.

Column 10-Laboratory or agency that conducted determination:

LASL77-Now Los Alamos National Laboratory; associated with in situ determinations.

LLL GELI-Samples counted at Lawrence Livermore National Laboratory.

LASLCHEM-Sample determination made by Los Alamos National Laboratory Environmental Surveillance Chemistry Section.

CVEG-Vegetation content by same group as LASLCHEM.

EPA-Environmental Protection Agency determination.

UCLA-University of California at Los Angeles studies of 1948 and 1950.

LASL72-Samplings by Los Alamos Scientific Laboratory in 1972.

With the large amount of data present in TRINDAT, much more information than covered by this report can be recovered from the data base. The last item to be identified is the label associated with PU239 as INSITU in Column 4 and PREDICTED in Column 10. Those data were calculated from known amounts of ${ }^{137} \mathrm{Cs}$ in situ measurements and ${ }^{239-240} \mathrm{Pu}$ soil samples at a number of locations. Both ${ }^{137} \mathrm{Cs}$ and plutonium isotopes are 
strongly retained in the top few centimeters of soils. If there were a strong correlation between ${ }^{137} \mathrm{Cs}$ and ${ }^{339-240} \mathrm{Pu}$ in soils, a few ${ }^{239-240} \mathrm{Pu}$ radiochemical determinations could establish the relationship with ${ }^{137} \mathrm{Cs}$. Determination of ${ }^{137} \mathrm{Cs}$ by relatively inexpensive in situ measurements could be used for ${ }^{239-240} \mathrm{Pu}$ estimates at other sampling points in lar $y_{\text {- }}$ areas. The "predicted" data in TRINDAT were not used for any of the estimates in this report, but the method has enough promise to merit further development in the future. 


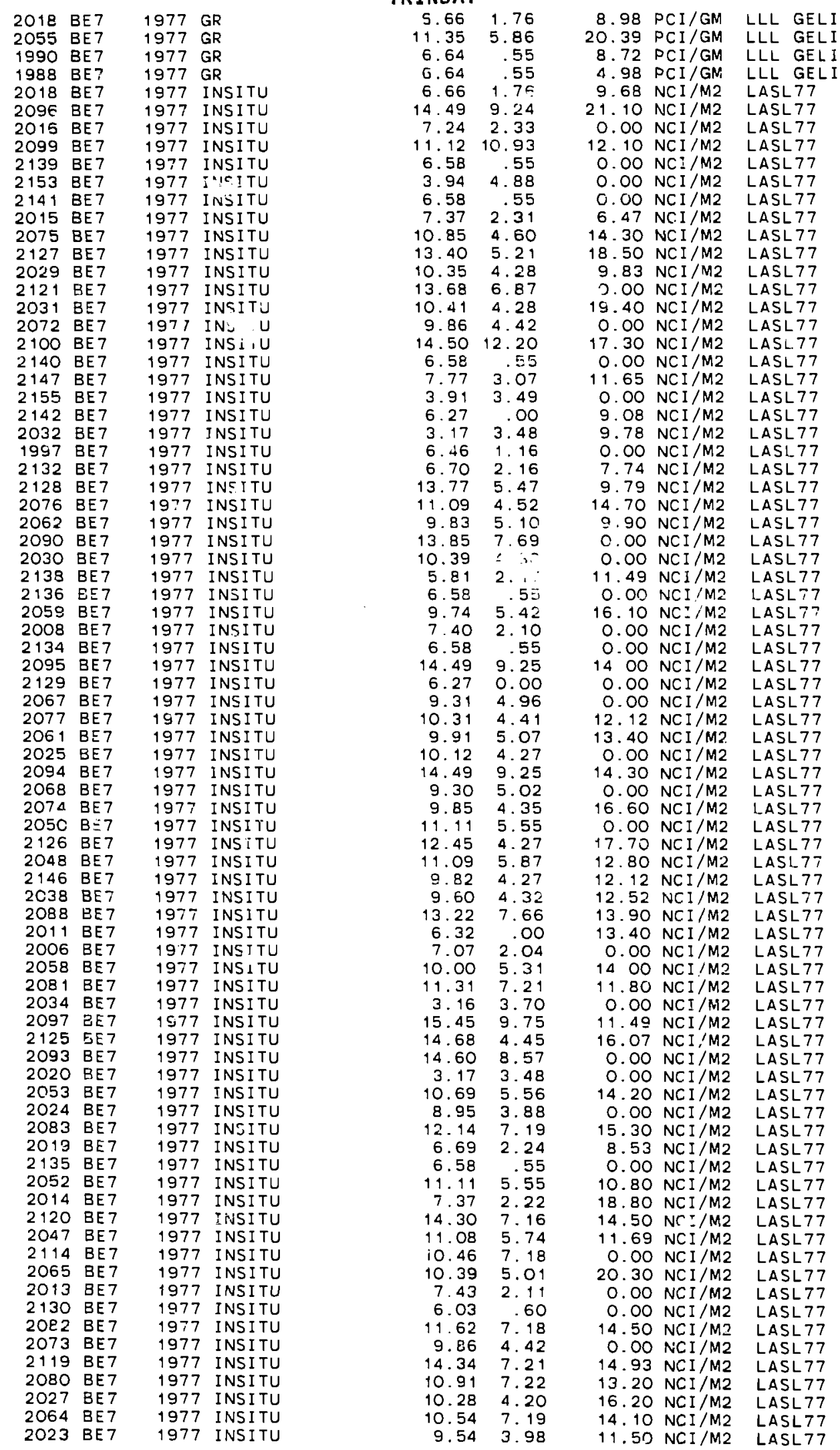




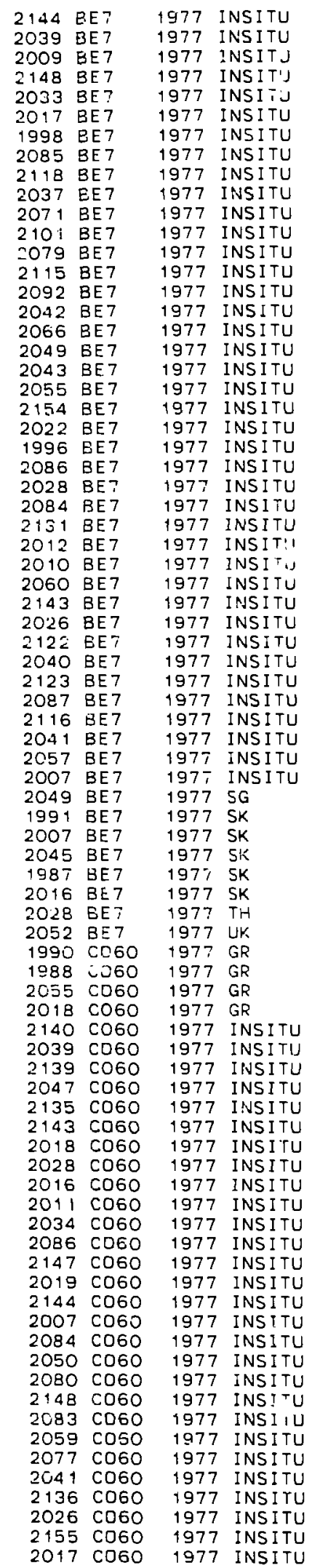

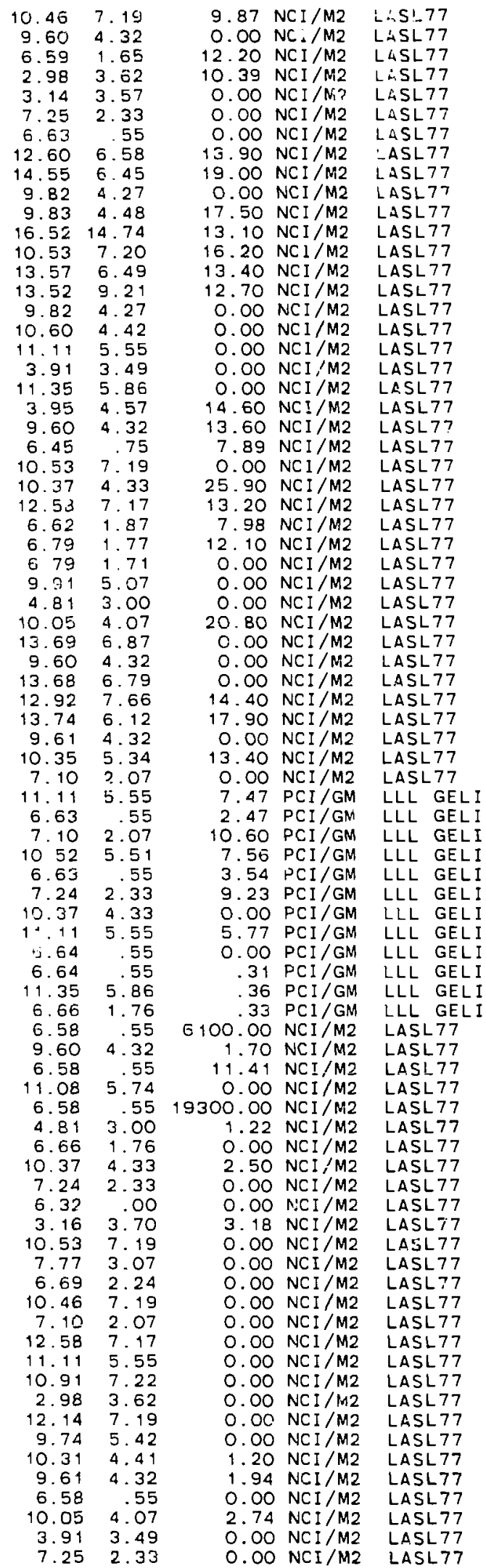




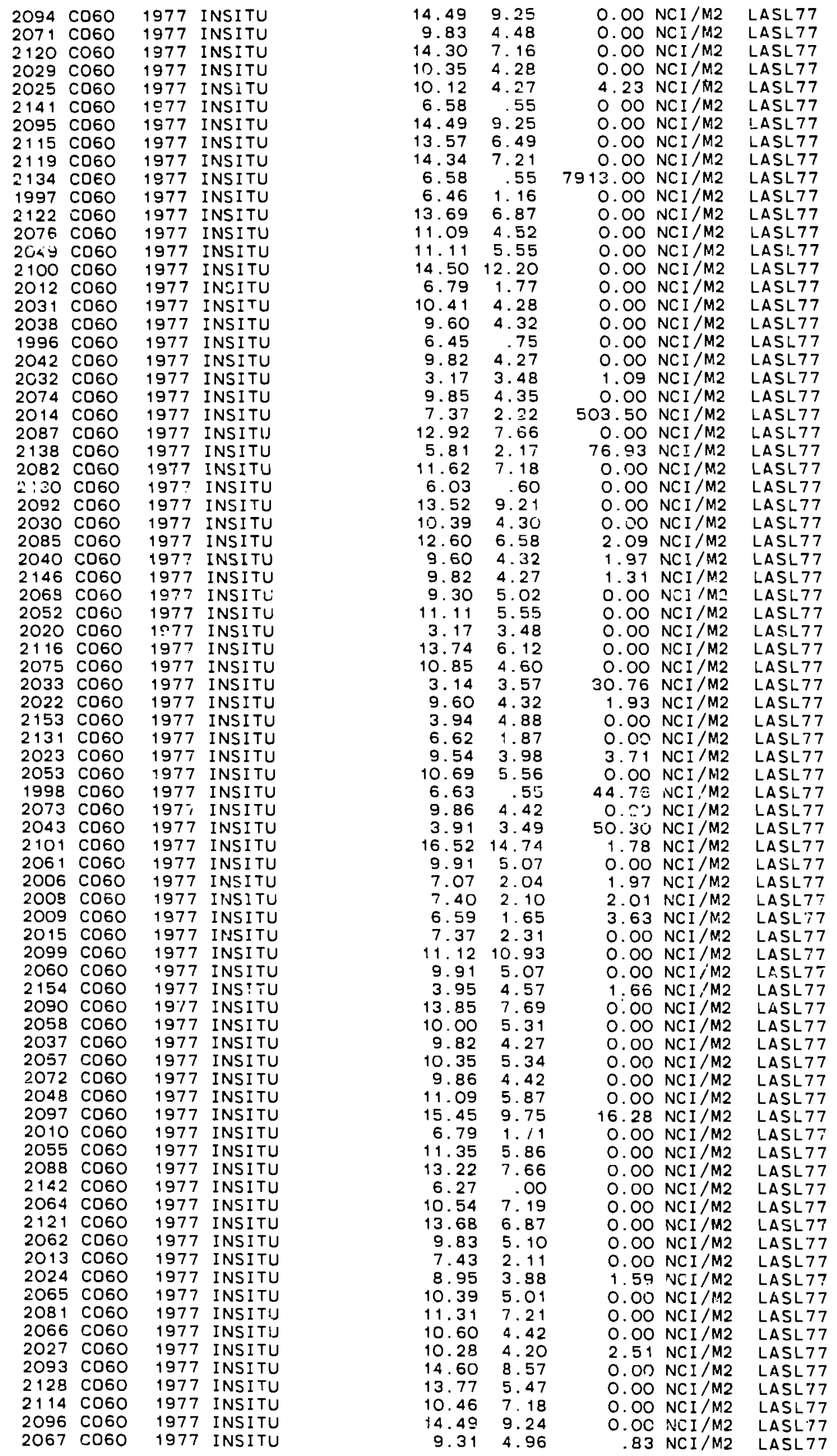




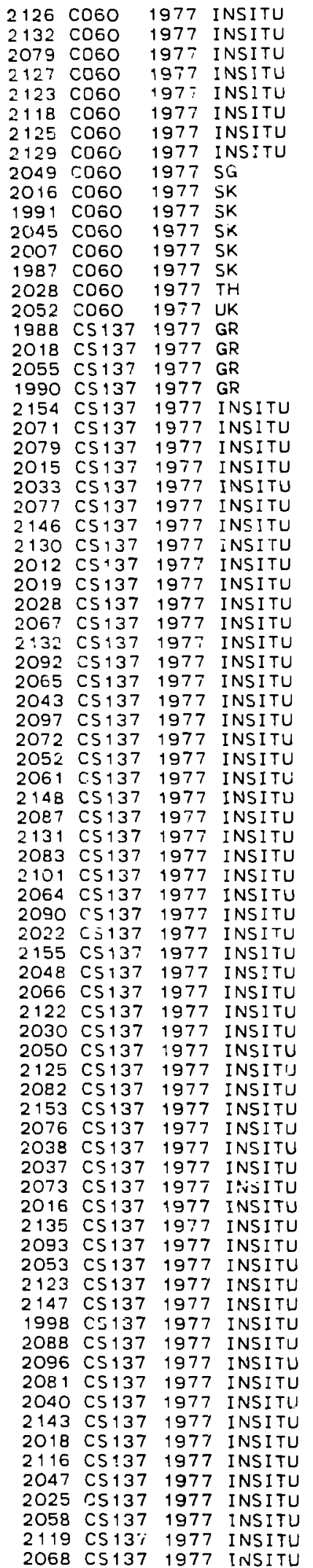

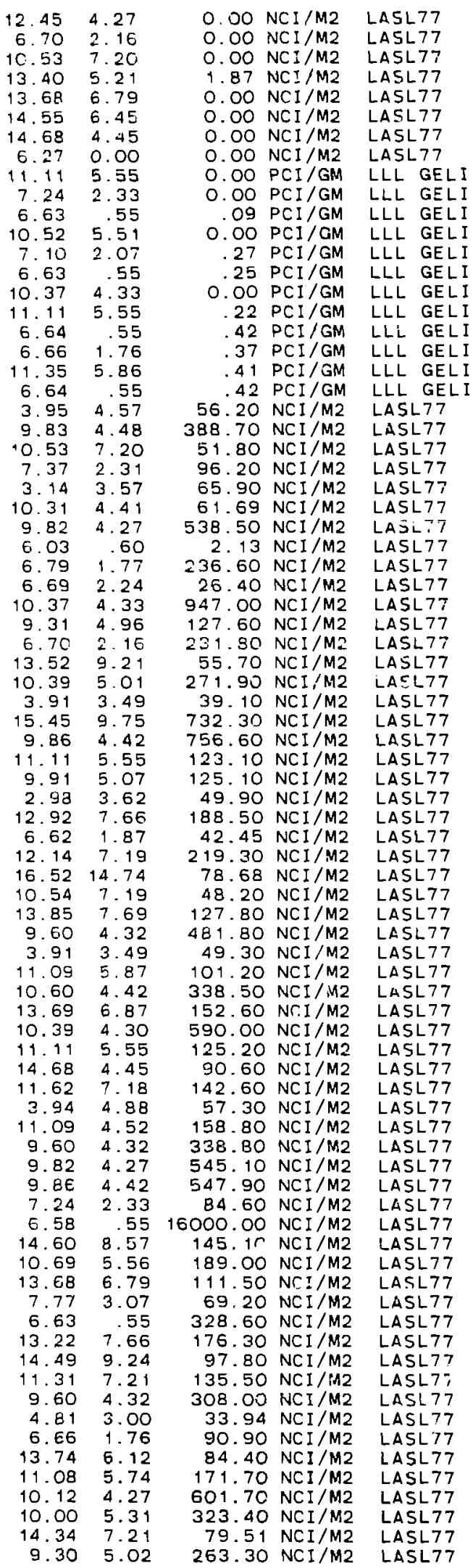




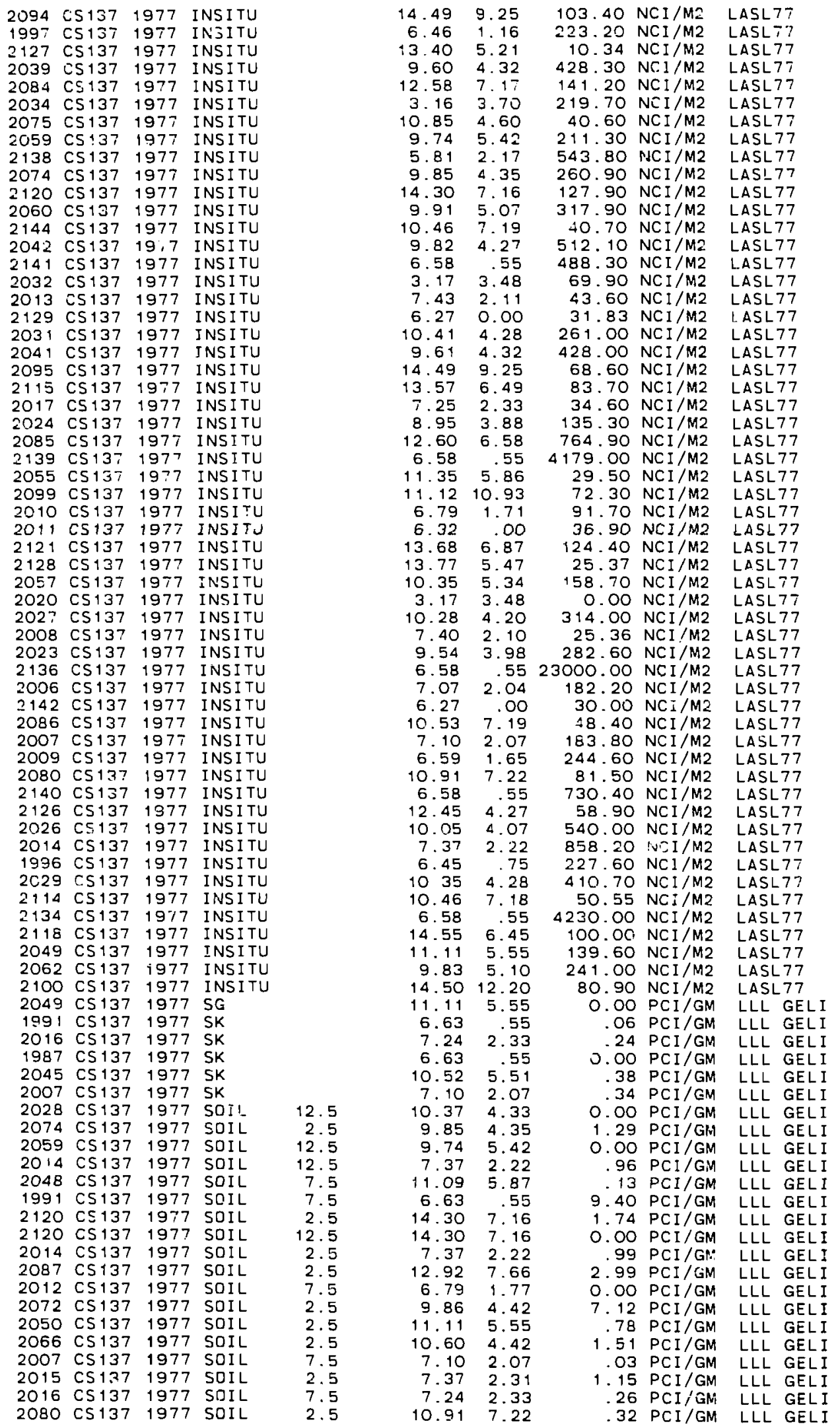




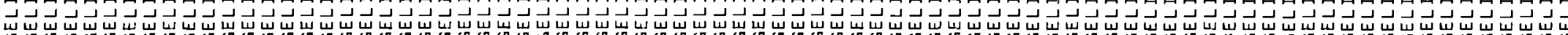

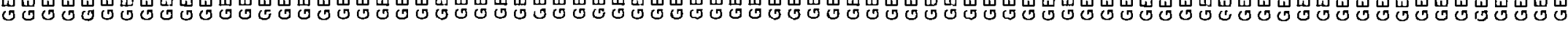

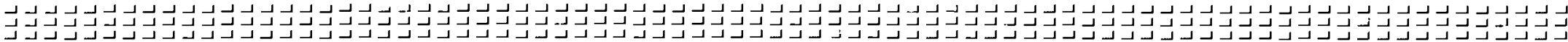

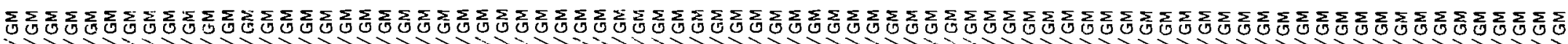

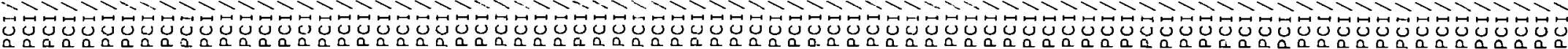

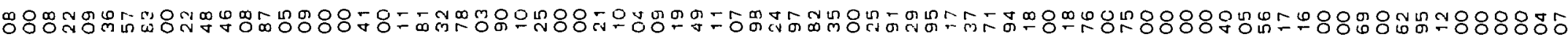
0 m 0
$\ln$ in 0 -
$\sin$
$6-$
on $-\overrightarrow{0}$
in $i$ i
०-0000응
-m+-0-0m
0000 in

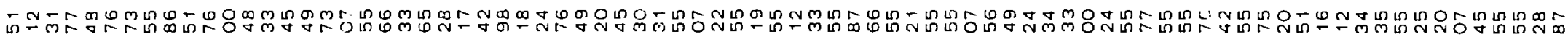

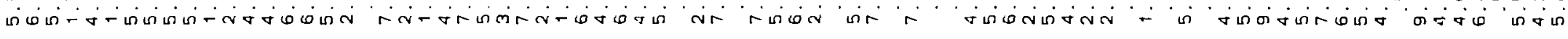

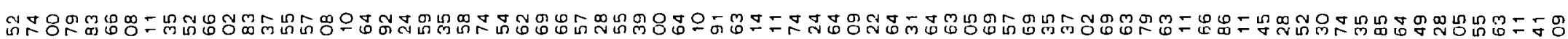

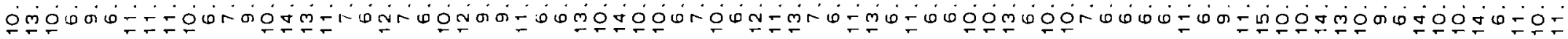

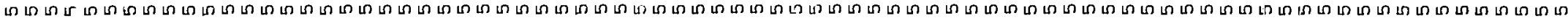

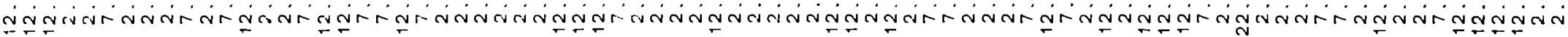

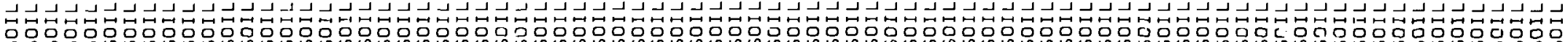

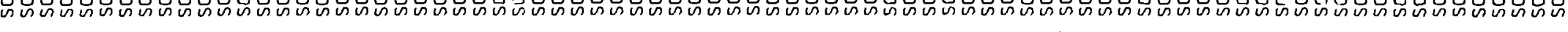

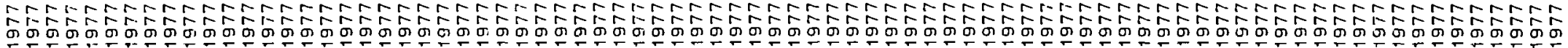

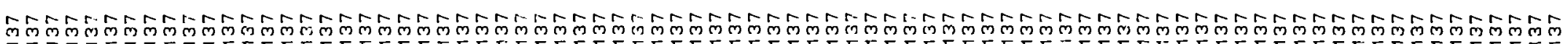

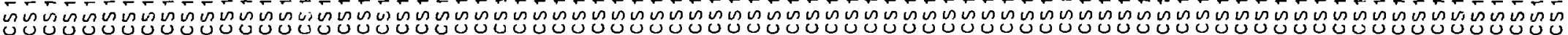

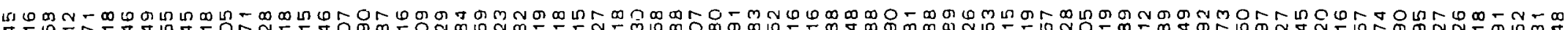

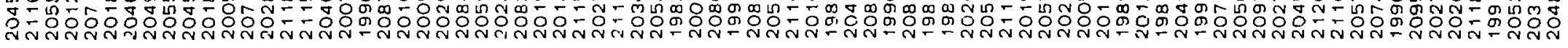




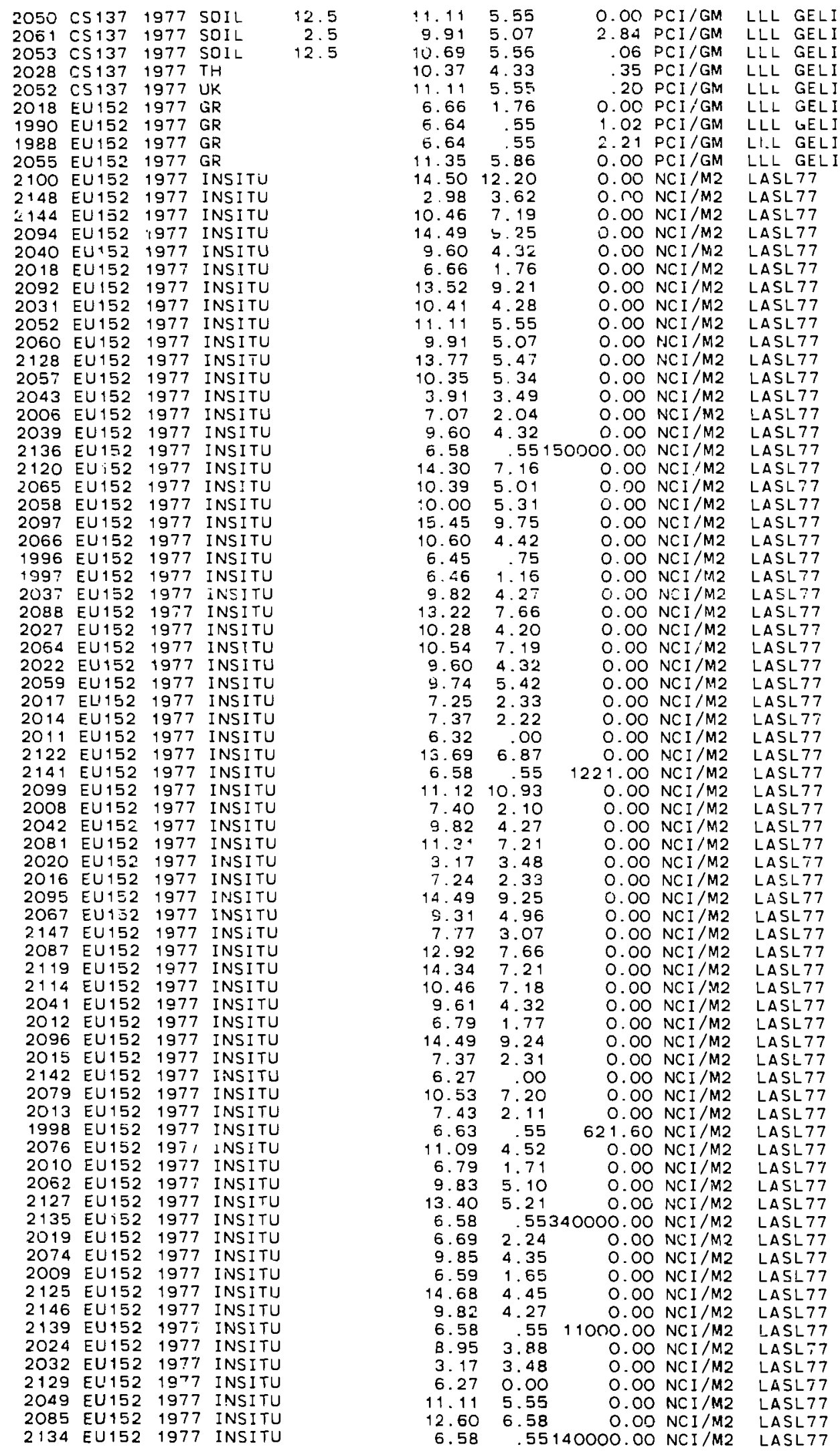




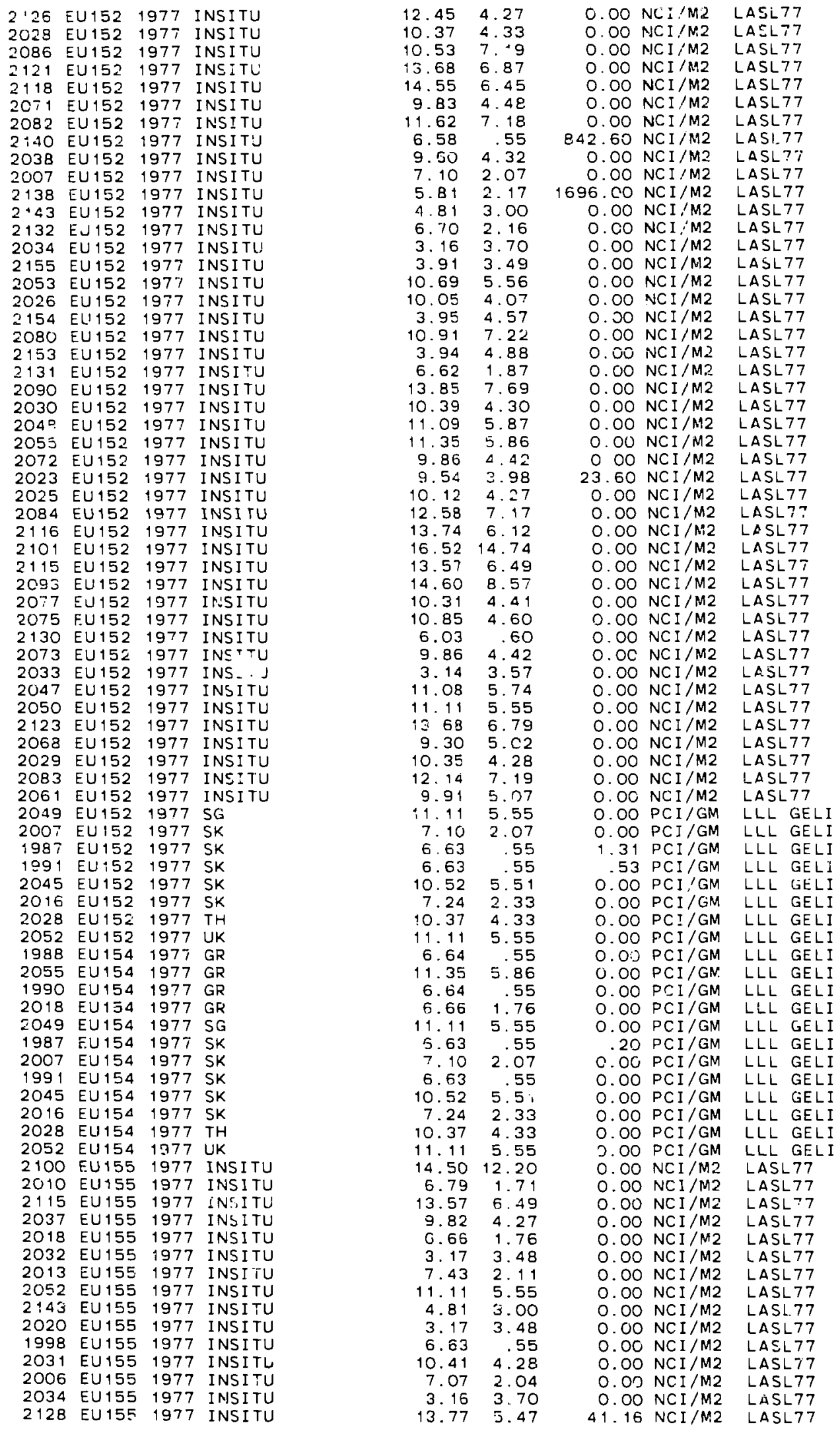


2012 EU155 1977 INSITU 2092 EU155 1977 INSITU 2072 EU 1551977 INSITU 2019 EU155 1977 INSITU 2067 EU155 1977 INSITU 2049 EU155 1977 INJITU $2: 32$ EU155 1977 INSIIU 2084 EU155 1977 INS:TU 2015 EU155 1977 INSITU 2141 EU155 197? INSITU 2059 EU155 1977 iNSITU 2050 EU:55 1977 INSITU 2080 EUi55 1977 INSITU 2085 EU155 1977 INSITU 2123 EU155 197? INSITU 2009 EU155 1977 INSITU 2064 EU 1551977 INSITU 2155 EU 1551977 INSITU 2118 EU 1551977 INSITU 2073 EU155 1977 INSITU 2016 EU155 1977 INSITU 2057 EU155 1977 INSITU 2042 EU155 1977 INSITU 2008 EU155 1977 INSITU 2086 EU 1551977 INSITU 2022 EU155 1977 INSITU 2027 EU155 1977 INSITU 2014 EU155 1977 INSITU 2127 EU155 1977 INSITU 2038 EU155 1977 INSITU 2122 EU155 1377 INSITU 2053 EU155 1977 INSITU

2065 EU15E 197\% INSITU 2071 EU155 1977 INSITU $2 C 47 \equiv U 155 \quad 1977$ INSITU 2:38 EU155 1977 INSITU 2033 EU155 1977 INSITU 2026 EU155 1977 INSITU 2153 EU155 1977 INSITU 2119 EU155 1977 INSITU 2048 EU155 1977 INSITU 1997 EU155 1977 INS ITU 2039 EU155 1977 INSITU 2061 EU155 1977 INSITU 2041 EU155 1977 INSITU 2075 EU155 1977 INSITI .OS4 EU155 1377 INS ITU 2024 EU155 1977 INSITU 1996 EUN155 1977 INSITL 2025 EU 1551977 INSITU 2060 EUi55 1977 INSITU 2077 EU 1551977 INSITL 2066 EU155 1977 INSITU 2007 EU 1551977 INSTTU 2090 EU155 1977 INS ITU 2028 EU 1551977 INSITU 2043 EU155 1977 INSITU 2062 EU155 1977 INSITU 2146 EU 1551977 INSITU 2140 EU 1551977 INSITU 2135 EU155 1977 INSITU 2058 EU155 1977 INSITU 2029 EU155 1977 INSITU 2079 EU155 1977 INSITU 2121 EU155 1977 INS ITU 2116 EU 1551977 INSITU 2125 EU155 :977 INSIII] 2017 EU155 1977 INSIT' 2129 EU155 1977 INSITU 2074 EU 1551977 INSITU 2083 EU155 1977 INSITU 2131 EU155 1977 INISITIJ 2134 EU155 1977 INSITU 2147 EU 1551977 IN!SITU 2097 EU155 1977 INSITU 2023 ELIS55 1977 INSITU 2088 EU 1551977 INSITL 2082 EU155 1977 INSITU 2139 EU155 1977 INSITU 2087 EU155 1977 INSITU

\begin{tabular}{|c|c|c|c|c|}
\hline $\begin{array}{r}6.79 \\
13.52\end{array}$ & $\begin{array}{l}1.77 \\
9.21\end{array}$ & $\begin{array}{r}81.60 \\
0.00\end{array}$ & $\begin{array}{l}\mathrm{NCI} / \mathrm{M} 2 \\
\mathrm{NCI} / \mathrm{M} 2\end{array}$ & $\begin{array}{l}\text { LASL } 77 \\
\text { LASL } 77\end{array}$ \\
\hline 9.86 & 4.42 & 0.00 & $\mathrm{NCI} / \mathrm{M} 2$ & LASL 77 \\
\hline 6.69 & 2.24 & 0.00 & $\mathrm{NCI} / \mathrm{M2}$ & $\angle A S L 77$ \\
\hline 9.31 & 4.96 & 0.00 & $\mathrm{NCI} / \mathrm{M} 2$ & LASL 77 \\
\hline 11. 11 & 5.55 & 0.00 & NCI / M2 & LASL $/ 7$ \\
\hline 6.70 & 2.16 & 0.00 & $\mathrm{NCI} / \mathrm{M} 2$ & LASL 77 \\
\hline 12.58 & 7.17 & 0.00 & $\mathrm{NCI} / \mathrm{M} 2$ & LASL 77 \\
\hline 7.37 & 2.31 & 0.00 & $\mathrm{NCI} / \mathrm{M} 2$ & LASL 77 \\
\hline 6.58 & .55 & 0.00 & NCI / M2 & LASL 77 \\
\hline & 5.42 & 0.00 & $\mathrm{NCI} / \mathrm{M} 2$ & LASL 77 \\
\hline 11.11 & 5.55 & 0.00 & $\mathrm{NCI} / \mathrm{M2}$ & LASL 77 \\
\hline 10.91 & 7.22 & 0.00 & $\mathrm{NCI} / \mathrm{M} 2$ & LASL 77 \\
\hline 12.60 & 6.58 & 0.00 & $\mathrm{NCI} / \mathrm{M} 2$ & LASL 77 \\
\hline 13.68 & 6.79 & 0.00 & $\mathrm{NCl} / \mathrm{M} 2$ & LASL 77 \\
\hline & 1.65 & 0.00 & NCI / M2 & LASL 77 \\
\hline & 7.19 & 0.00 & $\mathrm{NCI} / \mathrm{M} 2$ & LASL 77 \\
\hline 3. & 3.40 & 0.00 & $\mathrm{NCI} / \mathrm{M} 2$ & LASL 77 \\
\hline 14.55 & 6.45 & 0.00 & $\mathrm{NCI} / \mathrm{M} 2$ & SL 77 \\
\hline 9.86 & 4.42 & 0.00 & $\mathrm{NCI} / \mathrm{M} 2$ & $\llcorner A S\llcorner 77$ \\
\hline 7.24 & 2.33 & 0.00 & NCI / ME & $L A S\llcorner 77$ \\
\hline 10.35 & 5.34 & 0.00 & NCI / M2 & $S\llcorner 77$ \\
\hline & 4. 27 & 0.00 & $\mathrm{NCI} / \mathrm{M} 2$ & LASL 77 \\
\hline 7.40 & 2.10 & 0.00 & $\mathrm{NCI} / \mathrm{M} 2$ & LASL 7? \\
\hline 10.53 & 7.19 & 0.00 & $\mathrm{NCI} / \mathrm{M} 2$ & SL 77 \\
\hline 9.60 & 4. 32 & 0.00 & $\mathrm{NCI} / \mathrm{M} 2$ & $\llcorner\triangle S\llcorner 77$ \\
\hline 10.28 & 4. 20 & 0.00 & $\mathrm{NCI} / \mathrm{M} 2$ & LASL 77 \\
\hline & 2.22 & 0.00 & NCI / M2 & $\$ 1.77$ \\
\hline 13.40 & 5.21 & 0.00 & $\mathrm{NCI} / \mathrm{M} 2$ & LASL 77 \\
\hline & 4. 32 & 0.00 & $\mathrm{NCI} / \mathrm{M} 2$ & LASL 77 \\
\hline 13.69 & 6.87 & 0.00 & $\mathrm{NCI} / \mathrm{M2}$ & SL77 \\
\hline 10. & 5.56 & 0.00 & NCI $/$ M2 & LASL 77 \\
\hline 10. & 5.01 & 0.00 & $\mathrm{NCl} / \mathrm{M} 2$ & LASL 77 \\
\hline 9.83 & 4.48 & 0.00 & $\mathrm{NCI} / \mathrm{M} 2$ & LASL 77 \\
\hline 11. & 5.74 & 0.00 & $\mathrm{NCl} / \mathrm{M} 2$ & LASL 77 \\
\hline & 2.17 & 0.00 & $\mathrm{NCI} / \mathrm{M} 2$ & LASL 77 \\
\hline 14 & 3.57 & 0.00 & $\mathrm{NCI} / \mathrm{M} 2$ & LASL 77 \\
\hline 05 & 4.07 & 55.10 & NCI / M2 & LASL 77 \\
\hline & 4.88 & 0.00 & $\mathrm{NCI} / \mathrm{M} 2$ & L 77 \\
\hline 14. & 7.21 & 0.00 & $\mathrm{NCl} / \mathrm{M} 2$ & LASL 77 \\
\hline 09 & 5.87 & 0.00 & $\mathrm{NCI} / \mathrm{M} 2$ & $L 77$ \\
\hline 46 & 1.16 & 0.00 & $\mathrm{NCI} / \mathrm{M} 2$ & L 77 \\
\hline ธิ & 4.32 & 0.00 & $\mathrm{NCI} / \mathrm{M} 2$ & LASL77 \\
\hline 91 & 5.07 & 0.00 & $\mathrm{NCI} / \mathrm{M} 2$ & $L 77$ \\
\hline 9.61 & 4.32 & $c .00$ & $\mathrm{NCI} / \mathrm{M} 2$ & L77 7 \\
\hline 10.85 & 4.60 & 2.00 & $\mathrm{NCI} / \mathrm{M}_{2}$ & LASI 77 \\
\hline 49 & 9.25 & $0 . j 0$ & $\mathrm{NCI} / \mathrm{M} 2$ & L 77 \\
\hline 95 & $3.8 \varepsilon$ & 0.00 & $\mathrm{NCI} / \mathrm{M} 2$ & $\mathrm{~L}: 7$ \\
\hline 45 & 75 & 0.00 & $\mathrm{NCI} / \mathrm{Mi} 2$ & LASL 77 \\
\hline 12 & 4.27 & 0.00 & $\mathrm{NCI} / \mathrm{M} 2$ & 477 \\
\hline 91 & 5.07 & 0.00 & $\mathrm{NCI} / \mathrm{M} 2$ & LASL 77 \\
\hline 10.31 & 4.41 & 0.00 & $\mathrm{NCI} / \mathrm{M} 2$ & LASL 77 \\
\hline 10.60 & 4.42 & & $\mathrm{NCI} / \mathrm{M2}$ & $\llcorner 77$ \\
\hline 10 & 2.07 & 0.00 & $\mathrm{NCI} / \mathrm{M} 2$ & LASL 77 \\
\hline 85 & 7.69 & 0.00 & $\mathrm{NCI} / \mathrm{M} 2$ & L 77 \\
\hline 10.37 & & 86.00 & NCI / M2 & L77 \\
\hline 3.91 & 3.49 & 0.00 & NCI / M2 & LASL 77 \\
\hline 9.83 & 5.10 & 0.00 & $\mathrm{NC} 1 / \mathrm{M}_{2}$ & LASL 77 \\
\hline 82 & 4.27 & 0.00 & $\mathrm{NCI} / \mathrm{M} 2$ & L 477 \\
\hline 58 & .55 & 0.00 & $\mathrm{NCI} / \mathrm{M} 2$ & SL77 \\
\hline 6.58 & 55 & & $\mathrm{NCI} / \mathrm{M} 2$ & $5\llcorner 77$ \\
\hline 10.00 & 5.31 & 0.00 & $\mathrm{NCI} / \mathrm{M} 2$ & L 77 \\
\hline 35 & 4.28 & 0.00 & $\mathrm{NCI} / \mathrm{M} 2$ & $\triangle S L 77$ \\
\hline 10 & 7.20 & & $\mathrm{NCI} / \mathrm{M} 2$ & 477 \\
\hline 68 & 6.87 & 0.00 & $\mathrm{NCI} / \mathrm{M} 2$ & L 77 \\
\hline & 6.12 & & $\mathrm{NCI} / \mathrm{M}_{2}$ & L 77 \\
\hline 14.68 & & & $\mathrm{NCI} / \mathrm{M} 2$ & L77 \\
\hline 25 & 2.33 & 0.00 & $\mathrm{NCI} / \mathrm{M} 2$ & L77 \\
\hline 27 & 0.00 & 0.00 & $\mathrm{NCI} / \mathrm{M} 2$ & L77 \\
\hline 9.35 & & & $\mathrm{NCI} / \mathrm{M} 2$ & L77 \\
\hline 12.14 & 7.19 & 0.00 & NCI / M2 & SL 77 \\
\hline 62 & 1.87 & 0.00 & $\mathrm{NCI} / \mathrm{M} 2$ & LASL 77 \\
\hline 6.58 & .55 & & NCI /M2 & LASL 77 \\
\hline 7.77 & 3.07 & 0.30 & iฟC I / M2 & LASL 77 \\
\hline 15.45 & & 0.00 & NCI / M2 & LASL 77 \\
\hline 9.54 & 3.98 & 0.00 & $\mathrm{NCI} / \mathrm{M} 2$ & LASL 77 \\
\hline 13.22 & 7.66 & 0.00 & $\mathrm{NCI} / \mathrm{M} 2$ & LASL 77 \\
\hline 11.62 & 7.18 & 0.00 & $\mathrm{NCI} / \mathrm{M} 2$ & LASL 77 \\
\hline 6.58 & & 6.0 & NCI / M2 & LASL 77 \\
\hline 12 & 756 & 0.00 & $\mathrm{NCI} / \mathrm{M} 2$ & LASL 77 \\
\hline
\end{tabular}




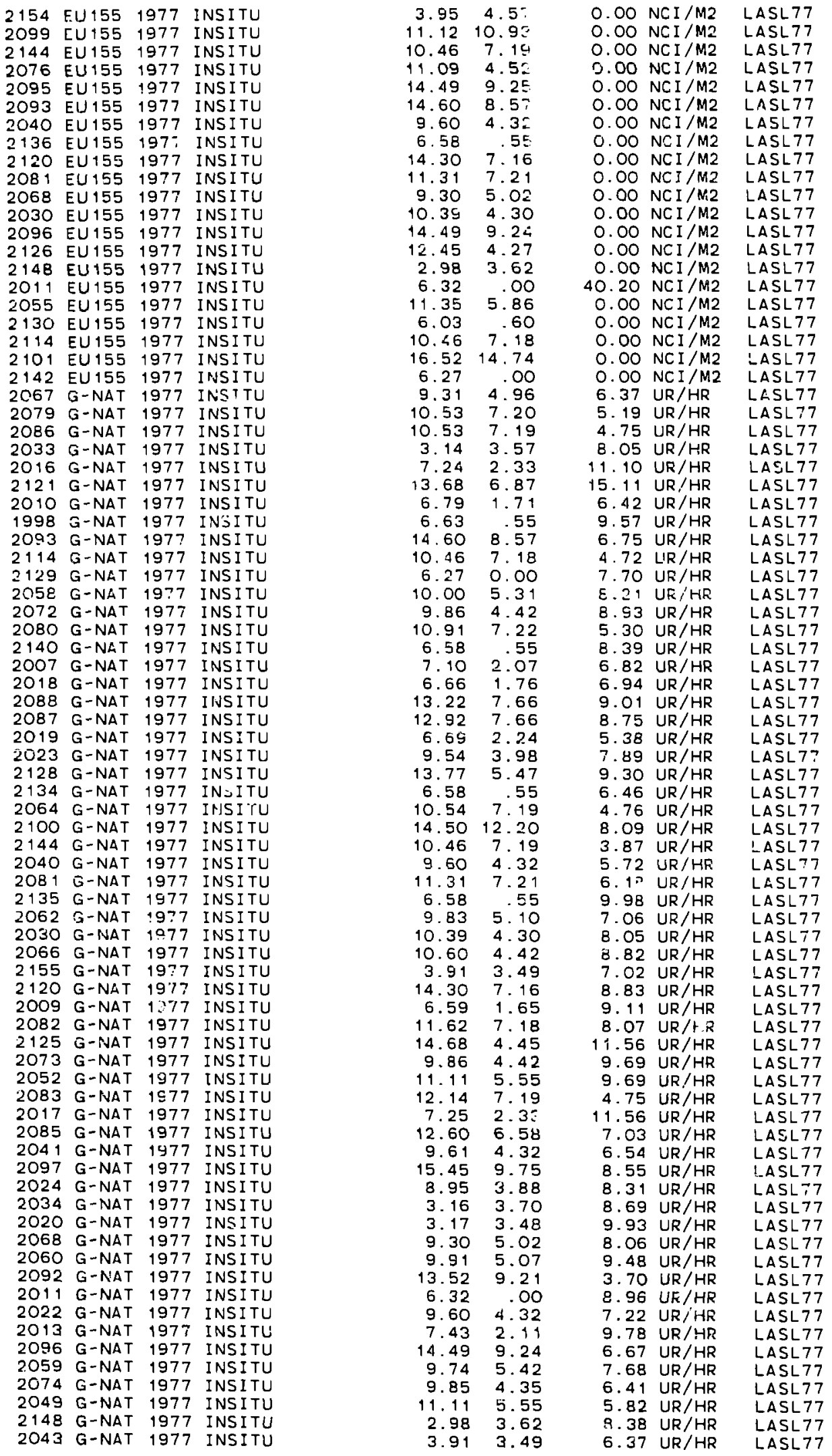




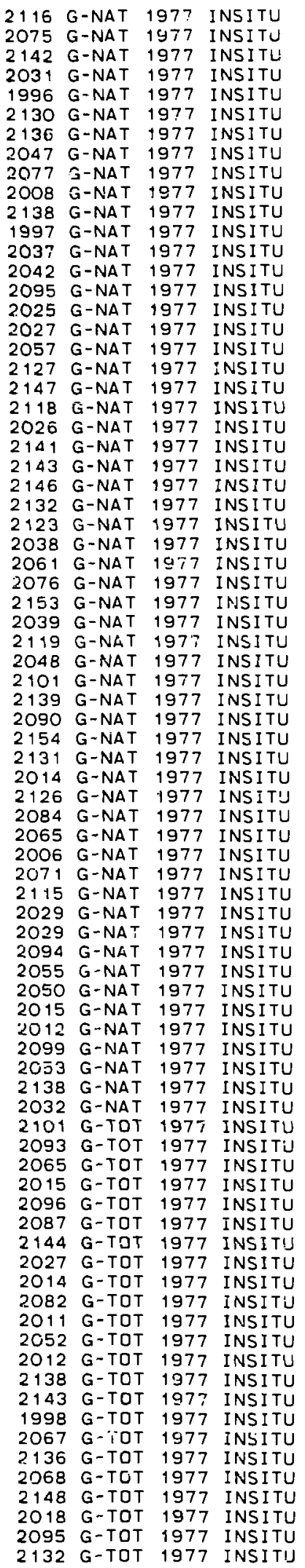

\begin{tabular}{|c|c|c|c|c|}
\hline & & & & \\
\hline 13.74 & 6. 12 & 9.16 & $U R / H R$ & LASL 77 \\
\hline $\begin{array}{r}10.85 \\
6.27\end{array}$ & 4.60 & 6.05 & UR/HR & LASL 77 \\
\hline 10.41 & $\begin{array}{l}.00 \\
4.28\end{array}$ & 7.68 & UR/HR & LASL 77 \\
\hline 6.45 & $\begin{array}{r}4.28 \\
.75\end{array}$ & 6.07 & UR / HR & LASL 77 \\
\hline 6.03 & .60 & $\begin{array}{c}9.13 \\
9.16\end{array}$ & $\begin{array}{l}\text { UR/HR } \\
\text { UR/HR }\end{array}$ & LAS: 77 \\
\hline 6.58 & 55 & 5.471 & UR/HR & LASL 77 \\
\hline 11.08 & 5.74 & $7.17 \mathrm{~L}$ & UR/HR & LASL 77 \\
\hline 10.31 & 4.41 & 7.29 & $\mathrm{UR} / \mathrm{HR}$ & LASL 77 \\
\hline 7.40 & 2.10 & 15.99 & UR i HR & LASL 77 \\
\hline 5.81 & 2.17 & 1.55 & UR / HR & LASL 77 \\
\hline 6.46 & 1.16 & 4.56 & UR/HR & LASL 77 \\
\hline 9.82 & 4.27 & 9.27 & UR/HR & LASL77 \\
\hline 9.82 & 4. 27 & 9.69 & UR/HR & LASL 77 \\
\hline 14.49 & 9.25 & 5.83 & UR/HR & LASL 77 \\
\hline 10. 12 & 4. 27 & 6.22 & $\mathrm{UR} / \mathrm{HR}$ & LASL 77 \\
\hline 10. 28 & 4. 20 & 4.36 & UR/HR & LASL 77 \\
\hline 10.35 & 5.34 & 7.36 & UR/HR & LASL 77 \\
\hline 13.40 & 5.21 & 7.87 & UR/HR & LASL 77 \\
\hline $\begin{array}{r}7.77 \\
.5\end{array}$ & 3.07 & 5.42 & $\begin{array}{l}U R / H R \\
U D\end{array}$ & LAS -77 \\
\hline 14.55 & 6.45 & 8.82 & UR/HR & LASL 77 \\
\hline 10.05 & $\begin{array}{r}4.07 \\
55\end{array}$ & 8.56 & UR/HR & LASL 77 \\
\hline 6.58 & .55 & 8.74 & UR/HR & LM SL 577 \\
\hline 4.81 & 3.00 & 5.72 & UR/HR & LASL 77 \\
\hline 9.82 & 4.27 & 3.46 & UR/HR & LASL 77 \\
\hline 6.70 & 2.16 & 4.72 & UR/HR & LASL 77 \\
\hline 13.68 & 6.79 & 12.60 & UR/HR & LASL 77 \\
\hline 9.60 & $\begin{array}{l}4.32 \\
5.07\end{array}$ & 5.73 & UR/HR & LASL 77 \\
\hline 9.91 & 5.07 & 9.96 & U.../HR & LASL 77 \\
\hline 11.09 & 4.52 & 3.85 & UR / HR & LASL 77 \\
\hline $\begin{array}{l}3.94 \\
9.60\end{array}$ & $\begin{array}{l}4.88 \\
4.32\end{array}$ & 5.50 & $\begin{array}{l}\text { UR / HR } \\
\text { UR/HR }\end{array}$ & LASL77 \\
\hline 14.34 & $\begin{array}{l}4.32 \\
7.21\end{array}$ & $\begin{array}{l}3.98 \\
6.71\end{array}$ & UR/HR & $\begin{array}{l}\text { LASL } 77 \\
\text { LASL } 77\end{array}$ \\
\hline 11.09 & 5.87 & 6.97 & UR/HR & LASL 77 \\
\hline 16.52 & 14.74 & 6.87 & UR/HR & LASL 77 \\
\hline 5.58 & .55 & 8. 14 & $\mathrm{UR} / \mathrm{HR}$ & LASL 77 \\
\hline 13.85 & 7.69 & 14.08 & UR / HR & LAS 77 \\
\hline 3.95 & 4.57 & 4.79 & UR/HR & LASL 77 \\
\hline 6.62 & 1.87 & 6.77 & UR/HR & LASL 77 \\
\hline 7.37 & 2.22 & 11.02 & UR/HR & LASL 77 \\
\hline 12.45 & 4.27 & 7.09 & UR/HR & LASL 77 \\
\hline 12.58 & 7.17 & 8.14 & UR/HR & LASL 77 \\
\hline 10.39 & 5.01 & 5.96 & UR/HR & LASL 77 \\
\hline 7.07 & 2.04 & 5.40 & UR/HR & LASL 77 \\
\hline 9.83 & 4.48 & 7.56 & UR/HR & LASL 77 \\
\hline 13.57 & 6.49 & 8.65 & UR / HR & LASL 77 \\
\hline 10.35 & 4.28 & 7.60 & UR/HR & LASL 77 \\
\hline 10.35 & 4.28 & 8.10 & UR/HR & LASL. 77 \\
\hline 14.49 & 9.25 & 01 & UR / HR & LASL 77 \\
\hline 11.35 & 5.86 & 7.03 & UR/HR & LASL 77 \\
\hline 11.11 & 5.55 & 5.64 & UR/HR & LASL 77 \\
\hline 7.37 & 2.31 & 2.87 & UR/HR & LASL 77 \\
\hline 6.79 & 1.77 & 9.47 & UR/HR & LASL 77 \\
\hline 1112 & 10.93 & 3.96 & UR/HR & LASL77 \\
\hline 10.69 & 5.56 & 4.46 & UR/HR & LASL 77 \\
\hline 5.81 & 2.17 & 8.15 & UR/HR & LASL 77 \\
\hline 3.17 & 3.48 & 8.79 & UR/HR & LASL 77 \\
\hline 16.52 & 14.74 & 7.34 & UR/HR & LASL 77 \\
\hline 14.60 & 8.57 & 7.54 & UR/HR & LASL 77 \\
\hline 10.39 & 5.01 & 7.01 & UR/HR & LASL 77 \\
\hline 7.37 & 2.31 & 3.29 & UR/HR & LASL 77 \\
\hline 14.49 & 9.24 & 7.25 & UR/HR & LASL 77 \\
\hline 12.92 & 7.06 & 9.75 & UR/HR & LASL 77 \\
\hline 10.46 & 7.19 & 4. 12 & UR/HR & LASL 77 \\
\hline 10.28 & 4.20 & 5.67 & UR/HR & LASL 77 \\
\hline 7.37 & 2.22 & 11.47 & UR/HR & LASL.77 \\
\hline 11.62 & 7.18 & 8.89 & UR/HR & LASL 77 \\
\hline 6.32 & .00 & 9.28 & UR/HR & LASL 77 \\
\hline 11.11 & 5.55 & 10.23 & $\mathrm{UR} / \mathrm{HR}$ & LASL 77 \\
\hline 6.79 & 1.77 & 10.46 & UR/HR & LASL 77 \\
\hline 5.81 & 2. 17 & 1.79 & UR/HR & LASL 77 \\
\hline 4.81 & 3.00 & 5.89 & $\therefore R / H R$ & LASL 77 \\
\hline 6.63 & .55 & 10.60 & $\mathrm{UR} / \mathrm{HR}$ & LASL 77 \\
\hline 9.31 & 4.96 & 7.04 & $\mathrm{UR} / \mathrm{HR}$ & LASL 77 \\
\hline 6.58 & .55 & 174.70 & UR/HR & LASL 77 \\
\hline 9.30 & 5.02 & 9.14 & UR/HR & LASL 77 \\
\hline 2.98 & 3.62 & 8.62 & UR/HR & LASL 77 \\
\hline 5.66 & 1.76 & 7.36 & UR/HR & LASL 77 \\
\hline 14.49 & 9.25 & 6.26 & UR/HR & LASL 77 \\
\hline 6.70 & 2.16 & 4.91 & UR/HR & LASL 77 \\
\hline
\end{tabular}




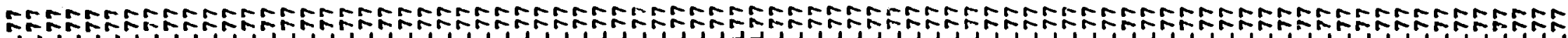

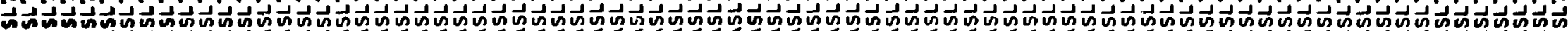

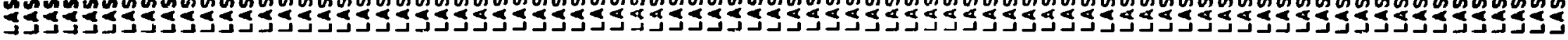

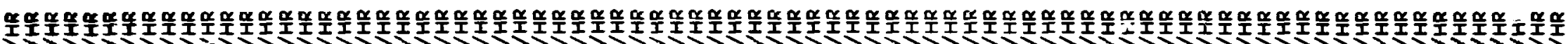

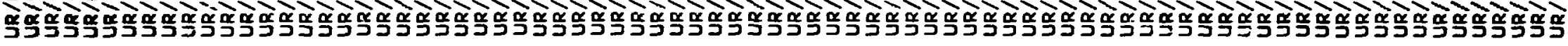

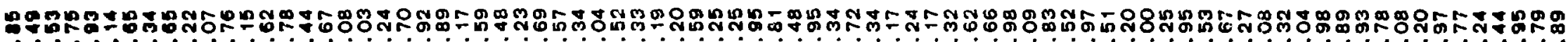

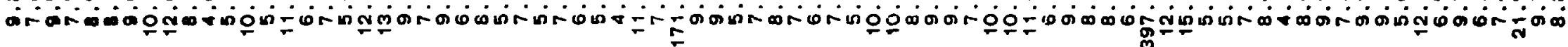

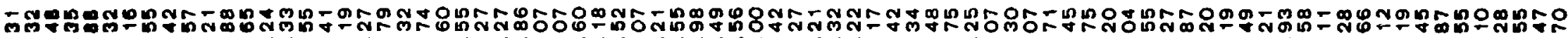

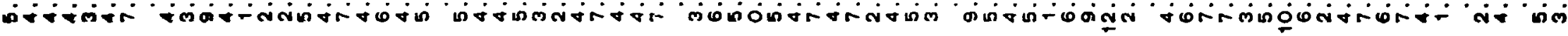

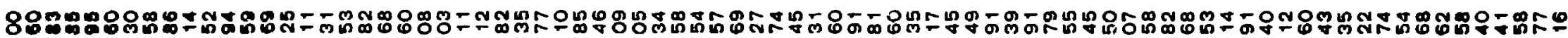

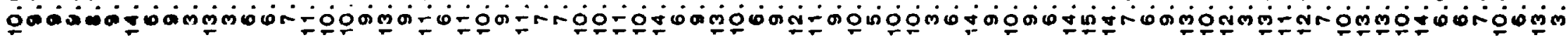

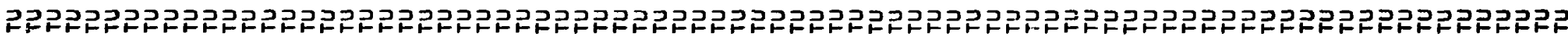

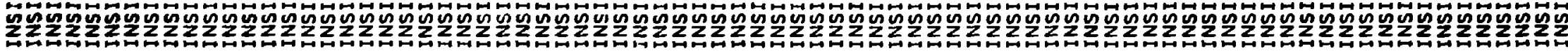

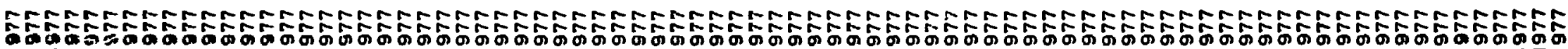

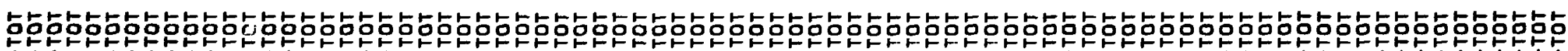

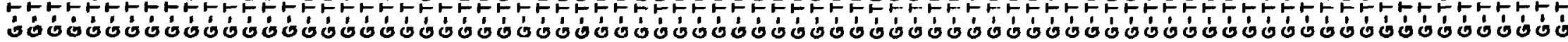

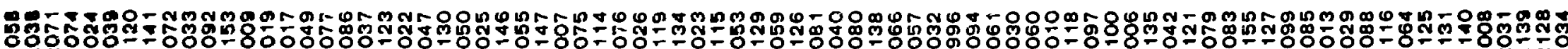

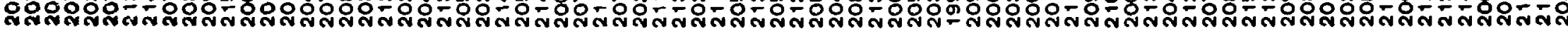




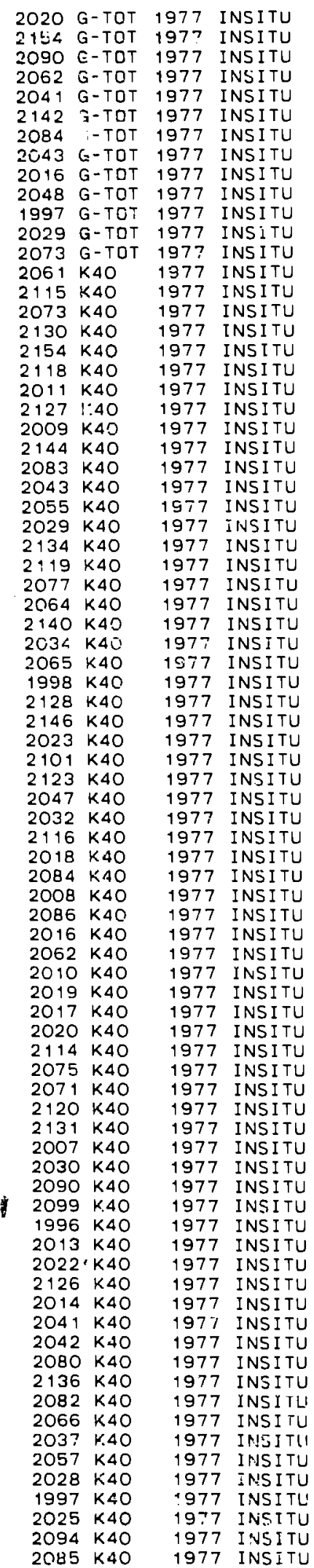

\begin{tabular}{|c|c|c|c|c|}
\hline $\begin{array}{l}3.17 \\
3.95\end{array}$ & $\begin{array}{l}3.48 \\
4.57\end{array}$ & $\begin{array}{l}9.95 \\
5.16\end{array}$ & $\begin{array}{l}\text { UR/HR } \\
\text { UR/HR }\end{array}$ & $\begin{array}{l}\text { LASL } 77 \\
\text { LASL } 77\end{array}$ \\
\hline 13.85 & 7.69 & 14.68 & UR $/ \mathrm{HR}$ & LASL 77 \\
\hline 9.83 & 5. 10 & 8.25 & $\mathrm{UR} / \mathrm{HR}$ & LASL 77 \\
\hline 9.61 & 4. 32 & e. 74 & UR/HR & LASL 77 \\
\hline 27 & .00 & 7.90 & $U R / H R$ & LASL 77 \\
\hline 12.58 & 7.17 & 8.89 & UR / HR & LASL 77 \\
\hline 3.91 & 3.49 & 6.42 & $\mathrm{UR} / \mathrm{HR}$ & LASL 77 \\
\hline 7.24 & 2.33 & 11.50 & UR/HR & LASL 77 \\
\hline 11.09 & 5.87 & 755 & UR/HR & LASL 77 \\
\hline 6.46 & 1.16 & 4.69 & UR/HR & LASL 77 \\
\hline 10.35 & 4.28 & 11.72 & $U R / H R$ & LASL 77 \\
\hline 9.86 & 4.42 & 12.42 & UR/HR & LASL 77 \\
\hline 9.91 & 5.07 & 24.10 & $\mathrm{PCI} / \mathrm{GM}$ & LASL 77 \\
\hline 13.57 & 6.49 & 21.50 & PCI / GM & LASL 77 \\
\hline 9.86 & 4.42 & 22.60 & $P C i / G M$ & LASL 77 \\
\hline 6.03 & .60 & 18.50 & $\mathrm{PCI} / \mathrm{GM}$ & LASL 77 \\
\hline 3.95 & 4.57 & 11.79 & $\mathrm{PCI} / \mathrm{GM}$ & LASL 77 \\
\hline 14.55 & 6.45 & 19.40 & $\mathrm{PCI} / \mathrm{GM}$ & LASL 77 \\
\hline 6.32 & .00 & 24.30 & $P C I / G M$ & LAS1.77 \\
\hline 13.40 & 5.21 & 15.90 & $\mathrm{PCI} / \mathrm{GM}$ & LASL 77 \\
\hline 6.59 & 1.65 & 16.65 & $\mathrm{PCI} / \mathrm{GM}$ & LASL 77 \\
\hline 10.46 & 7.19 & 12.40 & $\mathrm{PCI} / \mathrm{GM}$ & LASL 77 \\
\hline 12.14 & 7.19 & 9.90 & $\mathrm{PCI} / \mathrm{GM}$ & LASL $7 \bar{T}$ \\
\hline 3.91 & 3.49 & 14.29 & $\mathrm{PCI} / \mathrm{GM}$ & LASL 77 \\
\hline 11.35 & 5.86 & 16.50 & $\mathrm{PCI} / \mathrm{GM}$ & LASL 77 \\
\hline 10.35 & 4. 28 & 18.57 & $\mathrm{PCI} / \mathrm{GM}$ & LASL 77 \\
\hline 6.58 & .55 & 14.68 & $\mathrm{PCI} / \mathrm{GM}$ & LASL 77 \\
\hline 14.34 & 7.21 & 17.32 & $P C I / G M$ & LASL 77 \\
\hline 10.31 & 4.41 & 17.08 & $\mathrm{PCI} / \mathrm{GM}$ & LASL 77 \\
\hline 10.54 & 7.19 & 14.56 & $\mathrm{PCI} / \mathrm{GM}$ & LASL 77 \\
\hline 6.58 & .55 & 23.90 & $\mathrm{PCI} / \mathrm{GM}$ & LASI. 77 \\
\hline 3. 16 & 3.70 & 19. $1 E$ & FCI/GM & LASL 77 \\
\hline 10.39 & 5.01 & 13.80 & PCI / GM & LASL 77 \\
\hline 6.63 & .55 & 29.90 & $\mathrm{PCI} / \mathrm{GM}$ & LASL 77 \\
\hline 13.77 & 5.47 & $18 \cdot 30$ & $\mathrm{PCI} / \mathrm{GM}$ & LASL 77 \\
\hline 9.82 & 4.27 & 6.41 & $\mathrm{PCI} / \mathrm{GM}$ & LASL 77 \\
\hline 9.54 & 3.98 & 17.30 & $\mathrm{PCI} / \mathrm{GM}$ & LASL 77 \\
\hline 16.52 & 14.74 & 14.90 & $\mathrm{PCI} / \mathrm{GM}$ & LASL 77 \\
\hline 13.68 & 6.79 & 28.40 & PC.I/GM & LASL77 \\
\hline 11.08 & 5.74 & 12.89 & $\mathrm{PCI} / \mathrm{GM}$ & LASL 77 \\
\hline 3.17 & 3.48 & 17.10 & PCI / GM & LAS $\angle 77$ \\
\hline 13.74 & 6.12 & 19.60 & $\mathrm{PCI} / \mathrm{GM}$ & LASL77 \\
\hline 6.66 & 1.76 & 20.40 & PCI / GM & LASL 77 \\
\hline 12.58 & 7.17 & 18.30 & PCI / GM & LASL 77 \\
\hline 7.40 & 2.10 & 13.28 & $\mathrm{PCI} / \mathrm{GM}$ & LASL 77 \\
\hline 10.53 & 7.19 & 15.01 & $\mathrm{PCI} / \mathrm{GM}$ & LASL 77 \\
\hline 7.24 & 2.33 & 30.94 & $\mathrm{PC} \mathrm{I} / \mathrm{GM}$ & LASL 77 \\
\hline 9.83 & 5.10 & $1 E .90$ & $\mathrm{PCI} / \mathrm{GM}$ & LASL 77 \\
\hline 6.79 & 1.71 & 18.10 & $P C_{j} / G M$ & LASL 77 \\
\hline 6.69 & 2.24 & 16. 11 & $\mathrm{PCI} / \mathrm{GM}$ & LASL 77 \\
\hline 7.25 & 2.33 & 26.60 & $\mathrm{PCI} / \mathrm{GM}$ & LASL 77 \\
\hline 3.17 & 3.48 & 19.48 & $\mathrm{PCI} / \mathrm{GM}$ & LASL 77 \\
\hline 10.46 & 7.18 & 14.48 & $\mathrm{PCI} / \mathrm{GM}$ & LASL 77 \\
\hline 10.85 & 4.60 & 14.80 & $\mathrm{PCI} / \mathrm{GM}$ & LASL 77 \\
\hline 9.83 & 4.48 & 16.20 & $\mathrm{PCI} / \mathrm{GM}$ & LAS $\angle 77$ \\
\hline 14.30 & 7.16 & 19.70 & $\mathrm{PCI} / \mathrm{GM}$ & LASL 77 \\
\hline 6.62 & 1.87 & 19.80 & $\mathrm{PCI} / \mathrm{GM}$ & LAS $\ 77$ \\
\hline 7.10 & 2.07 & 17.43 & $\mathrm{PCI} / \mathrm{GM}$ & LASL 77 \\
\hline 10.39 & 4.30 & 18.60 & PCI / GM & LASL 77 \\
\hline 13.85 & 7.69 & 29.60 & $P C I / G M$ & LASL 77 \\
\hline 11.12 & 10.93 & 10.60 & $\mathrm{PCI} / \mathrm{GM}$ & LASL 77 \\
\hline 6.45 & .75 & 26.60 & PC I / GM & LASL 77 \\
\hline 743 & 2.11 & 25.20 & $\mathrm{PCI} / \mathrm{GM}$ & $-A S L 77$ \\
\hline 9.60 & 4.32 & 16.30 & $\mathrm{PCI} / \mathrm{GM}$ & LASL 77 \\
\hline 12.45 & 4.27 & 16.10 & PCI / GM & LASL 77 \\
\hline 7.37 & 2.22 & 19.79 & $\mathrm{PCI} / \mathrm{GM}$ & LASL 77 \\
\hline 9.61 & 4. 32 & $13 \cdot 10$ & $\mathrm{PCI} / \mathrm{GM}$ & LASL 77 \\
\hline 9.82 & 4.27 & 22.37 & $\mathrm{PCI} / \mathrm{GM}$ & LASL 77 \\
\hline 10.91 & 7.22 & 15.10 & $\mathrm{PCl} / \mathrm{GM}$ & LASL 77 \\
\hline 6.58 & .55 & 12.55 & PCI / GM & LASL 77 \\
\hline 11.52 & 7.18 & 18.80 & $\mathrm{PCI} / \mathrm{GM}$ & LASL 77 \\
\hline 10.60 & 4.42 & 20.80 & $P C I / G M$ & LASL 77 \\
\hline 9.82 & 4. 27 & 21.90 & $\mathrm{PCI} / \mathrm{GM}$ & LASL 77 \\
\hline & 5.34 & 17.80 & PCI / GM & LASL 77 \\
\hline 10.37 & 4.33 & 18.90 & $\mathrm{PCI} / \mathrm{GM}$ & LASL 77 \\
\hline 6.46 & 1.16 & 12.84 & $\mathrm{PCI} / \mathrm{GM}$ & LASL 77 \\
\hline 10.12 & 4.27 & 12.81 & PCI / GM & LASL 77 \\
\hline 14.49 & 9.25 & $18 \cdot 10$ & $\mathrm{PCI} / \mathrm{GM}$ & LASL 77 \\
\hline 12.60 & 6.58 & 15.30 & $\mathrm{PCI} / \mathrm{GM}$ & LASL 77 \\
\hline
\end{tabular}




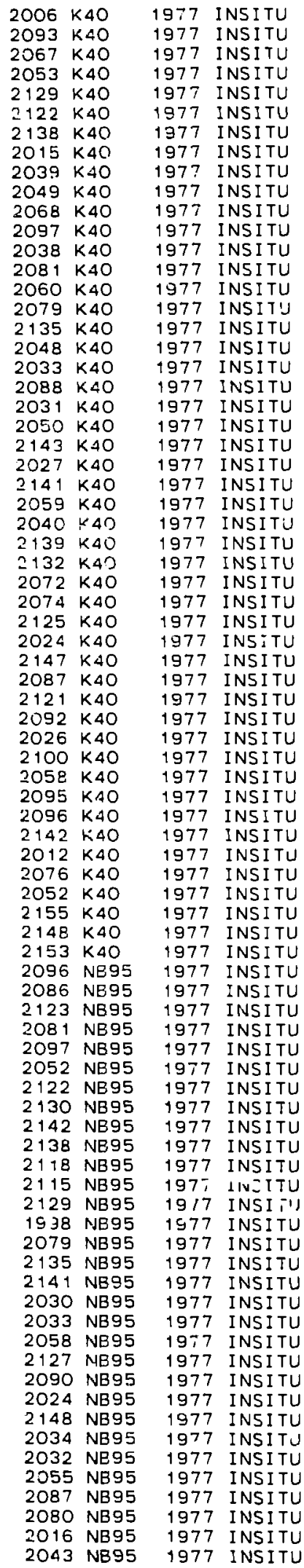

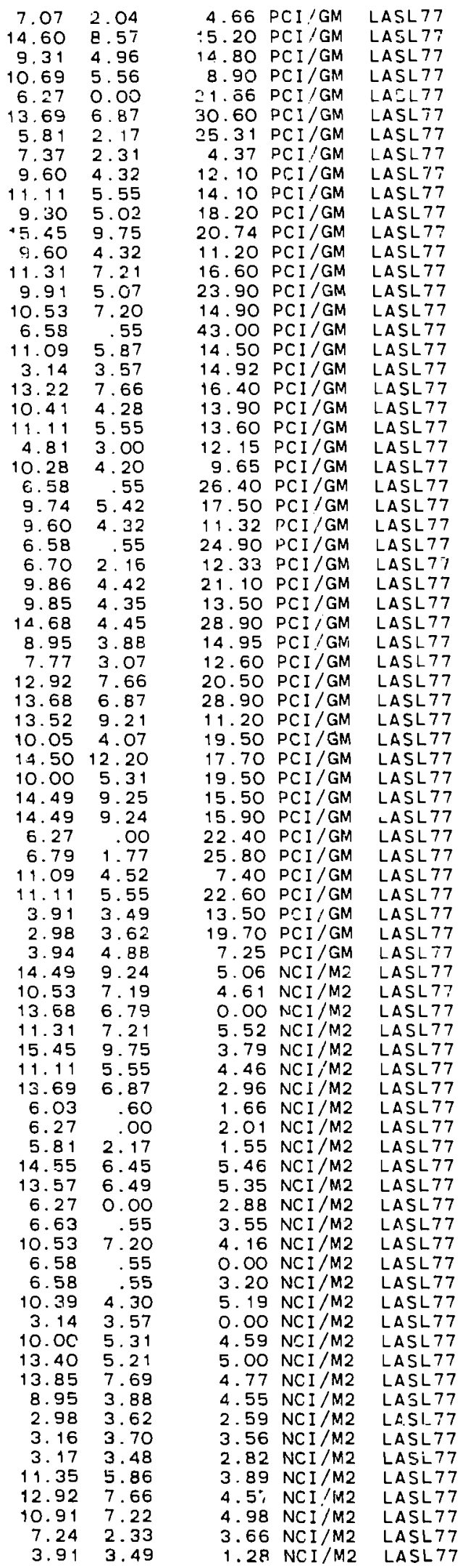




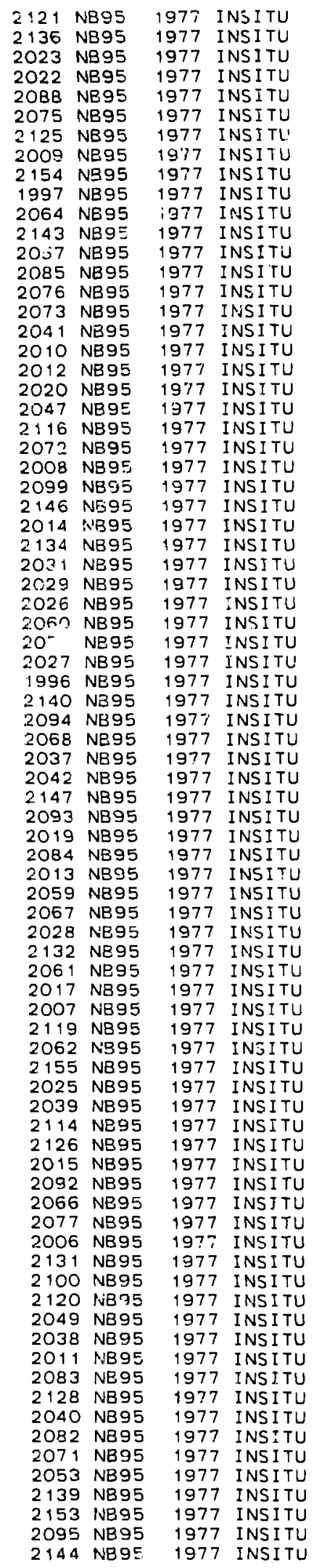

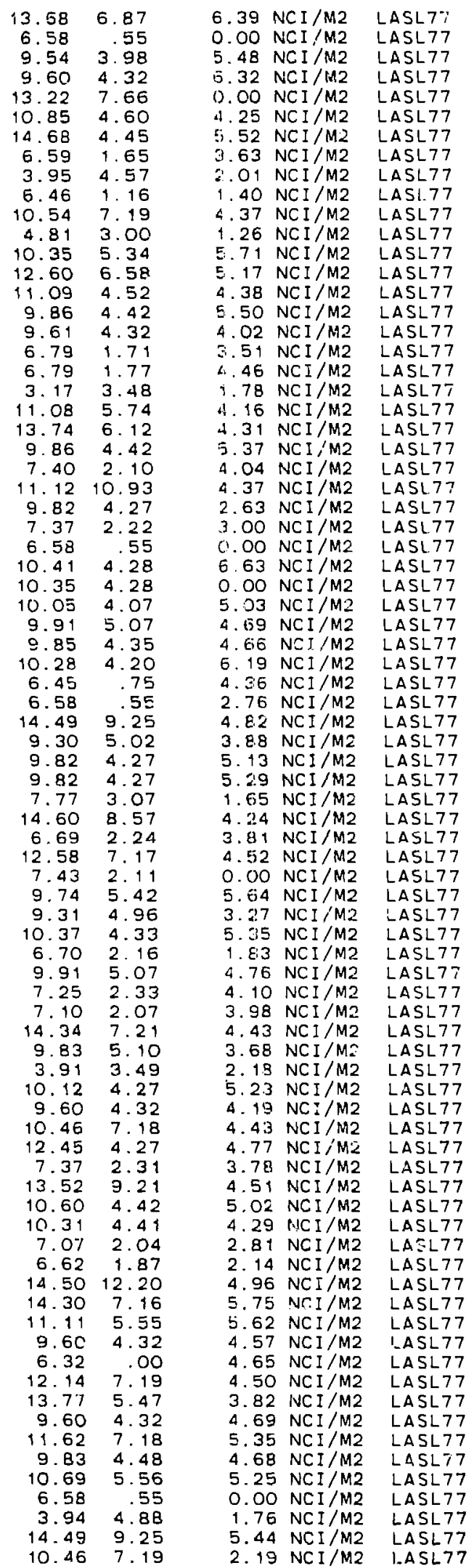




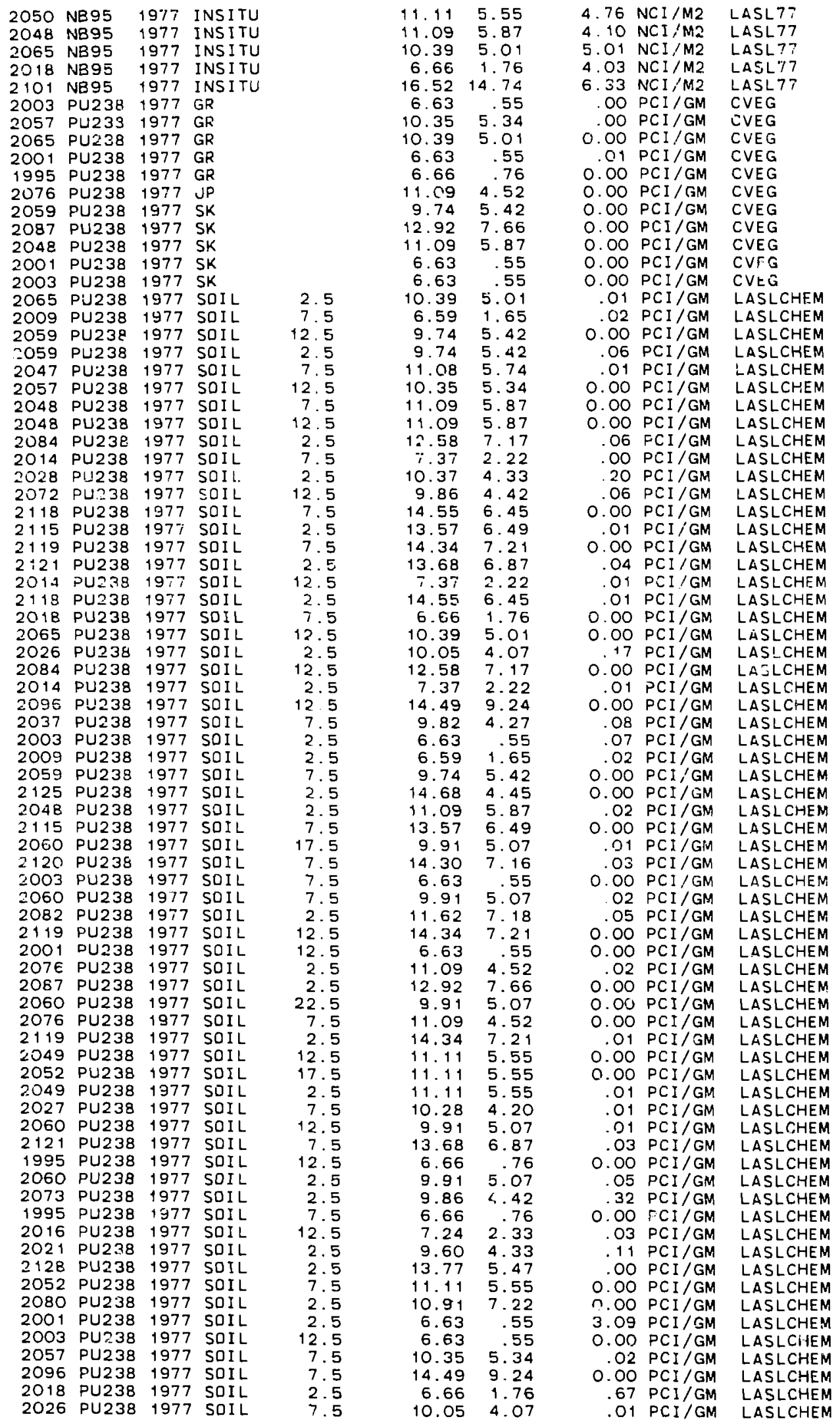




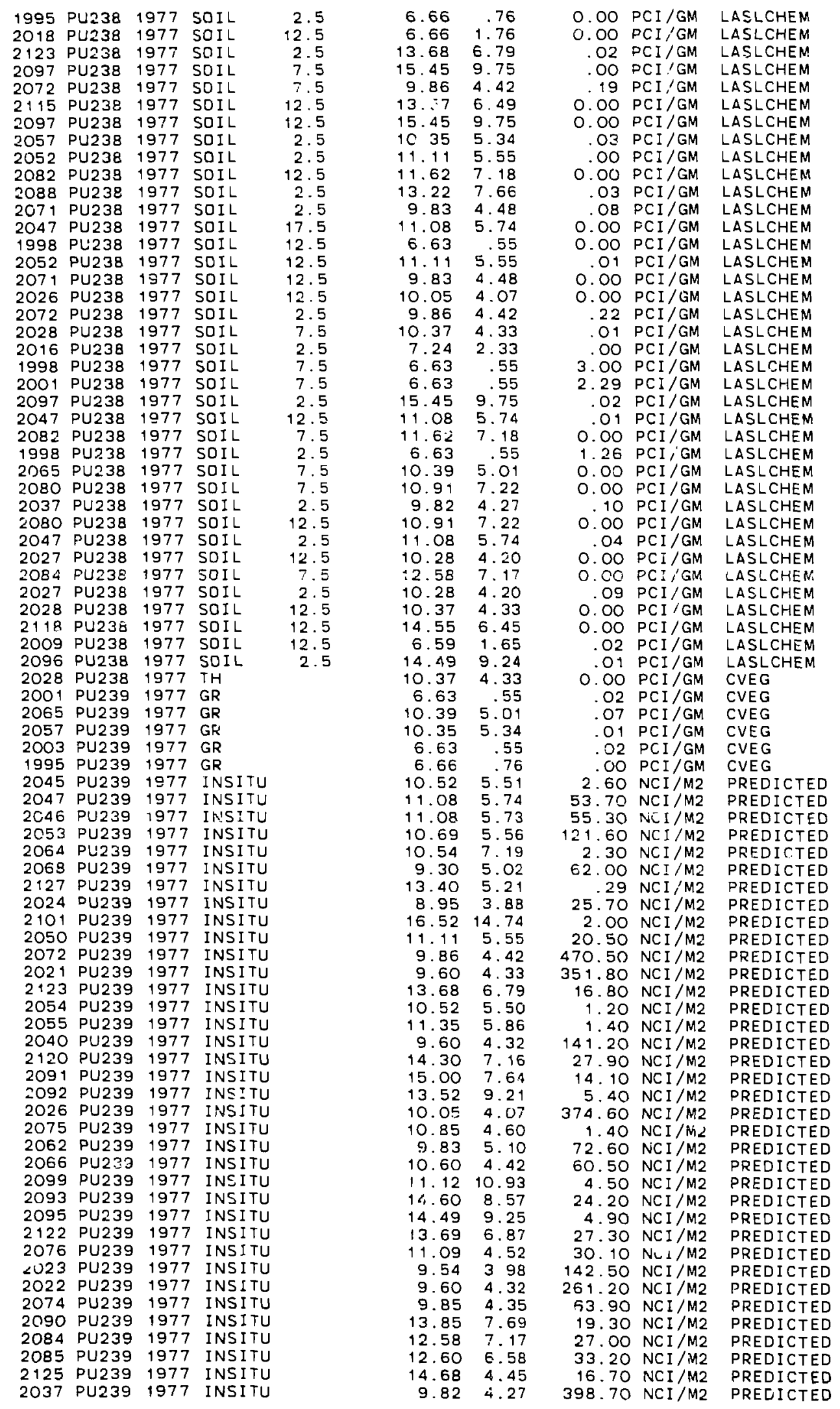


2058 PU239 1977 INSITU 2025 PU239 1977 INSITU 2032 PU239 1977 INSITU 2031 PU239 1977 INSITU 2087 PU239 1977 INSITU 2059 PU239 1977 INSITU 2052 PU239 1977 INSITU 2 C73 PU239 1977 INEITU 2049 PU239 1977 INSITU 2086 PU239 1977 INSITU 2118 PU239 1977 INSITU 2088 PU239 1977 INSITU 2128 PU239 1977 INSITU 2082 PU239 1977 INSITU 2083 PU239 1977 INSITU 2097 PU239 1977 INSITU 2080 PU239 1977 INSITU 2067 PU239 1977 INSITU 2089 PU239 1977 INSITU 2048 PU239 1977 INSITU 2028 PU239 1977 INSITU 2039 PU239 1977 INSITU 2027 PU239 1977 INEITU 2121 PU239 1977 INSITU 2115 PU239 1977 INSITU 2071 PU239 197\% INSITU 2094 PU239 1977 INSITU 2060 PU239 1977 INSITU 2079 PU239 1977 INSITU 2038 PU239 1977 INSITU 2029 FU239 1977 INSITU 2114 PU239 1977 INSITU 2057 OU239 1977 INSITU 2100 PU239 $19 ? 7$ INSITU 2065 PU239 1977 INSITU $207^{\circ}$ PU239 1977 INSITU 2042 PU239 1977 INSITU 2126 PU239 1977 INSITL 2030 PU239 1977 INSITU 2119 PU239 1977 INSITU 2041 PU239 1977 INSITU 2061 PU239 1977 INSITU 2051 PU239 1977 INSITU 2081 PU239 1977 INSITU 2096 PU239 1977 INSITU 2116 PU239 1977 INSITU 2O7E PU239 1977 JP 2087 PU239 1977 SK

2001 FU239 1977 SK 2003 PU239 1977 SK 2048 PU239 1977 SK

2059 PU239 1977 SK

518 PU239 1973 SOIL

534 PU239 1977 SOIL

2057 PU239 1977 SOIL

524 PU239 1973 SOIL

560 PU239 1973 SOIL

525 PU239 1973 SOIL

3002 PU239 1977 SOIL

1995 PU239 1977 SOIL

522 PU239 1973 SOIL

582 PU239 1977 SOIL

581 PU239 1977 SOIL

203 PU239 1972 SOIL

515 PU239 1973 SOIL

564 PU239 1977 SOIL

2082 PU239 1977 SOIL

108 PU239 1948 SOIL

520 PU239 1973 SOIL

580 PU239 1577 SOIL

567 PU239 1977 SOIL

3004 PU239 1977 SOIL

507 PU239 1973 SOIL

107 PU239 1948 SOIL

14 PU239 1950 SOIL

3DO4 PU239 1977 SOIL

517 PU239 1973 SOIL

501 PU239 1973 SOIL

545 PU239 1973 SOIL

2125 PU239 1977 SOIL
10. 12

3. 17

5.31

$10.41 \quad 4.28$

$12.92 \quad 766$

$9.74 \quad 5.42$

11.115 .55

$9.86 \quad 4.42$

$11.11 \quad 5.55$

$10.53 \quad 7.19$

$14.55 \quad 6.45$

13.227 .66

13.77

11.62

12.14

10. 91

9.31

14.03

11.09

10. 37

9.60

10. 26

13.69

13.57

9.83

14.49

9.91

10.53

9.60

10.35

10.46

10.35

14. 50

10.39

10.31

9.82

12.45

$10.3=$

14. 34

9.61

9. 91

11.11

11.31

14.49

13.74

11.09

12.92

6.63

6.63

11.09
9.74

2.5

12.5

2. 5

2.5

2. 5

12.5
2.5

2. 5

2. 5

5.0

2.5

2. 5

12.5

1.3

2. 5

2.5

2. 5

12.5

2. 5

1. 3

1.3

7.5

2.5

2.5

2. 5

2.5
15.45

$12 \ldots .20$ NCI $/ \mathrm{M} 2$

$43^{-} .90 \mathrm{NCI}$ !M2

$1: 20$ NCI I /M2

$10: .50 \mathrm{NCl} / \mathrm{M} 2$

$5=.20 \mathrm{NCI} / \mathrm{M} 2$

$56.90 \mathrm{NCI} / \mathrm{M} 2$

15. $80 \mathrm{NCl} / \mathrm{M} 2$

$-60 \mathrm{NCI} / \mathrm{M}$

$24.60 \mathrm{NCI} / \mathrm{M} 2$

5. $10 \mathrm{NCI} / \mathrm{M} 2$

10. $60 \mathrm{NCI} / \mathrm{M} 2$

42. $90 \mathrm{NCI} / \mathrm{M2}$

$1.60 \mathrm{NCI} / \mathrm{M} 2$

$37.70 \mathrm{NCI} / \mathrm{M} 2$

$65.00 \mathrm{NCI} / \mathrm{M} 2$

$21.70 \mathrm{NCI} / \mathrm{M} 2$

8. $20 \mathrm{NCI} / \mathrm{M} 2$

19.10 NCI /M2

$36.20 \mathrm{NCI} / \mathrm{M} 2$

$41.20 \mathrm{NCI} / \mathrm{M} 2$

$504.90 \mathrm{NCI} / \mathrm{M2}$

$256.90 \mathrm{NCI} / \mathrm{M} 2$

155. OO NCI / M2

$17.90 \mathrm{NCI} / \mathrm{M} 2$

13. $10 \mathrm{NCI} / \mathrm{M} 2$

177. $20 \mathrm{NCI} / \mathrm{M} 2$

$15.70 \mathrm{NCI} / \mathrm{M} 2$

$122.20 \mathrm{NCI} / \mathrm{M} 2$

$5.80 \mathrm{NCI} / \mathrm{M} 2$

$170.80 \mathrm{NCI} / \mathrm{M} 2$

8. $10 \mathrm{NCI} / \mathrm{M} 2$

4. $50 \mathrm{NCI} / \mathrm{M} 2$

$49.30 \mathrm{NEI} / \mathrm{M} 2$

4. $20 \mathrm{NCI} / \mathrm{M} 2$

$94.80 \mathrm{NCI} / \mathrm{M} 2$

1. $20 \mathrm{NCI} / \mathrm{M} 2$

352 . $10 \mathrm{NCI} / \mathrm{M} 2$

$7.40 \mathrm{NCI} / \mathrm{M} 2$

$437.90 \mathrm{NCI} / \mathrm{M2}$

9. $10 \mathrm{NCI} / \mathrm{M} 2$

255 . $00 \mathrm{NCI} / \mathrm{M} 2$

$22.50 \mathrm{NCI} / \mathrm{M} 2$

$257.10 \mathrm{NCI} / \mathrm{M2}$

$27.60 \mathrm{NCI} / \mathrm{M} 2$

15. $10 \mathrm{NCI} / \mathrm{M} 2$

10. $90 \mathrm{~N}=\mathrm{I} / \mathrm{M} 2$ $.01 \mathrm{PCI} / \mathrm{GM}$ $.02 \mathrm{PCI} / \mathrm{GM}$

$0.00 \mathrm{PCI} / \mathrm{GM}$ $01 \mathrm{PCI} / \mathrm{GM}$ $01 \mathrm{PCI} / \mathrm{GM}$

$\begin{array}{llr}9.74 & 5.42 & .04 \mathrm{PCI} / \mathrm{GM} \\ 7.19 & 2.24 & 10.00 \mathrm{NCI} / \mathrm{M} 2\end{array}$

$24.04 \quad 15.09$

10. $35 \quad 5.34$

$\begin{array}{ll}7.76 & 2.96\end{array}$

$15.04 \quad 7.62$

$8.25 \quad 2.94$

3.913 .49

$6.66 \quad .76$

$6.82 \quad 2.87$

$21.85 \quad 15.46$

20.8315 .53

$\begin{array}{ll}7.81 & 1.89\end{array}$

$\begin{array}{ll}10.82 & 1.34\end{array}$

$15.03 \quad 3.53$

$11.62 \quad 7.18$

9.98 4.31

$5.72 \quad 3.04$

$19.82 \quad 15.59$

$12.66 \quad 11.54$

$3.91 \quad 3.49$

ט. $57 \quad 1.92$

$9.49 \quad 3.78$

$14.27 \quad 5.80$

$3.91 \quad 3.49$

$\begin{array}{ll}7.45 & 2.21\end{array}$

$\begin{array}{rr}6.57 & .71 \\ 10.30 & 5.36\end{array}$

$14.68 \quad 4.45$

2. $20 \mathrm{NCI} / \mathrm{M} 2$

$.01 \mathrm{PCI} / \mathrm{GM}$

PREDICTED PREDICTED PREDICTED PREDICTED PREDICTED PREDICTED PREDICTED PREDICTED PREDICTED PREDICTED PREDICTED PREDICTED

PREDICTED

PRE.DICTED

PREDICTED

PREDICTED

PREDICTED

PREDICTED

PREDICTED

PREDICTED

PREDICTED

PREDICTED

PREDICTED

PREDICTED

PREDICTED

PREDICTED

PREDICTED

PREDICTED

PREDICTED

PREDICTED

PREDICTED

PREDICTED

PREDICTED

PREDICTED

PREDICTED

PREDICTED

PREDICTED

PREDICTED

PREDICTED

PREDICTED

PREDICTED

PREDICTED

PREDICTED

PREDICTED

PREDICTED

PREDICTED

CVEG

CVEG

CVEG

CVEG

CVEG

CVEG 


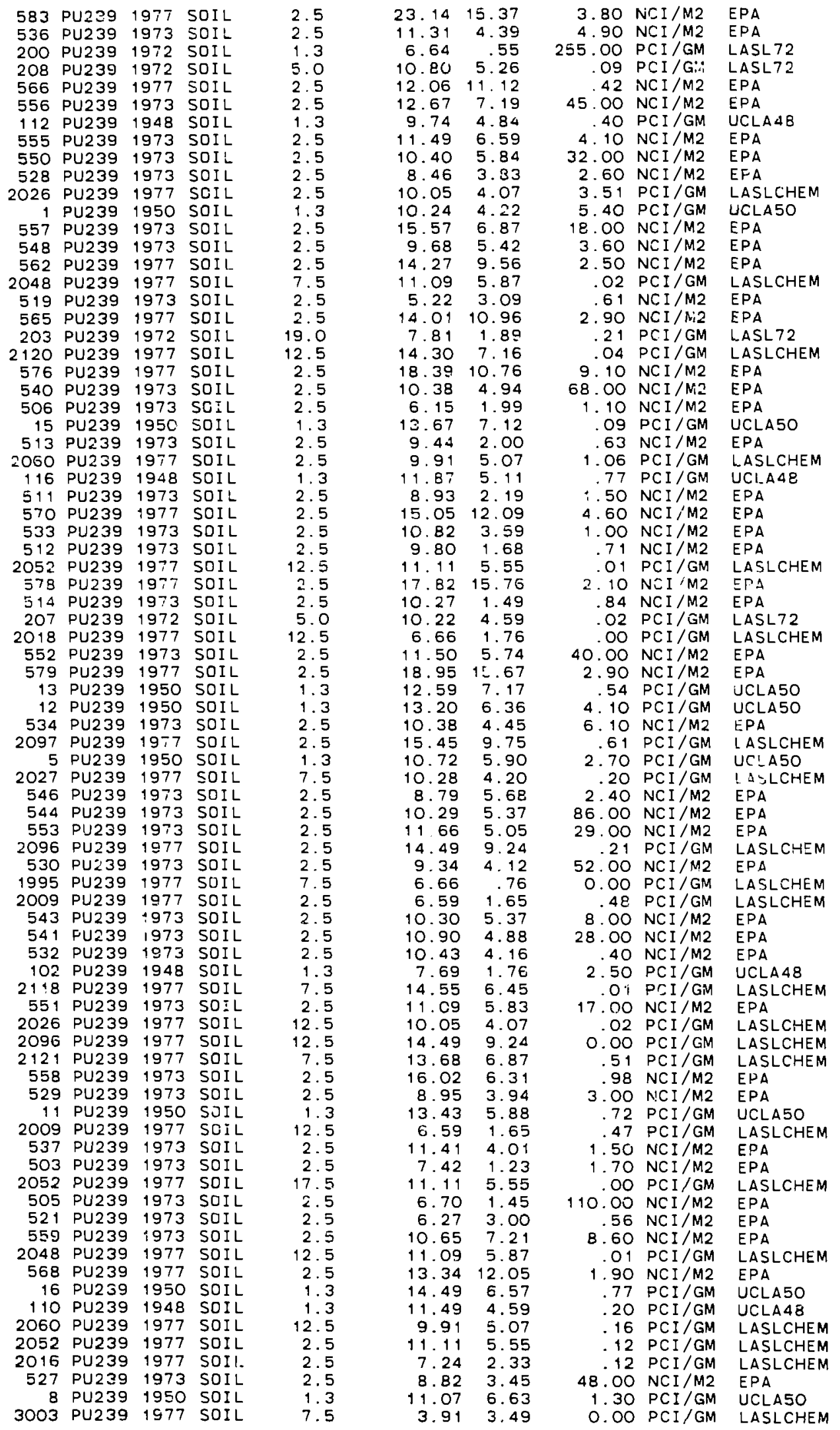




\begin{tabular}{|c|c|c|c|c|c|c|}
\hline 2003 & $\begin{array}{l}\text { PU239 } \\
\text { PU2 } 39\end{array}$ & $\begin{array}{l}1950 \\
1977\end{array}$ & $\begin{array}{l}\text { SOIL } \\
\text { SOIL }\end{array}$ & $\begin{array}{l}1.3 \\
2.5\end{array}$ & $\begin{array}{r}10.36 \\
6.63\end{array}$ & $\begin{array}{r}4.68 \\
.55\end{array}$ \\
\hline 120 & PU239 & 1977 & SOIL & 7.5 & 14.30 & $\begin{array}{l}7.53 \\
7.16\end{array}$ \\
\hline 111 & PU239 & 1948 & SOIL & 1.3 & 10.44 & 4.84 \\
\hline 3 & PU239 & 1950 & SOIL & 1.3 & 10.34 & 5.01 \\
\hline 523 & PU239 & 1973 & SOIL & 2.5 & 7.25 & 2. 92 \\
\hline 206 & Pบ239 & 1972 & SOIL & 5.0 & 9.59 & 3.89 \\
\hline 575 & PU239 & 1977 & SOIL & 2.5 & 18.33 & 10.92 \\
\hline 4 & $P \cup 239$ & 1950 & SOIL & 1.3 & 11.19 & 4.60 \\
\hline 569 & Pบ239 & 1977 & SOI! & 2.5 & 14.14 & 12.17 \\
\hline 2097 & PU239 & 1977 & SOIL & 12.5 & 15.45 & 9.75 \\
\hline 113 & PU239 & 1948 & SOIL & 1.3 & 11.70 & 4.85 \\
\hline 201 & PU239 & 1972 & SOIL & 1.3 & 6.64 & \\
\hline 2080 & PU239 & 1977 & SOIL & 2.5 & 10.91 & 7.22 \\
\hline 200 & PU239 & 1972 & SOIL & 19.0 & 6.64 & \\
\hline 2049 & PU239 & 1977 & SOIL & 12.5 & 11.11 & 5.5 \\
\hline 205 & PU239 & 1972 & SOIL & 5.0 & 9.03 & 3.2 \\
\hline 2027 & PU239 & 1977 & SOIL & 2.5 & 10.28 & 4.20 \\
\hline 201 & PU239 & 1972 & SOIL & 19.0 & 6.64 & \\
\hline 509 & Pบ239 & 1973 & SCIL & 2.5 & 7.36 & 1.85 \\
\hline 531 & PU239 & 1973 & SOIL & 2.5 & 9.95 & 4. 16 \\
\hline 3001 & PU239 & 1977 & SOI L & 2.5 & 3.91 & 3. 49 \\
\hline 508 & PU239 & 1973 & SOIL & 2.5 & 6.65 & 2.07 \\
\hline 2115 & $P \cup 239$ & 1977 & SOIL & 7.5 & 13.57 & 6.49 \\
\hline 577 & PU239 & 1977 & SOI L & 2.5 & 16.88 & 15.86 \\
\hline 2072 & $P \cup 239$ & $197 ?$ & SOI L & 12.5 & 9.86 & 4.42 \\
\hline 200 & $P \cup 239$ & 1972 & SOIL & 5.0 & 6.64 & \\
\hline 202 & Pบ239 & 1972 & SOIL & 19.0 & 7.23 & 1.23 \\
\hline 1995 & PU239 & 1977 & SOIL & 2.5 & 6.66 & \\
\hline 2047 & PU239 & 1977 & SOIL & 2.5 & 11.08 & 5.74 \\
\hline 2126 & PU239 & 1977 & SOIL & 2.5 & 12.45 & 4.27 \\
\hline 554 & PU239 & 1973 & SOIL & 2.5 & 10.63 & 7.12 \\
\hline 573 & PU239 & 1977 & SOIL & 2.5 & 16.90 & 11.61 \\
\hline 206 & PU239 & 1972 & SOIL & 19.0 & 9.59 & 3.89 \\
\hline 2060 & PU239 & 1977 & SOIL & 17.5 & 9.91 & 5.07 \\
\hline 2003 & Pบ239 & 1977 & SOIL & 7.5 & 6.63 & 5 \\
\hline 500 & $P \cup 239$ & 1973 & SOI L & 2.5 & 6.59 & .4 \\
\hline 572 & PU239 & 1977 & SOI L & 2.5 & 16.48 & 12.4 \\
\hline 2096 & PU239 & 1977 & SCIL & 7.5 & 14.49 & 9.2 \\
\hline 561 & PU239 & 1977 & SOIL & 2.5 & 13.41 & 10.1 \\
\hline 563 & Pบ239 & 1977 & SOIL & 2.5 & 14.61 & 8.9 \\
\hline 201 & $P U \approx 39$ & 1972 & SOIL & 5.0 & 6.64 & .5 \\
\hline 2065 & PU239 & 1977 & SO! & 75 & 10.39 & 5.0 \\
\hline 547 & PU239 & 1973 & $501 \mathrm{~L}$ & 2 & 9.24 & \\
\hline 2014 & PU239 & 1977 & SOIL & 7.5 & 7.37 & 2.2 \\
\hline 2076 & PU239 & 1977 & SOIL & 12.5 & 11.09 & 4.5 \\
\hline 2071 & PU239 & 1977 & SOIL & & 9.83 & 4.48 \\
\hline 103 & PU239 & 1948 & SOIL & 1.3 & 8.06 & 2.1 \\
\hline 504 & $P \cup 239$ & 1973 & $501 \mathrm{~L}$ & 2.5 & 6.95 & 1.3 \\
\hline 207 & FU239 & 1972 & SOIL & 19.0 & 10.22 & 4.59 \\
\hline 2065 & PU239 & 1977 & 50 IL & 2 & 10.39 & 5.0 \\
\hline 2001 & PU239 & 1977 & SOIL & 12 & 6.63 & \\
\hline 571 & PU239 & 1977 & SOIL & 2.5 & 15.86 & 12.0 \\
\hline 2047 & PU239 & 1977 & SOIL & 12.5 & 11.08 & 5.7 \\
\hline 3002 & PU239 & 1977 & SOIL & 2.5 & 3.91 & 3. \\
\hline 3004 & PU239 & 1977 & SOIL & 2.5 & 3.91 & 3.4 \\
\hline 2118 & PU239 & 1977 & SOIL & 2.5 & 14.55 & 6.4 \\
\hline 2014 & $P \cup 239$ & 1977 & SOIL & 2.5 & 7.37 & 2.2 \\
\hline 2073 & 3 PU239 & 1977 & SOIL & 2.5 & 9.86 & 4.4 \\
\hline 2052 & - Pน239 & 1977 & SOIL & $27 . \Xi$ & 11.11 & \\
\hline 10 & PU239 & 1950 & so & 1.3 & 12.84 & \\
\hline 2121 & $P \cup 239$ & 1977 & SOI & 2.5 & 13.68 & 6.8 \\
\hline 2059 & $P \cup 239$ & 1977 & Sol & 7.5 & 9.74 & 5 \\
\hline 2080 & $P \cup 239$ & 1977 & so & 12 & 10.91 & \\
\hline 2047 & PU239 & 1977 & & 7.5 & 11.08 & 5.7 \\
\hline 3002 & ! $P \cup 239$ & $19^{-7} 7$ & SOI & 12.5 & 3.91 & 3.2 \\
\hline 2059 & PU239 & 1977 & 50 & 12.5 & 9.74 & \\
\hline 3003 & 3 PU239 & 1977 & SOI & 12.5 & 3. 91 & 3.2 \\
\hline 538 & Pบ239 & 1973 & $50 \mathrm{I}$ & 2.5 & 11.41 & 3.7 \\
\hline 2123 & ( PU239 & 1977 & 501 & 2.5 & 13.68 & \\
\hline 2119 & $P \cup 239$ & 1977 & SOIL & 7.5 & 14.34 & 7.2 \\
\hline 2052 & Pบ239 & 1977 & SOI L & 32.5 & 11.11 & 5. \\
\hline 549 & PU239 & 1973 & 501 & 2.5 & 11.08 & \\
\hline 2028 & PU239 & 1977 & SOI & 12.5 & 10.37 & 4.3 \\
\hline 1998 & PU239 & 1977 & & 2.5 & 6.63 & \\
\hline 3001 & PU239 & 1977 & SOIL & 12.5 & 3.91 & \\
\hline 2119 & PU2 39 & 1977 & SOIL & 2.5 & 14.34 & 7.2 \\
\hline 205 & ; PU239 & 1972 & SOI & $19 . \mathrm{C}$ & 9.03 & 3.2 \\
\hline 2120 & PU239 & 1977 & SOIL & 2.5 & 14.30 & \\
\hline 2084 & 1 PU239 & 1977 & SOIL & 2.5 & 12.58 & \\
\hline
\end{tabular}

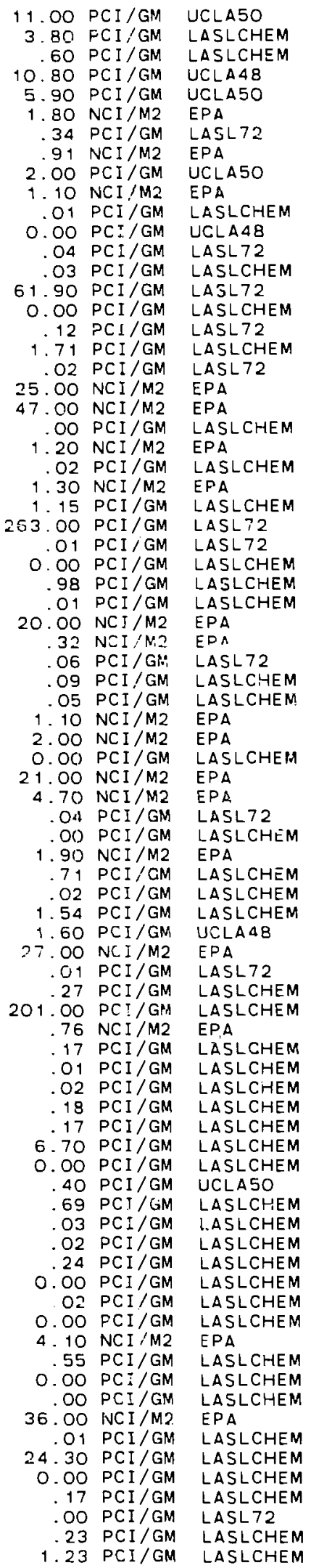




\begin{tabular}{|c|c|c|c|c|c|c|c|c|c|}
\hline 2047 & PU239 & 1977 & SOIL & 22.5 & 11.08 & 5.74 & $.01 \mathrm{~F}$ & $\mathrm{PCI} / \mathrm{GM}$ & LASLCHEM \\
\hline $\begin{array}{r}2014 \\
104\end{array}$ & PU239 & 1977 & SOIL & 12.5 & 7.37 & 2.22 & .15 & $P C I, G M$ & LASLCHEM \\
\hline $\begin{array}{r}104 \\
2072\end{array}$ & PU239 & 1948 & SOIL & 1.3 & 8.99 & 3.23 & 1.30 & PCI / CMM & UCLAAE \\
\hline 2072 & PU239 & 1977 & SOIL & 7.5 & 9.86 & 4.42 & 3.88 & PCI / GM & LASLCHEM \\
\hline 535 & PU239 & 1973 & SUIL & 2.5 & 10.87 & 4.55 & .54 & NCI / M2 & EPA \\
\hline 105 & PU239 & 1948 & SOIL & 1.3 & 8.41 & 3.23 & .50 & PCI / GM & UCLA 48 \\
\hline 2052 & PU239 & 1977 & SOIL & 7.5 & 11.11 & 5.55 & .00 & PCI / GM & LASLCHEM \\
\hline 2115 & PU239 & 1977 & SOIL & 2.5 & 13.57 & 6.49 & 23 & $P C I / G M$ & LASLCHEM \\
\hline 2016 & PU239 & 1977 & SOIL & 12.5 & 7.24 & 2.33 & .68 & PCI / GM & LASLCHEM \\
\hline 2018 & PU239 & 1977 & SOIL & 7.5 & 6.66 & 1.76 & 0.00 & $\mathrm{PCI} / \mathrm{GM}$ & LASLCHEM \\
\hline 18 & $P \cup 25=$ & 1950 & SOIL & 1.3 & 14.72 & 7. 12 & .86 & PCI / GM & UCLA5D \\
\hline 2047 & $P \cup 239$ & 1977 & SOIL & 17.5 & 11.08 & 5.74 & .01 & $\mathrm{PCI} / \mathrm{GM}$ & LASLCHEM \\
\hline 2003 & $P \cup 239$ & 1977 & SOIL & 12.5 & 6.63 & .55 & 0.00 & PCI / GM & LASLSHEM \\
\hline 204 & $P \cup 239$ & $\$ 972$ & SOIL & 1.3 & 8.45 & 2.59 & .13 & PCI / GM & LASL 72 \\
\hline 502 & PU239 & 1973 & SOIL & 2.5 & 6.46 & 1.16 & .31 & $\mathrm{NCI} / \mathrm{M} 2$ & EPA \\
\hline 101 & PU239 & 1948 & SOIL & 1.3 & 7.46 & 1.50 & 1.10 & $\mathrm{PCI} / \mathrm{GM}$ & UCLA $4 B$ \\
\hline 2076 & $P \cup 239$ & 1977 & SOIL & 7.5 & 11.09 & 4.52 & .02 & $\mathrm{PCI} / \mathrm{GM}$ & LASLCHEM \\
\hline 2084 & PU239 & 1977 & SOIL & 7.5 & 12.58 & 7.17 & .06 & PCI / GM & LASLCHEM \\
\hline 2097 & PU239 & 1977 & SOIL & 7.5 & 15.45 & 9.75 & .15 & $\mathrm{PCI} / \mathrm{GM}$ & LASLCHEM \\
\hline 2018 & PU239 & 1977 & SOIL & 2.5 & 6.66 & 1.76 & .67 & $P C I / G M$ & LASLCHEM \\
\hline 526 & PU239 & 1973 & SOIL & 2.5 & 7.91 & 3.31 & 12.00 & NCI / M2 & EPA \\
\hline 2027 & PU239 & 1977 & SOIL & 12.5 & 10.28 & 4.20 & .07 & PCI / GM & LASLCUEM \\
\hline 2052 & PU239 & 1977 & SOIL & 57.5 & 11.11 & 5.55 & .01 & PCI / GM & LASLCHEM \\
\hline$E$ & PU239 & 1950 & SOIL & 1.3 & 10.36 & 6.35 & .40 & $P C I / G M$ & UCLA5O \\
\hline 2026 & PU2 39 & 1977 & SOIL & 7.5 & 10.05 & 4.07 & .12 & PCI / GM & LASLCHEM \\
\hline 2082 & PU239 & 1977 & SOIL & 7.5 & 11.62 & 7.18 & .01 & $P C I / G M$ & LASLCHEM \\
\hline 2001 & PU2 39 & 1977 & SOIL & 7.5 & 6.63 & .55 & 44.40 & $P C I / G M$ & LASLCHEM \\
\hline 202 & PU2 39 & 1972 & SOIL & 5.0 & 7,23 & 1.23 & 0.00 & PCI / GiM & LASL 72 \\
\hline 2119 & PU239 & 1977 & SOIL & 12.5 & 14.34 & 7.21 & 0.00 & $P C I / G M$ & LASLCHEM \\
\hline 204 & $P \cup 239$ & 1972 & SOIL & 19.0 & 8.45 & 2.59 & .17 & PCI / GM & LASL 72 \\
\hline 2057 & $P \cup 239$ & -977 & SOIL & 2.5 & 10.35 & 5.34 & .70 & $\mathrm{PCI} / \mathrm{GM}$ & LASLCHEM \\
\hline 109 & PU239 & 1948 & SOI'- & 1.3 & 9.67 & 4.57 & 1.30 & PCI / GM & UCLA48 \\
\hline 2060 & PU230 & 1977 & SOIL & 7.5 & 9.91 & 5.07 & .30 & $\mathrm{PCI} / \mathrm{GM}$ & LASLCHEM \\
\hline 2082 & PU239 & 1977 & SOIL & 2.5 & 11.62 & 7.18 & .95 & $\mathrm{PCI} / \mathrm{GM}$ & LASLCHEM \\
\hline 2057 & PU239 & 1977 & SOIL & 7.5 & 10.35 & 5.34 & .38 & $P C I / G M$ & LASLCHEM \\
\hline 2097 & PU239 & 1977 & SOIL & 22.5 & 15.45 & 9.75 & .00 & PCI $/ G M$ & $\triangle A S_{i} C H E M$ \\
\hline 2084 & PU239 & 1977 & SOIL & 12.5 & 12.58 & 7.17 & .01 & PCI / GM & LASLCHEM \\
\hline 3003 & Pบ2 39 & 1977 & SOIL & 2.5 & 3.91 & 3.49 & .01 & PCI / GM & LASLCHEM \\
\hline 2028 & PU239 & 1977 & SOIL & & 10.37 & 4.33 & .11 & PCI / GM & LASLCHEM \\
\hline 2126 & PU239 & 1977 & SOIL & 7.5 & 12.45 & 4.27 & 0.00 & $\mathrm{PCI} / \mathrm{GM}$ & LASLCHEM \\
\hline 2087 & PU239 & 4977 & SOIL & 2.5 & 12.92 & 7.66 & .00 & $\mathrm{PCI} / \mathrm{GM}$ & LASLCHEM \\
\hline 2060 & PU239 & 1977 & SOIL & 22.5 & 9.91 & 5.07 & .05 & $\mathrm{PCI} / \mathrm{GM}$ & LASLCHEM \\
\hline 574 & PU239 & 1977 & SOIL & 5 & 17.51 & 11.20 & 6.10 & NC I / M2 & EPA \\
\hline 204 & PU239 & 1972 & SOIL & 5.0 & 8.45 & 2.59 & .75 & $\mathrm{PCI} / \mathrm{GM}$ & LASL 72 \\
\hline 542 & PU239 & 1973 & SOIL & & 10.30 & 5.37 & 28.00 & NC I / M2 & \\
\hline 202 & PU239 & 1972 & SOIL & 1.3 & 7.23 & 1.23 & .43 & PC I / GM & LASL 72 \\
\hline 539 & PLI239 & 1973 & SOIL & 2.5 & 12.28 & 3.54 & 1.30 & NCI / M2 & EPA \\
\hline 2118 & PU239 & $: 277$ & SOIL & 12.5 & 14.55 & 6.45 & 0.20 & $P C 1 / G M$ & LASLCHEM \\
\hline 510 & PU239 & 1973 & SOIL & 2.5 & 8.63 & 2.52 & 2.30 & NC I / M2 & EPA \\
\hline 2028 & PU:39 & 1977 & SOIL & 2.5 & 10.37 & 4.33 & 4.07 & $\mathrm{PCI} / \mathrm{GM}$ & LASLCHEM \\
\hline 2059 & PU239 & 1977 & SOIL & 2.5 & 9.74 & $5 \quad 42$ & 1.21 & $\mathrm{PCI} / \mathrm{GM}$ & LASLCHEM \\
\hline 2128 & PU239 & 1977 & SDIL & 2.5 & 13.77 & 5.47 & .06 & PCI/GM & LASLCHEM \\
\hline 114 & $F \cup=9$ & 1948 & SDIL & 1.3 & 10.68 & 5.11 & 3.80 & $\mathrm{PCI} / \mathrm{GM}$ & UCLA48 \\
\hline 208 & $p^{\prime \prime}-39$ & 1972 & SOIL & 19.0 & 10.80 & 5.26 & .03 & $P C I / G M$ & $L A S L 72$ \\
\hline 2049 & ป239 & 1977 & SOIL & 2.5 & 11.11 & 5.55 & .25 & $\mathrm{PCI} / \mathrm{GM}$ & LASLCHEM \\
\hline $20 ?$ & PU239 & 1977 & SOIL & & 9.82 & 4.27 & 1.83 & $P C I / G M$ & LASLCHEM \\
\hline .00 & PU239 & 1948 & SOIL & 1.3 & 7.10 & 1.09 & .10 & $\mathrm{PCI} / \mathrm{GM}$ & UCLA 48 \\
\hline 208 & PU239 & 1972 & SOIL & i. 3 & 10.80 & 5.26 & 1.44 & PC I / GM & LASL 72 \\
\hline 115 & PU239 & $19<3$ & SOIL & & 9.90 & 5.10 & .81 & $P C I / G M$ & UCLA AB \\
\hline 2072 & PU239 & 1977 & SOIL & 2.5 & 9.86 & 4.42 & 4.58 & PCI / GM & LASLCHEM \\
\hline 1998 & PU239 & 1977 & SOIL & 12.5 & 6.63 & .55 & .15 & PCI / GM & LASIC.RIEM \\
\hline 207 & PU239 & 1972 & Sol & & 10.22 & $4.5 y$ & .28 & $P C I / G M$ & LASL 72 \\
\hline 2088 & PU239 & 1977 & SOIL & 2.5 & 13.22 & 7.66 & 03 & $P C I / G M$ & LASLCHEM \\
\hline 206 & PU239 & 1972 & SOIL & $1 . \overline{3}$ & 9.59 & 3.89 & .67 & PCI I & LASL 72 \\
\hline 2080 & PU239 & 1977 & so & 7.5 & 10.91 & 7.22 & .02 & PCI / GM & LASLCHEM \\
\hline 203 & PU239 & 1972 & so & 1.3 & 7.81 & 1.89 & .31 & $\mathrm{PCI} / \mathrm{GM}$ & LASL 72 \\
\hline & PU239 & 1950 & & & 11.59 & 7.21 & .20 & PCI;GM & UCLA5O \\
\hline 2021 & PU239 & 1977 & so & & 9.60 & 4.33 & 2.24 & $\mathrm{PCI} / \mathrm{GM}$ & LASLCHEM \\
\hline 3001 & PU239 & 1977 & so & 7.5 & 3.91 & 3.49 & 0.00 & $\mathrm{PCI} / \mathrm{GM}$ & LASLCHEM \\
\hline & PU239 & 1950 & & 1.3 & 11.49 & 5.91 & .40 & $\mathrm{PCI} / \mathrm{GM}$ & UCLA5O \\
\hline 2115 & Pl/239 & 1977 & Sol & 12.5 & 13.57 & 6.49 & 0.00 & $\mathrm{PCI} / \mathrm{GM}$ & LASLCHEM \\
\hline 2001 & PU2: 5 & $: 977$ & SOI & 2.5 & 6.63 & .55 & 64.90 & $P C I / G M$ & LASLCHEM \\
\hline 2009 & PU239 & $: 977$ & SO & 7.5 & 6.59 & 1.65 & .45 & $\mathrm{PCI} / \mathrm{GM}$ & LASLCHEM \\
\hline 205 & PU239 & 1972 & SOI & 1.3 & 9.03 & 3.26 & .29 & $P C I / G M$ & $1-4 S L 72$ \\
\hline 106 & PU239 & 1948 & SOI & 1.3 & 9.90 & 3.23 & 0.00 & $\mathrm{PCI} / \mathrm{GM}$ & UCLA 48 \\
\hline 2065 & PU239 & 1977 & SOIL & 12.5 & 10.39 & 5.01 & 0.00 & $\mathrm{PCI} / \mathrm{GM}$ & LASLCHEM \\
\hline 2048 & PU239 & 1977 & SOIL & 2.5 & 11.09 & 5.87 & .40 & $\mathrm{PCI} / \mathrm{GM}$ & LASLCHEM \\
\hline 2076 & PU239 & 1977 & SDIL & 2.5 & 11.09 & 7.52 &. .44 & PCI / GM & LASLCHEM \\
\hline 1998 & PU239 & 1977 & SOI & 7.5 & 6.63 & .55 & 57.40 & $P C I / G M$ & LASLCHEM \\
\hline 2126 & PU239 & 1977 & SDIL & 12.5 & 12.45 & 4.27 & 0.00 & $P C I / G M$ & LASLCHEM \\
\hline
\end{tabular}




\begin{tabular}{|c|c|c|c|c|c|c|c|c|c|}
\hline $\begin{array}{l}2071 \\
2028\end{array}$ & $\begin{array}{l}P \cup 239 \\
P \cup 239\end{array}$ & $\begin{array}{l}19775 \\
1977 \quad 1\end{array}$ & $\begin{array}{l}\text { SOIL } \\
\text { TH }\end{array}$ & 12.5 & $\begin{array}{r}9.83 \\
10.37\end{array}$ & $\begin{array}{l}4.48 \\
4.33\end{array}$ & $\begin{array}{l}. O E \\
. O 4\end{array}$ & $\begin{array}{l}P C I / G M \\
P C I / G M\end{array}$ & $\begin{array}{l}\text { LASLCHEM } \\
\text { CVEG }\end{array}$ \\
\hline 2055 & Rบ103 & 19770 & GR & & 11.35 & 5.86 & 1.31 & PCI / GM & LLL GELI \\
\hline 1990 & $R \cup 103$ & 1977 & GR & & 6.64 & .55 & 0.00 & $P C I / G M$ & GELI \\
\hline 2018 & RU 103 & 1977 & GR & & 6.66 & 1.76 & 0.00 & PCI / GM & GELI \\
\hline 1988 & RU 103 & 1977 & GR & & 5.64 & .55 & .57 & $\mathrm{PCl} / \mathrm{GM}$ & LLL GELI \\
\hline 2073 & $R \cup 103$ & 1977 & INS I TU & & 9.36 & 4.42 & 0.00 & $\mathrm{NCI} / \mathrm{M} 2$ & LAS 177 \\
\hline 2022 & RU103 & 1977 & INSITU & & 9.60 & 4.32 & i. 42 & $\mathrm{NCI} / \mathrm{M} 2$ & LASL 77 \\
\hline 2038 & RU 103 & 1977 & INSITU & & 9.60 & 4. 32 & 0.00 & $\mathrm{NCI} / \mathrm{M} 2$ & LASL 77 \\
\hline 2144 & RU 103 & 1977 & INS I TU & & 10.46 & $? .19$ & 0.00 & $\mathrm{NCl} / \mathrm{M} 2$ & LASL77 \\
\hline 2142 & RU 103 & $: 977$ & INSITU & & 6.27 & .00 & 0.00 & $\mathrm{NCl} / \mathrm{M} 2$ & LASL 77 \\
\hline 2012 & RU 103 & $197 \bar{i}$ & INS I TU & & 6.79 & 1.77 & 0.00 & $\mathrm{NCI} / \mathrm{M} 2$ & LASL 77 \\
\hline 2031 & $R \cup 103$ & 1977 & INS I TU & & 10.41 & 4. 28 & 0.00 & $\mathrm{NC1} / \mathrm{M} 2$ & LASL 77 \\
\hline 2011 & $R \cup 103$ & 1977 & INSITU & & 6.32 & .00 & 0.00 & NCI / M2 & LASL 77 \\
\hline 2041 & $R \cup 103$ & 1977 & INSITU & & 9.61 & 4.32 & 1.90 & $\mathrm{NCI} / \mathrm{M2}$ & LASL 77 \\
\hline 2125 & $\mathrm{RU} 103$ & 1977 & INS I TU & & 14.68 & 4.45 & 1.01 & NCI / M2 & LASL 77 \\
\hline 2032 & $R \cup 103$ & 1577 & I NS I TU & & 3.17 & 3.48 & 0.00 & $\mathrm{NCI} / \mathrm{M} 2$ & LASL 77 \\
\hline 2026 & RU 103 & 1977 & I NS I TU & & $1 \mathrm{C} .05$ & 4.07 & 0.00 & $\mathrm{NCI} / \mathrm{M} 2$ & LASL 77 \\
\hline 2023 & RU 103 & 1977 & I NS I TU & & 9.54 & 3.98 & 0.00 & $\mathrm{NC} 1 / \mathrm{M} 2$ & LASL 77 \\
\hline 2052 & RU 103 & 1977 & INSITU & & 11.11 & 5.55 & 0.00 & $\mathrm{NC} 1 / \mathrm{M} 2$ & LASL 77 \\
\hline $2 \mathrm{COB}$ & RU 103 & 1977 & INSITU & & 7.40 & 2.10 & 0.00 & NCI / M2 & LASL 77 \\
\hline 2033 & $\mathrm{RU} 103$ & 1977 & INS I TU & & 3.14 & 3.57 & 0.00 & $\mathrm{NCl} / \mathrm{M} 2$ & LASL 77 \\
\hline 2077 & RU 103 & 1977 & I NSI TU & & 10.31 & 4.41 & 0.00 & $\mathrm{NCI} / \mathrm{M} 2$ & LASL 77 \\
\hline 2007 & RU 103 & 1977 & INSITU & & 7.10 & 2.07 & 1.48 & $\mathrm{NCI} / \mathrm{M} 2$ & LASL 77 \\
\hline 2029 & RU 103 & 1977 & INSITU & & 10.35 & 4.28 & 0.00 & $\mathrm{NCI} / \mathrm{M} 2$ & LASL 77 \\
\hline 2039 & RU 103 & 1977 & INSITL & & 9.50 & 4. 32 & 0.00 & NCI / M2 & LASL 77 \\
\hline 2096 & $R \cup 103$ & 1977 & INSITU & & 14.49 & 9.24 & 1. 32 & $\mathrm{NCI} / \mathrm{MZ}$ & LASL77 \\
\hline 2019 & RU 103 & 1977 & INS ITU & & 6.69 & 2.24 & .93 & $\mathrm{NCI}, \mathrm{M} 2$ & LASL 77 \\
\hline 2146 & $R \cup 103$ & 1977 & INSITU & & y. 82 & 4.27 & 0.00 & NCI / M2 & LASL 77 \\
\hline 2017 & RU103 & 1977 & I NS I TU & & 7.25 & 2.33 & 0.00 & $\mathrm{NCI} / \mathrm{M} 2$ & LASL 77 \\
\hline 2116 & RU 103 & 1977 & I NS I TU & & 13.74 & 6.12 & 0.00 & NCI / M2 & LASL 77 \\
\hline 2086 & FU 103 & 1977 & INS I TU & & 10.53 & 7.19 & 0.00 & $\mathrm{NCI}$ / M2 & LASL 77 \\
\hline 2139 & RU 103 & 1977 & INSITL' & & $5.5 \varepsilon$ & .55 & 0.00 & $N C I / M 2$ & LASL7T \\
\hline 2115 & RL' 103 & 1977 & INSITU & & 13.57 & 6.49 & .88 & NCI / M2 & LASL77 \\
\hline 2092 & RU 103 & 1977 & INSITU & & 13.52 & 9.21 & 1.12 & $\mathrm{NCI} / \mathrm{M} 2$ & LASL 77 \\
\hline 2085 & RU 103 & 1977 & INS ITU & & 12.60 & 6.58 & 0.00 & NCI / M2 & LASL 77 \\
\hline 2079 & RU 103 & 1977 & INSITU & & 10.53 & 7.20 & 0.00 & $\mathrm{NC1}$ / M2 & LASL 77 \\
\hline 1997 & RU 103 & 1977 & I NS I TL' & & 6.46 & 1.16 & 0.00 & $\mathrm{NC1} / \mathrm{M} 2$ & LASL 77 \\
\hline 2080 & RU 103 & 1977 & INSITU & & 10.91 & 7.22 & 1.04 & NCI / M2 & LASL 77 \\
\hline 2147 & RU 103 & 1977 & INSITU & & 7.77 & 3.07 & 0.00 & $\mathrm{NCI} / \mathrm{M} 2$ & LASL 77 \\
\hline 2132 & $R \cup 103$ & 1977 & I NS I TU & & 6.70 & 2.16 & 0.00 & NCI / M2 & LA $5 L 77$ \\
\hline 2020 & RU 103 & 1977 & INS I TU & & 3.17 & 3.48 & 0.00 & NCI / M2 & LASL 77 \\
\hline 2120 & RU 103 & 1977 & INSITU & & 14.30 & 7.16 & 1.59 & $\mathrm{NCI} / \mathrm{M} 2$ & LASL 77 \\
\hline 2057 & RU 103 & 1977 & INS I TU & & 10.35 & 5.34 & 0.00 & $\mathrm{NCI} / \mathrm{M} 2$ & LASL 77 \\
\hline 2016 & $R \cup 103$ & 1977 & INS I TL & & 7.24 & 2.33 & 0.00 & $\mathrm{NCl} / \mathrm{Ni} 2$ & LASL 77 \\
\hline 2082 & $R \cup 103$ & 1977 & INS I TU & & 11.52 & 7.18 & 1.25 & $\mathrm{NCI}, \mathrm{M} 2$ & LASL 77 \\
\hline 2123 & $R \cup 103$ & 1977 & INS I TU & & 13.68 & 6.79 & 0.00 & NCI / M2 & LASL 77 \\
\hline 2049 & RUt03 & 1977 & INSITU & & 11.11 & 5.53 & 0.00 & $\mathrm{NCI} / \mathrm{M} 2$ & LASL77 \\
\hline 2097 & RU 103 & 1077 & INSITU & & 15.45 & 9.75 & 0.00 & $\mathrm{NCI} / \mathrm{M} 2$ & LASL 77 \\
\hline 2072 & RU 103 & $: 977$ & INS I TU & & 9.86 & 4.42 & 0.00 & $\mathrm{NCI} / \mathrm{M} 2$ & LASL 77 \\
\hline 2118 & RU 103 & 1977 & INSITU & & 14.55 & 6.45 & 0.00 & $\mathrm{NCI} / \mathrm{ME}$ & LASL 77 \\
\hline 2059 & RU 103 & 1977 & INS ITU & & 9.74 & 5.42 & .94 & $\mathrm{NCI} / \mathrm{M} 2$ & LASL77 \\
\hline 2087 & RU 103 & 1977 & INSITU & & 12.92 & 7.66 & 0.00 & NCI / M2 & LASL7 7 \\
\hline 2134 & RU 103 & 1977 & INSITU & & 6.58 & .55 & 0.00 & $\mathrm{NCI} / \mathrm{M} 2$ & LASL 77 \\
\hline 2101 & RU 103 & 1977 & INSITU & & 16.52 & 14.74 & 0.00 & $\mathrm{NCI} / \mathrm{M} 2$ & L. $S\llcorner 77$ \\
\hline 2135 & $\mathrm{RU} 103$ & 1977 & INSITU & & $6.5 \mathrm{~B}$ & .55 & 0.00 & $\mathrm{NCl} 1 / \mathrm{M}_{2}$ & LASL 77 \\
\hline 2126 & RU 103 & 1977 & INS I TU & & 12.45 & 4.27 & 0.00 & NCI / M2 & LASL 77 \\
\hline 2122 & RU 103 & 1977 & INSITU & & 13.69 & 6.87 & 0.00 & $\mathrm{NCI} / \mathrm{M} 2$ & LASL 77 \\
\hline 2055 & RU 103 & 1977 & INSITU & & 11.35 & 5.86 & .87 & $\mathrm{NICI} / \mathrm{M} 2$ & LASL 77 \\
\hline 2075 & RU 103 & 1977 & INSITU & & 10.35 & 4.60 & 0.00 & $\mathrm{NCI} / \mathrm{M} 2$ & LASL 77 \\
\hline 1996 & RU 103 & 1977 & INSITU & & 6.45 & .75 & 0.00 & $\mathrm{NCI}$ / M2 & LASL 77 \\
\hline 2010 & RU 103 & 1977 & INSITU & & 6.79 & 1.71 & 0.00 & NCI / M2 & LASL 77 \\
\hline 2099 & RU 103 & 1977 & INSITU & & 11.12 & 10.93 & 0.00 & $\mathrm{NCI} / \mathrm{M} 2$ & LASL 77 \\
\hline 2136 & RU103 & 1977 & INSITU & & 6.58 & .55 & 0.00 & NCI / M2 & LASL 77 \\
\hline 2053 & RU 103 & 1977 & INS ITU & & 10.69 & 5.56 & 0.00 & NCI / M2 & LASL 77 \\
\hline 2028 & RU 103 & 1977 & INS I TU & & 10.37 & 4.33 & 1.26 & $\mathrm{NCI} / \mathrm{M} 2$ & LASL7 7 \\
\hline 2095 & RU Y O3 & 1977 & INSITU & & 14.49 & 9.25 & 0.00 & $\mathrm{NCI} / \mathrm{M} 2$ & LASL 77 \\
\hline 2014 & RU 103 & 1977 & INSITU & & 7.37 & 2.22 & 0.00 & $\mathrm{NCI} / \mathrm{M} 2$ & LASL 77 \\
\hline 2015 & RU 103 & 1977 & INSI TU & & 7.37 & 2.31 & .60 & NCI / M2 & LASL 77 \\
\hline 2009 & RU 103 & 1977 & INSITU & & 6.59 & 1.65 & 0.00 & NCI / M 2 & LASL 77 \\
\hline 2081 & RU103 & 1977 & INSITU & & 11.31 & 7.21 & .75 & $\mathrm{NCI} / \mathrm{M} 2$ & LASL 77 \\
\hline 2024 & $R U 103$ & 1977 & INSITU & & 8.95 & 3.88 & 0.00 & $\mathrm{NCI} / \mathrm{M} 2$ & LAS $\angle 77$ \\
\hline 2066 & RU 103 & 1977 & INS I TU & & 10.60 & 4.42 & 0.00 & $\mathrm{NCI} / \mathrm{M} 2$ & LASL 77 \\
\hline 2148 & R:1103 & 1977 & INSITU & & 2.98 & 3.62 & 0.00 & $\mathrm{NCI} / \mathrm{M} 2$ & LASL 77 \\
\hline 2068 & RU 103 & 1977 & INSITU & & 9.30 & 5.02 & 0.00 & $\mathrm{NCI} / \mathrm{M2}$ & LASL 77 \\
\hline 2153 & RU 103 & 1977 & INS I TU & & 3.94 & 4.88 & 0.00 & NCI / M2 & LASL 77 \\
\hline 2027 & RU 103 & 1977 & INSITU & & 10.28 & 4.20 & .99 & $\mathrm{NCI} / \mathrm{ML}$ & LASL 77 \\
\hline 2018 & RU 103 & 1977 & INS I TU & & 6.66 & 1.76 & 0.00 & $\mathrm{NCI} / \mathrm{M} 2$ & LASL 77 \\
\hline 2094 & RU 103 & 1977 & INSITU & & 14.49 & 9.25 & 0.00 & $\mathrm{NCI} / \mathrm{M} 2$ & LASL 77 \\
\hline & RU 103 & 1977 & INSITU & & 7.07 & 2.04 & 0.00 & $N C^{T} / M=$ & LASL 77 \\
\hline
\end{tabular}


2042 RU 1031977 INSITU 2C34 RU103 1977 INSITU 2037 RU $103 \quad 1977$ INSITU 2127 RU $103 \quad 1977$ INSITU 2058 RU 103 197? INSITU 2154 RU103 1977 INSITU 2013 RU 1031977 INSITU 1998 RU 1031977 INSITU 2141 RU 1031977 INSITU 2130 RU 1031977 INSITU 2062 रं $103 \quad 1977$ INSITU 207 R R 1031977 INSITU 2067 RU103 1977 INSITU 2121 RU $103 \quad 1977$ INSITU 2084 RU 1031977 INSITU 2025 RU $103 \quad 1977$ INSITU 2065 RU $103 \quad 1977$ INSITU 2090 RU 1031977 INSITU 2047 RU $103 \quad 1977$ INSITU 2061 RU103 1977 INS:TU 2098 RU $103 \quad 1977$ INSITU 2048 RU $103 \quad 1977$ INSITU 2093 RU1O3 1977 INSITU 2128 RU $103 \quad 1977$ INSITU 2076 RU $103 \quad 1977$ INSITU 2084 RU 103 i97\% INSITU 2131 RU 103 197; TNSITU 2129 RU1O3 1977 INS!TL 208 RU RO3 1977 INSITU 2043 RU1C3 $\$ 977$ INSITU 2071 RU 1031977 INSITU 2155 RL 1031977 INSITU 2143 RL 1031977 INSITU $2 ; 14$ RU 1031977 INSITU 2030 RU103 1977 INSITU 2100 RU 1031977 INSITU 2140 RU 1031977 INSITU 2060 RU103 1977 INSITU 2050 RU 1031977 INSITU 2040 RU103 1977 INS I TU 2138 RU103 1977 INSITU 2119 RU 1031977 INSITU 2049 RU103 1977 SG

2007 RU 1031977 SK 1987 RU 1031977 SK $20: 6$ RU103 1977 SK 1991 RU 1OJ 1977 SK 2045 RU 103 19:7 S: $203 \mathrm{~B}$ PU 103 1970 TH 2052 RU:OJ 19:7 UK 2018 SR9O 1977 GR 2D28 SR9O 1977 GR 2O48 SRSO 197\% GR 2019 SR9O 1977 OTHER 2052 SR9O 1977 OTHER 2018 SRGO 1977 SK 1995 SR9O 1977 SK 2018 SR9O 1.977 SDIL 2072 SR9O 1977 SOIL 2052 SR9O 1977 SOIL 2014 SR9O 197 SGIL 2016 SR9O 1977 SOIL 2016 SR9O 1977 jOIL 2073 SR9C 1977 SOIL 2052 SR9O 1977 SOIL 2121 SR9O 1977 SOIL $212:$ SR9O 1977 SOIL 2028 SRgN 1977 SOIL 2048 SR9O 1977 SOIL 2019 SR9O 1977 SUIL 2097 SR9P $19 / 7$ SOIL 2052 SR9O 1977 SOIL 2060 SR9O 1977 SOIL 2071 SR9O 1977 SOIL 2097 SR9O 1977 SOIL 2118 SP9O 1977 SOIL 2072 SR9O 1977 SOIL $2060 \leqq R 90 \quad 1977$ SOIL 2018 SR9O 1977 SCIL 2014 SR9O 1977 SOIL

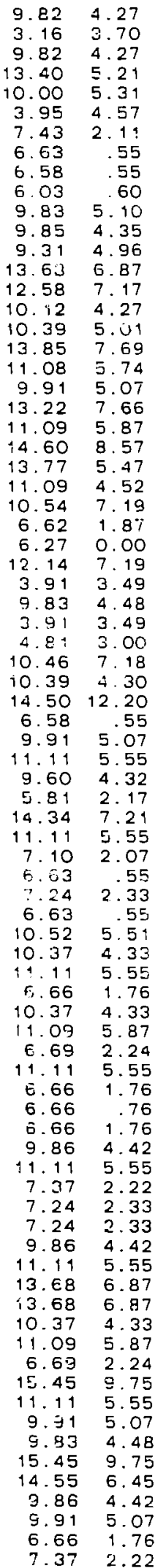

$0.00 \mathrm{NCI} / \mathrm{M} 2$ $0.00 \mathrm{NCI} / \mathrm{M} 2$ $0.00 \mathrm{NCI} / \mathrm{M} 2$ $0.00 \mathrm{NCI} / \mathrm{M} 2$ $0.00 \mathrm{NCI} / \mathrm{M} 2$ $0.00 \mathrm{NCI} / \mathrm{Mz}$ $0.00 \mathrm{NCI} / \mathrm{N}: 2$ $0.00 \mathrm{NCI} / \mathrm{M} 2$ $0.00 \mathrm{NCI}, \mathrm{M} 2$ $0.00 \mathrm{NCI} / \mathrm{M} 2$ $0.00 \mathrm{NCI} / \mathrm{M} 2$ $0.00 \mathrm{NCI} / \mathrm{M} 2$ $0.00 \mathrm{NCI} / \mathrm{M} 2$ $0.00 \mathrm{NCI} / \mathrm{M} 2$ $0.00 \mathrm{NCI} / \mathrm{M} 2$ $0.00 \mathrm{NCI} / \mathrm{M} 2$ $0.00 \mathrm{NCI} / \mathrm{M} 2$ $0.00 \mathrm{NCI} / \mathrm{M} 2$ $0.0 \mathrm{NCI} / \mathrm{N2}$ $0.00 \mathrm{iNCI} / \mathrm{M} 2$ $.94 \mathrm{NCI} / \mathrm{M} 2$ $1.02 \mathrm{NCI} / \mathrm{M} 2$ $0.00 \mathrm{NCI} / \mathrm{M} 2$ $0.00 \mathrm{NCI} / \mathrm{M} 2$ $0.00 \mathrm{NCI} / \mathrm{M} 2$ $0.00 \mathrm{NCI} / \mathrm{M} 2$ $0.00 \mathrm{NNCI} / \mathrm{M} 2$

$0.00 \mathrm{MCI} / \mathrm{M} 2$

$0.00 \mathrm{MLI} / \mathrm{M} 2$

$0.00 \mathrm{Ni} \mathrm{l} / \mathrm{M} 2$

$0.00 \mathrm{NI} / \mathrm{M} 2$ $83 \mathrm{NCI} / \mathrm{Mz}$

Q.CO NCI $/ \mathrm{Mz}$ $.95 \mathrm{NCI} / \mathrm{M} 2$ $0.00 \mathrm{NCI} / \mathrm{M} 2$ $0.00 \mathrm{NCI} / \mathrm{M} 2$ $0.00 \mathrm{NCI} / \mathrm{M} 2$

$0.00 \mathrm{NCI} / \mathrm{M} 2$

1. $12 \mathrm{NCI} / \mathrm{M} 2$

$0.00 \mathrm{NCI} / \mathrm{M2}$

$0.00 \mathrm{NCI} / \mathrm{M} 2$

$0.00 \mathrm{NCI} / \mathrm{M} 2$ $.50 \mathrm{PCI} / \mathrm{GM}$ 1. $17 \mathrm{PCI} / \mathrm{GM}$

$0.00 \mathrm{PCI} / \mathrm{GM}$

1. $06 \mathrm{PCI} / \mathrm{GM}$ $.35 \mathrm{PCI} / \mathrm{GM}$

$0.00 \mathrm{PCI} / \mathrm{G} / \mathrm{V}$

$0.00 \mathrm{PCI} / \mathrm{GM}$

$0.00 \mathrm{PCI} / \mathrm{GM}$

$50 \mathrm{PCI} / \mathrm{GM}$ $15 \mathrm{PCI} / \mathrm{GM}$

$.50 \mathrm{PCJ} / \mathrm{GM}$ 19 PCI GM 23 PCI, Gin

24 PCI/GM

$11 \mathrm{PCI} / \mathrm{GM}$ $50 \mathrm{PCI} / \mathrm{GM}$

$5.50 \mathrm{PCI} / \mathrm{GM}$ $22 \mathrm{PCI} / \mathrm{GM}$ $42 \mathrm{PCI} / \mathrm{GM}$

1.60 PCI/GM $37 \mathrm{PCI} / \mathrm{GM}$

6.80 FCI/GM $\% 6 \mathrm{PCI} / \mathrm{GM}$

$3.50 \mathrm{PCI} / \mathrm{GM}$

2. $16 \mathrm{PCI} / \mathrm{GM}$ $20 \mathrm{PCI} / \mathrm{GM}$ 30 PCI/GM $57 \mathrm{PCI} / \mathrm{GN}$ $88 \mathrm{PCI} / \mathrm{GM}$ O9 PCI/GM $.51 \mathrm{PCI} / \mathrm{GM}$

1. $65 \mathrm{PCI} / \mathrm{GM}$ $.21 \mathrm{PCI} / \mathrm{GM}$ $71 \mathrm{PCI} / \mathrm{GM}$ 1. $69 \mathrm{PCI} / \mathrm{GM}$ $1.32 \mathrm{PCI} / \mathrm{GM}$ . $10 \mathrm{PCI} / \mathrm{GM}$

$\triangle S$ L $^{-}$ ASL 7 LASL 7"

LASL $7^{\circ}$

LASL 7

LASL7?

LASL 7-

LASL7

LASL7?

LASL $7^{-}$

LASL77

LASL 77

LASL 77

LASL 77

LASL 77

LASL 77

LASL 77

.ASL 77

LASI 77

LASL. 77

LASL 77

LASL 77

LASL 77

LASL 77

LASL 77

LASL 77

L.ASL 77

LASL77

LASL 77

LASL 77

LASL 77

LASL 77

LASL77

LASL 77

LASL 77

LASL 77

LASL 77

LASL 77

LASL 77

LASL 77

LASL 77

LASL 77

LLL GELI

LLL GELI

LLL GELI

LLL GELI

LLL GELI

LLL GELI

LLI. GELI

LLL GELI

CVEG

CVEG

CVEG

C.VEG

CVEG

CVEG

LASLCHEM

LASLCHEM

LASLCHEM

LASLCHEM

LASLCHEM

LASLCHEM

LASLCHEM

LASLCHEM

LASLCHEM

LASI.CHEM

LASLCHEM

LASLCHEM

LASLCHEM

LASLCHEM

LASLCHEM

LASLCHEM

LASLCHEM

LASLCHEM

LASLCHEM

LASLCHEM

LASLCHEM

LASLCHEM 


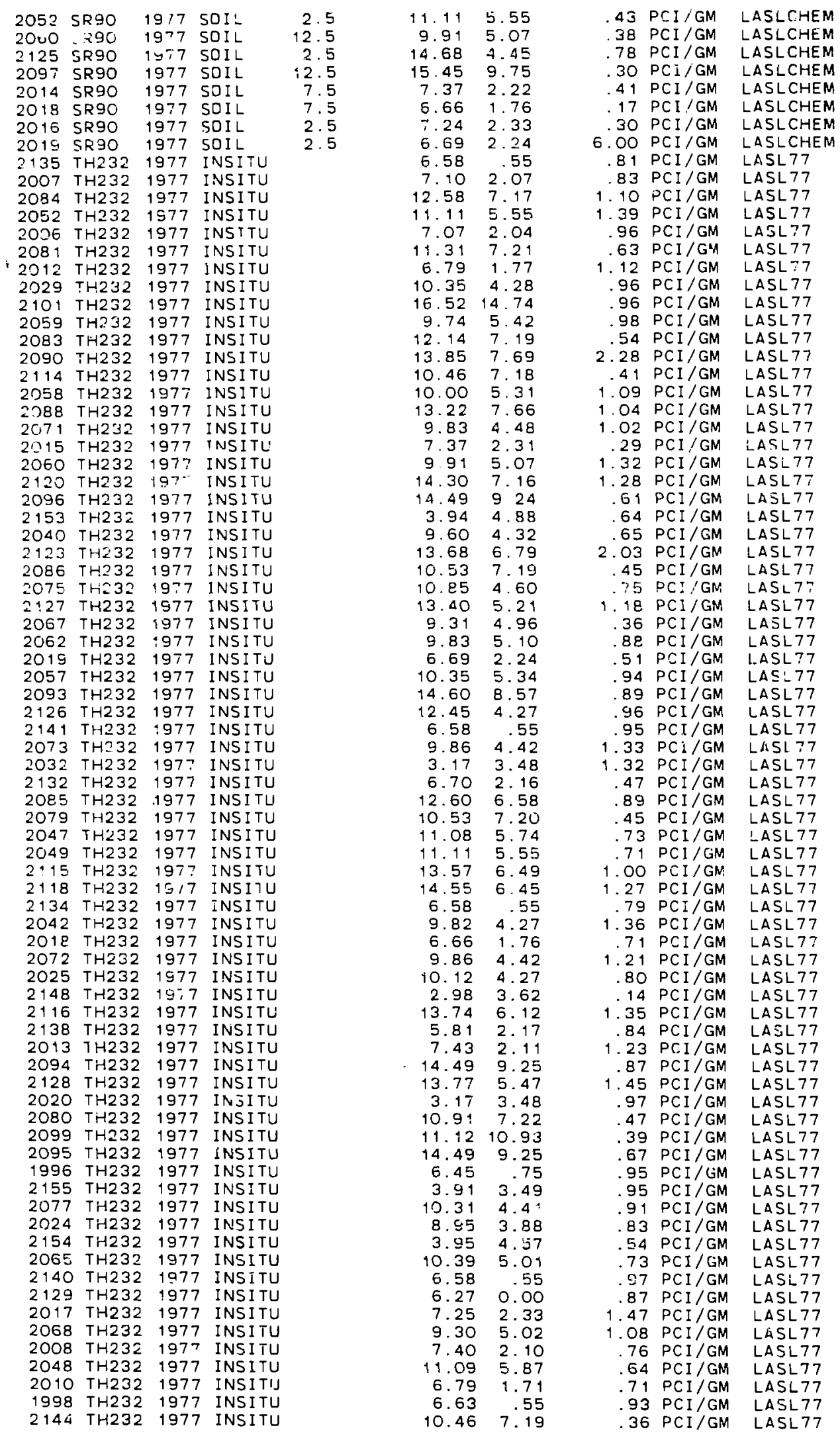




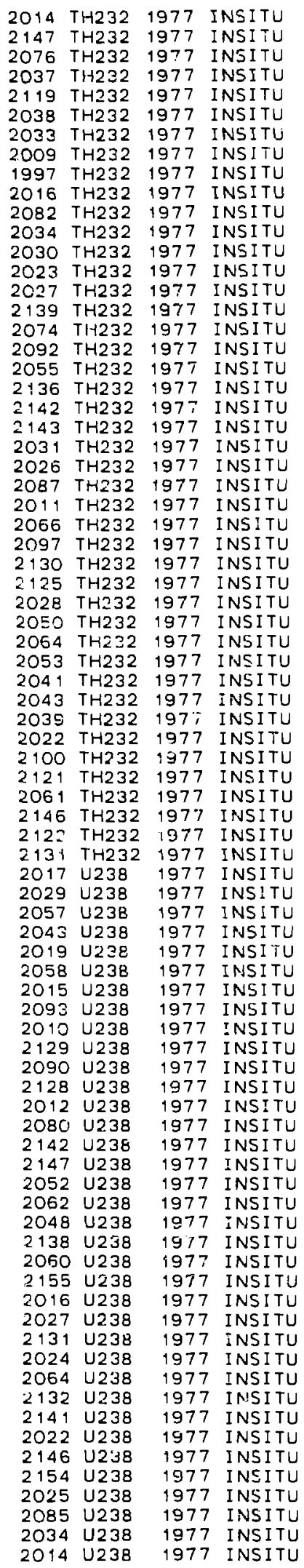

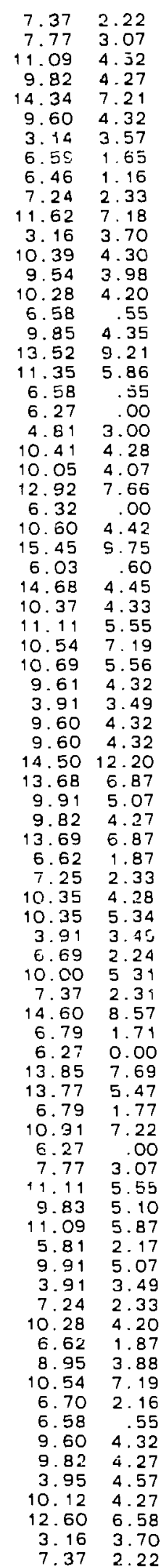

$1.82 \mathrm{HCI} / \mathrm{GM}$

$.64 \mathrm{PCI} / \mathrm{GM}$ $43 \mathrm{PCI} / \mathrm{GM}$

1.24 $\mathrm{PCI} / \mathrm{GM}$

$84 \mathrm{PCI} / \mathrm{GM}$

$64 \mathrm{PCI} / \mathrm{GM}$

$1.03 \mathrm{PCI} / \mathrm{GM}$

1. $39 \mathrm{PCI} / \mathrm{GM}$

$50 \mathrm{PCI} / \mathrm{GM}$

1. $22 \mathrm{PCI} / \mathrm{GM}$

1. $09 \mathrm{PCI} / \mathrm{GM}$

1. $15 \mathrm{PCI} / \mathrm{GM}$

$1.11 \mathrm{PCI} / \mathrm{GM}$

$1.00 \mathrm{PCI} / \mathrm{GM}$

$.47 \mathrm{PCI} / \mathrm{GM}$

$.89 \mathrm{PCI} / \mathrm{GM}$

$.81 \mathrm{PCI} / \mathrm{GM}$

$.31 \mathrm{PCI} / \mathrm{GM}$

$.98 \mathrm{PCI} / \mathrm{GM}$

78 PCI/GM

$.79 \mathrm{PCI} / \mathrm{GM}$

$.71 \mathrm{PCI} / \mathrm{GM}$

.7B PCI/GM

1. $17 \mathrm{PCI} / \mathrm{GM}$

1. $19 \mathrm{PCI} / \mathrm{GM}$

1. OE PCI/GM

$1.22 \mathrm{PCI} / \mathrm{GM}$

$1.04 \mathrm{PCI} / \mathrm{GM}$

$1.52 \mathrm{PCI} / \mathrm{GM}$

$1.49 \mathrm{FEI} / \mathrm{GM}$

1. OB PCI/GM

$.67 \mathrm{PCI} / \mathrm{GM}$

$.46 \mathrm{PCI} / \mathrm{GM}$

$.49 \mathrm{PCI} / \mathrm{GM}$

. $44 \mathrm{PCI} / \mathrm{GM}$

$.69 \mathrm{PCI} / \mathrm{GM}$

$.68 \mathrm{PCI} / \mathrm{GM}$

$.98 \mathrm{PCI} / \mathrm{GM}$

1. $09 \mathrm{PCI} / \mathrm{GM}$

2. $80 \mathrm{PCI} / \mathrm{GM}$

$1.42 \mathrm{PCI} / \mathrm{GM}$

$45 \mathrm{PCI} / \mathrm{GM}$

$2.74 \mathrm{PCI} / \mathrm{GM}$

$.70 \mathrm{FCI} / \mathrm{GM}$

$\therefore 45 \mathrm{PCI} / \mathrm{GM}$

$82 \mathrm{PCI} / \mathrm{GM}$

$83 \mathrm{PCI} / \mathrm{GM}$

$1.01 \mathrm{PCI} / \mathrm{GM}$

$58 \mathrm{PCI} / \mathrm{GM}$

BS PCI/GM

$69 \mathrm{PCI} / \mathrm{GM}$

$85 \mathrm{PCI} / \mathrm{GM}$

$65 \mathrm{PCI} / \mathrm{GM}$

TE PCI/GM

1.29 PCI/GM

$1.06 \mathrm{PCI} / \mathrm{GM}$

$93 \mathrm{PCI} / \mathrm{GM}$

$69 \mathrm{PCI} / \mathrm{GM}$

$77 \mathrm{PCI} / \mathrm{GM}$

$.75 \mathrm{PCI} / \mathrm{GM}$

$93 \mathrm{PCI} / \mathrm{GM}$

$.85 \mathrm{PCI} / \mathrm{GM}$

$\because 41 \mathrm{PCI} / \mathrm{GM}$

$68 \mathrm{PCI} / \mathrm{GM}$

$82 \mathrm{PCI} / \mathrm{GM}$

$1.04 \mathrm{PCI} / \mathrm{GM}$

1. $15 \mathrm{PCI} / \mathrm{GM}$

$71 \mathrm{PCI} / \mathrm{GM}$

$6 \mathrm{BPCI} / \mathrm{GM}$

$1.81 \mathrm{PCI} / \mathrm{GM}$

$47 \mathrm{PCI} / \mathrm{GM}$

$.64 \mathrm{PCI} / \mathrm{GM}$

$.72 \mathrm{PCI} / \mathrm{GM}$

$.84 \mathrm{PCI} / \mathrm{GM}$

$.57 \mathrm{PCI} / \mathrm{GM}$

$67 \mathrm{PCI} / \mathrm{GM}$

$.91 \mathrm{PCI} / \mathrm{GM}$

$96 \mathrm{PCI} / \mathrm{GM}$

1. $11 \mathrm{PCi} / \mathrm{GM}$

1. $27 \mathrm{PCI} / \mathrm{GM}$

$\operatorname{LASL} 77$

LASL 77

LASL 77

LASL 77

LASL 77

LASL 77

LASL 77

LASL 77

LASL 77

LASL 77

LASL 77

LASL 77

LASL 77

LASL 77

LASL 77

LASL 77

LASL 77

LASL 77

LASL 77

LASL 77

LASL 77

LASL 77

LASL 77

LASL 77

LASL 77

LASL 77

LASL 77

LASL 77

LASL 77

LASL 77

LASL 77

LASL 77

LASL 77

LASL 77

LASL 77

LASL 77

LASL 77

LASL 77

LASL 77

LASL 77

LASL 77

LASL 77

LASL 77

LASL 77

LASL 77

LASL 77

LASL 77

LASL 77

LASL 77

LASL 77

LASL 77

LASL 77

LASL77

LASL 77

LASL 77

LASL 77

LASL 77

LASL 77

LASL 77

LASL 77

LASL 77

LASL 77

LASL 77

LASL 77

LASL 77

LASL 77

LASL 77

LASL 77

LASL 77

LASL 77

LASL 77

1: $\mathrm{SL77}$

- 5477

LASL 77

LASL 77

LASL 77

LASL77

LASL 77

LASL 77

LASL 77 


\begin{tabular}{|c|c|c|c|c|c|c|c|c|}
\hline $\begin{array}{l}2071 \\
2028\end{array}$ & $\begin{array}{l}\text { U } 238 \\
\text { U238 }\end{array}$ & $\begin{array}{l}1977 \\
1977\end{array}$ & $\begin{array}{l}\text { INSITU } \\
\text { INSITU }\end{array}$ & $\begin{array}{r}9.83 \\
10.37\end{array}$ & $\begin{array}{l}4.48 \\
4.33\end{array}$ & $\begin{array}{l}.96 \\
.90\end{array}$ & $\begin{array}{l}\mathrm{PCI} / \mathrm{GM} \\
\mathrm{PCI} / \mathrm{GM}\end{array}$ & $\begin{array}{l}\text { L.ASL } 77 \\
\text { LASL } 77\end{array}$ \\
\hline 2032 & บ238 & 1977 & INS I TU & 3. 17 & 3.48 & 1. 11 & $\mathrm{PCI} / \mathrm{GM}$ & LASL 77 \\
\hline 2127 & บ238 & 1977 & INSITU & 13.40 & 5.21 & .93 & PCI / GM & LASL 77 \\
\hline 2086 & บ238 & 1977 & INS I TU & 10.53 & 7.19 & 43 & $\mathrm{PCI} / \mathrm{GM}$ & LASL 77 \\
\hline 2049 & บ238 & 1977 & INS I TU & 11.11 & 5.55 & 71 & $\mathrm{PCI} / \mathrm{GM}$ & LASL 77 \\
\hline 2009 & U238 & 1977 & INSITU & 11.12 & $1 n 93$ & .51 & $\mathrm{PCI} / \mathrm{GM}$ & LASL 7 ? \\
\hline 2130 & 1238 & 1977 & INSITU & 6.03 & .50 & 1.23 & $\mathrm{PCI} / \mathrm{GN}$ & LASL 77 \\
\hline 2095 & บ238 & 1977 & INS I TU & 14.49 & 9.25 & .63 & $P C I / G M$ & LASL 77 \\
\hline $204 ?$ & U238 & 1977 & INSITU & 11.09 & 5.74 & 1.54 & $\mathrm{~F}=\mathrm{I} / \mathrm{GM}$ & $\operatorname{2SSL77}$ \\
\hline 2118 & U238 & 1977 & INSITU & 14.55 & 6.45 & .96 & $\mathrm{PCI} / \mathrm{GM}$ & LASL 77 \\
\hline 2148 & U238 & 1977 & INS ITU & 2.98 & 3.62 & 96 & $\mathrm{PCI} / \mathrm{GM}$ & LASL 77 \\
\hline 2068 & บ238 & 1977 & INS ITU & 9.30 & 5.02 & 96 & $\mathrm{PCI} / \mathrm{GM}$ & LASL 77 \\
\hline 2077 & บ238 & 1977 & I NS I TU & 10.31 & 4.49 & .91 & $\mathrm{PC} 1 / \mathrm{GM}$ & LASL 77 \\
\hline 2084 & $\cup 238$ & 1977 & I NS I TU & 12.58 & 7.17 & .93 & $\mathrm{PCI} / \mathrm{GM}$ & LASL77 \\
\hline 2011 & บ238 & 1977 & INSITU & 6.32 & .00 & .89 & $\mathrm{PCI} / \mathrm{GM}$ & LASL 77 \\
\hline 2007 & U238 & 1977 & INS I TU & 7.10 & 2.07 & .75 & $\mathrm{PCI}, \mathrm{GM}$ & LASL 77 \\
\hline 2088 & บ238 & 1977 & INSI TU & 13.22 & 7.66 & 1.71 & $\mathrm{PCI} / \mathrm{GM}$ & LASL 77 \\
\hline 2092 & บ238 & 1977 & INSI TU & 13.52 & 9.21 & .43 & $P C I / G M$ & LASL 77 \\
\hline 2139 & บ238 & 1977 & INSITU & 6.58 & .55 & .65 & $\mathrm{PCI} / \mathrm{GM}$ & LASL 77 \\
\hline 2039 & U238 & 1977 & INSITU & 9.60 & 4. 32 & 1.04 & $\mathrm{PCI} / \mathrm{GM}$ & LASL 77 \\
\hline 2038 & U238 & 1977 & INS I TU & 9.60 & 4.32 & 1.05 & $P \subset I / G M$ & LASL 77 \\
\hline 2121 & U238 & 1977 & INS I TU & 13.68 & 6.87 & 1. 17 & $\mathrm{PCI} / \mathrm{GM}$ & LASL 77 \\
\hline 2037 & U238 & 1977 & INS I TU & 9.82 & 4.27 & 1.02 & $\mathrm{PCI} / \mathrm{GM}$ & LAS 777 \\
\hline 2031 & U238 & 1977 & INS I TU & 10.41 & 4. 28 & .75 & $P C I / G M$ & LASL .7 \\
\hline 2136 & 4238 & 1977 & INS I TU & 6.58 & .55 & 56 & $\mathrm{PCI} / \mathrm{GM}$ & LASL 77 \\
\hline 2076 & U238 & 1977 & INSITU & 11.09 & 4.52 & .71 & $\mathrm{PCI} / \mathrm{GM}$ & LASL 77 \\
\hline 2041 & U2 38 & 1977 & INS I TU & 9.61 & 4.32 & 1.01 & $\mathrm{PCI} / \mathrm{GM}$ & LASL 77 \\
\hline 2087 & $\cup 238$ & 1977 & INS I TU & 12.92 & 7.66 & .93 & $\mathrm{PCI} / \mathrm{GM}$ & LASL 77 \\
\hline 2125 & บ238 & 197 & INS I TU & 14.68 & 4.45 & 1.18 & $\mathrm{PCI} / \mathrm{GM}$ & LASL 77 \\
\hline 2096 & U238 & $197^{\circ}$ & I NS I TU & 14.49 & 9.24 & .78 & PCI / GM & LASL 77 \\
\hline 2115 & U238 & 1977 & I NS I TU & 13.57 & 6.49 & .95 & $P C I / G M$ & LASL 77 \\
\hline 2082 & $U: 38$ & 1977 & I"NSITU & 11.62 & 7.18 & .88 & $\mathrm{PCI} / \mathrm{GM}$ & LASL 77 \\
\hline 2119 & $\cup 238$ & $: 977$ & INSITU & 14.34 & 7.21 & 68 & PCI / GM & LASL 77 \\
\hline 2008 & U238 & 1977 & INSITL & 7.40 & 2.10 & 83 & $\mathrm{PCI} / \mathrm{GM}$ & LASL 77 \\
\hline 2026 & U238 & 1977 & INSITU & 10.05 & 4.07 & 96 & $P C I / G M$ & LASL 77 \\
\hline 2094 & U238 & 1977 & INS I TU & 14.49 & 9.25 & 73 & $\mathrm{PCI} / \mathrm{GM}$ & LASL7T \\
\hline 2123 & 1238 & 1977 & INS I TU & 13.68 & 6.79 & .98 & $\mathrm{PCI} / \mathrm{GM}$ & LASL 77 \\
\hline 2122 & U238 & 1977 & INSITU & 13.69 & 6.87 & 1.39 & $P C I / G M$ & LASL 77 \\
\hline 2013 & U238 & 1977 & INSTTU & 7.43 & 2.11 & .98 & $\mathrm{PCI} / \mathrm{GM}$ & LASL 77 \\
\hline 2120 & U238 & $19^{-7}$ & INS I TU & 14.30 & 7.16 & 92 & $\mathrm{PCI} / \mathrm{GM}$ & LASL 77 \\
\hline 2067 & U238 & 1977 & INS I TU & 9.31 & 4.96 & 75 & $\mathrm{PCI} / \mathrm{GM}$ & LASL 77 \\
\hline 1998 & บ238 & 1977 & INS I TU & 6.53 & .55 & .89 & $\mathrm{PCI} / \mathrm{GM}$ & LASL 77 \\
\hline 2009 & บ238 & 1977 & INS I TU & 6.59 & 1.65 & 1.20 & $\mathrm{PCI} / \mathrm{GM}$ & LASL 77 \\
\hline 2079 & U238 & 1977 & INSITU & 10.53 & 7.20 & .68 & $\mathrm{PCI} / \mathrm{GM}$ & LASL 77 \\
\hline 2381 & บ238 & 1977 & INS I TU & -1.31 & 7.21 & .77 & $\mathrm{PCI} / \mathrm{GM}$ & LASL 77 \\
\hline 2116 & 11238 & 1977 & I NS I TU & 13.74 & 6.12 & 1.00 & $\mathrm{PCI} / \mathrm{GM}$ & LASL 77 \\
\hline 2153 & บ238 & 1977 & INSITU & 3.94 & 4. $8 \therefore$ & 9.31 & $\mathrm{PCI} ; \mathrm{GM}$ & $\triangle 4 S\llcorner 77$ \\
\hline 2140 & $\cup 238$ & 1977 & INS I TU & 5.58 & .55 & .77 & $\mathrm{PCI} / \mathrm{GM}$ & LASL 77 \\
\hline 2083 & บ238 & 1977 & INS I TU & 12.14 & 7.19 & .79 & $P C I / G M$ & LASL 77 \\
\hline 2101 & $\cup 238$ & 1977 & INSITU & 16.52 & 14.74 & .81 & $\mathrm{PCI} / \mathrm{GM}$ & LASL77, \\
\hline 2023 & U238 & 1977 & INS I TU & 9.54 & 3.98 & 1.08 & $\mathrm{PCl} / \mathrm{GM}$ & LASL 77 \\
\hline 2100 & U238 & 1977 & INSITU & 14.50 & 12.20 & 1.02 & $\mathrm{PCI} / \mathrm{GM}$ & LASL 77 \\
\hline 2059 & U238 & 1977 & INS I TU & 9.74 & 5.42 & .96 & $\mathrm{PCI} / \mathrm{GM}$ & LASL 77 \\
\hline 2030 & U238 & 1977 & INSI TL & 10.39 & 4.30 & .88 & $\mathrm{PCI} / \mathrm{GM}$ & LASL 77 \\
\hline 2097 & U238 & 1977 & INS I TU & 15.45 & 9.75 & 1.03 & $\mathrm{PCI} / \mathrm{GM}$ & LASL 77 \\
\hline 1997 & U238 & 1977 & INS I TL & 0. 46 & 1.16 & .48 & $\mathrm{PCI} / \mathrm{GM}$ & LASL 77 \\
\hline 2074 & U238 & 1977 & INSI TU & 9.85 & 4.35 & .94 & $\mathrm{PCI} / \mathrm{GM}$ & LASL 77 \\
\hline 2061 & ป238 & 1977 & INSITU & 9.91 & 5.07 & .89 & $\mathrm{PCI} / \mathrm{GM}$ & LASL 77 \\
\hline 2042 & U238 & 1977 & INSITU & 9.82 & 4.27 & 1.02 & $\mathrm{PCI} / \mathrm{GM}$ & LASL 77 \\
\hline 2055 & U238 & 1977 & INS I TU & 11.35 & 5.86 & .73 & $\mathrm{PCI} / \mathrm{GM}$ & LASL 77 \\
\hline 2114 & ن238 & 1977 & INS I TU & 10.46 & 7.1 .9 & .54 & $\mathrm{PCI} / \mathrm{GM}$ & LASL 77 \\
\hline 2072 & U238 & 1977 & INSITU & 9.86 & 4.42 & .95 & $\mathrm{PCI} / \mathrm{GM}$ & LASL 77 \\
\hline 2065 & 4238 & 1977 & INS I TU & 10.39 & 5.01 & .91 & PC I / GM & LASL 77 \\
\hline 2018 & U238 & 1977 & INS I TU & 6.66 & 1.76 & $.7 \ddagger$ & $\mathrm{PCI} / \mathrm{GM}$ & LASL 77 \\
\hline 2040 & U238 & 1977 & INSITU & 9.60 & 4.32 & 1.02 & $\mathrm{PCI} / \mathrm{GM}$ & LASL 77 \\
\hline 2053 & 4238 & 1977 & INS I TU & 10.69 & 5.56 & .80 & $\mathrm{PCI} / \mathrm{GM}$ & LASL 77 \\
\hline 2135 & U238 & 1977 & INS I TU & 6.58 & .55 & 0.00 & $P C I / G M$ & LASL 77 \\
\hline 2144 & U238 & 1977 & INSITU & 10.46 & 7.19 & .34 & $\mathrm{PCI} / \mathrm{GM}$ & LASL 77 \\
\hline 2020 & U238 & 1977 & I NS I TU & 3. 17 & 3.48 & 2.04 & $\mathrm{PCI} / \mathrm{GM}$ & LASL 77 \\
\hline 2006 & 11238 & 1977 & I NS I TU & 7.07 & 2.04 & 1.02 & $\mathrm{PCI} / \mathrm{GM}$ & LASL 77 \\
\hline 2056 & U238 & 1977 & INS, IU & 10.60 & 4.42 & .91 & $\mathrm{PCI} / \mathrm{GM}$ & LASL 77 \\
\hline 2073 & U238 & 1977 & I NS I TU & 9.86 & 4.42 & 1.05 & $P C I / G M$ & LASL 77 \\
\hline 2134 & U238 & 1977 & INS I TU & 6.58 & .55 & .88 & $\mathrm{PCI} / \mathrm{GM}$ & LASL 77 \\
\hline 2143 & U238 & 1977 & INS I TU & 4.81 & 3.00 & .85 & $\mathrm{PCI} / \mathrm{GM}$ & LASL 77 \\
\hline $212 \bar{G}$ & U238 & 1977 & INS I TU & 12.45 & 4.27 & .83 & $\mathrm{PCI} / \mathrm{GM}$ & LASL 77 \\
\hline 2.933 & U238 & 1977 & INSITU & 3.14 & 3.57 & 1.34 & $\mathrm{PCI} / \mathrm{GM}$ & LASL 77 \\
\hline 2050 & U238 & 1977 & INS I TU & 11.11 & 5.55 & .72 & $\mathrm{PCI} / \mathrm{GM}$ & LASL 77 \\
\hline 2075 & $\cup 238$ & 1977 & INS I TU & 10.85 & 4.60 & .71 & PCI / GM & LASL 77 \\
\hline 1996 & $U<38$ & $197 ?$ & I NS I TU & 6.45 & .75 & .93 & $\mathrm{PCI} / \mathrm{GM}$ & LASL 77 \\
\hline
\end{tabular}




\begin{tabular}{|c|c|c|c|c|c|c|c|c|}
\hline 2055 & ZR95 & 1977 & GR & 11.35 & 5.86 & 5.80 & PCI / GM & LI.L \\
\hline 1990 & ZR95 & 1977 & GR & 6.64 & .55 & 2.99 & $\mathrm{PCI} / \mathrm{GM}$ & $L L L \quad G E$ \\
\hline 2018 & ZR95 & 1977 & GR & 6.66 & 1.76 & 3.54 & $\mathrm{PCI} / \mathrm{GM}$ & LLL GEL \\
\hline 1988 & ZR95 & 1977 & GR & 6.64 & .55 & 2.33 & $\mathrm{PCI} / \mathrm{GM}$ & LLL GE \\
\hline 2140 & ZR95 & 1977 & INS I TU & 6.58 & .55 & 0.00 & $N \subset 1 / M 2$ & LASL 77 \\
\hline 2024 & ZR95 & 1977 & INS I TU & 8.95 & 3.88 & 2.58 & $\mathrm{NCI} / \mathrm{M} 2$ & $\operatorname{LSSL} 77$ \\
\hline 2019 & ZR95 & 1977 & INSITU & 6.69 & 2.24 & 2.37 & $\mathrm{NCI} / \mathrm{M2}$ & LASL 77 \\
\hline 2093 & 2R95 & 1977 & INSITU & 14.60 & 8. 57 & 2.75 & $\mathrm{NCI} / \mathrm{M} 2$ & LASLT7 \\
\hline 2097 & ZR95 & 1977 & INSITU & 15.45 & 9.75 & 3.05 & $\mathrm{NCI} / \mathrm{M} 2$ & LASL 77 \\
\hline 2022 & ZR95 & 1977 & INSITU & 9.60 & 432 & 2.88 & $N C I / M 2$ & LASL 77 \\
\hline 2028 & 2R95 & 1977 & INS I TL & 10.37 & 4.33 & 3.41 & $\mathrm{NCI} / \mathrm{M} 2$ & LASL77 \\
\hline 2039 & ZR95 & 1977 & INS I TU & 9.60 & 4.32 & 1.57 & $\mathrm{NCI} / \mathrm{M} 2$ & LASL 77 \\
\hline 2047 & ZR95 & 1977 & INS I TU & 11.08 & 5.74 & 3.33 & $\mathrm{NCI} / \mathrm{M} 2$ & LASL 77 \\
\hline 2138 & ZR95 & 1977 & INS I TU & 5.81 & 2.17 & 5.04 & $\mathrm{NCI} / \mathrm{M} 2$ & LASL 77 \\
\hline 2081 & ZR95 & 1977 & INS I TU & 11.31 & 7.21 & 2.86 & $\mathrm{NCI} / \mathrm{M} 2$ & LASL 77 \\
\hline 2076 & ZR95 & 1977 & INS I TU & 11.09 & 4.52 & 2.74 & $\mathrm{NCI} / \mathrm{M} 2$ & LASL 77 \\
\hline 2119 & 2R95 & 1977 & I NSI TU & 14.34 & 7.21 & 3.57 & $\mathrm{NCI} / \mathrm{M} 2$ & LASL 77 \\
\hline 2094 & ZR95 & 1977 & INSI TU & 14.49 & 9.25 & 2.79 & $\mathrm{NCI} / \mathrm{M} 2$ & LASL 77 \\
\hline 2017 & ZR95 & 1977 & INS I TU & 7.25 & 2.33 & 2.86 & $\mathrm{NCI} / \mathrm{M} 2$ & LASL 77 \\
\hline 2096 & 2R95 & 1977 & INSI TU & 14.49 & 9.24 & 2.56 & $\mathrm{NCI} / \mathrm{M} 2$ & LASL 77 \\
\hline 2118 & ZR95 & 1977 & I NSI I U & 14.55 & 6.45 & 3. 16 & $\mathrm{NCI} / \mathrm{M} 2$ & $L A S L 77$ \\
\hline 2087 & 2R95 & 1977 & INSI TU & 12.92 & 7.66 & 2.84 & $\mathrm{NICI} / \mathrm{M2}$ & LASL 77 \\
\hline 2052 & 2R95 & 1977 & I NS I TU & 11.11 & 5.55 & 3.12 & $\mathrm{NCl} / \mathrm{M} 2$ & LASL 77 \\
\hline 2059 & ZR95 & 1977 & INS I TU & 9.74 & 5.42 & 2.30 & $N C I / M 2$ & LASL 77 \\
\hline 2123 & 2R95 & 1977 & INS I TU & 14.63 & 4. 45 & 3.24 & $\mathrm{NCI} / \mathrm{M} 2$ & LASL 77 \\
\hline 2086 & 2RAS & 1977 & INS I TU & 10.53 & 7.19 & 2.27 & NCI'M2 & LASL 77 \\
\hline 2088 & ZR95 & 1977 & INSITU & 13.22 & 7.66 & 5.82 & $\mathrm{NCI} / \mathrm{M} 2$ & LASL 77 \\
\hline 2010 & ZR95 & 1977 & INS I TU & 6.79 & 1.71 & 2.57 & $\mathrm{NCI} / \mathrm{ML}_{2}$ & LASL 77 \\
\hline 2037 & 2R95 & 1977 & INS I TU & 9.82 & 4.27 & 3.28 & $\mathrm{NCI} / \mathrm{M} 2$ & LASL 77 \\
\hline 2143 & ZR95 & 1977 & INS I TU & 4.81 & 3.00 & 0.00 & NCI / M2 & LASL 77 \\
\hline 2134 & 2R95 & 1977 & INS!TU & 6.58 & .55 & 0.00 & $\mathrm{NCI} / \mathrm{M} 2$ & LASL 77 \\
\hline 2061 & 2R95 & 1977 & I NS I TU & 9.91 & 5.07 & 2.90 & $N C I / M_{2}$ & LASL 77 \\
\hline 2023 & ZR95 & 1977 & INSITL & 9.54 & 3.98 & 2.74 & $N C I: N_{2} 2$ & LASL 77 \\
\hline 2121 & ZR95 & 1977 & INSITU & 13.68 & 6.87 & 2.95 & $\mathrm{NCI} / \mathrm{M} 2$ & LASL 77 \\
\hline 2080 & 2R95 & 1977 & INSITU & 10.91 & 7.22 & 2.98 & NCI / M2 & LASL 77 \\
\hline 2073 & ZR95 & 1977 & INSITU & 9.86 & 4.42 & 3. 19 & $\mathrm{NCI} / \mathrm{M} 2$ & LASL.77 \\
\hline 2042 & ZR95 & 1977 & INSITU & 9.82 & 4.27 & 3.02 & $\mathrm{NC}: / \mathrm{M} 2$ & LASL 77 \\
\hline 2083 & 2R95 & 1977 & INS I TU & 12.14 & 7.19 & 2.42 & $\mathrm{NCI} / \mathrm{M} 2$ & LASL 77 \\
\hline 2033 & ZR95 & 1977 & I NS I TU & 3.14 & 3.57 & 1.45 & NC I / M2 & LASL 77 \\
\hline 1997 & ZRO5 & 1977 & INS I TU & 6.46 & 1.16 & 1.01 & $\mathrm{NCI} / \mathrm{M} 2$ & $L \Delta S\llcorner 77$ \\
\hline 2074 & ZR95 & 1977 & INSITU & 9.85 & 4.35 & 2.21 & $N C I / M 2$ & LASL 77 \\
\hline $212 \Xi$ & 2R95 & 1977 & INS I TU & 13.68 & 6.79 & 0.00 & NCI / M2 & LASL 77 \\
\hline 2095 & ZR95 & 1977 & INS I TU & 14.49 & 9.25 & 2.17 & $\mathrm{NCI} / \mathrm{M} 2$ & LASL 77 \\
\hline 2147 & ZR95 & 1977 & INEITU & 7.77 & 3.07 & 0.00 & $N C I / M 2$ & LS.SL 77 \\
\hline 1996 & ZR95 & $19: 7$ & INS I TU & 6.45 & .75 & 3.04 & NCI / M2 & LASL 77 \\
\hline 2049 & ZR95 & 1977 & I NEI TU & : 1.11 & 5.55 & 3.05 & $N C I / M 2$ & LASL :7 \\
\hline 2057 & $2 R 95$ & 1977 & INSITU & $10 \quad 35$ & 5.34 & 3.32 & $\mathrm{NCI} / \mathrm{M2}$ & LASL 77 \\
\hline 2040 & 2R95 & 1977 & INS:TU & 9.60 & 1. 32 & 3.12 & $\mathrm{NCI} / \mathrm{MZ}$ & LASL 77 \\
\hline 2072 & ZR95 & 1977 & INSITU & 9.86 & 4.42 & 3.32 & $\mathrm{~N}=1 / \mathrm{M} 2$ & LASL 77 \\
\hline 2026 & 2P.95 & 1977 & INS ITU & 10.05 & $4.0^{-}$ & 2.99 & $\mathrm{NCI} / \mathrm{M2}$ & $\angle A S L 77$ \\
\hline 2065 & ZR95 & 1977 & INSITU & 10.39 & 5.01 & 0.00 & NCI / M2 & LASL 77 \\
\hline 2011 & ZR95 & 1977 & I NS I TU & 6.32 & .00 & 2.44 & NCI / M2 & LASL 77 \\
\hline 2122 & ZR95 & 1977 & INS I TU & 13.69 & 6.87 & 3.32 & NCI / M2 & LASL7T \\
\hline 2013 & ZR95 & $: 977$ & INSI TU & 7.43 & 2.11 & 2.46 & $\mathrm{NCI} / \mathrm{M} 2$ & LASL 77 \\
\hline 2136 & 2R95 & 1977 & INSITU & $\epsilon .5 \mathrm{~g}$ & .55 & 0.00 & $\mathrm{NCI} / \mathrm{M} 2$ & $\angle \triangle S L 77$ \\
\hline 2155 & ZR95 & 1977 & INS I TU & 3.91 & 3.49 & 2.62 & $\mathrm{NCI} / \mathrm{M} 2$ & LASL 77 \\
\hline 2092 & 2R95 & 1977 & INSITU & 13.52 & 9.21 & 2.56 & $\mathrm{NCI} / \mathrm{M} 2$ & LASL 77 \\
\hline 2016 & 2R95 & 1977 & INS I TU & 7.24 & 2.33 & $3.7 \bar{\varepsilon}$ & $\mathrm{NCI} / \mathrm{M} 2$ & LASL 77 \\
\hline 2029 & ZR95 & 1977 & INS I TU & 10.35 & 4.28 & 4. 11 & NC I / M2 & LASL 77 \\
\hline 2130 & 2R95 & 1977 & INSI IU & $6 . \cup 3$ & .60 & 0.00 & $\mathrm{NCI} / \mathrm{M} 2$ & L $\triangle S L 77$ \\
\hline 2077 & 2R95 & 1977 & INSITU & 10.31 & 4.41 & 3.38 & $\mathrm{NCI} / \mathrm{M} 2$ & LASL 77 \\
\hline 2038 & 2R95 & 1977 & INSI TU & 9.60 & 4.32 & 2.33 & $\mathrm{NCI} / \mathrm{M} 2$ & LASL 77 \\
\hline 2067 & 2R95 & 1977 & INSITU & 9.31 & 4.96 & 0.00 & NCI / M2 & LASL 77 \\
\hline 2100 & 2R95 & 1977 & INS I TU & 14.50 & 12.20 & 2.76 & $\mathrm{NCI} / \mathrm{M} 2$ & LASL 77 \\
\hline 2101 & 2R95 & 1977 & INSITU & 16.52 & 14.74 & 3.78 & $\mathrm{NCI} / \mathrm{M} 2$ & LASL 77 \\
\hline 2060 & 2R95 & 1977 & INSITU & 9.91 & 5.01 & 2.39 & NCI / M2 & LASL 77 \\
\hline 2144 & 2R95 & 1977 & INSITU & 10.46 & 7. 19 & 1.52 & $\mathrm{NCI} / \mathrm{M} 2$ & LASL77 \\
\hline 2034 & ZR95 & 1977 & INS ITU & 3.16 & 3.70 & 2.41 & $\mathrm{NCI} / \mathrm{M} 2$ & L.AS'.77 \\
\hline 2127 & ZR95 & 1977 & INS I TU & 13.40 & 5.21 & 2.56 & NCI / M2 & LASL 77 \\
\hline 2129 & ZR95 & 1977 & INSITU & 6.27 & 0.00 & 1.78 & NC I / M2 & LASL 77 \\
\hline 2012 & 2R95 & 1977 & INS I TU & 6.79 & 1.77 & 3.22 & NCI / M2 & LA.SL 77 \\
\hline 2154 & ZR95 & 1977 & INSITU & 3.95 & 457 & 1.36 & $\mathrm{NCI} / \mathrm{M} 2$ & LASL 77 \\
\hline 2128 & ZR 95 & 1977 & INS I TU & 13.77 & 5.47 & 2. 12 & INC I / M2 & LASL 77 \\
\hline 2114 & 2R95 & 1977 & LNS I TU & 10.46 & 7.18 & 0.00 & $\mathrm{NCI} / \mathrm{M} 2$ & LASL 77 \\
\hline 2025 & ZR95 & 1977 & INSITU & 10.12 & 4.27 & 2.89 & NC I / M2 & LASL 77 \\
\hline 2018 & ZR95 & 1977 & INS I TU & 6.66 & 1.76 & 3.05 & $\mathrm{NCI} / \mathrm{Mz}$ & LลSL77 \\
\hline 2068 & ZR95 & 1977 & INS I TU & 9.30 & 5.02 & 3.53 & $\mathrm{NCI} / \mathrm{M} 2$ & LASL 77 \\
\hline 2015 & ZR95 & 1977 & INS I TU & 7.37 & 2.31 & 2.22 & NCI / M2 & LASL 77 \\
\hline 2075 & ZR95 & 1977 & INS I TU & 10.85 & 4.60 & 2.09 & $N C I / M 2$ & LASL 77 \\
\hline 2064 & ZR95 & 1977 & INSITU & 10.54 & 7.19 & 2.42 & $\mathrm{NCI} / \mathrm{M} 2$ & LASL 77 \\
\hline
\end{tabular}




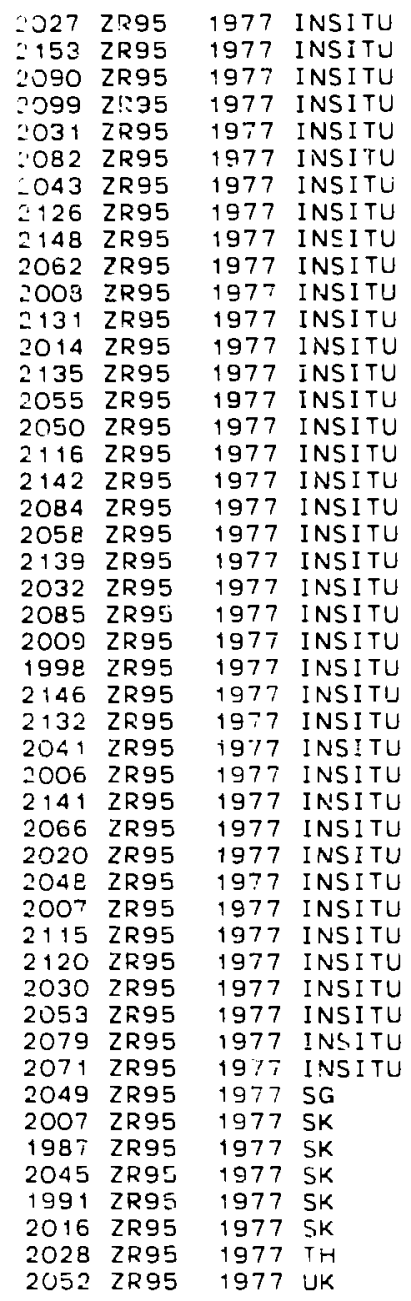

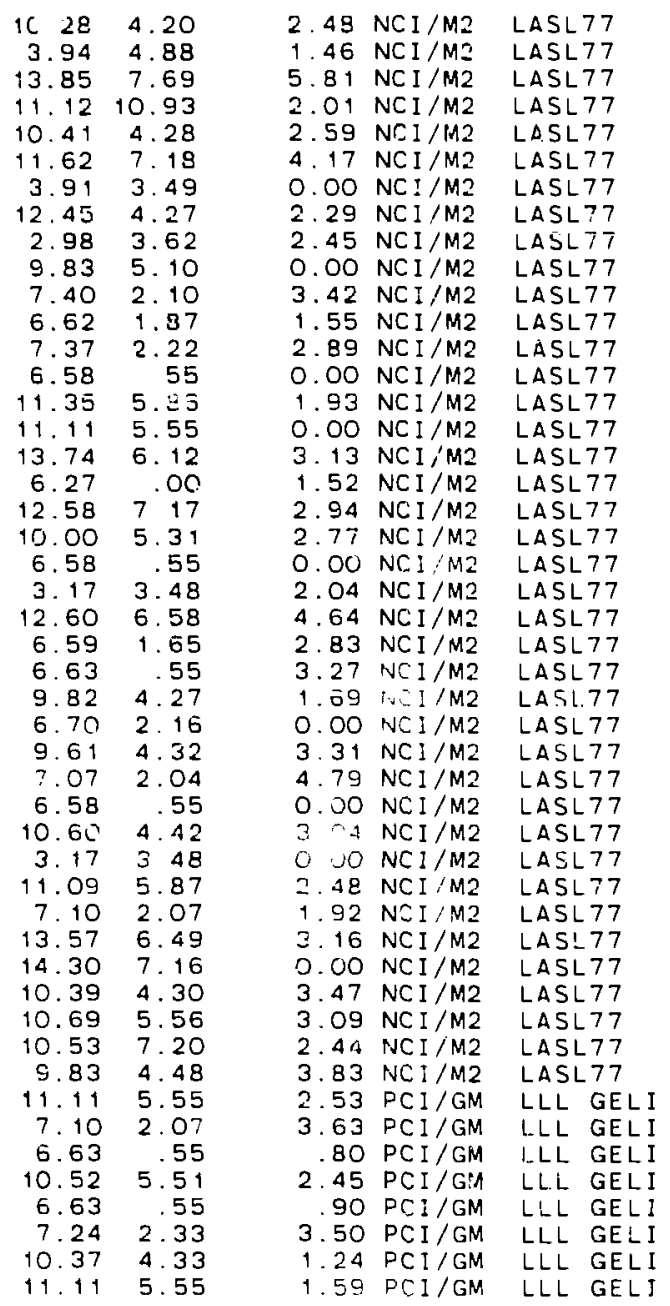




\section{APPENDIX B}

\section{LOG OF FIELD OPERATIONS FOR SURVEY OF TRINITY, 1977}

During the survey of the Trinity fallout zone, each sample location was marked with a wooden stake with a brass tag attached. The number corresponding to the data "tag word" was stamped on the brass tag. The locations were noted on topographical maps of the area and in field notevooks. These documents will be kept in a master file with the Los Alamos National Laboratory Environmental Surveillance Group. Tag words that are not in the following list represtnt calibration checks or measurements at locations outside the Trinity fallout zone.

$19856 / 20 / 77$; background spectrum taken with planar $\mathrm{Ge}(\mathrm{Li})$ at Los Alamos National Laboratory control plot $\sim 3$ miles south of $\mathrm{GZ}$.

1986 6/20/77; inside GZ inner fence. Planar Ge(Li).

$19876 / 20 / 77$; inside $\mathrm{GZ}$ inner fence, $13 \mathrm{~m}$ from fence northeast of monument. Planar $\mathrm{Ge}(\mathrm{Li})$.

$19886 / 20 / 77$; inside GZ inner fence, $7 \mathrm{~m}$ north of the monument. Planar $\mathrm{Ge}(\mathrm{Li})$.

$19896 / 20 / 77$; inside $\mathrm{GZ}$ inner fence, $10 \mathrm{~m}$ from fence east of the monument. Planar $\mathrm{Ge}(\mathrm{Li})$.

$19906 / 21 / 77$; outside of inner fence at GZ, $12 \mathrm{~m}$ south of east outhouses. Planar $\mathrm{Ge}(\mathrm{Li})$.

$19916 / 21 / 77$; outside of the inner fence at GZ. Located east of entrance road, $13 \mathrm{~m}$ north of the gate. Planar $\mathrm{Ge}(\mathrm{Li})$.

1992 6/21/77; located at Los Alamos National Laboratory GZ study plot, 1 mile north of fence. Taken at west side of the plot near the stake, $20 \mathrm{~m}$ southeast of bunkers, $80 \mathrm{~m}$ southwest of Bagnold sampler. Planar $\mathrm{Ge}(\mathrm{Li})$.

1993 6/22/77; near EPA No. 12117 (Beck Site). Planar Gea Li).

1994 6/27/77; control site, 3 miles south of GZ. V-8 $\mathrm{Ge}(\mathrm{Li})$ set up over stake at southeast corner of plot.

$19956 / 27 / 77$; at northwest corner of plot, 1 mile north of GZ. Same location as No. 1992.
$19966 / 27 / 77$; taken at end of a playa north and west of $\mathrm{GZ}$.

1997 6/27/7\%; I mile north of Beck Site. Same as No. 199.3.

$19986 / 28 / 77 ; 23 \mathrm{~m}$ inside gate at outer fence at GZ and $16 \mathrm{~m}$ of barbed wire fence along roadway.

$19996 / 28 / 77$; corresponds to location at tag word No. 1991.

$20006,28 / 77$; inside inner fence, $10 \mathrm{~m}$ north of gate. Close to No. 1986 location.

$20016 / 28 / 77$; inside inner fence; $7 \mathrm{~m}$ north of the monument.

$20026 / 28 / 77$; inside inner fence, $8 \mathrm{~m}$ west of ferice on east side of the monument.

$20036 / 28 / 77$; inside inner fence, $13 \mathrm{~m}$ from fence north northeast of the monument. Same as No. 1987 location.

$20046 / 28 / 77 ; 1$ mile south of outer gate of GZ, $100 \mathrm{~m}$ west of roadway.

2005 6/29/77; several miles east of Mine Site, about 8-10 miles northeast of GZ. See page 17 of Trinity Field log book for sketch.

2006 6/29/77; near WSMR radar site, close to No. 2005.

2007 6/29/77; east of Nos. 2005 and 2006 in a drainage basin.

$2008 \quad 6 / 29 / 77 ; 1.4$ miles wesi of No. 2007.

$20092 / 29 / 79$; taken in a watering pond 0.7 mile south of Mine Site, which collects sediment from areas to the east.

2010 6/29/77; located at southwest corner of Los Alamos National Laboratory Area 16 study plot.

2011 6/30/77; located at southeast corner of Los Alamos National Laboratory Control Plot 3 miles south of GZ Same location as No. 1994.

2012 6/2 J/77; located I mile east of Junction of Beck Site Road and WSMR, Route 13 and $\sim 50$ miles north of road. 
$20136 / 30 / 77$; located 4.1 miles by road from Beck Site $\mathrm{Road} /$ Route $13 \mathrm{~J}$ unction. Sample site is 1.7 miles north of the point where the road turns north and is $\sim 30$ miles west of road.

$20146 / 30 / 77$; located in bottom of Smith Tank (larger tank to the west); 6.4 miles by road from Beck Site Road/Route 13 Junction and 2.3 miles from No. 2013.

$20156 / 30 / 77$; located at the crest of a ridge 0.3 mile north of Smith Tank.

2016 6/30/ $/ 7$; located 0.4 mile west of ience around Smith Ranch buildings along old road, then 0.2 mile north of road at east edge of an old playa collecting sediment from the east.

$20176 / 30 / 77$; located $\sim 0.4$ mile west of No. 2016 at the west edge of the same playa.

$20: 7 \quad 7 / 4 / 77 ; 6$ miles north of outer fence of $\mathrm{GZ}$ about $30 \mathrm{~m}$ to the east of road.

$20197 / 4 / 77 ; 8-9$ miles north of GZ fence, $\sim 30$ m east of a telephone right of way.

$20207 / 4 / 77$; located 20 miles south of Hwy 380 in a large arroyo. The arroyo is 2.5 miles east of San Antonio.

2021 7/5/77; located above Area 21 study plot at a large black water tower. Same location as No. 2146.

2022 7/5/77: $12 \mathrm{~m}$ south of Meteorological Station at Area 21 study plot on ridge.

2023 7/5/77: on USGS "Broken Back Crater" 15 min quadrangle: P.i.E.: T.4S. Section 10, $600 \mathrm{~m}$ south of $1919 \mathrm{~m}$ elevation marker. In basin.

$20247 / 5 / 77 ; \sim 0.3$ mile east and south of Hinkle Range Headquarters, 0.1 mile east of main highway on dirt access road. Adjacen: to large drainage.

2025 7/6/77; 0.7 mile past turnoff to Area 21 study plot on top of a saddle, 30 miles north of the road.

$20267 / 6,77$; past No. 2025 east to first cattle guard, then south $\sim 0.6$ mile to a point where the drainage basin begins to narrow.

$20277 / 6 / 77 ; \sim 1.5$ to 2 miles east of a gas pump house on the north. Sample site is on a knoll east of a large basin 0.2 mile south of the main road.

$20287 / 6 / 77: \sim 0.5$ mile east $\mathrm{c}$. No. 2027 and 0.3 mile south of the highway in a closed basin.

$20297 / 6 / 77 ;$ same as No. 2028 but $60 \mathrm{~m}$ farther south next to water hole.

$20307 / 6 / 77 ; 150 \mathrm{~m}$ northeast of No. 2028 in same sediment basin.
$20317 / 6 / 77$; same sediment basin as in No. 2028 but up on a slope leading to the basin. Ssuere sheet erosion.

$20327 / 7 / 77 ; \sim 10$ miles south of Hwy $380, \sim 0.3$ mile east of Rio Grande, in dirt tank.

$20337 / 7 / 77 ; 100 \mathrm{~m}$ north of Hwy 380 at bridge over Rio Grande. Detector set up $10 \mathrm{~m}$ into river bed.

$20347 / 7 / 77$; located on a flood plain on east bank of the Rio Grande, 0.25 mile north from bridge.

$20377 / 12 / 77$; below Area 21 at water bank in basin, $\sim 0.5$ mile off main road and $150 \mathrm{~m}$ west of the large dirt tank.

$20387 / 12 / 77$; located at the northeast corner of Area 21 study plot.

$20397 / 12 / 77$; located at the northwest corner of the Area 21 study plot.

$20407 / 12 / 77$; located at the southwest corner of the Area 21 study plot.

$20417 / 12 / 77$; located at the southeast corner of the Area 21 study plot.

$20427 / 12 / 77$; located $100 \mathrm{n} 1$ west of No. 2037 at dirt tank below Area 21.

$20457 / 13 / 77$; located $90 \mathrm{~m}$ north of $20^{\circ}$ west of garage at Copeland Ranch.

$20467 / 13 / 77$; 1 mile south of EPA No. 151 at a windmill. Also, at a section curner 1 mile north and 3 miles east of Copeland Ranch.

2047 7/13/77; replicate of No. 2046, but 100 m northeast.

2048 7/13/77; located at EPA No. 151.

$20497 / 14 / 77$; located on the shoulder of a large enclosed watershed. Located at the depression and tank in Section 24 R.8E., T.25, of "Cat Mesa" USGS quadrangle.

$20507 / 14 / 77 ; 100 \mathrm{~m}$ east of . . 2049 on shoulder. Replicate.

$20517 / 14 / 77$; located in bottom of depression $100 \mathrm{~m}$ east of the water tank. Same depression as Nos. 2049 and 2050.

$20527 / 14 / 77$; replicate of No. $2051,100 \mathrm{~m}$ north and 45 m east of No. 2051.

$20537 / 14 / 77$; located on a ridge top 1 mile north and 0.7 mile east of Copeland Ranch.

$20547 / 14 / 77 ; 100 \mathrm{~m}$ north of No. 2045. Replicate.

$20557 / 14 / 77 ; 4.5$ miles east of Copeland Ranch turnoff, 16 miles south of the road in a wide, low area.

2057 7/18/77; located $\sim 100 \mathrm{~m}$ from Monte Puerto Ranch head yuarters, north $65^{\circ}$ west to front door of house. 
$20587 / 18 / 77$; located $\sim 1.5$ miles south of Monte Puerto Ranch past Bench Mark, then 0.2 mile south of road in open, grassy basin.

2059 7/18/77; located at Mesa Well on Monte Puerto Ranch, northi of the windmill $\sim 200 \mathrm{~m}$.

$20607 / 18 / 77$; located at a dirt tank called South Pothole on the Monte Puerto Ranch, at middle of sediment accumulation.

2061 7/18/77; replicate of No. 2060.

$20627 / 18 / 77 ; 100 \mathrm{~m}$ from fence gate at Pothole.

$20647 / 19 / 77 ; \sim 0.25$ mile south of paved road Nc. 14. This is the Gran Quivira control site and is $\sim 10 \mathrm{~m}$ west of the road just south of the Gran Quivira service road.

$20657 / 19 / 77$; located on Cat Mesa 20 m east of road, 0.1 miles south of Bench Mark 6239.

$20667 / 19 / 77$; located 1.3 miles east of Rugh Well just souch of Maxwell Ranch headquarters, 20 m west of road near junction of several major drainages off Cat Mesa.

$20677 / 19 / 77$; located 2.25 miles south and 1.1 miles west of Mesa Well on the Monte Puerto Ranch.

$20687 / 19 / 77$; located 0.2 mile north of No. 2067 on a ridge.

$20697 / 19 / 77$; located 1.2 miles east of Line Tank on the Monte Puerto Ranch, 0.1 mile east of USGS Bench Mark 6213.

$20717 / 20 / 77$; ridge north of Cuate Tank on Hinkle Ranch.

$20727 / 20 / 77$; located in flat, grassy sediment trap at Cuate Tank on Hinkle Ranch.

2073 7/20/77; replicate of No. 2072, located $100 \mathrm{~m}$ east of No. 2072.

$20747 / 20 / 77$; located 1 mile south of Cuate Tank on south facing slope.

$20757 / 20 / 77$; cabin in the "Y" of the road.

$20767 / 20 / 77$; located near a water tank 3.25 miles east of Maxwell $R$ anch turnoff, $\sim 0.25$ mile south of road.

$20777 / 20 / 77$; iocated at intersection of NM 14 and road to Lovelace/Maxwell Ranches.

$20797 / 21 / 79$; control site, same as No. 2064.

$20807 / 21 / 77$; locatef on NM 14, 2 miles east of pavement past Gran Quivira.

$20817 / 21 / 77$; located on NM 14, 4 miles east of pavement past Gran Quivira.

$20827 / 21 / 77$; located on NM 14, 6 miles east of pavement past Gran Quivira, $100 \mathrm{~m}$ south past place where road turns toward Claunch.
$20837 / 21 / 77$; located on Forest Road 167, 3.5 miles east of NM 14, $20 \mathrm{~m}$ south of road.

$20847 / 21 / 77$; located at the junction of Forest Road 167 and Forest Road 161.

2085 7/21/77; located 3 miles south of Forest Road 167 on Forest Road 161. Site is at the intersection with a road from NM 14 going to the Surrat Ranch.

2086 7/25/77; Gran Quivira control site.

$20877 / 25 / 77$; located near the intersection of SR 14 and the road to the Atkinsen Ranch, T.1.N; R.10.E, Sec. 23 at northeast side of Forest Road 167 and Forest Road 137 je..

2088 7/25/77: located 2 miles east of No. 2087, $10 \mathrm{~m}$ north of the road.

$20907 / 26 / 77$; located 7.25 miles west of SR 42 on Forest Road 167. Located north of the road near an occupied ranch.

$20907 / 26 / 77$; located just east of the intersection of Forest Road 167 and NM 42 at location of EPA No. 19.

$20927 / 26 / 77$; located about 6 miles northwest of Cedarvale on NM 42 at southwest side of roadside rest area.

$20937 / 27 / 77$; located $\sim 1.5$ miles southeast of Cedarvale near aircraft radio beacon at "Corona Airport."

$20947 / 27 / 77$; located on north-south road to Piños Wells in an arroyo upstream to a cattle tank, T.2.N; R.12.E.

2095 7/27/77; same as No. 2094, but moved up to nearest bench to the north above arroyu bottom.

$20967 / 27 / 77$; same as No. 2094, but moved up to nearest bench to the south above the arroyo bottom.

$2097 \quad 7 / 27 / 77$; located in Salt Lake basin (southern extreme) R.13.E; T.2.N.

$20997 / 28 / 77$; located near the junction of NM 42 and the ERDA Solar Irrigation Project turnoff, close to EI'A No. 24.

$21007 / 28 / 77$; located about 22 miles east of Willard on U.S. 60. Located on high ground, that is, slight rise.

L101 7/28/77; located about 15 miles north of Encino on U.S. 285 on east side of road on east ridge of Pedernal Mountain.

2102 to 2113 were locations around Los Alamos used for TA-45, Bayo Canyon, Acid Canyon, and Pueblo Canyon Resurvey. 
2114 8/8/77; Gran Quivira control site.

$21158 / 8 / 77$; located at junction of Forest Roads 99 and 161,10 miles west of NRI 54. Sample site is on the northeast side of the " $T$ " intersection and $30 \mathrm{~m}$ north of Forest Road 161 and $30 \mathrm{~m}$ east of Forest Road 99.

$21168 / 8 / 77$; located $\sim 2.3$ miles east of No. 2115 on Forest Road 161. Site is in a medium-sized arroyu $40 \mathrm{~m}$ north road.

2118 8/9/77; located 5.5 miles west of Corona, 2.5 miles west on Forest Road 141 to "Primitive Road" sign on so!tth side of road, 30 m west of sign.

$21198 / 9 / 77$; located in a saddle $\sim 0.5$ mile southeast of North Peak, 0.7 mile east of For est Road 104 on a "two-rut" road.

$2120 \quad 8 / 9 / 77$; located in a large stream channel just east of Forest Road 140. Site is at the confluence of a side stream with the main channel, 40 m east of Forest Road 140 and just above a newly constructed dirt tank.

2121 8/9/77; located on Gallinas Peak 10 m north of Forest Road 102 at a sinall jeep trail. Site is on the leeward slope (north).

$21228 / 9 / 77$; Replicate of 2121,200 m east.

$21238 / 9 / 77$; located near the intersection of Forest Roads 99 and 102 on Forest Road 102, 50-75 m west of Forest Road $99,10 \mathrm{~m}$ south of road.

$21258 / 10 / 77$; located 3 miles east of NM 54 on the Bond Ranch. Site is $40 \mathrm{~m}$ south of the road in grassy stream bottom.

$21268 / 10 / 77 ;$ located 17.2 miles west of NM 54, past Harvey Ranch.

$21277 / 10 / 77$; located near the windmill at the Erramouspe Ranch.

$21288 / 10 / 77$; located $\sim 0.5$ mile north of the Erramouspe Ranch, is m from dirt tank.

$212910 / 4 / 77$; located at southeast corner of the GZ control plot. Same as Nos. 1985 and 1994.

$213010 / 5 / 77$; located $\sim 2$ miles west of fence at GZ along WSMR No. 20. Site is $150 \mathrm{~m}$ north of road on a playa.
$213110 / 5 / 77 ; 5.5$ to 6 miles north of GZ. Fence at right-hand bend in the road, $50 \mathrm{~m}$ west of apex of turn.

$213210 / 5 / 77$; located near mine site on WSMR. Site is $\sim 60 \mathrm{~m}$ southwest of the white dome.

2133 10/5/77; recount of No. 1998 inside the uuter fence at $\mathrm{GZ}$.

$2134 \mathrm{10} / 5 / 77$; inside inner GZ fence and the right, $\sim 10$ $m$ inside gate.

2135 10/5/77; inside inner GZ fence, north of the monument and $7 \mathrm{~m}$ from fence.

$213610 / 5 / 77$; inside inner fence, $10 \mathrm{~m}$ west of wooden cover.

2138 10/5/77; located on WSMR midway from Route 7 to mine site at intersection of a road leading south.

2139 10/6/77; within outer fence at GZ, from gate, 3rd fence corner in clockwise direction and $20 \mathrm{~m}$ toward monument.

$214010 / 6 / 77$; within outer fence at GZ. Site is at 6 th fence corner clockwise and $15 \mathrm{~m}$ toward monument.

2141 10/6/77; within outer fence at GZ. Site is at 10th corner clockwise and $30 \mathrm{~m}$ toward monument.

2142 10/6/77; southeast corner of Ecology GZ control site.

2143 10/6/77; located at White Sands "Gold" road block along NM $380, \sim 45 \mathrm{~m}$ south of road.

214 20/7/77; Gran Quivira control site.

2146 10/7/77; recount of Nos. 2021 and 1981 above Area 21 at the black water tower.

2147 10/9/77; located 0.5 mile northeast of Bingham in large dirt tank.

2148 10/9/77; located 1.5 miles east of San Antonio along NM 380.

$215310 / 11 / 77$; located 4.6 miles past the first cattle guard after crossing Rio Grande Bridge at Escondida. This is east of the river at Socorro.

2154 10/11/77; located 7.7 miles from No. 2153 along the road. Site is east and a little south of Socorro.

2155 10/11/77; located 9.3 miles from No. 2154 near an old stone house. Site is several miles north of NM 380. 


\section{APPENDIX C}

\section{IN SITU INSTRLMENT CALIBRATION}

\section{CALIBRATION OF INSTRUMENT RESPONSE AND FIELD APPLICATION}

Calibration of in situ gamma-ray spectroscopy instrument response depends on tine distribution of the radionuclides of interest as a function of depth of soil. Naturally occurring radionuclides are usually uniformly distributed, but surface-deposite.' ${ }^{\prime}$ radionuclides such as those from tne Trinity event, which have leached into the soil horizons, exhibit a distribution that is a complicated function of rainfall input, soil properties, vegetation type and density, and the like. Accordingly, soil profile sam: pling at certain of the in situ measurement locations was done, and the results extrapolated to the rest of the locations by a model to be described below.

\section{A. Calibration of Instrument Response}

The response of the closed-end, cylindrical $\mathrm{Ge}(\mathrm{Li})$ detector, placed at a fixed height of one meter above the soil, is an energy-dependent function of the angular response of the detector and the flux of unscattered photons incident at the detector per unit of soil radioactivity.

A general equation expressing this relation is

$N_{\mathrm{f}} / \mathrm{s}=\left(\mathrm{N}_{\mathrm{o}} / \phi\right)\left(\mathrm{N}_{\mathrm{f}} / \mathrm{N}_{\mathrm{o}}\right)(\phi / \mathrm{s})$,

where $N_{f} / s$ is the counting rate in the photopeak per unit of soil radioactivity; No/ $\phi$ is the number of counts in the photopeak of interest per incident photon $/ \mathrm{cm}^{2}$ for a point source at $0^{\circ}$ from the detector's axis; $N_{f} / N_{0}$ is an angular correction factor to account for nonuniform response at angles between $0^{\circ}$ and $90^{\circ}$; and $\phi / \mathrm{s}$ is the theoretical flux of unscattered photous incident at the detector per unit of soil activity. Normally, calibration involves a ca'-ulational procedure inde zendent of the geometries of the distributed sources to be evaluated. Radionuclides that have been redistributed through the vertical profile from an initial surface deposition are usually assumed to be exponentially distributed. As a crosscheck of the laboratory calibration and suitability of the soil sampling for estimation of vertical distribution, an empirical calibration was attempted as well.

The coefficient $N_{f} / \phi=\left(N_{0} / \phi\right)\left(N_{f} / N_{0}\right)$ (that is, the product of the first two terms on the right) represents the total detector registration efficiency for unscattered photons under field conditions. It is a function of the energy and distribution of unscattered photons. The unscattered photon distribution itself is a function of photon energy, source activity distribution vertically and over area, detector height, and the mass attenuation coefficients and densities of soil and air. The source activity distribution and photon energy are the most important parameters. Small variations in the other parameters result in only minor variations in the coefficient $\mathrm{N}_{\mathrm{f}} / \phi$. In A ppendix $\mathrm{D}$, it is shown that an independent determination of this coefficient based on measured instrument response and a source term deveioped from measured vertical profiles of ${ }^{137} \mathrm{Cs}$ activity fitted to an exponential distribution function provides an empirical estimate of detector efficiency, which compares very weil with the laboratory calibration performed at Liwrence Livermore National Laboratory (LLNL).

\section{B. Field Applications}

The gross, short-term stability of the total spectrometer as well as long-term stapility under the stresses of a rather severe environment typical of the New Mexico desert during the summer months were both concerns during field operations.

The gross response of the system was checked at the beginning of each day and at regular intervals during the day by counting a small calibration source placed directly under the detector. As a check of long-term stability, two control plots were selected as convenient background locations that could be repeatedly counted during the course of the field work. One was an intensive study area about 1 mile south of the Trinity event GZ site on the 
White Sands Missile Range; the other was near the Gran Quivira National Park in the vicinity of Chupadera Mesa.

\section{EVALUATIONS OF TRINITY ${ }^{137} \mathrm{Cs}$ DATA}

As a result of the present Trinity resurvey, there are two basic sources of raw data on ${ }^{137} \mathrm{Cs}$ concentrations in soils and biota in the Trinity fallout field: the measurements made on canned samples submitted to LLNL for analysis, and the in situ $\mathrm{Ge}(\mathrm{Li})$ spectral data. For most of the in situ locations, field integration of the cesium peak was made by a reliable approximation technique. These field data and the results of the laboratory measurements of canned samples provided the basis for the preliminary evaluations described in the following discussion.

An essential factor for purposes of estin:ating the total inventory of ${ }^{137} \mathrm{Cs}$ in the soil is the reciprocal of the exponential relaxation depth of contaminant in the soil profile $(\alpha)$. Only nine sample locations on Chupadera Mesa yielded profile concentration data usable for estimating the profile distribution. Of these, three were estimates based on data for the first and third $5-\mathrm{cm}$ profiles only, which would iend to make the estimated profile parameters less reliable. Overall, there is uncertainty in the estimates of $\alpha$ from the soil data because of the way samples were collected and analyzed, as well as the natural variability in the distribution from place to place in the vicinity of the in siru measurement. Estimates of a werc generated from the soil profile data using standard least-squares regression techniques.

In order to extend this profile data set to the remainder of the sample locations $\mathrm{n}$ the mesa, it was determined by multiple regression studies that a useful predictor could be developed from data on the elevation of each sample location and position on the local topological sequence (reduced to simply ridge top, side slope, or depression). The topological sequence information was made quantitative by means of a linear compartment model of ${ }^{137} \mathrm{Cs}$ redistribution during the past 30 years among these topological sequences on the mesa. The iegression relationship derived accounts for $76 \%$ of the variability in the data, which, considering the many sources of variability in ${ }^{137} \mathrm{Cs}$ redistribution through the soil profile, seem remarkably good. Predicted reciprocal relaxation depths ranged from $0.1 \mathrm{~cm}^{-1}$ to $1.2 \mathrm{~cm}^{-1}$, with the higher values (corresponding to shallower distributions) predicted for highest elevations. For simplicity in omputer processing the field $\mathrm{Ge}(\mathrm{Li})$ spectrometer data, thcse predicted values were reduced to one of four values of $\alpha$, uniform $(\alpha=0)$, $0.2,0.4$, or 0.7 . Sample locations off Chupadera Mesa were assigned $\alpha$ values based on judgment and on limited distribution data when available. Ground Zero areas were found to exhibit nearly uniform profiles, while intervenirg regions had protiles typical of worldwide fallout (relaxation depth of $5 \mathrm{~cm}$ ).

The response of a bare $\mathrm{Ge}(\mathrm{Li})$ detector to the inventory of gamma-emitting radionuclides in the soil over which it is placed is dependent on detector-source geometry, photon energy, and the vertical distribution of activity (characterized by the $\alpha$-parameter). Usually the detector is calibrated for photon energy and geometry dependence by the use of sealed sources, while the $a$-dependence is accounted for theoretically. (See Chapter 2 for details on standard calibration techniques.) The in situ calibration efficiency term, $\mathrm{N}_{\mathrm{f}} / \mathrm{s}$, is defined for sealed source calibration by an energy-dependent zero-angle response term, $\mathrm{N}_{\mathrm{f}} / \phi$, an angular correction (geometry) term $\mathrm{N}_{\mathrm{f}} / \mathrm{N}_{\mathrm{o}}$, and an $\alpha$-dependent source term $\phi / s$ :

$N_{\mathrm{f}} / \mathrm{s}=\left(\mathrm{N}_{\mathrm{o}} / \phi\right)\left(\mathrm{N}_{\mathrm{f}} / \mathrm{N}_{\mathrm{o}}\right)(\phi / \mathrm{s})$

where

$\mathrm{N}_{\mathrm{f}} / \mathrm{s}=$ count rate in photopeak/unit of soil activity $\left(\mathrm{nCi} / \mathrm{m}^{2}\right)$,

$\mathrm{N}_{\mathrm{d}} / \dot{\phi}=$ counts per min per incident photon $/ \mathrm{cm}^{2}$ at the detector for a source at $0^{\circ}$ from detector axis,

$\mathrm{N}_{\kappa} / \mathrm{s}=$ angular correction term, and

$\phi / s=$ flux of unscattered photons incident at the detectur per unit of soil activity.

However, the in situ efficiency can also be estimated from field data. In fact, an independent check of the suitability of the relatively weakly determined profile parameter for estimating total profile inventory, $a$, can be made by an independent determination of the efficiency of the detector. $\mathrm{N}_{\mathrm{f}} / \mathrm{s}$, from a set of field data. The flux per unit source, $\phi / s$, is determined mathematically as a function of $\alpha$. The count rate in the photopeak of ${ }^{137} \mathrm{Cs}$ was field-integrated, yielding an estimate of $\mathrm{N}_{\mathrm{f}}$ at each location. "S" can be approximated under the assumption that the ${ }^{137} \mathrm{Cs}$ activity is exponentially distributed in the soil profile by integrating the exponential distribution:

$S=S_{0} \int_{0}^{\alpha} e^{-a x} d x=\frac{S_{0}}{\alpha}$, 
where

$S_{0}=$ approximate activity in the top layer of sul, $\mathrm{nCi} / \mathrm{m}^{2}$, and

$\alpha=$ reciprocal of relaxation depth, $\mathrm{cm}^{-1}$.

$\mathrm{S}_{\mathrm{o}}$ can be approximated from the measured ${ }^{137} \mathrm{Cs}$ concentration at each location where profile data are available with which to estimate $a$. These parameters suffice to determine a lumped parameter, $\mathrm{N}_{\mathrm{f}} / \phi$, which, when multiplied by $\phi / S$, yields an estimate of the calibration factor, $\mathrm{N}_{\mathrm{f}} / \mathrm{S}$. The theoretical relation between $\phi / \mathrm{S}$ and $\alpha$ is shown in Fig. C-1. The product of $\phi / S$ and the estimated $S$ for each measured $\alpha$ divided into $N_{f}$ yields estimates of

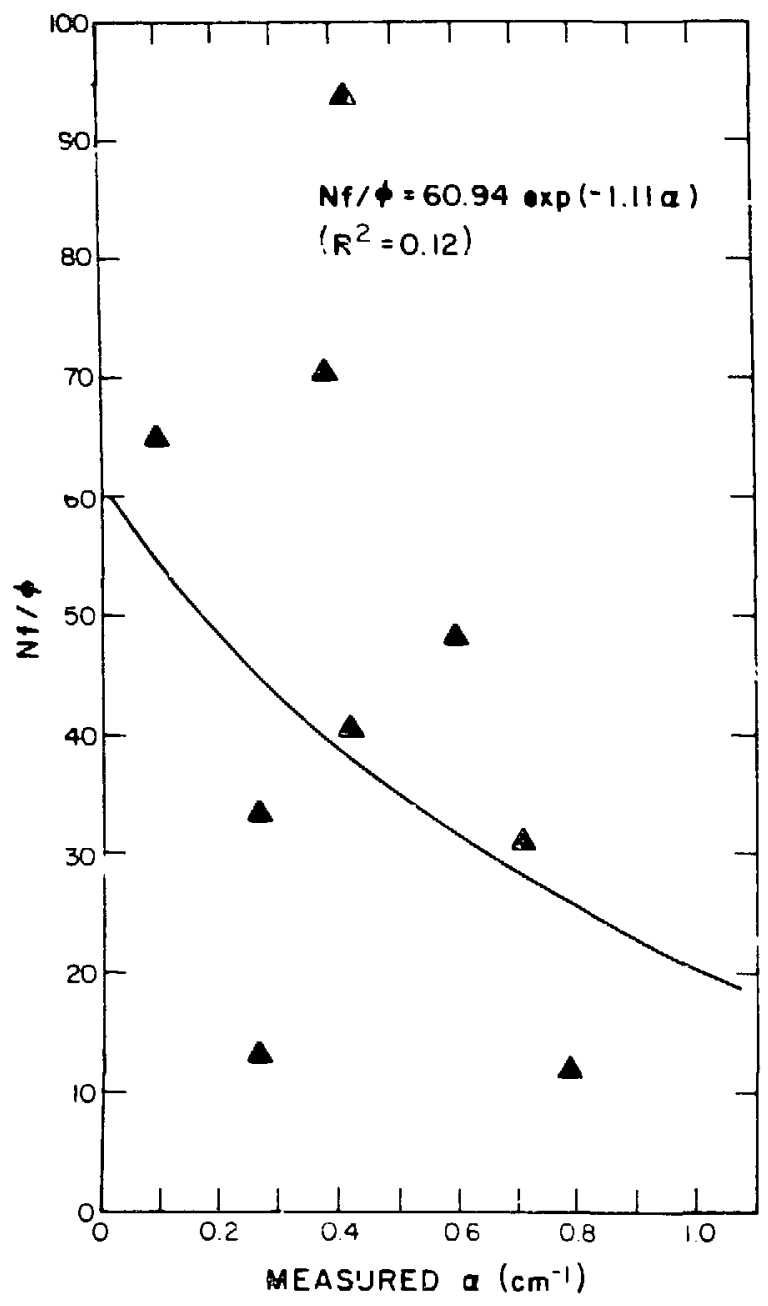

Fig. C-I. $N_{\mathrm{f}} / \phi$ as a function of $\alpha$.
$\mathrm{N}_{\mathrm{f}} / \phi$ as a function of $\alpha$. These values are tabulated in Table C-l. In Fig. C-2, these data are fitted to an exponential curve using standard regression techniques. Ine low coefficient of determination $\left(\mathrm{R}^{2}=0.12\right)$ is indicative of the large variability in the data, and hence the somewhat arbitrary choice of an exponential fit to the data. The predicted calibration term $N_{f} / s=\left(N_{f} / \phi\right)(\phi / s)$ is plotted in Fig. C-2.

\section{STATISTICAL CONSIDERATIONS OF MINI- Miv.1 DETECTABLE ACTIVITY OF ${ }^{137} \mathrm{Cs}$ AND ${ }^{239,240} \mathrm{Pu}$}

In the Trinity resurvey project there were several types of radioactivity measurements made with a variety of equipment and techniques. Results are reported as activity per gram or per square meter. The sensitivity and precision of a given instrumentation and method depends on such parameters as detection efficiency, energy resolution, and background levels. In addition, sample volume, arailable counting time, and degree of statistical precision required are crucial determinants. Following the approach of Walford and Gilboy, ${ }^{\mathrm{Cl}}$ and Kirby, ${ }^{\mathrm{C2}}$ an expression can be derived what will enable an estimation of sensitivity iimits (or minimal detectable activity) in terms of zone of these parameters.

It was assumed that whether ${ }^{137} \mathrm{Cs}$ or ${ }^{239} \mathrm{Pu}$ was being measured, the detection system utilized possessed an energy resolution capability such that radionuclide-specific counts (for example, counts in a photopeak) were identifiable while situated on a background continuum. In this context, precisiun of the count is definable in terms of the coefficient of variatic $\mathrm{i}$, where $\mathrm{c}=$ standard deviation of the net peak counts/net peak counts. If $S$ is the measured peak plus background counts within the channel defining the peak and $B$ and $D$ are the background and peak counts in this region, all measured for a tirne $\mathrm{T}$, then

$\mathrm{S}=\mathrm{D}+\mathrm{B}$

For a highly stable counting system, variation is principally from counting statistics in both the peak channels $(\mathrm{s}=\mathrm{B})^{1 / 2}$ and in the statistical variation in the data on either side, givi:!g rise to an additional variance $\mathrm{V}$. The coefficient of variation can be written in these terms as

$C=\frac{(D+2 B+V)^{1 / 2}}{D}$ 
TABLE C-I

\section{COUNT RATE PER UNIT FLUX \\ AT THE DETECTOR, $N_{N} / \phi$, AS A FUNCTION OF MEASURED $\alpha$}

\begin{tabular}{|c|c|c|c|c|c|}
\hline $\begin{array}{c}\text { Sample } \\
\text { No. } \\
\end{array}$ & $\begin{array}{l}\text { Measured } \\
\alpha\left(\mathrm{cm}^{-1}\right) \\
\end{array}$ & $\begin{array}{l}\text { Inventory } \\
\mathrm{S}\left(\mathrm{nCi} / \mathrm{m}^{2}\right)\end{array}$ & $\begin{array}{c}\text { Measured } \\
\mathbf{N}_{\mathrm{f}} \\
\end{array}$ & $\begin{array}{c}\text { Flux } \\
\phi \\
\end{array}$ & $\mathbf{N}_{\mathrm{f}} / \phi$ \\
\hline 2027 & 0.27 & 187.5 & 111.22 & 3.28 & 33.89 \\
\hline 2045 & 0.27 & 68.8 & 15.76 & 1.2 & 13.09 \\
\hline 2048 & 0.43 & 39.7 & 81.81 & 0.87 & 93.69 \\
\hline 2058 & 0.42 & 193.7 & 170.37 & 4.20 & 40.53 \\
\hline 2071 & 0.39 & 126.8 & 187.0 & 2.66 & 70.27 \\
\hline 2080 & 0.10 & 51.1 & 29.6 & 0.46 & 65.06 \\
\hline 2115 & $0.7 !$ & 66.1 & 56.37 & 1.82 & 31.01 \\
\hline Eis & 0.60 & 54.6 & 69.02 & $! .42$ & 48.63 \\
\hline 2120 & 0.79 & 252.7 & 88.05 & 7.33 & 12.02 \\
\hline
\end{tabular}

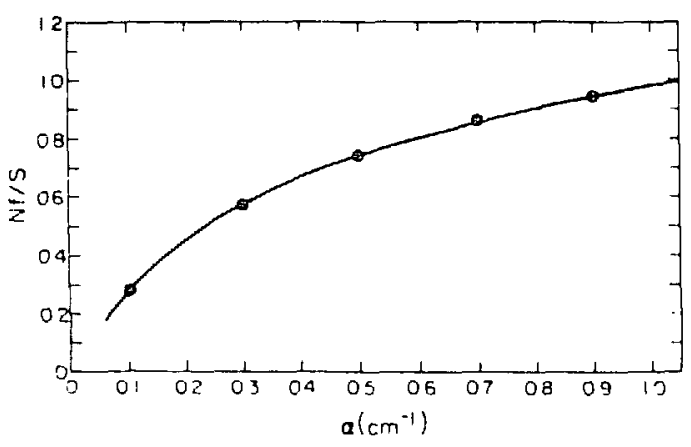

Fig. $C$-2. $N_{\mathrm{f}} / s=N_{\mathrm{f}} / \phi \cdot \phi_{\mathrm{f}}^{\prime}$ s as a function of $\alpha$

Solving for $\Gamma$ yieids

$$
D=\frac{\left\{l+\left\{l+4 C^{2}(2 B+V)\right\}^{1 / 2}\right\}}{2 C^{2}} .
$$

The total count in a peak is a product of the detector peak efficiency, $N_{f} / S$, which is the count rate in the peak per unit activity in the ground $S$, the time of the count $T$, and the activity in the ground $S_{A}$

$D=\left(N_{r} / S\right)(T)\left(S_{A}\right)$.
The minimal detectable level of activity (minimum $S_{A}$ ) is, thus, from Eqs. (C-6) and (C-7)

$\left.\left.S_{\min }=\frac{1}{2 C^{2}\left(N_{f} / s\right) T} l\right) 1+\left|1+4 C^{2}(2 B+V)\right|^{1 / 2}\right\}$

Since the variance in the net peak counts, VAR(D), is the square of the numerator of Eq. (C-5), the quantity (2B + $\mathrm{V})$ in Eq. (C-8) can be replaced by the equivalent VAR(D) - D. This permutation allows calculation of the minimum detectable activity without introducing the specific background count. The in situ and laboratory $\mathrm{Ge}(\mathrm{Li})$ data are reported oniy in terms of peak count rate and standard deviation or fructional standard deviation.

If the criterion of acceptability is that the coefficient of variation be no larger than 0.3 for a typical count time of $2000 \mathrm{~s}$ (33.3 $\mathrm{min})$, then $\mathrm{S}_{\min }$ becomes

$S_{m i n}=\frac{0.167}{N_{f} / s}\left\{1+\left\{1+0.36\left(\left.V A R(D)\right|^{1 / 2}\right\}\right.\right.$.

For the known peak count, $R$, and the fractional stand $d_{u}$ rd deviation of the peak count rate, $\sigma_{\mathrm{cpm}}, \mathrm{S}_{\mathrm{mln}}$ becomes $S_{r ? ! n}=\frac{0.167}{N_{\mathrm{f}} / \mathrm{s}}\left\{1+\left|1+400\left(\sigma_{\mathrm{cpm}} R^{2}-0 / 03 R\right)\right|^{1 / 2}\right\}$. 


\section{REFERENCES}

C1. H. G. V. Walford and W. B. Gilboy, "Fundamentals of Sensitivity Units in Low Level Counting," in The Proc. Natural Radiation Environment II, August 7-11, 1972, Houston, Texas (1973).
C2. J. A. Kirby, L. R. Anspaugh, P. L. Phelps, G. A. Armantrout, and D. Sawyer, "A Detector System for In Situ Spectrometric Analy sis of ${ }^{241} \mathrm{Am}$ and $\mathrm{Pu}$ in Soil," IEEE Transactions on Nuclear Science (February 1976). 


\section{APPENDIX D}

\section{INTERPRETATION OF DATA}

This appendix provides the information and assumptions used to calculate the doses from the current conditions at Trinity Site and the fallout zone to the northeast including Chupadera Mesa. The land uses in the area include the restricted area of White Sands Missile Range, grazing of cattle, and a few crops grown in the far fallout areas. Chupadera Mesa is all grazing with ranches ranging in size from 100 square miles to some exceeding 200 square miles. Home gardening is practiced with irrigation wàier being supplied from wells. Well water samples did not contain any significant amourts of the fallout radionuclides now remaining in the area.

\section{SOILS DATA BY AREA}

\section{A. Background Levels of Radionuclides and Radiation}

Reference values for background concentrations of radioactivity in soils and sediments attributable to natural constituents or general worldwide fallout were assembled from several studies to provide a basis for comparison (Refs. D1, D2, D3, and D4). This information is summarized in Table D-1. Most of the data were from a compilation on soils and sediments collected in northern New Mexico over the period 1974-1977 as part of the Los Alamos National Laboratory routine environmental surveillance program. Some of the data were taken from other studies representing generally smaller numbers of samples.

The data in Table D-I can be used only as a general comparison for the data taken for Trinity fallout zone. The distribution of worldwide fallout radionuclides varies with latitude and longitude in the U.S. However, the data for northern New Mexico are the only compilation available for this area of the U.S.

\section{B. Survey Sample Results}

I. Trinity Site GZ Area. Measurements of the radiation present at GZ of Trinity Site were started very early.
On July 16,1945, measurements at 30000 feet to the north of $G Z$ recorded $10 \mathrm{R} / \mathrm{h}$, while 30000 feet to the west only $0.2 \mathrm{R} / \mathrm{h}$ was recorded (Ref. D5). At 12000 feet south of GZ, nothing was recorded. At 4500 feet south, $0.011 \mathrm{R} / \mathrm{h}$ was recorded. At 6:30 p.m. on July 16, 1945, a measurement 30 feet west of $G Z$ recorded 6000 R/h (Ref. D5). Measurements made August 12 and 14, 1945 , recorded $7 \mathrm{R} / \mathrm{h}$ at $\mathrm{GZ}$ with a circular area around GZ reading $15 \mathrm{R} / \mathrm{h}$ (Ref. D6). In Octnber, 1945, a number of excavations were made to study the blast effects of the test (Ref. D7).

Ground disturbances at the GZ area occurred a number of iimes. In 1947, the Trinitite containing the most radioactivity was placed in 12 drums and buried inside the GZ area (Ref. D8). In 1952, the removal of the top inch of earth including the remaining lower activity Trinitite was arranged (Ref. D9). In 1965 a monument was erected at the center of the GZ tower. In 1967 a detailed radiulogical survey was conducted to document the radiation doses present. The study detected a high of $3 \mathrm{mR} / \mathrm{h}$ and low of $0.03 \mathrm{mR} / \mathrm{h}$ within the fenced areas (Ref. D10). At the same time, the 12 drums of Trinitite were dug up with a backhoe and shipped to Los Alarios National Laboratory where disposai was accomplished in the low-level waste burial facility (Ref. D8). The 1967 study concluded there was no risk to persons visiting the site. .

Visits by the public to the site currently are limited to an Army-sponsored 2-h stay time. The keys to the area are only available from the White Sands Missile Range security office and only after approval by the safety officer.

In 1977 the radiation survey for the DOE Kemedial Action Programs made a few surface measurements at GZ. However, no data were taken on the depth of contamination during previous surveys. In 1983 both auger samples and split-spoon samples were obtained in the fenced areas of GZ. Figure D1 indicates the locations of the soil samples at depth as well as locations of air samples and external radiation measurements. External 
TABLE D-I

\section{NORTHERN NEW MEXICO BACKGROUND REFERENCE VALUES FOR NATURAL OR FALLOUT LEVELS OF RADIOACTIVITY}

\begin{tabular}{|c|c|c|c|c|c|c|}
\hline Isotope & $\begin{array}{c}\text { Mean } \\
\text { Concentration } \\
(\bar{x} \pm s)\end{array}$ & $\begin{array}{c}\text { Range of } \\
\text { Concentrations } \\
\end{array}$ & Units & $\begin{array}{l}\text { No. of } \\
\text { Samples }\end{array}$ & Comment & Reference \\
\hline${ }^{239} \mathrm{Pu}$ & $0.008 \pm 0.010$ & $<0.002-0.045$ & $\mathrm{pCi} / \mathrm{g}$ & 149 & $\begin{array}{l}\text { Soils and sediments } \\
0-5 \mathrm{~cm}\end{array}$ & DI \\
\hline${ }^{238} \mathrm{Pu}$ & $<0.000 \pm 0.0064$ & $<0.003-0.010$ & $\mathrm{pCi} / \mathrm{g}$ & 151 & $\begin{array}{l}\text { Soils and sedin ants } \\
0-5 \mathrm{~cm}\end{array}$ & D1 \\
\hline${ }^{241} \mathrm{Am}$ & $0.004 \pm 0.004$ & $<0.001-0.009$ & $\mathrm{pCi} / \mathrm{g}$ & 7 & Sediments $0-5 \mathrm{~cm}$ & $\mathrm{E}:$ \\
\hline${ }^{90} \mathrm{Sr}$ & $0.25 \pm 0.27$ & $<0.05-1.0$ & $\mathrm{pCi} / \mathrm{g}$ & 68 & $\begin{array}{l}\text { Soils and sediments } \\
0-5 \mathrm{~cm}\end{array}$ & DI \\
\hline${ }^{137} \mathrm{Cs}$ & $0.32 \pm 0.30$ & $<0.10-1.06$ & $\mathrm{pCi} / \mathrm{g}$ & 76 & $\begin{array}{l}\text { Soils and sediments } \\
0-5 \mathrm{~cm}\end{array}$ & {$[\mathrm{D}]$} \\
\hline Total U & $18 \pm 1.3$ & $<0.1-5.1$ & $\mu \mathrm{g} / \mathrm{g}$ & 118 & $\begin{array}{l}\text { Soils and sediments } \\
0-5 \mathrm{~cm}\end{array}$ & D1 \\
\hline${ }^{232} \mathrm{Th}$ & $14.3 \pm 3.6$ & $9.2-20.1$ & $\mu \mathrm{G} / \mathrm{G}$ & 8 & Soils $v-30 \mathrm{~cm}$ & D3 \\
\hline${ }^{226} \mathrm{Ra}$ & $2.4 \pm 0.8$ & $1.6-3.9$ & $\mathrm{pCi} / \mathrm{g}$ & 7 & Soil $0-5 \mathrm{~cm}$ & D4 \\
\hline
\end{tabular}

radiation measurements were made with four thermoluminescent dosimeters (TLDs) at each location.

Tables D-II and D-III provide the data from soil samples for ${ }^{239-240} \mathrm{Pu}$ and ${ }^{152} \mathrm{Eu}$. Samples from the GZ inner fence area exhibit ${ }^{239-240} \mathrm{Pu}$ levels 1.5 to 2.5 times proposed guidance levels of $100 \mathrm{pCi} / \mathrm{g}$ developed by the DOE Remedial Action Programs (Ref. D11). The quantities in the GZ sainples alsc exceed the U.S. Environmental Protection Agency (EPA) guidance on transuranics of $0.2 \mu \mathrm{Ci} / \mathrm{m}^{2}$ for the top $1 \mathrm{~cm}$ of soil (Ref. D 12).

Examination of the ${ }^{239-240} \mathrm{Pu}$ surface sample data for between the fences indicates none of the surface samples exceeds the Remedial Actions Program criteria. Table DIV includes the means for surface samples at similar distances from GZ. None of the means exceeds either
DOE or EPA proposed criteria for surface contamination. For soil samples between $1-6 \mathrm{~cm}$ taken between the fences, all results were below DOE and EPA proposed criteria. Eslow $40 \mathrm{~cm}$ (16 inches), all soil sample results for ${ }^{239-240} \mathrm{Pu}$ were the same as fallout levels in northern New Mexico.

Europium-152 is the predominant gamma-ray emitter in the soils of the GZ area. In undisturbed areas between the fences around $\mathrm{GZ}$, the ${ }^{152} \mathrm{Eu}$ appeared in soil samples at deeper levels than plutonium. This would appear to suggest some mobility greater than plutonilim. Also, measurements by in situ gamma-ray spectroscopy in dicate ${ }^{152} \mathrm{Eu}$ is the major contributor to external radiation doses at $\mathrm{GZ}$. There are no specified criteria for the amount of ${ }^{193} \mathrm{Eu}$ in soils. However, the DOE limits the 


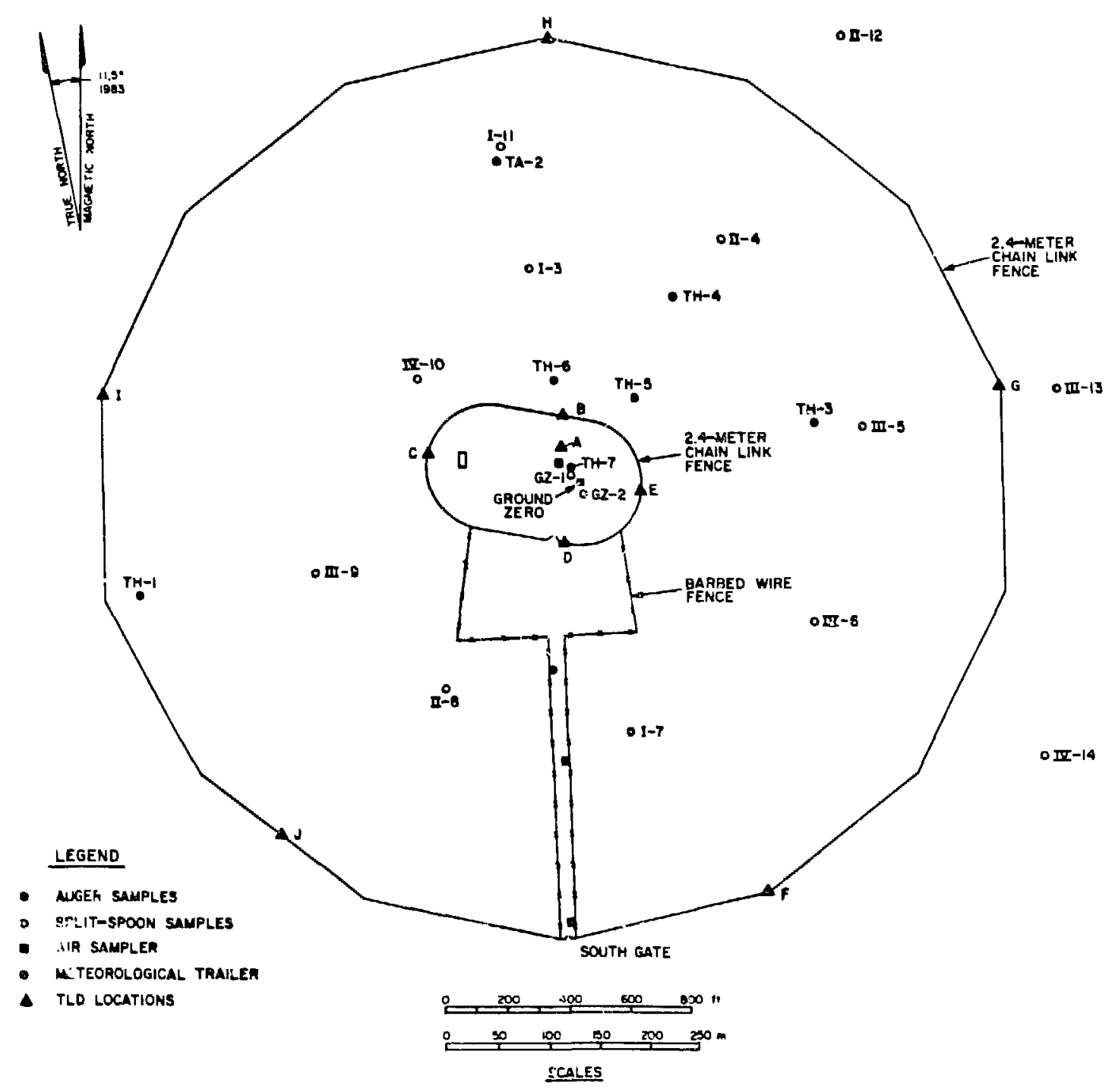

Fig. D-1. Location of June 1983 sampling.

maximum acc: table whole-body exposure to 500 $\mathrm{mrem} / \mathrm{yr}$. The annual visit allowed by the Army would result in a maximum dose of $1 \mathrm{mrem} / \mathrm{yr}$ added to about $150 \mathrm{mrem} / \mathrm{yr}$ from natural radiation for the area. The average dose per 2 -h visit is likely to be about 0.5 mrem.

\section{Radioactivity in Soils of Trinity rallont Areas.} Based on the soil data taken by this survey and the 1973 and 1974 survey by the U.S. EPA, the ${ }^{239-240} \mathrm{Pu}$ arithmetic mean content of surface soils and deeper soil sampies is less than criteria for removal by both the DOE and
EPA. That is, the levels are considered safe for cont:nuous residence by the public in the area. The plutonium content and content of other radionuclides from the Trinity test fallout are summarized in Tables XIV through XIX in Chapter 4 . The tables are summaries of the data from Appendix A.

\section{DCSE CALCULATIONS}

The EPA guidarce for transuranics in the general environment is based on a set of assumptions on how 


\section{TABLE D-II}

1983 PLUTONIUM DATA FOR SPLIT SPOON CORE SAMPLES FROM GROUND ZERO AREA

${ }^{239-240} \mathrm{Pu}(\mathrm{pCi} / \mathrm{g})$

\begin{tabular}{|c|c|c|c|c|c|c|}
\hline \multicolumn{7}{|c|}{ Sample Number and Distance from GZ } \\
\hline Depth & $G Z 1(12 \mathrm{~m})$ & $\mathrm{GZ}-2(12 \mathrm{~m})$ & Depth & $\mathrm{I}-3(210 \mathrm{~m})$ & II-4 (275 m) & III-5 (280 m \\
\hline $0.1 \mathrm{~cm}$ & - & $22.8000 \pm 0.2000$ & $0.1 \mathrm{~cm}$ & $20.6000 \pm 0.2000$ & $0.3100 \pm 0.0200$ & $0.9900 \pm 0.0300$ \\
\hline $1.6 \mathrm{~cm}$ & $\cdots$ & $156.0000 \pm 15.0000$ & $1.6 \mathrm{~cm}$ & $\cdots$ & $0.1810 \pm 0.0150$ & $0.0440 \pm 0.0140$ \\
\hline $0.6 \mathrm{in}$ & $\ldots$ & $23.7000 \pm 0.4000$ & $16.22 \mathrm{in}$. & $0.0056 \pm 0.0010$ & $0.0043 \pm 0.0010$ & $0.0022 \pm 0.0010$ \\
\hline $6.12 \mathrm{in}$. & $256.0000 \pm 3.0000$ & $\ldots$ & 22.28 in. & $0.0029 \pm 0.0010$ & $0.0110 \pm 0.0030$ & $0.0041 \pm 0.0010$ \\
\hline 121817 & $0.4000 \pm 0.0200$ & $\ldots$ & & & & \\
\hline $18-24$ in. & $1.3300 \pm 0.0400$ & & & \\
\hline $24-30 \mathrm{mn}$. & $\ldots$ & $9.9000 \div 0.3000$ & & & & \\
\hline $30.36 \mathrm{in}$. & -. & $0.1030 \pm 0.0080$ & & & & \\
\hline 36.42 in. &.. & $4.9300 \pm 0.1300$ & & & & \\
\hline $42-48$ in. & $\cdots$ & $0.1350 \pm 0.0080$ & & & & \\
\hline Depth & IV.6 $(265 \mathrm{~m})$ & $1.7(250 \mathrm{~m})$ & $11.8(245 \mathrm{~m})$ & Depth & IV. $10(185 \mathrm{~m})$ & $\mathrm{I}-11(330 \mathrm{~m})$ \\
\hline $0.1 \mathrm{~cm}$ & $5.0900 \pm 0.8000$ & \multirow{3}{*}{$\begin{array}{l}0.0440 \pm 0.0070 \\
0.0590 \pm 0.0080\end{array}$} & $27.5000 \pm 0.3000$ & $0.1 \mathrm{~cm}$ & $0.5600 \pm 0.036 \mathrm{n}$ & $8.5000 \pm 0.1500$ \\
\hline \multirow[t]{2}{*}{$1.6 \mathrm{~cm}$} & $\ldots$ & & $0.7300 \pm 0.0400$ & $1.5 \mathrm{~cm}$ & $0.1570 \pm 0.015 n$ & -. \\
\hline & & & & $4-10$ in. & $0.0230 \pm 0.0050$ & \\
\hline $16.22 \mathrm{in}$. & $0.0021 \pm 0.0010$ & & $0.0100 \pm 0.0020$ & $16-22$ in. & $0.0021 \pm 0.001 \mathrm{C}$ & $0.0068 \pm 0.0010$ \\
\hline $22.28 \mathrm{ln}$ & $0.0070 \pm 0.0020$ & $0.0160 \pm 0.0030$ & $0.0180 \div 0.0030$ & 22.28 in. & $0.0005 \pm 0.0000$ & $0.0130 \pm 0.0020$ \\
\hline Depth & II- $12(510 \mathrm{~m})$ & {$[12-13(475 \mathrm{~m})$} & IV $-14(520 \mathrm{~m})$ & Depth & Control $(5200 \mathrm{~m})$ & \\
\hline $0.1 \mathrm{~cm}$ & $0.0430 \pm 0.0080$ & $0.0940 \pm 0.0130$ & $0.0410 \neq 0.0090$ & $0-1 \cap$ & $0.0019: 0.0010$ & \\
\hline $1.6 \mathrm{~cm}$ & $0.0410 \pm 0.0100$ & $0.1500 \pm 0.0200$ & $0.0190 \pm 0.0060$ & $1-2 \mathrm{ft}$ & $0.0006=0.0000$ & \\
\hline 16.22 in. & $0.0110 \pm 0.0020$ & $0.0025 \pm 0.0010$ & $0.0047 \pm 0.0010$ & $2-3 \mathrm{ft}$ & $0.0024 \pm 0.0010$ & \\
\hline $22.28 \mathrm{in}$ & $0.0038 \pm 0.0010$ & $0.0091 \pm 0.0010$ & $0.0040 \pm 0.0010$ & $3-4$ ก & $0.0011 \pm 0.0000$ & \\
\hline
\end{tabular}


TABLE D-III

$1983{ }^{152}$ Eu DATA FROM SPLIT SPOON CORE SAMPLES IN GROUND ZERO AREA

${ }^{192} \mathrm{Eu}(\mathrm{pCi} / \mathrm{g})$

\begin{tabular}{|c|c|c|c|c|c|c|}
\hline \multicolumn{7}{|c|}{ Sample Number and Distance from GZ } \\
\hline Depth & GZ-1 $(10 \mathrm{~m})$ & GZ-2 (12 m) & Depth & $\mathrm{J} \cdot 3(210 \mathrm{~m})$ & Il-4 (275) & III. $(280 \mathrm{~m})$ \\
\hline $0-: \mathrm{cm}$ & ..- & $284.3388 \pm 29.0322$ & $0-1 \mathrm{~cm}$ & $33.6445 \pm 3.5359$ & $13.3744 \pm 1.7 ! 59$ & $9.9419 \pm 1.3869$ \\
\hline $1-6 \mathrm{~cm}$ & $\cdots$ & $245.4959 \pm 24.9538$ & $16 \mathrm{~cm}$ & $30.8438 \pm 3.4902$ & $10.5350 \pm 1.2412$ & $10.0096 \pm 1.4444$ \\
\hline 0.6 in. & $500.7191 \pm 90.6747$ & $264.5681 \pm 26.8594$ & 4-10 in. & $14.7625 \pm 1.6236$ & $5.4157 \pm 0.9014$ & $5.3234 \pm 0.8980$ \\
\hline 6.12 in. & $1069.0675 \pm 107.7231$ & $957.6400 \pm 96.2607$ & $10-16 \mathrm{in}$ & $5.7801 \pm 0.6222$ & $0.8868 \pm 0.7104$ & $2.2046 \pm 0.2800$ \\
\hline $12.18 \mathrm{ln}$. & $282.0225 \pm 28.3633$ & $169.0552 \pm 17.4506$ & $16-22 \mathrm{in.}$ & $0.9959 \pm 0.15 .5$ & $0.5379 \pm 0.2188$ & $0.7792 \pm 0.2400$ \\
\hline $18.24 \mathrm{ln}$. & $40.1567 \pm 4.0812$ & $222.9221 \pm 22.4308$ & 22.28 in. & $0.8026 \pm 0.1551$ & $0.2654 \pm 0.11115$ & $0.3642 \pm 0.1086$ \\
\hline 24.30 เn. & $22.5086 \pm 2.2929$ & $129.8201 \pm 13.0731$ & $28-34$ in. & $1.4461 \pm 0.2819$ & $\ldots$ & $\ldots$ \\
\hline $30 \cdot 36$ in. & $0.5566 \pm 0.1335$ & $24.1423 \pm 2.4523$ & 34.40 in. & $0.0415 \pm 0.1552$ & $\ldots$ & ... \\
\hline $36-42$ in. & $1.0331 \pm 0.1636$ & $10.4316 \pm 1.0858$ & $40-46$ in. & $0.1959 \pm 0.1169$ & -.. & $\ldots$ \\
\hline $12.48 \mathrm{in}$ & $0.4203 \pm 0.1278$ & $3.9016 \pm 0.4443$ & $\therefore=-2$ in. & $0.3665=0.1436$ & ... & $\ldots$ \\
\hline
\end{tabular}

\begin{tabular}{|c|c|c|c|c|c|c|c|}
\hline Depth & IV. $6(265 \mathrm{~m})$ & $1.7(230 \mathrm{~m})$ & IV.10 (185 m) & Depth & $\mathrm{I}-11(330 \mathrm{~m})$ & $11.12(510 \mathrm{~m})$ & III $13(479 \mathrm{~m})$ \\
\hline $0.1 \mathrm{~cm}$ & $13.8847 \pm 1.6654$ & $3.4109 \pm 0.3888$ & $58.6909 \pm 6.1822$ & $0-1 \mathrm{~cm}$ & $5.1252 \pm 1.0778$ & $1.3496 \pm 0.6956$ & $0.0760 \pm 0.2515$ \\
\hline $16 \mathrm{~cm}$ & $25.9154 \geq 2.0174$ & $4.5362+1.1405$ & $46.1493 \pm 4.8400$ & $1-6 \mathrm{~cm}$ & $3.5483 \pm 0.9248$ & $1.1844 \pm 0.5268$ & $2.5695 \pm 1.0400$ \\
\hline $4-10 \mathrm{in}$ & $2.0848 \pm 1.5203$ & $2.8248 \pm 0.8713$ & $23.0370 \pm 2.5576$ & 4.10 in. & $0.8999 \pm 0.7806$ & $2.1175 \pm 0.5756$ & $0.6602 \pm 0.4074$ \\
\hline 10.16 in. & $4.1317 \pm 0.9492$ & $0.4960 \pm 0.1940$ & $5.7562+0.6522$ & $10-16 \mathrm{in.}$ & $2.1553 \pm 0.6975$ & $0.6941 \pm 0.4311$ & $0.4506 \pm 0.5043$ \\
\hline $16.22 \mathrm{ln}$. & $0.6858 \pm 0.1823$ & $0.2761 \pm 0.1871$ & $1.5456 \pm 0.2405$ & 16.22 in. & $0.3492 \pm 0.1666$ & $0.4024 \pm 0.1540$ & $0.6390 \pm 0.2391$ \\
\hline $22-28 \mathrm{in}$ & $0.4285 \pm 0.1389$ & $0.4526 \pm 0.1697$ & $0.5428 \pm 0.1321$ & 22.28 in. & $0.2080 \pm 0.1061$ & $0.2385 \pm 0.2039$ & $0.2231 \pm 0.1409$ \\
\hline $28.34 \mathrm{in}$ & $\cdots$ & $\cdots$ & $0.4930 \pm 0.1476$ & $\ldots$ & $\ldots$ & .. & $\ldots$ \\
\hline $34-40$ in. & $\cdots$ & $\cdots$ & $0.2072 \pm 0.4930$ & $\ldots$ & $\ldots$ & $\ldots$ & $\ldots$ \\
\hline
\end{tabular}

\begin{tabular}{|c|c|c|c|c|c|}
\hline Depth & IV. $14(520 \mathrm{~m})$ & Depth & $11-8(245 \mathrm{~m})$ & Depth & II-8c $(249 \mathrm{~m})$ \\
\hline $0.1 \mathrm{~cm}$ & $0.6312 \pm 0.5778$ & $0-6 \mathrm{in}$. & $18.2777 \pm 2.2156$ & $0-1 \mathrm{~cm}$ & $25.0172 \pm 3.0114$ \\
\hline $1.6 \mathrm{~cm}$ & $0.1291 \pm 0.4440$ & $6.12 \mathrm{in.}$ & $5.2162 \div 0.9229$ & $1-6 \mathrm{~cm}$ & $21.0319 \pm 2.7315$ \\
\hline $4.10 \mathrm{in}$ & $0.5836 \pm 0.2980$ & $12.18 \mathrm{in.}$ & $4.1792 \pm 0.1840$ & $8.11 \mathrm{~cm}$ & $16.4178 \pm 21762$ \\
\hline $10-15 \cdot \cdots$ & $0.1585 \pm 0.5181$ & 18.25 in. & $0.2456 \pm 0.1056$ & $8.13 \mathrm{in.}$ & $6.7864 \pm 1.0562$ \\
\hline $16-22$ & $\ldots$ & $24.30 \mathrm{in.}$ & $0.3192 \pm 0.1996$ & 13-19 in. & $2.2228 \pm 0.2649$ \\
\hline $22-28 \mathrm{in.}$ & $0.4468 \pm 0.1902$ & $30-36$ in. & $0.4045 \pm 0.1628$ & $19-25$ in. & $0.6343 \pm 0.1665$ \\
\hline$\cdots$ & $\cdots$ & $36-42 \mathrm{in.}$ & $0.3108 \pm 0.1398$ & $25-27-1 / 2$ in. & $0.4335 \pm 0.1455$ \\
\hline
\end{tabular}


TABLE D-IV

JUNE 1983 PLUTONIUM DATA FROM TRINITY GZ AREA

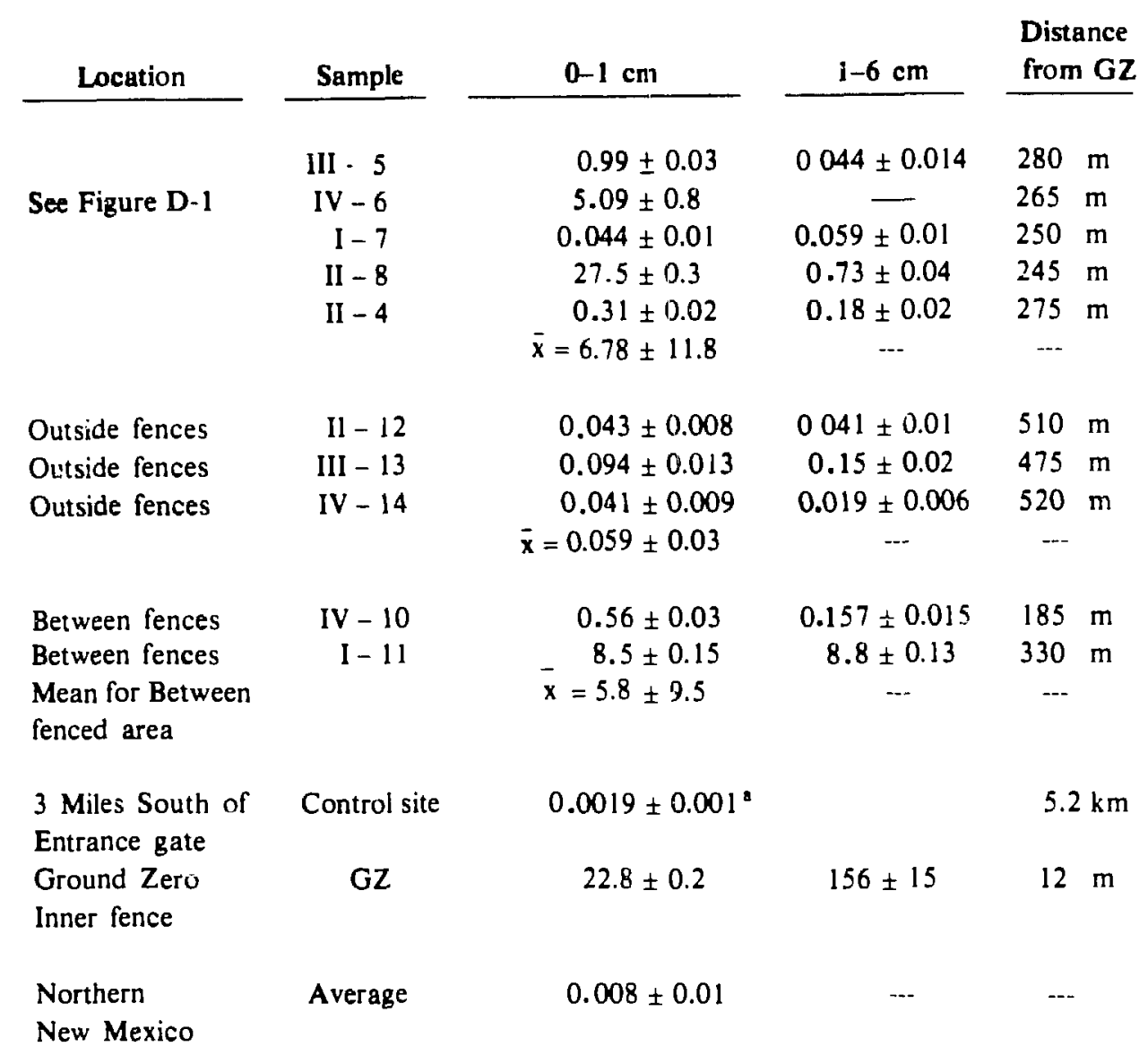

'Data for 0-1 foot.

radionuclides reach man. The guidance only considers transuranic elements such as plu nium. In the Trinity fallout zone, there are also residual fission products. The residual fission products are dominated by ${ }^{137} \mathrm{Cs}$ and ${ }^{90} \mathrm{Sr}$. Thus, investigations regarding the safety of living in the fallout zone need to consider the total doses from all radionuclides present.

The doses are from three major paths to man. The external radiation doses as measured are reported in Chapter 4. The doses from inhalation and ingestion of radionuclides in air and food require calculational estimates. The following sections discuss the information used for these calculations, as well as jresent, intermediate, and final results.

\section{A. Inhalation of Radionuclides}

The residual contamination in the soils of the fallout zone provides a source of particulate matter that may be resuspended by wind movement or other mechanical 
TABLE D-V

PARAMETERS F'JR ESTIMATION OF RESUSPENSION OF RADICNUCLIDES USING MASS LOADING

$\left(24 \mu \mathrm{g} / \mathrm{m}^{3}\right)^{\mathrm{a}}$

\begin{tabular}{|c|c|c|c|c|c|c|c|c|}
\hline \multirow[b]{2}{*}{ Arca } & \multicolumn{3}{|c|}{$\begin{array}{c}\text { Effective Soil } \\
\text { Concentration (pCi/g) }\end{array}$} & \multirow[b]{2}{*}{$\Sigma \mathbf{g}_{1} \mathbf{f}_{1}$} & \multicolumn{3}{|c|}{$\begin{array}{l}\text { Estimated Annual } \\
\text { Average Air } \\
\text { Concentration }\left(\mu \mathrm{Ci} / \mathrm{m}^{3}\right)\end{array}$} & \multirow{2}{*}{$\begin{array}{l}\text { Measured } \\
{ }_{239,240} \mathrm{Pu} \\
\left(\mu \mathrm{Ci} / \mathrm{m}^{3}\right)\end{array}$} \\
\hline & ${ }^{239.240} \mathrm{Pu}^{\mathrm{b}}$ & ${ }^{90} \mathrm{Sr}$ & ${ }^{137} \mathrm{Cs}$ & & ${ }^{239,240} \mathrm{Pu}$ & ${ }^{90} \mathrm{Sr}$ & ${ }^{137} \mathrm{Cs}$ & \\
\hline \multicolumn{9}{|l|}{ Trinity Site } \\
\hline Inner Fence & 22.8 & $\ldots$ & 16.5 & $0.07 !$ & $3.8 \times 10^{-11}$ & $\ldots$ & $2.8 \times 10^{-11}$ & $6.3 \times 10^{-11}$ \\
\hline Outer Fence & 5.8 & $\ldots$ & 0.54 & 0.071 & $9.8 \times 10^{-12}$ & $\ldots$. & $9.2 \times 10^{-13}$ & $0.1 \times 10^{-11}$ \\
\hline White Sands & $\mathrm{i} 3.2^{\mathrm{b}}$ & 1.8 & 4.5 & 0.071 & $2.2 \times 10^{-11}$ & $3 \times 10^{-12}$ & $1.8 \times 10^{-12}$ & -.- \\
\hline Bingham & $0.36^{\mathrm{c}}$ & -- & $3.7^{\mathrm{c}}$ & 0.78 & $6.7 \times 10^{-12}$ & -.- & $6.9 \times 10^{-11}$ & $\ldots$ \\
\hline Chupadera Mesa & $3.2^{\mathrm{b}}$ & 2.3 & 2.8 & 1.6 & $1.2 \times 10^{-10}$ & $8.8 \times 10^{-11}$ & $1.1 \times 10^{-10}$ & $4.1 \times 10^{-11 d}$ \\
\hline Far Fallout Zone & $0.57^{\mathrm{b}}$ & 1.47 & 2.0 & 1.6 & $2.2 \times 10^{-11}$ & $5.6 \times 10^{-11}$ & $7.7 \times 10^{-11}$ & -.. \\
\hline San Antonio, NM & $0.019^{b}$ &.- & $4.8^{\mathrm{c}}$ & 1.6 & $7.3 \times 10^{-13}$ & --- & $1.8 \times 10^{-10}$ & $4.3 \times 10^{-11 d}$ \\
\hline \multicolumn{9}{|c|}{$\begin{array}{l}{ }^{\text {a }} \text { Reference D } 13 . \\
\text { bor samples other than } 1 \mathrm{~cm} \text { deep, a Correction Factor Applied for profit distribution: } 1.32 \text { for White } \\
\text { Sands, } 0.34 \text { for Bingham, } 1.9 \text { for Chupadera Mesa, Far Fallout Zone and San Antonio. See Reference } \\
\text { D14. }\end{array}$} \\
\hline
\end{tabular}

action. Such airborne particulate matter could be inhaled by persons occupying the areas. Few direct measurements of total airborne radioactivity have been made in the area. Some of these results were discussed in Chapter 4. Another method of evaluating the potential contribution of resuspension of residual contamination in the areas is described here. The theoretical model selected is the straightforward mass-loading approach, which has been assessed as being suitable for conditions where the contaminant has been aged in the environment for some time (Ref. D16). Refinements to account for unequal distribution of the contaminant on different particle sizes and for the limited size of the contaminated area were included. The basic approach predicts the concentration of airborne activity (activity/unit volume of air) as the product of the mass of particulates in the air (mass/unit volume of air) and the concentration of activity in the soil (activity/unit mass of soil) in the area. This predicted air concentration is modified by an enrichment factor to account for the generally higher concentration per unit mass on smaller particles in the respirable range and for the generally small weight fraction of sma.l particles in soils.

The various parameters and the estimated airborne concentrations of ${ }^{239} \mathrm{Pu}$ for the individual areas are summarized in Table $\mathrm{D}$-V. The arithmetic mean ${ }^{239} \mathrm{Pu}$ soil concentrations carne from Tables XIV through XIX.

The enrichment factors for each area where particle size and activity distribution data were available were calculated as shown in Table D-VI. The enrichment ratio $g_{1}$ is the quotient of the activity fraction for a given particle size increment $i$ and the mass fraction for that size increment. These fractions were taken from or based on actual measurements of soils in the GZ and Chupadera Mesa areas as indicated by the references in the table. The airborne mass fraction $f_{1}$ for the size 
TABLE D-VI

\section{ENRICHMENT FACTORS FOR RESUSPENDABLE PARTICLES}

\begin{tabular}{|c|c|c|c|c|c|c|c|}
\hline Arca & $\begin{array}{c}\text { Size } \\
\text { Increment } \\
(\mu \mathrm{m}) \\
\end{array}$ & $\begin{array}{c}\text { Wt. } \\
\text { Fraction }\end{array}$ & $\begin{array}{l}{ }^{239} \mathrm{Pu} \\
\text { Activity } \\
\text { Fraction }\end{array}$ & $\begin{array}{c}\text { Activity } \\
\text { Mass } \\
\text { Ratio } \\
\mathrm{g}_{1} \\
\end{array}$ & $\begin{array}{c}\text { Airborne } \\
\text { Mass } \\
\text { Fraction } \\
\mathrm{f}_{\mathrm{f}}^{\mathrm{d}} \\
\end{array}$ & $\begin{array}{c}\text { Enrichment } \\
\mathbf{g}_{\mathrm{i}} \mathbf{f}_{\mathrm{i}} \\
\end{array}$ & $\Sigma g_{1} f_{1}$ \\
\hline \multirow[t]{2}{*}{ Trinity Site } & $53-105$ & $0.11^{\mathrm{a}}$ & $0.0043^{\mathrm{a}}$ & 0.039 & 0.35 & 0.014 & $\ldots$ \\
\hline & $<53$ & $0.089^{a}$ & $0.078^{a}$ & 0.088 & 0.65 & 0.057 & 0.071 \\
\hline \multirow[t]{2}{*}{ White Sands } & $53-105$ & $0.11^{\mathrm{b}}$ & $0.00+3^{\mathrm{b}}$ & 0.039 & 0.35 & 0.014 & $\cdots$ \\
\hline & $<53$ & $0.089^{b}$ & $0.078^{b}$ & 0.088 & 0.65 & 0.057 & 0.071 \\
\hline \multirow[t]{2}{*}{ Bingham } & $53-105$ & $0.19^{b}$ & $0.03^{b}$ & 0.16 & 0.35 & 0.056 & -- \\
\hline & $<53$ & $0.10^{\mathrm{b}}$ & $0.11^{\mathrm{b}}$ & 1.1 & 0.65 & 0.752 & 0.78 \\
\hline \multirow[t]{2}{*}{ Chupadera Mesa } & $53-105$ & $0.18^{b}$ & $0.16^{\mathrm{b}}$ & 0.89 & 0.35 & 0.31 & -.- \\
\hline & $<53$ & $0.36^{\mathrm{b}}$ & $0.73^{b}$ & 2.0 & 0.65 & 1.32 & 1.6 \\
\hline \multirow[t]{2}{*}{ Far Failout Zone } & $53-105$ & $0.18^{\mathrm{c}}$ & $0.16^{c}$ & 0.89 & 0.35 & 0.31 & -- \\
\hline & $<53$ & $0.36^{\mathrm{c}}$ & $0.73^{\mathrm{c}}$ & 2.0 & 0.65 & 1.32 & 1.6 \\
\hline \multirow[t]{2}{*}{ San Antonio } & $53-105$ & $0.18^{\mathrm{c}}$ & $0.16^{\mathrm{C}}$ & 0.89 & 0.35 & 0.31 & 31 \\
\hline & $<53$ & $0.36^{\mathrm{c}}$ & $0.73^{\mathrm{c}}$ & 2.0 & 0.65 & 1.32 & 1.6 \\
\hline
\end{tabular}

\footnotetext{
assumed to be the same as measured at $1.6 \mathrm{~km}$ location northeast of GZ.

${ }^{\mathrm{b}}$ Reference D14.

${ }^{\mathrm{C}}$ Assumed to be the same as measured at Chupadera Mesa.

${ }^{\mathrm{A}}$ Reference D13.
}

increment was taken from Fig. A2-3 in Ref. D13. The enrichment factor $\left(\Sigma_{1} f_{1} g_{1}\right)$ is the sum over the size increments of the respective $f_{1} g_{i}$ products.

The annual average mass loading was taken to be 24 $\mu \mathrm{g} / \mathrm{m}^{3}$ (Ref. D 16). This value is an annual geometric mean.

The estimated annual average ${ }^{239} \mathrm{Pu}$ air concentration is shown for each area. Table D-V also shows estimated annual average air concentrations for ${ }^{90} \mathrm{Sr}$ and ${ }^{137} \mathrm{Cs}$ for each area in which these isotopes occurred at concentrations on soil statistically above background as summarized in Table D-I as measurements had been made.
Potential doses that could result from the estimated air concentrations were calculated by using standard inhalation rates to determine intakes and appropriate dose conversion factors (Ref. D17). For dose estimation, the presence of transuranics other than ${ }^{239} \mathrm{Pu}$ (i.e., ${ }^{238} \mathrm{Pu}$, ${ }^{241} \mathrm{Pu}$, and ${ }^{241} \mathrm{Am}$ ) was accounted for by using a dose factor combining the effect of aging weapons grade plutonium for 50 years (Ref. D 18). Table D-VIl presents a summary of the dose factors for the first year and 50year committed dose equivalents for the isotopes and organs of interest. 
TABLE D-VII

INHALATION DOSE FACTORS USED

$(\mathrm{mrem} / \mu \mathrm{Ci})^{4}$

\begin{tabular}{|c|c|c|c|c|c|c|c|}
\hline \multirow[b]{2}{*}{ Radionuclides } & \multicolumn{3}{|c|}{ First Year Dose } & \multicolumn{4}{|c|}{$\begin{array}{l}\text { 50-Year Committed } \\
\text { Dose Equivalent }\end{array}$} \\
\hline & Whole Body & Bone & Lung & Whole Body & Bone & Lung & Liver \\
\hline Plutonium isotopes ${ }^{\mathrm{b}, c}$ & $2.3 \times 10^{2}$ & $8.3 \times 10^{3}$ & $5.3 \times 10^{4}$ & $8.7 \times 10^{4}$ & $9.0 \times 10^{3}$ & $9.4 \times 10^{3}$ & $4.5 \times 10^{5}$ \\
\hline${ }^{* u} \mathrm{Sr}$ & 8.3 & $1.9 \times 10^{2}$ & $7.0 \times 10^{2}$ & $7.6 \times 10^{2}$ & $1.2 \times 10^{4}$ & $1.2 \times 10^{3}$ & $\ldots$ \\
\hline${ }^{13} \mathrm{Cs}$ & $3.3 \times 10^{1}$ & $3.3 \times 10^{1}$ & 5.2 & $5.6 \times 10^{1}$ & $6.1 \times 10^{1}$ & 9.4 & $\cdots$ \\
\hline
\end{tabular}

Doses for transuranics were estimated as the product of the estimated average airborne ${ }^{239} \mathrm{Pu}$ concentrations for each stratum, a standard average breathing rate of 23 $\mathrm{m}^{3}$ day (from Ref. D 17), continuous ocsupancy, and the dose factors. These results are summarized in Table $D$ VIII by stratum for ${ }^{239} \mathrm{Pu}$ and total transuranics including ${ }^{239} \mathrm{Pu}$. Doses estimated for ${ }^{90} \mathrm{Sr}$ and ${ }^{137} \mathrm{Cs}$ are also shown in Table D-VIII. They are the products of the estimated resuspended air concentration attributable to soil contamination, the breathing rate, and the appropriate dose factor.

In the case of some air sampling data being available, the measured average for 10 months on Chupadera Mesa is $41 \mathrm{aCi} / \mathrm{m}^{3}$ (Ref. D 14), while the estimated resuspension by calculation is $120 \mathrm{aCi} / \mathrm{m}^{3}$. The estimated doses from inhalation are likely to be an overestimate.

\section{B. Ingestion of Radionuclides}

Dose calculations for ingested radionuclides considered the land use limitations of the areas of interest. Cattle grazing is the only land use out to the far fallout area. Beyond Chupadera Mesa, a few scattered fields of dry land wheat is raised, but the major land use is still cattle grazing. For the dose estimates here, the present land use assumes that all meat consumed, all milk products. and one-half the produce and vegetables are raised in the area being considered. The meat is further assumed to be all beef. Feed for the beef is assumed to be be by grazing or forage raised in the area of interest. The food intakes used are those listed in Table D-IX for the average individual. Other parameters used for the estimation of transfer of radionuclides through the food chain to man are listed in Table D-IX. Based on the feed crops available per unit area, the doses calculated for the inner fenced area and the area between fences at $G Z$ are overestimates. Not all of the food assumed to be consumed could be produced in the area available without altering present land use practices. The dose factors used for the calculations are listed in Table D-X.

1. Produce, Vegetables, and Forage. The transfer of radionuclides from soil to plants was estimated using the soil concentrations measured for the fallout areas in 1974 and 1977 listed in Tables XIV through XIX in Chapter 4. The GZ data for 1983 were used for plutonium isotopes. The plant transfer parameters used for ${ }^{239-240} \mathrm{Pu}$ were measured for GZ and Chupadera Mesa (Ref. D20). The concentration ratio (CR) between plant and soils was used for calculations at GZ and the White Sands Missile Range fallout area. The measured ${ }^{239-240} \mathrm{Pu} C R$ for Chupadera Mesa was used for the other fallout areas. The CRs listed in Table $\mathrm{D}-\mathrm{X}$ were used to calculate estimated radionuclide intake by beef and milk cows from forage and grazing. The produce and vegetable uptakes of radionuclides were estimated from the wet weight transfer parameter, $\mathrm{B}_{\mathrm{v}}$, and reduced $50 \%$ for removal of soils by washing. Estimated yearly radionuclide intakes from $50 \%$ locally grown produce and vegetables are listed in Table D-XI.

2. Beef and Milk Pathways. To estimate the amount of radionuclide intake by cattle, both the radionuclide transfer from soil to plant and direct consumption of soil were used. 
TABLE D-VIII

ESTIMATED DOSEY FROM INHALATION OF AIRBORNE MATERIALS FROM RESUSPENSION

Inhalation Dose in Area of Interest (mrem:-

\begin{tabular}{|c|c|c|c|c|c|c|c|}
\hline Dose Calculated for & $\begin{array}{c}\text { Trinity Site } \\
\text { Inner Fenced Area }\end{array}$ & $\begin{array}{c}\text { Trinity Site } \\
\text { Outer Fenced Area } \\
\end{array}$ & $\begin{array}{l}\text { White Sands } \\
\text { Missile Range }\end{array}$ & Bingham & $\begin{array}{c}\text { Chupadera } \\
\text { Mesa }\end{array}$ & $\begin{array}{c}\text { Far } \\
\text { Fallout Zone }\end{array}$ & $\begin{array}{c}\text { San } \\
\text { Antonio }\end{array}$ \\
\hline \multicolumn{8}{|l|}{ Transuranics } \\
\hline \multicolumn{8}{|l|}{ First Year Residence } \\
\hline Whole body & $7.3 \times 10^{-3}$ & $1.9 \times 10^{-3}$ & $4.2 \times 10^{-9}$ & $1.3 \times 10^{-5}$ & $2.3 \times 10^{-4}$ & $4.2 \times 10^{-1}$ & $1.4 \times 10^{-6}$ \\
\hline Bone & $2.6 \times 10^{-3}$ & $7.0 \times 10^{-4}$ & $1.5 \times 10^{-3}$ & $5.0 \times 10^{-1}$ & $8.4 \times 10^{-3}$ & $1.5 \times 10^{-3}$ & $5.1 \times 10^{-1}$ \\
\hline Lung & $1.2 \times 10^{-2}$ & $4.4 \times 10^{-3}$ & $9.8 \times 10^{-3}$ & $3.0 \times 10^{-3}$ & $5.3 \times 10^{-2}$ & $9.8 \times 10^{-3}$ & $3.0 \times 10^{-4}$ \\
\hline \multicolumn{8}{|c|}{ 50-Year Committed Dose } \\
\hline Whole body & $2.8 \times 10^{-1}$ & $07.3 \times 10^{-3}$ & $1.6 \times 10^{-2}$ & $4.9 \times 10^{-3}$ & $8.8 \times 20^{-2}$ & $1.6 \times 10^{-2}$ & $5.0 \times 10^{-4}$ \\
\hline Bone & 0.29 & $7.4 \times 10^{-2}$ & 0.17 & $5.1 \times 10^{-1}$ & 0.91 & 0.17 & $5.5 \times 10^{-3}$ \\
\hline Lung & 0.30 & $7.7 \times 10^{-2}$ & 0.17 & $5.3 \times 10^{-2}$ & 0.95 & 0.17 & $5.8 \times 10^{-3}$ \\
\hline Liver & 0.14 & $3.7 \times 10^{-2}$ & $8.3 \times 10^{-2}$ & $2.5 \times 10^{2}$ & 0.45 & $8.3 \times 10^{-2}$ & $2.8 \times 10^{3}$ \\
\hline \multicolumn{8}{|l|}{${ }^{\infty} \mathrm{Sr}$} \\
\hline \multicolumn{8}{|l|}{ Firs! Year Residence } \\
\hline Whole body & $\cdots$ & $\ldots$ & $2.1 \times 10^{-7}$ & -.. & $6.1 \times 10^{-6}$ & $3.9 \times 10^{-6}$ & $\ldots$ \\
\hline Bone & $\ldots$ &.-- & $3.1 \times 10^{-6}$ & $\cdots$ & $8.9 \times 10^{-1}$ & $5.6 \times 10^{-9}$ & $\cdots$ \\
\hline Lung & --- & -- & $1.8 \times 10^{-5}$ & $\cdots$ & $5.0 \times 10^{-4}$ & $3.0 \times 10^{-4}$ & $\cdots$ \\
\hline \multicolumn{8}{|c|}{ 50-Year Committed Dose } \\
\hline Whole body & $\cdots$ & -.. & $2.0 \times 10^{-3}$ & $-\cdots$ & $6.0 \times 10^{-4}$ & $4.0 \times 10^{-4}$ & $\cdots$ \\
\hline Bone & $\cdots$ & $\ldots$ & $3.1 \times 10^{-4}$ & $\ldots$ & $8.9 \times 10^{-3}$ & $5.6 \times 10^{-3}$ & $\ldots$ \\
\hline Lung & -.. & $\ldots$ & $3.1 \times 10^{-9}$ &.-- & $8.9 \times 10^{-4}$ & $5.6 \times 10^{-4}$ & $\ldots$ \\
\hline \multicolumn{8}{|l|}{${ }^{137} \mathrm{Cs}$} \\
\hline \multicolumn{8}{|l|}{ First Year Residence } \\
\hline Whole body & $7.8 \times 10^{-6}$ & $2.5 \times 10^{-7}$ & $5.0 \times 10^{-7}$ & $1.9 \times 10^{-9}$ & $3.0 \times 10^{-5}$ & $2.1 \times 10^{-3}$ & $5.0 \times 10^{-5}$ \\
\hline Bone & $7.8 \times 10^{-6}$ & $2.5 \times 10^{-7}$ & $5.0 \times 10^{-7}$ & $1.9 \times 10^{-9}$ & $3.0 \times 10^{-9}$ & $2.1 \times 10^{-3}$ & $5.0 \times 10^{-3}$ \\
\hline Lung & $1.2 \times 10^{-6}$ & $4.0 \times 20^{-1}$ & $7.9 \times 10^{-8}$ & $3.0 \times 10^{-6}$ & $4.8 \times 10^{-6}$ & $3.4 \times 10^{-6}$ & $7.8 \times 10^{-6}$ \\
\hline \multicolumn{8}{|c|}{ 50. Year Committed Dose } \\
\hline Whole body & $1.3 \times 10^{-9}$ & $4.3 \times 10^{-7}$ & $8.5 \times 10^{-7}$ & $3.2 \times 10^{-3}$ & $5.2 \times 10^{-9}$ & $3.6 \times 10^{-5}$ & $8.5 \times 10^{-5}$ \\
\hline Bone & $1.4 \times 10^{-3}$ & $4.3 \times 10^{-7}$ & $8.5 \times 10^{7}$ & $3.2 \times 10^{-9}$ & $5.2 \times 10^{-5}$ & $3.6 \times 10^{-9}$ & $8.5 \times 10^{-5}$ \\
\hline Lung & $2.2 \times 10^{-6}$ & $7.2 \times 10^{-3}$ & $1.4 \times 10^{-7}$ & $5.4 \times 10^{-6}$ & $8.7 \times 10^{-6}$ & $6.1 \times 10^{-6}$ & $1.4 \times 10^{-9}$ \\
\hline \multicolumn{8}{|l|}{$\begin{array}{l}\text { Totals for Inhalation } \\
\text { First Year Residence }\end{array}$} \\
\hline Whole body & $8.1 \times 10^{-5}$ & $1.9 \times 10^{-3}$ & $4.3 \times 10^{-3}$ & $3.2 \times 10^{-5}$ & $2.3 \times 10^{-4}$ & $6.7 \times 10^{-9}$ & $5.1 \times 10^{-5}$ \\
\hline Bone & $2.6 \times 10^{-3}$ & $3.0 \times 10^{-4}$ & $1.5 \times 10^{-3}$ & $5.2 \times 10^{-4}$ & $8.4 \times 10^{-3}$ & $1.5 \times 10^{-3}$ & $1.0 \times 10^{-4}$ \\
\hline Lung & $1.7 \times 10^{-2}$ & $4.4 \times 10^{-3}$ & $9.8 \times 10^{-1}$ & $3.0 \times 10^{-3}$ & $5.3 \times 10^{-1}$ & $1.0 \times 10^{-2}$ & $3.0 \times 10^{-4}$ \\
\hline \multicolumn{8}{|c|}{ 50-Year Committed Dose } \\
\hline Whole body & $2.8 \times 10^{-2}$ & $7.3 \times 10^{-3}$ & $1.6 \times 10^{2}$ & $4.9 \times 10^{-3}$ & $8.8 \times 10^{-2}$ & $1.6 \times 10^{-2}$ & $5.8 \times 10^{-4}$ \\
\hline Bene & 0.29 & $7.4 \times 10^{-2}$ & 0.17 & $5.1 \times 10^{-2}$ & 0.91 & 0.17 & $5.6 \times 10^{-1}$ \\
\hline Lung & 0.30 & $7.7 \times 10^{-2}$ & 0.17 & $5.3 \times 10^{-2}$ & 0.95 & 0.17 & $5.8 \times 10^{-1}$ \\
\hline Liver & 0.14 & $3.7 \times 10^{-2}$ & $8.3 \times 10^{-2}$ & $2.5 \times 10^{-2}$ & 0.45 & $8.3 \times 10^{2}$ & $2.8 \times 10^{-3}$ \\
\hline
\end{tabular}

\footnotetext{
meins no diala.
} 
TABLE D-IX

INPUT PARAMETERS FOR DOSE CALCULATIONS"

Breathing Rate

Ingestion Rates

Prixuce (kg/yr)

Leafy vegetables $(\mathrm{kg} / \mathrm{yr})$

Milk (R/yr)

\section{Average Agricultural Pro- ductivity per Unit Area}

Feed crops $\left(\mathrm{kg} / \mathrm{m}^{2}\right)$ (dry weight)

Produce or leafy vegetables

for garden of maximum

exposed individual

$\left(\mathrm{kg} / \mathrm{m}^{2}\right.$ ) (wet weight)

Consumption rate of feed by

animal ( $\mathrm{g} / \mathrm{day})$ (dry weight)

Fraction of radioactivily re-

moved from plant by washing

Soil ingested by cattle

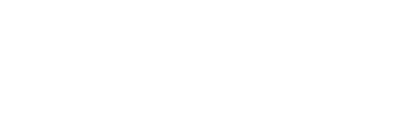

Transfer Parameters'

\begin{tabular}{|c|c|c|c|c|c|c|}
\hline \multirow[b]{2}{*}{ Transfer Parameters ${ }^{\mathrm{c}}$} & \multicolumn{2}{|c|}{ Plutonium } & \multirow[b]{2}{*}{ Strontium } & \multirow[b]{2}{*}{ Cesium } & \multirow[b]{2}{*}{ Europium } & \\
\hline & GZ & Chupadera & & & & \\
\hline$F_{\mathrm{ra}}$ & $1.0 \times 10^{-1}$ & $1.0 \times 10^{7}$ & $1.4 \times 10^{-1}$ & $71 \times 10^{-7}$ & $2.0 \times 10^{9}$ & (Ref. $i: 26$ ) \\
\hline$F_{F}$ & $1.0 \times 10^{\circ}$ & $1.0 \times 10^{-1}$ & $3.0 \times 10^{-4}$ & $2.0 \times 10^{-2}=$ & $5.0 \times 10^{1}$ & (Ref, ;.?7) \\
\hline $\mathrm{CR}^{\mathrm{d}}$ & $5 \times 10^{-2}$ & $1.1 \times 10^{11}$ & $1.8 \times 10^{\mathrm{h}}$ & $4.1 \times 10=$ & $2.1 \times 10^{2}=$ & (Refs: :20, D28) \\
\hline B. & $1.2 \times 10^{-2}$ & $2.7 \times 10^{1}$ & $7.2 \times 10^{2}$ & $5.0 \times 10^{-3}$ & $7.3 \times 10^{4}$ & (Refs. 20,028$)$ \\
\hline
\end{tabular}

$22.8 \mathrm{~m}^{3} /$ day

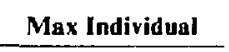

Population

(Average Iıdividual)

176

18

112

310

Chupadera

0.043

Other

0.056

2.0

$11.9^{\mathrm{h}}$

0.5

250
2.0

0.5

250
(Ref. DI8)

(Refs. D21. D22)

(Ref. D22)

(Ref. 23)

(Ref. D24)

(Ref. D25)

Radionuclides

\section{ARef. D29.}

"rfaken as $2.5 \%$ of body weight. where the average live weight of cattle at slaughter of $477 \mathrm{~kg}$ was used

${ }^{\prime} F_{M}=$ fraction of each day's radionuclide intake appearing in each liter of milk. $F_{F}=$ fraction of each day's radionucide intake appearing in $1 ; \cdots ;$; kilogram of nesh, $C R=$ concentration ratio for radionuclide uptake from soil to pasture or feed ( $\mathrm{pCi} / \mathrm{kg}$ dry weight per $\mathrm{pC} / \mathrm{kg}$ dry soil). and $\mathrm{B}$, = concen radionuclide uptake from soil to edible parts of vegetatle crops $(\mathrm{pCi} / \mathrm{kg}$ wet weight per $\mathrm{pCi} / \mathrm{kg}$ dry soil).

"Plutonium CR basea on measurements by Hakonson. 
Experiments at contaminated zones of the Nevada Test Site have indicated that cattle ingest about $250 \mathrm{~g} / \mathrm{d}$ of soil while grazing (Ref. D24). Transfer of the radionuclides from the cattle's diet into milk and meat were estimated using the factors lited in Table D-X. Estimates of the amount of radionuclides consumed yearly by humans in meat and milk are listed by area in Table $D$ XI.

3. Dose Estimates from Ingestion. The total intakes of ${ }^{139,240} \mathrm{Pu},{ }^{40} \mathrm{Sr},{ }^{137} \mathrm{Cs}$, and ${ }^{152}$ Eu from consumption of beef, milk, and home garden products are listed in Table D-XI. The product of these values and the dose factors in Table $\mathrm{D}$-X provide the maximum year dose and the 50 -ycar committed dose equivalent for whole body, bone, liver, and the lower large intestine. The results of these calculations are listed in Table D-XII.

\section{Special Pathways}

The above dose estimates assume human activities that do not create any special considerations of sources of radionuclide intake. However, to grow $50 \%$ of their produce and vegetables, individuals would have to go through soil preparation activities. Measurements made during soil preparation activities indicate higher resuspension rates than normally encountered (Ref. D30). To estimate the dose to the home gardener requires some broad assumptions regarding breathing rate, suspended particle concentration, enrichment factor, dose factors, and appropriate soil concer ${ }_{2}$ ation. The breathing rate used for this type of work was $43 \mathrm{l} / \mathrm{min}$, or that for heavy work (Ref. D 17). Air concentrations were assumed to be $10 \mathrm{mg} / \mathrm{m}^{3}$, the threshold for nuisance dust. Enrichment factors from Table D-VI were used. Soil concentrations used are the mean values of the summary data for $0-5$, 5-10, and 10-15-cm soil samples in Chapter 4. The soil preparation time was assumed to be $30 \mathrm{~h}$ for a growing season. The parametcrs used are presented in Table DXII! and estimated doses in Table D-XIV.

TABLE D-X

INGESTION DOSE FACTORS USED

\begin{tabular}{|c|c|c|c|c|c|c|}
\hline \multirow[b]{2}{*}{ Radionuclide } & \multicolumn{2}{|c|}{$\begin{array}{l}\text { Maximum Year Dose } \\
[(\mathrm{mrem} / \mathrm{yr})(\mathrm{pCi}) / \mathrm{g} \text { soii })]^{\mathrm{a}}\end{array}$} & \multicolumn{4}{|c|}{ 50-Year Committed Dose Equivalent (nrem/pCi) } \\
\hline & Whole Body & Bone & Whole Body & Bone & Liver & GI-LLI \\
\hline Plutonium isotopes ${ }^{b}$ & c & 0.45 & $c$ & $7.8 \times 10^{-4}$ & $3.4 \times 10^{-4}$ & $c$ \\
\hline${ }^{90} \mathrm{Sr}^{\mathrm{d}}$ & $\mathrm{c}$ & 5 & $9.45 \times 10^{-5}$ & $1.17 \times 10^{-3}$ & $5.7 \times 10^{-5}$ & $7.78 \times 10^{-5}$ \\
\hline${ }^{137} \mathrm{Cs}^{\mathrm{d}}$ & 0.63 & $\mathrm{c}$ & $4.91 \times 10^{-5}$ & $6.82 \times 10^{-5}$ & $7.87 \times 10^{-5}$ & $2.59 \times 10^{-5}$ \\
\hline${ }^{152} \mathrm{Eu}^{\mathrm{d}}$ & $\cdots$ & $\cdots$ & $3.9 \times 10^{-8}$ & $2.0 \times 10^{-7}$ & $4.4 \times 10^{-8}$ & $2.6 \times 10^{-5}$ \\
\hline
\end{tabular}


TABLE D-XI

INGESTED RADIONUCLIDES $(\mathrm{pCi} / \mathrm{yr})^{\mathrm{a}}$

\begin{tabular}{|c|c|c|c|c|c|c|c|}
\hline \multirow[b]{2}{*}{ Radionuclide and Medium } & \multicolumn{7}{|c|}{ Areg of Interest } \\
\hline & $\begin{array}{l}\text { Trinity Site } \\
\text { Inner Fence }\end{array}$ & $\begin{array}{c}\text { Trinity Site } \\
\text { Between Fences }\end{array}$ & $\begin{array}{l}\text { White Sands } \\
\text { Missile Range }\end{array}$ & Bingham & $\begin{array}{l}\text { Chupadera } \\
\text { Mesa }\end{array}$ & $\begin{array}{c}\text { Far } \\
\text { Fallout Zone }\end{array}$ & $\begin{array}{c}\text { San } \\
\text { Antonio }\end{array}$ \\
\hline \multicolumn{8}{|l|}{ Transuranics } \\
\hline Produce and vegetables & $9.1 \times 10^{4}$ & $3.4 \times 10^{3}$ & $5.8 \times 10^{3}$ & $4.6 \times 10^{3}$ & $2.2 \times 10^{4}$ & $3.9 \times 10^{3}$ & $1.3 \times 10^{2}$ \\
\hline Milk & 1.46 & 0.055 & 0.095 & 0.052 & 0.25 & 0.045 & 0.0055 \\
\hline Bief & 12.2 & 0.46 & 0.79 & 0.44 & 2.12 & 0.38 & 0.012 \\
\hline $\begin{array}{l}\text { Total intake } \\
{ }^{90} \mathrm{Sr}\end{array}$ & $9.1 \times 10^{4}$ & $3.4 \times 10^{3}$ & $5.8 \times 10^{3}$ & $\overline{4.6 \times 10^{3}}$ & $2.2 \times 10^{4}$ & $29 \times 10^{3}$ & $1.3 \times 10^{2}$ \\
\hline Produce and Vegetables & c & c & $6.3 \times 10^{3}$ & c & $8.0 \times 10^{3}$ & $5.2 \times 10^{3}$ & c \\
\hline Milk & c & c & $6.1 \times 10^{3}$ & c & $7.8 \times 10^{3}$ & $5.1 \times 10^{3}$ & c \\
\hline Beef & c & c & $1.10 \times 10^{3}$ & c & $1.4 \times 10^{3}$ & $9.2 \times 10^{2}$ & $\mathrm{c}$ \\
\hline $\begin{array}{l}\text { Total intake } \\
{ }^{137} \mathrm{Cs}\end{array}$ & c & c & $1.3 \times 10^{4}$ & c & $1.7 \times 10^{4}$ & $1.1 \times 10^{4}$ & c \\
\hline Produce and vegetables ${ }^{b}$ & $5.3 \times 10^{3}$ & $1.6 \times 10^{2}$ & $1.1 \times 10^{3}$ & $9.0 \times 10^{2}$ & $6.8 \times 10^{2}$ & $4.8 \times 10^{2}$ & $2.2 \times 10^{2}$ \\
\hline Milk & $1.3 \times 10^{4}$ & $3.8 \times 10^{2}$ & $2.6 \times 10^{3}$ & $2.2 \times 10^{3}$ & $1.6 \times 10^{3}$ & $1.2 \times 10^{3}$ & $5.4 \times 10^{2}$ \\
\hline Beef & $3.1 \times 10^{4}$ & $8.9 \times 10^{2}$ & $6.2 \times 10^{3}$ & $5.1 \times 10^{3}$ & $3.9 \times 10^{3}$ & $2.8 \times 10^{3}$ & $1.3 \times 10^{3}$ \\
\hline $\begin{array}{l}\text { Tot intake } \\
{ }^{152} \mathrm{Eu}\end{array}$ & $4.9 \times 10^{4}$ & $1.4 \times 10^{3}$ & $9.9 \times 10^{3}$ & $8.2 \times 10^{3}$ & $6.2 \times 10^{3}$ & $4.5 \times 10^{3}$ & $2.1 \times 10^{3}$ \\
\hline Produce and vegetables & $8.7 \times 10^{3}$ & $7.1 \times 10^{2}$ & $1.9 \times 10^{2}$ & c & 1.1 & c & $\mathrm{c}$ \\
\hline Milk & $2.7 \times 10^{2}$ & $2.2 \times 10^{1}$ & 6.0 & c & 0.034 & c & c \\
\hline Beef & $8.6 \times 10^{3}$ & $7.1 \times 10^{2}$ & $1.9 \times 10^{2}$ & $\mathrm{c}$ & 1.1 & $\mathrm{c}$ & $c$ \\
\hline Total intake & $1.7 \times 10^{4}$ & $1.4 \times 10^{3}$ & $3.8 \times 10^{2}$ & $\overline{\mathrm{c}}$ & 2.2 & c & c \\
\hline
\end{tabular}

astimated for average individual in population.

bFifty per cent of produce and vegetables are grown locally in yardens.

${ }^{\mathfrak{c}}$ Not calculated because no soil data were available. 
TABLE D-XII

ESTIMATED DOSES FROM INGESTION OF FOODS GROWN IN EACH AREA

Ingestion Dose in Area of Interest (mrem/yr)

\begin{tabular}{|c|c|c|c|c|c|c|c|}
\hline Dose Calculated & $\begin{array}{l}\text { Trimity Site } \\
\text { Inner Fence }\end{array}$ & $\begin{array}{l}\text { Trinity Site } \\
\text { Outer Fence }\end{array}$ & $\begin{array}{l}\text { White Sands } \\
\text { Missile Range }\end{array}$ & Binghsm & $\begin{array}{c}\text { Chupadera } \\
\text { Mesa }\end{array}$ & $\begin{array}{c}\text { Far } \\
\text { Fallout Zone }\end{array}$ & $\begin{array}{c}\text { San } \\
\text { Antonio }\end{array}$ \\
\hline \multicolumn{8}{|l|}{ Transuranics } \\
\hline \multicolumn{8}{|l|}{ Maximum year } \\
\hline Bone & 70 & 2.6 & 4.5 & 3.6 & 17 & 3.0 & 0.1 \\
\hline \multicolumn{8}{|c|}{ 50-Year Committed Dose } \\
\hline Whole body & . & ! & . & - & , & - & - \\
\hline bone & 71 & 2.6 & 4.5 & 3.6 & 17 & 3.0 & 0.1 \\
\hline Liver & 31 & 1.2 & 2.0 & 1.6 & 7.5 & 1.3 & 0.04 \\
\hline GI-LLI' & , & . & . & $\bullet$ & : & , & ' \\
\hline \multicolumn{8}{|l|}{${ }^{90} \mathrm{Sr}_{\mathrm{r}}$} \\
\hline \multicolumn{8}{|l|}{ Maximum Year } \\
\hline Bone & - & - & 9 & $g^{c}$ & 11.5 & 7.5 & ' \\
\hline \multicolumn{8}{|c|}{ 50-Year Committed Dose } \\
\hline Whole body & - & - & 1.2 & $1.2^{\mathrm{c}}$ & 1.6 & 1.0 & 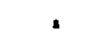 \\
\hline Bone & $\cdot$ & - & 15 & $15^{c}$ & 20 & 13 & • \\
\hline Liver & - & . & 0.07 & $0.07^{c}$ & 0.09 & 0.06 &. \\
\hline Gl-LLI & - & . & 1.0 & $1.0^{x}$ & 1.3 & 0.9 & - \\
\hline \multicolumn{8}{|l|}{${ }^{137} \mathrm{Cs}$} \\
\hline \multicolumn{8}{|l|}{ Maximum Year } \\
\hline Whole body & 14 & 0.4 & 2.8 & 2.3 & 1.8 & 1.3 & 0.6 \\
\hline \multicolumn{8}{|c|}{ 50-Year Committed Dose } \\
\hline Whole body & 2.4 & 0.1 & 0.5 & 0.4 & 0.3 & 0.2 & 0.1 \\
\hline Bone & 3.4 & 0.1 & 0.7 & 0.6 & 0.4 & 0.3 & 0.1 \\
\hline Liver & 3.8 & $0 . \hat{\mathbf{i}}$ & 0.8 & 0.6 & 0.5 & 0.4 & 0.2 \\
\hline Gl-LLI & 1.3 & 0.03 & 0.3 & 0.2 & 0.2 & 0.1 & 0.05 \\
\hline \multicolumn{8}{|c|}{${ }^{192} \mathrm{Eu}$} \\
\hline \multicolumn{8}{|c|}{ 50-Year Committed Dose } \\
\hline Whole body & $7 \times 10^{-4}$ & $5 \times 10^{-3}$ & $1 \times 10^{-5}$ & 9 & - & 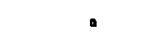 & : \\
\hline Bone & $3 \times 10^{-3}$ & $3 \times 10^{-4}$ & $8 \times 10^{-5}$ & - & • & - & $\cdot$ \\
\hline Liver & $7 \times 10^{-4}$ & $6 \times 10^{-9}$ & $2 \times 10^{-9}$ & 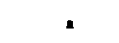 & - & $\cdot$ & 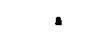 \\
\hline GI-LLI & 0.4 & $4 \times 10^{-2}$ & $\bullet$ & - & - & - & • \\
\hline \multicolumn{8}{|l|}{ Totals for İngestion } \\
\hline \multicolumn{8}{|l|}{ Maximum Year } \\
\hline Whole body & 14 & 0.4 & 2.8 & 2.3 & 1.8 & 1.3 & 0.6 \\
\hline Bone & -- & -.- & 13.5 & --- & 28 & 11 & $-\cdots$ \\
\hline \multicolumn{8}{|c|}{ so-Year Committed Dose } \\
\hline Whole body & 2.4 & 0.1 & 1.7 & 1.6 & 1.9 & 1.2 & 0.1 \\
\hline Bone & 74 & 2.7 & 20 & 19 & 37 & 16 & 0.2 \\
\hline Liver & 35 & 1.3 & 2.9 & 2.3 & 8.1 & 1.8 & 0.2 \\
\hline GI-LLI & 1.3 & 0.03 & 1.3 & 1.2 & 1.5 & 1.0 & 0.05 \\
\hline
\end{tabular}

Not calculated.

GGastrointestinal tract-large intestine.

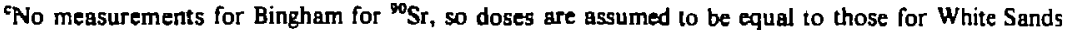

Missile Range. 
TABLE D-XIII

ESTIMATED AIR CONCENTRATION FOR SOIL PREPARATION FOR HOME GARDEN ${ }^{\natural}$

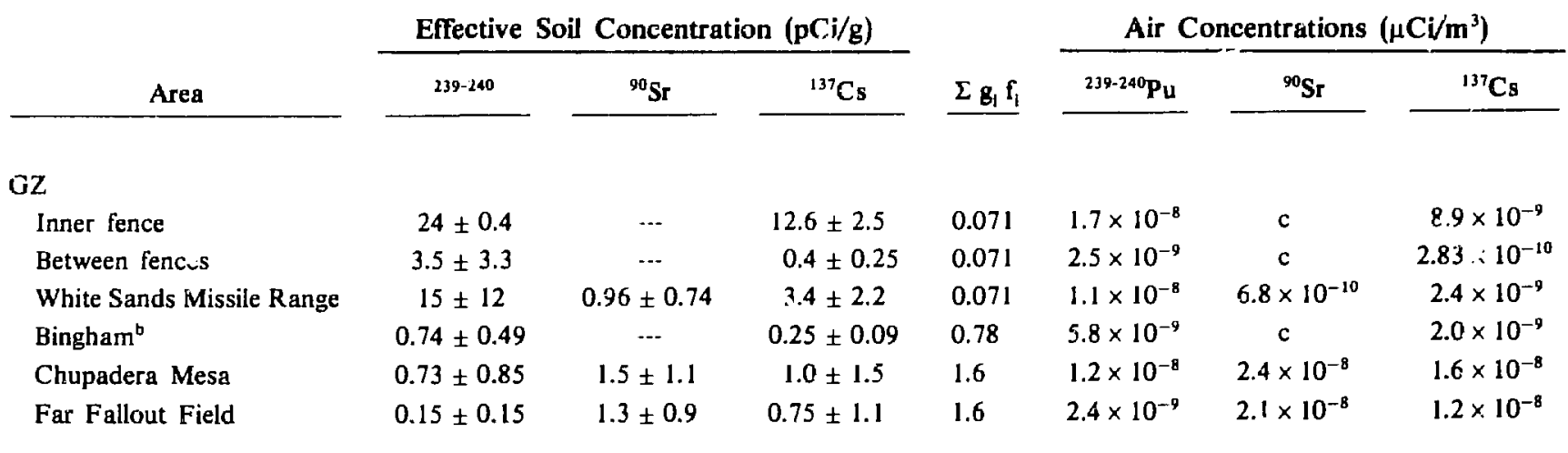

${ }^{8}$ Dust loading of $10000 \mu \mathrm{g} / \mathrm{m}^{3}$.

bestimated from area measurements.

"Not calculated. 


\section{ESTIMATE DOSES FROM SOIL PREPARATION FOR HUME GARDEN"}

\begin{tabular}{|c|c|c|c|c|c|c|}
\hline \multirow[b]{2}{*}{ 50-Yr Committed Doses for } & \multicolumn{6}{|c|}{ Inhalation Dose (mrem/yr) } \\
\hline & $\begin{array}{c}\text { GZ } \\
\text { Inner Fence }\end{array}$ & $\begin{array}{c}\text { GZ } \\
\text { Between Fences }\end{array}$ & $\begin{array}{l}\text { White Sands } \\
\text { Missile Range }\end{array}$ & Bingham & $\begin{array}{c}\text { Chupadera } \\
\text { Mesa } \\
\end{array}$ & $\begin{array}{c}\text { Far } \\
\text { Fallout Zone }\end{array}$ \\
\hline \multicolumn{7}{|l|}{ Transuranics } \\
\hline Whole body & 0.11 & 0.017 & 0.073 & 0.039 & 0.082 & 0.016 \\
\hline Bone & 1.2 & 0.17 & 0.76 & 0.40 & 0.84 & $0 ; 17$ \\
\hline Lung & 1.2 & 0.18 & 0.80 & 0.42 & 0.87 & 0.17 \\
\hline Liver & 0.59 & 0.086 & 0.38 & 0.20 & 0.42 & 0.084 \\
\hline \multicolumn{7}{|l|}{${ }^{90} \mathrm{Sr}$} \\
\hline Whole body & b & b & $4.0 \times 10^{-5}$ & b & $1.4 \times 10^{-3}$ & $1.2 \times 10^{-3}$ \\
\hline Bone & b & $\mathrm{b}$ & $6.0 \times 10^{-4}$ & b & $2.2 \times 10^{-2}$ & $2.0 \times 10^{-2}$ \\
\hline Lung & b & $b$ & $6.3 \times 10^{-3}$ & $b$ & $2.2 \times 10^{-3}$ & $2.0 \times 10^{-3}$ \\
\hline \multicolumn{7}{|l|}{${ }^{137} \mathrm{Cs}$} \\
\hline Whole body & $3.8 \times 10^{-5}$ & $1.2 \times 10^{-6}$ & $1.0 \times 10^{-3}$ & $8.7 \times 10^{-6}$ & $6.9 \times 10^{-9}$ & $5.2 \times 10^{-5}$ \\
\hline Bone & $4.2 \times 10^{-5}$ & $1.3 \times 10^{-6}$ & $1.1 \times 10^{-5}$ & $9.4 \times 10^{-6}$ & $7.5 \times 10^{-5}$ & $5.7 \times 10^{-5}$ \\
\hline Lung & $6.5 \times 10^{-6}$ & $2.0 \times 10^{-7}$ & $1.7 \times 10^{-6}$ & $1.4 \times 10^{-6}$ & $1.1 \times 10^{-5}$ & $8.7 \times 10^{-6}$ \\
\hline \multicolumn{7}{|l|}{ Totals } \\
\hline Whole body & 0.11 & 0.017 & 0.073 & 0.039 & 0.083 & 0.017 \\
\hline Bone & 1.2 & 0.17 & 0.76 & 0.40 & 0.86 & 0.19 \\
\hline Lung & 1.2 & 0.18 & 0.80 & 0.42 & 0.87 & 0.17 \\
\hline Liver & 0.59 & 0.086 & 0.38 & 0.20 & 0.42 & 0.086 \\
\hline
\end{tabular}

${ }^{a}$ Assumptions are breathing rate of $43 \mathrm{l} / \mathrm{min}$ for $30 \mathrm{~h} / \mathrm{yr}$.

${ }^{\mathrm{b}}$ Not calculated. 


\section{REFERENCES}

D1. W. D. Purtymun, R. J. Peters, and A. K. Stoker, "Radioactivity in Soils and Sediments in and Adjacent to the Los Alamos Area, 1974-1977," Los Alamos Scientific Laboratory report LA-8234-MS (February 1980).

D2. Environmental Surveillance Group, "Environmental Surveillarice at Lus Alamos During 1978," Los Alamos Scientific Laboratory report LA-7800ENV (April 1979).

D3. U.S. Department of Energy, "Radiological Survey of the Bayo Canyon. Los Alamos, New Mexico." Los Alamos National Laboratory report DOE/EV-0005/15 (June 1979).

D4. A. J. Ahlquist, A. K. Stoker, and L. K. Trocki, compilers, "Radiological Survey and Decontamination of the Former Main Technical Area (TA-1) at Los Alamos, New Mexico," Los Alamos Scientific Laboratcry report LA-6887 (December 1977).

D5. L. D. P. King. "Ground Activity After the Trinity Shot," Los Alamos Scientific Laboratory report LA-658-MS (December 1947).

D6. P. Aebersold and P. B. Moon, "July 16th Nuclear Explosion: Radiation Survey of Trinity Site Four Weeks after Explosion," Lus Alamos Scientific Laboratory report LA-359 (September 1945).

D7. F. Reines, "July 16: amination of Tower Focting," Los Alamos Scientific Laboratory repor! LA-365A (November 1945).

[08. Cliarles D. Blackwell, memorandum to Dean D. Meyer, "Preliminary Report of Surveys and Cleanup Program at Trinity Site from March 14, 1967 through April 17, 1967," Lcs Alamos Scientific Laboratory (April 17, 1967).

D9. G. P. Kraker, memorardum: "Decontamination of Trinity Site," U.S. Atomic Energy Commission (June 1951).
D10. F. L. Fey, Jr., "Health Physics Survey of Trinity Site," Los Alamos Scientific Laboratory report LA-3719 (July 1967).

D11. U.S. Department of Energy, "Radiological Guidelines for Application to DOE's Formerly Utilized Sites Remedial Action Program," U.S. DOE, Oak Ridge Operations report ORO-831 (March 1983).

D12. U.S. Environmental Protection Agency, "Persons Exposed to Transuranium Elements in the Environment: Federal Radiation Protection Guidance on Dose Limits," Federal Register, Vol. 42, No. 230, November 30, 1977, pp. 60956-60959 (1977).

D13. J. W. Nyhan, F. R. Miera, Jr., and R. E. Neher, "Distribution of Plutonium in Trinity Soils after 28 Years," Journal of Environmental Quality, Vol. 5, No. 4, pp. $431-437$ (1976).

D14. Richard L. Douglas, "Level and Distribution of Environmental Plutorium Around the Trinity Site," U.S. Environmental Protection Agency, Office of Radiation Programs report ORP/LV-78-3 (October 1978).

D15. W. J. Wenzel and A. F. Gallegos, "Supplementary Documentation for an Environmental Impact Statement Regarding the Pantex Plant: Long-Term Radiological Risk Assessment for Postulated Accidents," Los Alamos National Laboratory report LA-9445-PNTX-O (December 1982).

D16. U.S. Environmental Protection Agency, "Proposed Guidance on Dose Limits for Persons Exposed to Transuranium Elements in the General Environment," U.S. Environmental Protection Agency, Office of Radiation Programs report EPA 540/4-77-016 (September 1977).

D17. International Commission on Radiological Protection, "Report of the Task Group on Reference Man," International Commission on Radiological Protection Publication 23 (October 1974). 
D 18. T. Buhl, J. Dewart, T. Gunderson, D. Talley, J. Wenzel, R. Romero, J. Salazar, and D. Van Etten, "Supplementary Documentation for an Environmental Impact Statement Regarding the Pantex Plant: Radiation Monitoring and Radiological Assessment of Routine Releases," Los Alamos National Laboratory report LA-9445-PNTX-C (December 1982).

D19. Alan K. Stoker, "Radiological Survey of the Site of a Former Radioactive Liquid Waste Treatment Plant (TA-45) and the Effluent Receiving Areas of Acid, Pueblo, and Los Alamos Canyons, Los Alamos. New Mexico," Los Alamos National Laboratory report DOE/EV-0005/30, LA-8890ENV (Mav 1981).

D20. Y. C. Ng, C. S. Colsher, and S. E. Thompson,"Soil to Plant Concentration Factors for Radiols jical Assessments," U.S. Nuclear Regulatory Cu" . mission report NUREG/CR-2975, UCID-1946j (November 1982).

D21. R. E. Moore. C. F. Baes III, L. M. McDowellBoyer, A. P. Watson, F. O. Hoffman, J. C. Pleasant, and C. W. Miller, "AIRDOS-EPF, A Computerized Methodology for Estimating Environmental Concentrations and Dose to Man from Airborne Releases of Kadionuclides," Oak Ridge National Laboratory report ORNL-5532 (1979).

D22. U.S. Nuclear Regulatory Commission, "Calculational Models for Estimating Radiation Doses to Man from Airborne Radioactive Materials Resulting from Uranium Milling Operations," U.S. Nuclear Regulatory Commission Regulatory Guide 3.51 (March 1982).

D23. Y. C. Ng, C. S. Colsher, D. J. Quinn, and S. E. Thompson, "Transfer Coefficients for the Prediction of the Dose to Man via the Forage-Cow-Milk Pathway from Radionuclides Released to the Biosphere," Lawrence Livermore National Laboratory report UCRL-51939 (July 1977).
D24. W. E. Martin and S. G. Bloom, "Nevada Applicd Ecology Group Model for Estimating Plutonium Transport and Dose to Man," in "Transuranics in Natural Environments," M. G. White and P. B. Dunaway, eds., Energy Research and Development Administration report NVO-178, pp. 621-706 (October 1976).

D25. R. W. Shor, C. F. Baes III, and R. D. Sharp, "Agricultural Production in the United States by County: A Compilation of Information from the 1974 Census of Agriculture for Use in Terresirial Food-Chain Transport and Assessment Models," Oak Ridge National Laboiatory report ORNL-5768 (January 1982).

D26. Y. C. Ng, C. S. Colsher, and S. E. Thompson, "Transfer Factors for Assessing the Dose from Radionuclides in Agriculturai Products," Lawrence Livermore National Laboratory preprint UCRL-82545 (June 1979).

D27. T. E. Hakonson and J. W. Nyhan, "Ecological Relationships of Plutonium in Southwest Ecosystems," in "Transuranic Elements in the Environment," W. C. Hanson, ed., U.S. Department of Energy report DOE/TIC-22800, pp. 403-419 (1980).

D28. J. W. Heäiy, J. C. Rodgers, and C. L. Wienke, "Interim Limits for D\&D Projects," Los Alamos National Laboratory document LA-UR-79-1865 Rev (September 1979).

D29. U.S. Nuclear Regulatoiy Commission, "Calculation of Annual Doses to Man from Routine Re leases of Reactor Effluents for the Purpose of Evaluating Compliance with 10 CFR Part 50, Appendix I," U.S. Nuclear Regulatory Commission Regulatory Guide 1.109 (October 1977).

D30. J. W. Healy, "Review of Resuspension Models," in "Tranuranic Elements in the Environment," W. C. Hanson, ed., U.S. Department of Energy report DOE/TIC-22800, pp. 209-235 (1980). 
D31. G. R. Hoenes and J. K. Soldat, “Age Specific Radiation Dose Commitment Factors for a OneYear Chronic Intake," U.S. Nuclear Regulatory Cominission repoit NUREG-0172 (November 1977).
D32. G. G. Killough, D. E. Dunning, Jr., S. R. Bernard, and J. C. Pleasant, "Estimates of Internal Dose Equivalent to 22 Target Organs fo: Radionuclides Occurring in Routine Releases from Nuclear Fuel Cycle Facilities," Vol. I, Oak Ridge National Laboratory report NUREG/CR-0150, ORNL/NUREG/TM-190 (June 1978). 


\section{APPENDIX E}

\section{SOURCES AND EVALUATION OF RADIATION EXPOSURES}

\section{INTRODUCTION}

This appendix provides additional background on some of the technical aspects of radiation and its effects. It will familiarize the interested reade: with the concepts and terminology used in the evaluations presented in the main body of this report and other appendixes. It is not comprehensive in that other concepts and terminology applicable to other circumstances are not included. A short bibliography is included at the end for those desiring to read further.

\section{RADIATION}

Radiation is the transmission of energy through space. There are many kinds of radiation including visible light, microwaves, radio and radar waves, and $x$ rays. All of these are electromagnetic radiations because they consist of a combined electrical and a magnetic impulse traveling through space. Much of this radiation is vital to us. For example, light is necessary so that we can see. These radiations can also be harmful: too much ultraviolet radiation from the sun can cause sunburn or even skin cancer on prolonged exposure. Energy can also be transmitted through space by particulate radiations by virtue of their motion. Some of the most common pariculate radiations include alpha particles, beta particles, and neutrons. The first two were given names of the first letters of the Greek alphabet by their discoverers as a convenient way of designating them. It turns out that the beta particle is an eiectron. The electron is the fundamental negative charge in all matter and is responsible for electric zurrents. However, beta particles are electrons moving at very high speeds, even approaching the speed of light. The other particulate radiations are also fundamental particles from atoms.

The class of radiation important to this report is ionizing radiation. Ionizing radiations are either waves or particles with sufficient energy to knock electrons out of the atoms or molecules in matter. This disruption is termed "ionization."

The simplest example is the ionization of a single atom. The nucleus, or ceriter of the atom, is composed of particles called protons and neutrons. The proton has a positive charge ad the neutron has no charge. Negatively charged particles called electrons orbit around the nucleus and are held in place by the attraction between the positive and negative charges. A simple analogy to this is the planets in orbit around the sun held in place by gravitational attraction. In a neutral atom there are exactly the same number of electrons as protons and the positive and negative charges are balanced. When ionizing radiation knocks an electron out of an atom, the atom is left with a positive charge, and the free electron is negatively charged. These two are referred to as an "ion pair." Ion pairs are chemically active and will react with neighboring atoms or molecules. The resulting chemical reactions are responsible for causing changes or damage to matter, including living tissue.

This brief description covers the basic concepts of radiation and its effects. The rest of the discussion will elaborate on particular aspects: the types and sources of ionizing radiation, the basic units for measuring energy deposited in matter by ionization, ways to estimate the amount of biological effect and its significance, and the nature of radiation standards.

\section{TYPES OF IONIZING RADIATION}

The most common types of ionizing radiation are $\mathrm{x}$ rays, gamma rays. alpha particles, beta particles, and neutrons.

\section{A. $\mathrm{X}$ and Gamma Radiation}

$X$ rays are pure energy having no mess. They are part of the electromagnetic spectrum, as are light and microwaves, but with much shorter wavelengths and, therefore, 
the ability to transmit larger amounts of energy. Gamma rays are identical to $x$ rays except that they originate in the nucleus of an atom, whereas $x$ rays are produced by interactions of electrons. An $\mathbf{x}$ or gamma ray, having no electrical charge to attract or repel it from the protons or electrons, can pass through the free space in many atoms and, hence, through relatively thick materials before interacting. The most likely interaction occurs when the $x$ or gamma ray encounters an electron. When this occurs, some or all of the energy of the $x$ or gamma ray will be transferred to the electron, which then will be ejected from the atom. The electron may have enough energy that it can, in turn, produce additionai ionizations in other atoms it passes through. The electron, once its energy is spent, becomes a free electron (an electron not directly arsociated with an atom) like those found in all n?atter.

\section{B. Alpha Radiation}

Alpha particles are made up of two neutrons and two protons. This combination is the same as the nucleus of a helium atom. Because of the two protons, with no negative electrons to balance their positive charge, the alpha particle is positively charged. Alpha particles transmit energy as kinetic energy, or the energy of motion. The faster they move, the more energy they carry.

The comparatively large size and the positive charge of an alpha particle mean that it interacts readily with electrons and will not slip through the spaces between the atoms easily. It causes many ionizations in a short distance of travel. Because each of these ionizations dissipates energy, the alpha particle travels only a very short distance. For example, most alpha particles will not pass through a piece of paper or the protective layer of a person's skin. However, if an alpha particle is produced by radioactive material inside the body, it may cause many ionizations in more sensitive tissue.

\section{Beta Radiation}

Beta particles are electrons moving at high speeds. They transmit energy as kinetic energy. High-energy electrons approach the speed of light. They have comparatively small mass and a negative charge, so their penetration through matter is intermediate between the alpha particle and the gamma ray. They produce fewer ionizations along their path than the alpha particle, but more than gamma radiation. They can be absorbed by a sheet of rigid plastic or a piece of plywood. However, they can pass through the protective outer layer of the skin and reach the more sensitive skin cells in lower layers. They can irradiate internal tissues if produced by radioactive materials inside the body.

\section{Neutrons}

Neutrons are the particles that, with protons, form the nuclei of atoms. When free from the nucleus, they can transmit energy as kinetic energy. There are two major types of neutrons, fast and slow. Fast neutrons are moving rapidly and, when they strike a nucleus of an atom, they will give up some of their energy. With heavy nuclei such as those of lead, little energy is lost because the neutron rebounds. However, with light nuclei, such as those of hydrogen (hydrogen has one proton with the same mass as a neutron), the neutron undergoes a "billiard ball" type of collision with considerable energy transferred to the proton. The proton then moves through surrounding matter, producing less ionization than an alphe particle but more than a beta particle.

Slow neutrons do not have enough energy to cause ionization. But, because they have no charge, they can penetrate into the nucleus of an atom. This disrupts the balance in the nucleus and can result in the emission of radiations that produce ionization in the surrounding matter. One example of this is the transmutation of certain atoms of uranium into atoms of plutonium.

\section{SOURCES OF RADIATION}

Radiation arises from radioactivity, both natural and manmade, cosmic sources, and radiation-producing machines. In this report, the sources of interest include cosmic radiation and natural radioactivity, which both contribute to normal background, and manmade or technologically enhanced radioactivity, which contribute radiation in addition to background. This report does not address the production of radiation by devices such as $\mathbf{x}$ ray machires or accelerators.

\section{A. Radioactivity}

The atoms of most familiar things are structurally the same as when they were formed and have little prospect of changing. Thus, most atoms of carbon in a tree or in our bodies will remain atoms of carbon. In time, an atom may change its association with other atoms in chemical 
reactions and become part of other compounds, but it will still be a carbon atom.

There is a class of atoms, however, which are not stable and will spontaneously emit radiation and change to another type of atom or element. These atoms are said to be radioactive.

Many radioactive atoms such as isotopes of uranium and radium, ${ }^{40} \mathrm{~K}$. (potassium-40), and ${ }^{14} \mathrm{C}$ (carbon-14) occur naturally. In the cases of potassium and carbon, only certain proportions of the naturally occurring elements are radioactive and are known as radioactive isotopes. (The radioactive isotopes have the same number of protons in the nucleus as do the stable isotopes and, therefore the same chemical properties. However, the radioactive isotopes have a different number of neutrons than the stable atoms. A particular radioactive isotope is symbolized by the letter symbol for the chemical element with a numerical superscript representing the total number of protons and neutrons in the nucleus. See Table E-I for the symbols and names of isotopes of concern in this report.)

Many radioactive atoms can also be "manmade" in the sense that ${ }^{137} \mathrm{Cs},{ }^{90} \mathrm{Sr}$, and radioactive is.jtopes of plutonium can be produced in large quantities during nuclear fission of uranium in a reactor. However, these isotopes are also produced during the normal spontaneous fissioning of uranium in nature. The difference is that in nature the reaction happens at a slow enough rate that the number of naturally produced radioactive atoms of cesium, strontium, and plutonium is small and dispersed. Other manmade radioactive elements produced in nuclear reactors or by accelerators are not normally present in nature.

Radioactive atoms attempt to achieve a more stable state by spontaneously decaying to alter the ratio of protons and neutrons in the nucleus toward a more stable condition.

Radioactive atoms decay at a characteristic rate dependent upon the degree of stability of the individual atom. The rate is characterized by a period of time called the half-life. In one half-life, one-half of the initial number of atoms decay. The amount of radiation emitted aiso decreases by one-half in the same period. In the next half life, the number of atoms and the amount of radiation will again decrease by one-half, down to one-quarter of the original amount. Half-lives are unique for each particular type of radioactive atom: that is, each isotope has its own half-life that cannut be changed by man. Half-lives for different radioactive materials range from a fraction of a second to billions of years. In fact, some are so long that certain radioactive materials made at the time of the formation of the universe are still around. Examples include some isotopes of thorium and uranium.

When an atom decays, radiation may be emitted from the nucleus as alpha particles, beta particles, neutrons, or gamma rays. This changes the character of the nucleus, and the atom changes to an atom of a new element. (One particular type of decay, known as fission, results in the production of two new atoms.) Each type of radioactive atom decays with emission of characteristic types of radiation, each carrying specific amounts of energy. For example, natural ${ }^{234} \mathrm{U}$ always emits alpha particles with energies of about 4.8 relative snergy units, and manmade ${ }^{239} \mathrm{Pu}$ emits alpha particles with energies of about 5.1 relative energy units. Other than the slight difference in the initial amount of energy, the alpha particles are indistinguishable.

Atoms resulting from radioactive decay are called "daughter" atoms, whereas the original atom is called the "parent" atom. In some cases, the daughter atom resulting from the decay of a radioactive atom is, itself, radioactive. For naturally occurring uranium and thorium, there may be a sequence of as many as 12-14 radioactive daughters before the original uranium or thorium atom finally reaches stability as an atom of lead.

Table E-I lists the radioactive materials of primary importance to this report giving the half-lives and the principal types of radiation they enit during decay.

\section{B. Cosmic Radiation}

The high-energy radiations that enter the earth's atmosphere from outer space are known as primary , smic rays. The origin of primary cosmic rays is suil not completely determined, but must of the observe $\rfloor$ radiation originates in our galaxy. Some is produced by solar flares. Primary galactic cosmic rays are largely highenergy protons. Primary solar cosmic rays have relatively low energy and have little effect at the earth's surface.

When primary cosmic ray particles enter the atmosphere, a complex variety of reactions occur, especially with oxygen and nitrogen nuclei. These reactions result in the continuous production of radioactive elements including tritium, ${ }^{7} \mathrm{Be},{ }^{14} \mathrm{C}$, and ${ }^{22} \mathrm{Na}$ among many others. The reactions also result in the producuoi of neutron and beta particle radiation, referred to as secondary cosmic radiation. The amount of radioactivity 
TABLE E-I

\section{RADIOACTIVE MATERIALS OF PRIMARY INTEREST IN THE RADIOLOGICAL SURVEY}

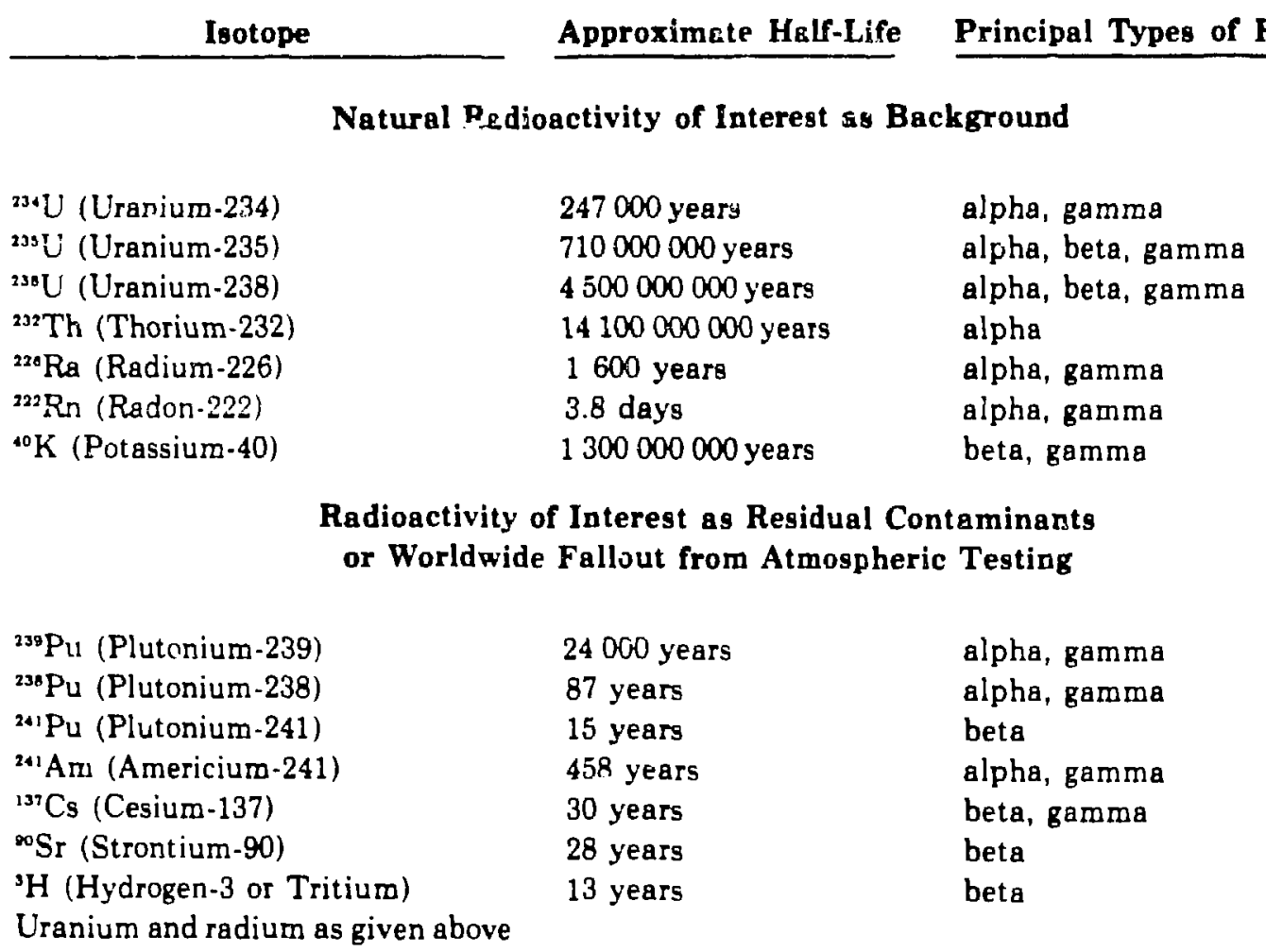

and radiation from cosmic rays increases significantly with altitude above sea level because of the decreasing thickness of the atmosphere. The influence of the earth's magnetic field results in more cosmic radiation in polar latitudes responsible for the so-called northern and southern lights.

\section{Y. UNITS FOR RADIATION AND RADIOAC- TIVITY}

Units to quantify radiation or radioactivity provide for uniformity in measurements or comparisons and permit the establishment of standards specifying the amount of radiation allowable under various circumstances. Radiation units may initially seem obscure and difficult to understand. However, as in the case of the pound or kilogram, familiarity with the units makes them understandable and useful.

\section{A. Radiation Units}

The basic unit for measuring radiation is the rad. It is the amount of radiation that deposits a specified amount of energy by ionization in each gram of material (about $1 / 28$ of an ounce). The amount of energy released in the material is small; it increases the temperature of the gram of material by a few billionths of a degree. However, it is not the amount of heat liberated or the temperature rise that is important. Rather, it is the ionization that induces cnemical changes. The rad applies to all radiations and all materials that absorb the radiation. 
The most commonly used radiation unit is the rem. The rem quantifies the biological response to radiation rather than the amount of energy delivered to the tissue. To understand this, remember that different types of radiation produce ionizations at different rates as they pass through tissue. The alpha particle travels only a short distance, causing intense closely spaced ionization along its track. The beta particle travels much iarther, causing much less ionization in each portion of its track. Therefore, the alpha particle is more damaging to tissue than the beta particle for the same number of ionizations because the damage to cells in the tissue is localized. The biological effectiveness of the alpha particle is greater than that of the beta particle for the same total amount (rads) of energy deposited, and this difference is accounted for by the use of appropriate factors. In general, the factors used are 1 for $\mathrm{x}$ or gamma radiations and most beta particles, 5 to 10 for neutrons, and 10 to 20 for alpha particles. The rem is defined as the amount of radiation (in rads) from a given type of radiation multiplied by the factor appropriate for that type of radiation to approximate the biological damage that it causes. Thus, 1 rad of energy from gamma rays would result in 1 rem, and 1 rad from alpha particles would result in 10 to 20 rem of dose. Because the approximate relative degree of damage from each of the types of radiation is known, the rem can be used to estimate the approximate biological effect. Within these limits of uncertainty, the rem permits evaluation of potential effects without regard to the type of radiation or its source. One rem of exposure from natural cosmic radiation results in the same biological consequences as $1 \mathrm{rem}$ from medical $x$ rays or $1 \mathrm{rem}$ from radiation produced by decay of either natural or manmade radioactivity.

A frequent source of confusion encountered in the use of radiation units is their application to a standard weight of tissue, rather than all of the tissue irradiated. Thus, a person can receive 1 rad or 1 rem of radiation from an $x$ ray of the teeth, where little tissue is irradiated; from a chest $\mathrm{x}$ ray, where a moderate amount of tissue is irradiated; or from full-body radiation, where all tissue in the body is irradiated. Although these are all 1 rem of radiation, the effects will be different depending upon the organs involved. Thus, one must always keep in mind the portion of the body or organs involved and make comparisons only for corresponding exposures. In this report, radiation doses were evaluated for the whole body, for the lungs, and for bone. Whole-body doses must be com- pared only with other whole-body doses or to whole-body dose standards, and so on.

Because many of the radiation doses discussed in this report were small, the metric prefixes milli for "onethousandth" ( $1 / 1000$ or 0.001 , symbolized as "m") or as micro for "one-millionth" (1/1000 000 or 0.000001 , symbolized " $\mu$ ") were often used. One million microrem $(\mu \mathrm{rem})=1000$ millirem $(\mathrm{mrem})=1 \mathrm{rem}$. Millirems are used exclusively in the rest of this appendix to simplify comparisons.

In $:$ : me cases, radiation measurements are expressed as a dose rate, or the amount of radiation received in a unit of time. For example, some instrument measurements of background are reported in "microrem per hour" or $\mu \mathrm{rem} / \mathrm{h}$. To get total dose, the rate is multiplicd by the time of exposure. This is conceptually similar to multiplying speed (rate of travel, say in miles per hour) by time to get total distance travelled.

Dose or dose rate may be expressed using rads or rems, depending on whether the reference is to energy deposited or to biological effect.

\section{B. Radioactivity Units}

The basic unit for meisuring the amount of radioactivity or quantity of radioactive material is the curie, named in honor of Madame Curie. The curie ( $\mathrm{Ci}$ ) is the amount of radioactive material in which $37000000000(\mathrm{i} ;$ billion) atoms are decaying each second. This apparently peculiar number is the approximate number of atoms decaying each second in 1 gram of pure radium, the element discovered by Madame Curie. The mass of material in a curie varies from one isotope to another. The different half-lives of each radioactive material are the main cause for this variation. For materials with short half-lives, a large fraction of the atoms present are decaying in any given second, and the weight of 1 curie is small. For radioactive materials with long half-lives, the weight of 1 curie will be large. For example, the weight of 1 curie of naturally occurring ${ }^{40} \mathrm{~K}$ is about 310 pounds, or about 140000 times as much as 1 curie of radium.

The curie is a relatively large quantity of radioactivity for most purposes of this report. Accordingly, the metric prefixes are used to indicate units in fractional parts of a curie, such as microcurie or picocurie. The units used most often in the report are summarized in Table E-II. 
TABLE E-II

\section{UNITS OF RADIOACTIVITY USED IN THE RADIOLOGICAL SURVEY}

\begin{tabular}{|c|c|c|c|}
\hline Unit & Abbreviation & $\begin{array}{c}\text { Disintegrations } \\
\text { per Second }\end{array}$ & $\begin{array}{c}\text { Equivglent Value in } \\
\text { Other Time Units }\end{array}$ \\
\hline curie & $\mathrm{Ci}$ & 37000000000 & $\cdots$ \\
\hline millicurie & $\mathrm{mCi}$ & 37000000 & $\cdots$ \\
\hline microcurie & $\mu \mathrm{Ci}$ & 37000 & $-\cdots$ \\
\hline picocurie & $\mathrm{pCi}$ & 0.037 & 2.22 per minute \\
\hline attocurie & $\mathrm{aCi}$ & 0.000000037 & 1.2 per yoar \\
\hline
\end{tabular}

The text often discusses radioactivity in environmental media, such as air or soil. In these cases, radioactivity is reported as a concentration, or the amount of radioactivity in or associated with a certain amount of air or soil. Much of the information on radioactivity in soils is reported as picocuries per gram ( $\mathrm{pCi} / \mathrm{g}$ ) of some particular radioactive isotope. This means that there are a certain number of picocuries of the isotope associated with each gram (454 grams $=1$ pound) of soil. For example, a value of $1 \mathrm{pCi} / \mathrm{g}$ means that each gram of soi! has an associated radioactivity of about 2.2 decays each minute. Concentrations of radioactivity in air are generally reported as attocuries per cubic meter $\left(\mathrm{aCi} / \mathrm{rn}^{3}\right)$. This means that there are a certain number of attocuries of a radioactive isotope dispersed throughout the volume of air equivalent to a cube 1 meter on each side $(1$ meter = 1.09 yards). For example, a value of $3 \mathrm{aCi} / \mathrm{m}^{3}$ would mean that a cubic meter of air z:atains radioactivity of about 3.6 decays in a year.

\section{DETERMINING HOW MUCH RADIATION IS RECEIVED}

Radiation doses can be received from sources external to the body, such as cosmic radiation or radiation produced by radioactivity in the earth. Radiation doses can also be received from radiation produced by radioactivity taken into the body by inhalation or ingestion. These two modes of exposure are important in this study in terms of both normal doses from background radiation or radioactivity and incremental doses attritutable to residual contaminants.
The important distinction between radiation and radioactivity must be emphasized at this time to avoid confusion. When radiation interacts with a person's body, it is quickly dissipated as ionization and eventually heat. However, radioactive materials can enter a person's body and remain there for some period of time, ef i: ng radiation. Thus, it is incorrect to say that there is "radiation in a person's body." It is correct to say the person has radioactive materials in his body and radiation is emitted from these radioactive materials.

\section{A. External Penetrating Radiation}

Normal external penetrating radiation doses come primarily from natural terrestrial sources or natural cosmic snurces. These doses affect the entire body, including all internal organs.

1. Natural Terrestrial Sources. The radioactivity in rocks, soils, and other natural materials arises primarily from three sources: uranium and its daughters (such as radium), thorium and its daughters, and potassium. There are many other natural radioactive materials, but their contributions to human dose are small. The amount of samma radiation from these sources varies in different part, of the country depending upon the amounts of natural radioactivity in the soil. The average for the coastal plain is about 15 mrem per year; for the noncoastal plain, excluding the Colorado plateau area, it is about 30 mrem per year; and for the Colorado plateau area, it is about 60 mrem per year. There are, however, variations within these averages, with higher values in 
given localities. For example, radiation up to 100 mrem per year from soils and rocks has been measured in central Florida and in the granitic regions of New England. In India and Brazil, terrest sà radiation reaches several hundred mrem per year over large regions and even higher values in smaller parts of these regions.

Measurements in the Los Alamos, New Mexico, area indicate an average of about $57 \mathrm{mrem}$ per year from natural terrestrial sources. Because of the variety of geologic formations in the area, the range is from about 30 to 90 mrem per year. Thus, the average is about $40 \%$ higher than for the U.S., as a whole, but the range is less than for the U.S.

The same natural radioactive materials, especially uranium and thorium, are responsible for penetrating radiation doses from masonry structures. A United $\mathrm{Na}$ tions study reports that doses average about $30 \%$ higher inside masonry siructures than outdoors. Conversely, structures of wood or metai materials afford some shielding and may reduce induor doses from natural terrestrial radioctivity by $25 \%$ compared with outdoor doses.

2. Natural Cosmic Sources. As previously discussed, cosmic radiation arises primarily from space outside of our solar system. The atmosphere provides some shielding, but there is a definite increase in cosmic ray intensity as one goes to higher altitudes. At sea level, cosmic rays, including cosmic neutrons, produce about 30 mrem a year. At the altitude of Denver, Coiorado ( $5000 \mathrm{ft}$ ), they produce about 55 mrem per year, and at Leadville, Colorado ( $10090 \mathrm{ft}$ ), they produce about 120 mrem per year.

Airline travel at higher altitudes can result in doses of 0.2 to 0.3 mrem $T^{-}$hour or 1.5 to 2 mrem total for a single transcontinental trip.

3. Medical Diagnostic X Rays and Other Manmade Radiation. People receive manmade radiation from a number of sources. By far, the most important are medical procedures, including diagnostic $x$ rays and the medical use of radioact isotopes. The average annual whole-body dose to a resident of the U.S. from diagnostic medical procedures is estimated at 70 to 90 mrem per year, or an amount about equal to normal background radiation.

Otrier sources of manmade or man-enhanced radiation, including television, smoke detectors, luminous-dial watches, mining and milling of phosphate, and burning coal and natural gas, add 2 to 5 mrem per year.

\section{B. Radiation from Internally Deposited Radioactivity}

Many radioactive materials, both natural and manmade, can be incorporated into tissues because their chemical properties are identical or similar to those of isotopes in the tissues. For example, $0.012 \%$ of uatural potassium is the radioactive isotope ${ }^{40} \mathrm{~K}$. The radioactive portion of potassium is incorporated into plant and animal tissues in the same manner as the stable potassium isotopes because the chemical properties are identical. Radioactive ${ }^{90} \mathrm{Sr}$, which results from nuclear fission, can be incorporated in tissues because its chemical behavior is similar to that of calcium. Once such radioactive isotopes are deposited in biological tissue, they emit radiation that results in an internal dose to the organ or organism. An important point is that internally deposited alpha emitters can be significant because the alpha particle radiation is emitted directly into tissue, whereas external alpha particle radiation is stopped by the outermost skin layers.

i. Pathways. Although radiation from internally deposited radioactive materials may cause the same ultimate effects as external penetrating radiation, the evaluation is more complex. This is because the physical and chemical processes that govern movements of the materials in nature and biological systenıs must be considered. The evaluation of movements of materials by such processes as dispersion in the atmosphere, transport in water, uptake in plants or animals, and ultimately, the biochemistry of the human body is often termed pathway analysis. There is nothing unique to pathway analysis of radioactive materials; the methods and principles are equally applicable to movements of natural substances and nonradioactive pollutants.

The major types of environmental pathway analyses considered in the radiological survey were resuspension, hydrologic transport, and food chains. These are all ways of transporting contaminants to the human body.

Resuspension encompasses various mechanisms, such as wind or mechanical disturbance, for making particles of dust and soil airborne. Once airborne, the particles and any contaminants on them are potentially available for inhalation. 
Hydrologic transport encompasses movement of materials dissolved in water and movement of materials attached to sediments. Such movements can make contaminants available for ingestion with drinking water and uptake in plants or animals or can redistribute sediments to different locations.

Food chains encompass the movement of materials through natural biological systems. A typical sequence starts with plants taking up materials from soil or water during natural plant growth or gardening. The text step could be ingestion of plant materials by cattle or fish, followed by ingestinn of beef or fish by humans.

Once environmental pathways have made materials available for entry into the human body, the analysis must determine how the substances of concern will be assimilated within the body. This requires an understanding of the complex biochemistry of the body to determine where particular substances will be deposited and how long they will be retained. For example, both strontium and plutonium can ultimately be preferentially deposited in bone and are then retained for long periods. However, the amount deposited depends strongly on the chemical form of the element and whether the materials gain entry by inhalation or ingestion. For the same amounts of radioactivity, strontium is deposited to a greater degree when ingested, and plutonium is deposited to a greater degree when inhaled.

Internally deposited radioactivity gives off radiation and thereby produces doses as long as it is in the body. Accordingly, doses delivered must be accounted for over a period of time beyond the period during which the radioactivity was ingested or inhaled.

The 50-year dose commitments represent the total dose accumulated in the body or specific organs over a 50 year period because of ingestion or inhalation of radioactivity during the first year. The 50-year commitments are always as large as or larger than first-year doses. In this summary, only the 50-year commitments are compared with the standards.

Conceptually, this is in agreement with the recommendations of the International Commission on Radiological Protection (ICRP), and, in effect, for regulatory purposes charges the entire dose commitment against the year in which exposure occurs. The use of the 50-year dose commitment also permits making estimates of risk over a lifetime from the given exposure and simplifies comparisons between different exposure situations.

The dose commitments were calculated using published factors from references currently used in regula- tion. The mathematical dose models employed in the derivation of these factors were based primarily upon recommendations of the International Commission on Radiological Protection.

Other methods of computing doses are available, and some are considered more up-to-date in terms of utilizing the best current understanding of the behavior of isotopes within the body. Additionally, there are conceptually different approaches that emphasize the dose at the time of maximum dose rate following exposure as the basis for comparison with standards. This is significant for isotopes such as plutonium that accumulate in certain parts of the body and can lead to a constantly increasing dose rate under conditions of chronic exposure. One such approach has been proposed by the EPA as guidance for Federal agencies in regard to plutonium.

These other approaches do not result in dose estimates or comparisons with standards for the radionuclides of concern sufficiently different from the methods used in this report to make any significant difference in the conclusions drawn. For example, under conditions of chronic exposure to airborne ${ }^{239} \mathrm{Pu}$, the dose in the year of maximum dose rate (taken to be the 70th year) calculated by alternate methods gave estimates ranging from about 1.4 (for bone) to 2.6 (for lung) times the 50 -year dose commitment. These differences are of about the same magnitude as other uncertainties in field data and are smaller than some of the intentionally overestimated assumptions incorporated into these evaluation. Thus, there would be no significant changes in the relative ranking or general magnitude of estimated doses and risks if other methodologies were used.

2. Ratiation from Natural Radioactivity. The most prominant internal natural radioactive material in the body is a radioactive isotope of potassium. Potassium- 40 is distributed throughout the body and contributes about 17 mrem per year to the whole body. Other natural radioactivity taken in with food or air adds enough radiation to bring the total whole-body dose to about 27 mrem per year.

Some natural radioactive materials tend to concentrate in particular parts of the body. For example, radium and its daughters concentrate in bone and contribute a major part of the approximately 47-mrem-per-year bone dose.

Radon, a natural radioactive gas given off by all terrestrial materials including soil and masonry products, is the largest contributor to internal lung doses. Radon is inhaled with air and decays by alpha-particle radiation 
through a chain of other radioactive daughters that contribute doses as they, in turn, decay. Concentrations of natural radon in the air can be greatly increased in r.asonry structures or in tightly sealed structures where dilution by ventilation air exchange is low.

3. Radiation from Worldwide Fallout Radioactivity. Radioactive materials released by atmospheric nuclear weapons testing have been dispersed worldwide and deposited on soils everywhere. By various pathways, including resuspension and food chains, small amounts of such radioactivity are incorporated into every human body. The average dose from worldwide fallout radioactivity to the population in the U.S. for the whole body is about 4.4 mrem a year. For lungs and bones, the doses are less than $1 \%$ of doses from natural materials.

\section{POTENTIAL HARM OR RISK FROM RADIA- TION}

The damage done by radiation results from the way it affects molecules essential to the normal function of body cells. Four things may happen when radiation strikes a cell.

1. It may pass through the cell without doing any damage.

2. It may damage the cell, but the cell partially repairs the damage. (The ability of a cell to repair some of the damage from radiation explains why a given dose of radiation delivered in small amounts over a long period of time is generally believed to be less damaging than the same total dose given all at once.)

3. It may damage the cell so that the cell fails to repair itself and reproduces in damaged form over a period of years.

\section{It may kill the cell.}

The death of a sirigle cell may not be harmful, but serious problems occur if so many cells are killed in a particular organ that the organ no longer can function properly. Incompletely or incorrectly repaired cells may, over a period of time, jroduce delayed health effects such as cancer, genetic mutations, or birth defects.

Radiation at high enough doses will kill in a short time. The lethal dose is estiniated to be 400000 to 500000 mrem for gamma radiation with death occurring in 10-3C days. However, the p'sblic is seldom, if ever, subjected to such high doses. We will, therefore, concentrate our attention on the effects that occur later, cancer and genetic effects.

\section{A. Cancer}

Information en the induction of cancer in humans arises from several sources. The most important data on external radiation are for the Japanese who survived the blast effects but received radiation at Hiroshima and Nagasaki and for the people who were exposed to radiation during medical therapy. Information on internal emitters comes from the radium dial painters who ingested radium while painting dials in the early 1920s, from a group of patients who were administered radium as a tonic, and from uranium miners who were exposed to radon and its daughter products. Evaluations of such data have led to estimates of the likelihood of radiationinduced cancer. These estimates are accepted by the vast majority of scientists working nationally and internationally with radiation.

Before discussing the actial risks, there are several points that are fundamental in interpreting the values. First, cancers or genetic changes caused by radiation cannot be distinguished from those that are occurring every day spontaneously or caused by other carcinogenic chemicals. A bout 400000 deaths occur from cancers in the U.S. each year, or about 15 to 20 per 10000 people. We can infer an effect from radiation only if the total n"mber of cancers (or of a particular type of cancer) is ir creased oy an amount we can detect. Valid comparisons are made even more difficult because some population groups have lígher normal rates of cancer than others. This may be tue to differences in the way they live and the possible carcinogens in their environment. Cancer also occurs more often in older people than in younger people. Thus, to detect increases in effects, a comparison (or control) group that is the same as the exposed group is necessary.

This all leads to the fact that there have been no direct measurements of increased cancer for low-level radiation exposures (1000-5000 mrem). Data exist only for much higher exposures $(100000 \mathrm{mrem}$ and above delivered in a short time). Thus, scientists have estimated risks for the lower doses by assuming that any dose results in some effect (no threshold for effect) and that the relation between the sliation dose and the effect (cancer) is linear. That is, for each doubling of the dose there will be 
a doubling of the effect. This is an assumption that is generally believed to provide an overestimate of any effects. In fact, many scientists are now using a more complex mathematical relation between dose and effect that estimates risks at 2 to 10 times lower than the values given in this report.

Second, another characteristic of cancer or genetic effects from any cause is that they are statistical in nature. That is, not all of the individuals will be affected. Rather, a few individuals in the population will get cancer or have genetic defects and the remainder will not be affected. Thsrefore, we express the risk as the iikely number of effects in a given population. For example, 30 cancers per million people means we expect 30 cancers out of this group of 1000000 people, but cannot tell which of the 30 will get cancer. Or, this example could also be stated that an average individual in that population has a risk of cancer of 30 chances in a million.

Cancers of many types can result from radiation or other carcinogens. These cancers do not occur for some period of time after exposure, usually 5 to 25 years. This period of time is called the latent period. For example, there is information from the Japanese survivors that the latent period for the first leukemia to appear is 1 to 4 years. The risk of leukemia is limited to about 25 years after the exposure. After this time, the risk of leukemia goes down to the normal incidence. For other cancers, the latent period is longe $i$, about 10 to 20 years. However, information is incomplete.

Estimates have been made of the number of cancers that could result from a given radiation exposure, using the data for humans. These estimates generally are considered to be high because of the use of the linear, nothreshold assumption in extrapolating from the high levels at which people actually were exposed. In spite of this, these estimates are useful for illustrating the amount of additional cancer that could be induced in a population exposed to radiation (or conversely, the chance that an individual exposed to radiation will get cancer).

The estimates of health effects risks given in this report were based on the factors recommended by the National Academy of Science and the International Commission on Radiological Protection. Multiplying an estimated dose by the appropriate risk factor gives an estimate of the probability of injury to the individual as a result of that exposure. The risk factors used are

For uniform whole-body dose

Cancer mortality

0.0000001 per mrem whole body,
For specific organ doses

Lung cancer

0.0000002 per mrem

to lung,

Bone cancer

0.000000005 per

mrem to bone.

As an example, a whole-body dose of 10 mrem per year would be estimated to add a risk of cancer mortal y to the exposed individual of one chance in is million $(1 / 1000000)$ per year of exposure.

Such risk estimates must be placed in appropriate contexts to be useful as a decision-making tool. A useful comparison is an estimate of the risk that can be attributed to natural background radiation. Radiation from various natural external and internal sources results in exactly the same types of interactions with body tissues as that from so-called "manmade" radioactivity. Thus, the risks from a given dose are the same regardless of the source.

Natural background radiation for people in the Los Alamos, New Mexico, area consists of the external penetrating dose from cosmic and terrestrial sources, cosmic neutron radiation, and self-irradiation from natural isotopes in the body. These sources give a combined whole-body dose averaging about $158 \mathrm{mrem}$ per year. This can be interpreted using the ICRP risk factors to represent a contribution to the risk of cancer mortality of 15 chances in a million for each year of exposure or a risk of 8 chances in 10000 for 50 years of exposure to natural background radiation. As perspective, the overall U.S. population lifetime risk of mortality fro: cancer induced by all causes is currently estimated at abeut 2 chances in 10 .

\section{B. Genetic Effects}

One of the concerns of many people is the possible effect of their exposure to radiation on future children. An effect on the reproductive cells of the body that can be inherited by children is called a genetic effect and the change itself is called a mutation. Many of these mutations are unnoticeable or barely noticeable.

There is no information based on human exposure that will allow an estimate of the risk of mutations. Thus, data from animals such as fruit flies and mice, along with known abnormalities in human births and general knowledge of genetics, have been used to arrive at an estimate of the risks. Careful study of the survivors of the Hiroshima and Nagasaki bombs and their descendents 
has shown that these estimates are reasonable. The information available is not sufficient to provide a precise estimate, but a range of values will illustrate the magnitude of the risk.

About $10 \%$ of all births are estimated tc have some form of genetic mutation. These range in importance from the trivial, such as a change in eye color, to the serious, such as a stillbirth or a deformity in the body of the child. Exposure to 1000 mrem of radiation during the childbearing years is estimated to result in 6 to 100 additional changes per million births in the first generation. This may be compared with the 100000 estimated to occur in the same group without above-background radiation. Continued exposure to $1000 \mathrm{mrem}$ for generation after generation is estimated to evertually lead to 10 to 150 additional births with genetic mutations per million births. If the actual radiation received is higher or lower, the numbers given above will change in proportion.

\section{Effects on the Fetus}

You will often see signs in the $\mathrm{x}$-ray departments of hospitals asking women to see the doctor if they have reason to believe they are pregnant. The reason is that the fetus, particularly in the first three months, is especially sensitive to radiation and may be damaged if exposed to excessive radiation. The doctor, therefore, may wish to re-evaluate his procedure.

Animal iniormation on single exposures to radiation indicates that some changes detectable by sophisticated tests have occurred with a few rems. At present, no specific relationship between dose and the likelihood of damage has been developed. Because of this and the relatively low doses attributable to residual contaminants, no estimates of effects were made in this report.

\section{STANDARDS FOR EXPOSURE TO RADIA- TION}

There are a number of organizations that provide standards or regulations governing the amount of radiation people should receive. Voluntary standards, or recommendations, are provided by the International Commission on Radiological Protection (ICRP) and the U.S. National Council on Radiation Protection and Measurements (NCRP). These are both groups of scientists knowledgeable abont radiation who study the available data and recommend appropriate limitations on the maximum amount of exposure that should be received. They also make recommendations on appropriate equipment ant procodures. Their recommendations are nonbinding but have been accepted by many of the regulatory agencies.

The principal regulatory agencies in the U.S., which provide regulations on radiation exposure, are the Environmental Protection Agency (EPA) and the Nuclear Regulatory Commission (NRC). Other agencies that provide regulations in their own areas of interest include the Food and Drug Administration (FDA) and the Occupational Safety and Health Administration (OSHA).

The EPA is the lead agency in the sense that it provides basic guidance to be used by all Federal agencies. The EPA has the responsibility to provide general environmental standards for the Nuclear Regulatory Commission and specific responsibilities to produce standards under the Clean Air Act, the Clear Water Act, and the Resources Recovery and Conservation Act. The EPA has adopted a policy of setting standards at as low a level as is believed economically feasible. For this reason, the EPA standards are frequently lower than those from the ICRP or the NCRP.

The Nuclear Regulatory Commission provides regulations to cover nuclear reactors and all products associated with reactors, including the radioactive materials used for medicine. Because the Nuclear Regulatory Commission does not regulate natural radioactive materials or $\mathrm{x}$ rays, the states have taken responsibility, usually using the recommendations of the NCRP.

The standards and regulations, or guides, fall into twr general categories: (1) the primary radiation protection standards and (2) the seconcary standards for intake of radioactive materials. Within each category there are generally two sets of values, one applicable to occupationally exposed persons and the second applicable to members of the public. All comparisons in this report are made with the standards appropriate for the general public.

An important principle in all radiation protection recommendations and regulations is that the amount of radiation received by people should be kept as far below the actual dose limit as is reasonably achievable. That is, the goal of a radiation protection program is not to see that everyone is kept at or just below the limits; instead, the goal is to see that working conditions and practices 
are such that both the workers and the public receive the smallest amount of radiation that can practically be achieved.

\section{A. Primary Radiation Protection Standards}

Primary radiation protection standards give limits for total exposure to external and internal radiation for the whole body or for specific organs. The standards, or upper limits, for the public are basically one-tenth of the values permitted for occupationally exposed workers. The standards apply to increments of exposure in addition to natural background and in addition to medical exposures.

The upper limit adopted by all Federal agencies, including the Department of Energy, for whole-body radiation to an individual member of the public is 500 millirem per year. For average radiation doses to an exposed population, the Federal Radiation Council (which has been incorporated into the EPA) recommended that the average exposure to that portion of the population receiving the highest annual dose be limited to 170 millirem in addition to natural or medical radiation exposure. (This average limit was set to minimize potential genetic damage and was derived from a limit of 5000 millirem over 30 years fo: large populations.)

The basic radiation standards as used by the Depart ment of Energy are shown in Table E-III. These include both whole-body limits and specific organ limits. The EPA has proposed Federal guidance for exposure to transuranium elements, also shown in Table E-III.

A final word about these standards and their meaning is appropriate. Exposure to more radiation than permitted by the standards is not analogous to stepping off a cliff. That is, there is no sharp line between doses causing excessive harm and doses causing little or no harm. The opposite situation is true for many chemical poisons. An additional exposure of 1 millirem increases a person's risk to cancer or genetic muration by the same amount whether it is a millirem of background radiation, the first millirem above background radiation, or the first millirem above the 500 millirem limit.

All of the doses evaluated in this radiological survey under current conditions of land use were small fractions of those permitted above natural background and medical exposure by the DOE Radiation Protection Standards. The highest dose, from the unlikely cirsumstance of a full-year occupancy of a small portion of the former waste treatment plant site, was estimated at about
$12 \%$ of the standard. All other doses were less than $2 \%$ of the standard.

For projected possible land use conditions, the maximum dose estimates were for hypothetical home gardeners in one of the canyon areas (about $1.5 \%$ of the standard) and construction workers (about $6 \%$ of the standard). Continuous exposure to resuspended dust in the canyons was estimated to result in less than $1.3 \%$ of the EPA proposed guidance for persons exposed to transuranium elements in the general environment.

The various doses evaluated are summarized in Chapter 1 and described more completely in Chapter 5 , Sections II and III.

\section{B. Secondary Standards for Intake of Radioactive Materials}

Secondary standards to be used in control of exposure by limiting the intake of radioactive materials are calculated from the primary standards using knowledge of the fate of the particular radioactive material in the body and the time it remains in individual organs. These standards are estimated for ingestion of water and inhalation of air. They are expressed as concentrations and are generally calculated so that the doses received from internal radioactivity will not exceed the primary standard under conditions of continuous exposure to the contaminants in air or water.

The assumption of continuous inhalation of air or ingestion of water, upon which the secondary limits are based, leads to a problem in their use. A frequent misinterpretation is that the secondary standards represent maximum concentrations to which a person can be exposed regardless of the time of exposure. This is rot true. The total intake of radioactivity determines the dose received, not the particular concentration in air or water at any given time. The secondary standards are calculated as annual averages. Thus, a person could be exposed to 10 times the secondary standard concentration for a week and receive only about $20 \%$ of the annual intake permitted by the secondary standard.

The secondary standards account for the fact that some radioactive materials have a short half-life or are rapidly eliminated from the body. Tritilim is eliminated from the body with a half-life of 12 to 1. days. Thus, the radiation received from a single drink at the secondary limit will be only a fraction of the annual limit that is calculated for continuous intake. Another example, plutonium, which is very well retained in the body and has a 
TABLE E-II

STANDARDS AND GUIDES FOR RADIATION AND RADIOACTIVITY

\title{
DOE Radiation Protection Standarda for \\ External and Internal Exposures
}

\author{
Individuals and Population Groups
}

in Uncontrolled Ares.

\begin{tabular}{|c|c|c|c|}
\hline \multirow[b]{2}{*}{ Type of Exposure } & \multicolumn{3}{|c|}{$\begin{array}{c}\text { Annual Dose Equivalent or } \\
\text { Dose Commitnent }\end{array}$} \\
\hline & \multicolumn{2}{|c|}{$\begin{array}{c}\text { Based on Dose to } \\
\text { Individuals at Points of } \\
\text { Maximum Probable Exposure }\end{array}$} & $\begin{array}{l}\text { Bused on an Average } \\
\text { Dose to a Suit able Sample } \\
\text { of the Exposed Population }\end{array}$ \\
\hline Whole body, gonads, or bone marrow & \multicolumn{2}{|c|}{$\begin{array}{l}0.5 \mathrm{rem} \\
\text { (or } 500 \mathrm{mrem} \text { ) }\end{array}$} & $\begin{array}{l}0.17 \text { rem } \\
\text { (or } 170 \mathrm{mrem} \text { ) }\end{array}$ \\
\hline Other organs & \multicolumn{2}{|c|}{$\begin{array}{l}1.5 \text { rem } \\
\text { (or } 1500 \text { mrem) }\end{array}$} & $\begin{array}{l}0.5 \mathrm{mrem} \\
\text { (or } 500 \mathrm{mrem} \text { ) }\end{array}$ \\
\hline \multicolumn{4}{|c|}{$\begin{array}{l}\text { EPA Maximum Contaminant Levele from Natural } \\
\text { Interim Primary Drinking Water Regulation }\end{array}$} \\
\hline \multicolumn{2}{|c|}{ Isotope } & \multicolumn{2}{|c|}{ Concentration } \\
\hline \multicolumn{2}{|c|}{$\begin{array}{l}\text { Gross Alpha } \\
\text { (including }{ }^{\text {stRa but }} \\
\text { excluding radon and uranium) }\end{array}$} & Water & \\
\hline
\end{tabular}

long half-life, will reach the annual radiation linit only after continuous inhalation or ingestion at the secondary limits for 50 years. Thus, intake at or above this limit for days, weeks, or even months will not result in reacning or even approaching the primary standard dose limit.

The secondary standards are usually stated as concentrations of radioactivity in air or in water, as defined in Section V.B of this Appendix. The values used for comparison in this report are presented in Table E-III. The DOE secondary standards are called Concentration
Guides. The EPA secondary standards for drinking water are called Maximum Contaminant Levels, and for airborne transuranics are called Derived Air Concentrations. None of the relevant secondary standards was exceeded by any measured or theoretically estimated concentrations. Evaluations in the radiological survey were carried through to estimates of doses to permit comparison with the primary standards. Accordingly, no emphasis was placed on comparisons with the secondary standards. 


\section{BIBLIOGRAPIYY}

Natural and Background Radiation in the U.S.

D. T. Oakley, "Natural Radiation Exposure in the United States," U.S. Environmental Protection Agency report ORP/SID 721 (June 1972).

A. W. Klement, Jr., C. R. Miller, R. P. Mirix, and B. Shieien, "Estimates of lonizing Radiation Doses in the Jnited States 1960-2000," U.S. Environmental Protection Agency report ORP/CSD 72-1 (August 1972).

National Council on Radiation Protection and Measurements, "Natural Background Radiation in the United States." NCRP report No. 45 (November 1975).
Scurces and Effects of $\mathbf{P}$ idiation

United Nations Scientific Committee on the Efferts of Atomic Radiacion, "Sources and Effects of Ionizing Radiation, 1977 Repcrt to the General Assembly," United Nations Publication E.77.IX.1 (1977).

M. Eisenbud, Environmental Radioactrvity, 2nd ed. (Academic Press, New York, 1973).

International Commission on Radiological Protection, Annals of the ICRP, Vol. 1, No. 3, ICRP Publication 26, Pergamon Press, New York (1977).

Committee on the Biological Effects of Ionizing Radiations, National Research Council, The Effects on Populations of Exposures to Low Levels of Ionizing Radiation: 1980, National Academy Press, Washington, D.C. (1980). 